Historic, Archive Document

Do not assume content reflects current scientific knowledge, policies, or practices. 

HARDY HERBACEOUS and

Aldine Plants

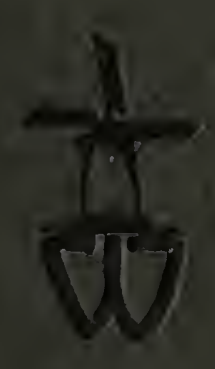

Whoteside Calatog
sumin. 1926

The WAYSIDE GARDENS CO MENTOR, OHIO

Simeriot's Grdarest Prochuburs of Hardy Pererinials 


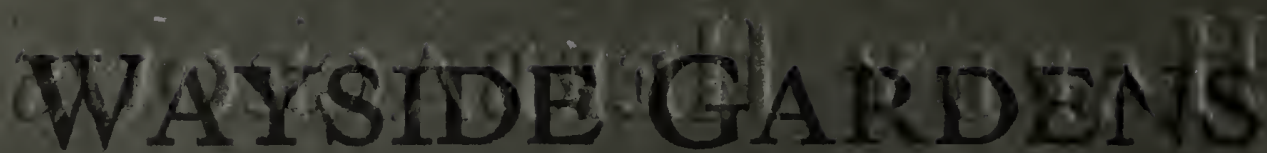 Mentor, Ohio}

Tel phone, Mentor 62-W

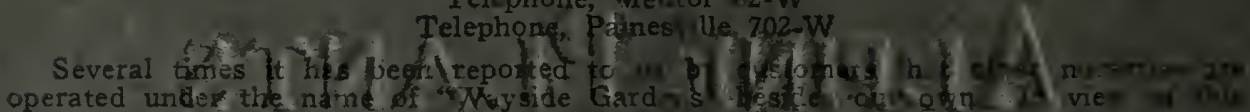
fact, we wish to state that we have no brarc is sid do not oper te an lic uweries except at Mentor, Ohio. We do not ha e iny age- representing at, ' $a$ ' inorder to obtain the best re aits our plants shou', le ordered fr m us du ct. $O$. plants, however, may be obtained through your local dealer. If order wo this manner, look for our label.

\section{READ CAREFULLY}

All of the stock offered $i$ grown on our orn knoths, that grown from fulling and divisions we know to be clean af drus. Plant srown from se ds se foor re stock obtained from the most reliabl- sources.

OUR PLANTS ARE ALL FIELD GROWN, ARE GIVEN CONSTANT CIOI AND CULTIVATION AND WHEN SE IT OUT ARE STRONG AND 'TTLL DEVELOPED, MUCH LARGER AND WORTH A GREAT DEAL MOFF MONEY THAN POT-GROWN PLANTS.

We do not divide our plants before shipping but sind the entire plant thote Dividing is only done in rare cases and only then because lt is necessary to get ibs best results.

\section{TERMS OF PAYMENT} Customers unknown to us will please, sond cash or refereoces with $t$ eir
is impossible for us to make immediate shipment to ew clients who do $t$ towi references or cheque with their order. NOT SENDING REFERENC is or ENCLOSING CHEQUE CAUSES DELAY IN THE FORWARDING OF THE STOCK YOU ORDER.

\section{GUARANTEES}

We guarantee all stock furnished by os to be fir t lass, true to nave, liviz and healthy, all of a size so as to give IMMEDIATE RESULTS.

However, there are so many causes for filure over which we have no zontrol thus we can assume no responsibility after stock is delive d. Poor soil, unfavor weather, ignorant or careless culture-all contribute to failure and are beyord nur control.

If, after receiving, you are not satisfied wilh he quality of the stock, let ue neof and we will replace anything you mention without charge or without que ti-n.

QUANTITIES ORDERED

We do not sell less than three plants of a klnd unless offered otherwn . I wew five plants are sold at hundred rate. Five hundred at thoosand rate

SHIPPING DIRECTIONS

Please give explicit shipping difectio-n, stong thether stock is to be sinipped th freight or express, and by what route.

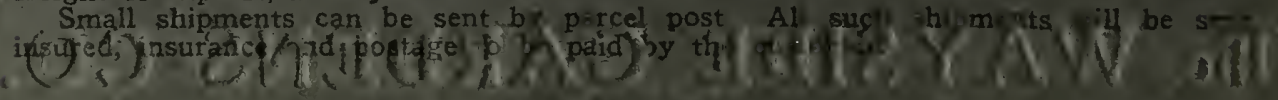

THE WPYSIDE GARDENSEONANANY

E. H. SCHULTZ

MENTOR, OHIO

J. J. GPULt. EMAKS

Presiden?

\section{Largest Growers of Hardy Plants in America}




\section{HigHEST HONORS}

WAYSIDE GARDENS exhibits win highest honors two years in succession. These awards represent the judgment of the keenest and most critical minds in our line of business. They reflect especially the plant material that went into the making of these gardens.

FU

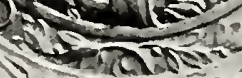

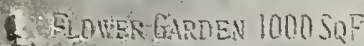

1925

AW ARDED BY CLEVELAND FLOWER SHOW AT THE SPRING FLOWER SHOW HELD IN CLEVELAND, 1925
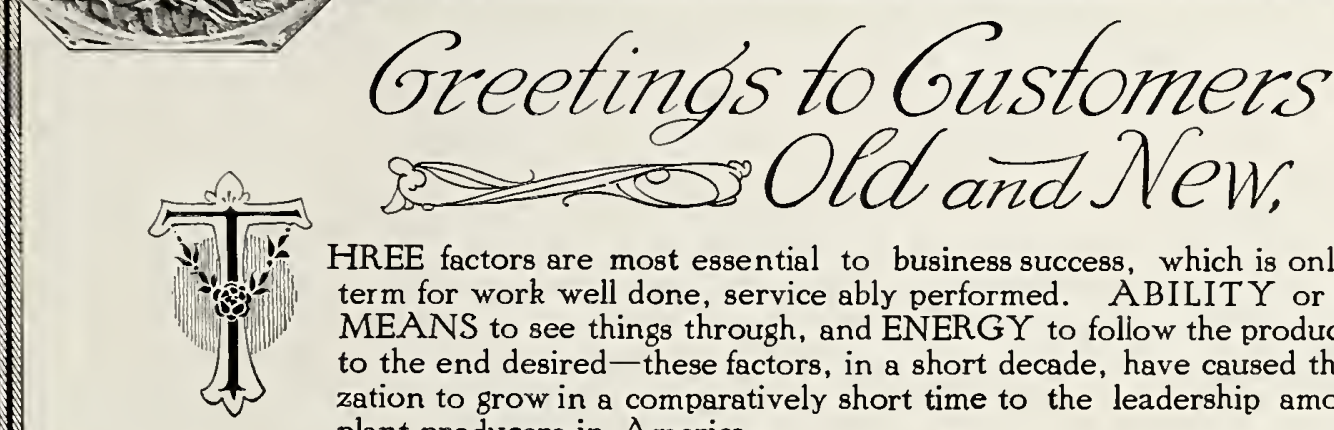

HREE factors are most essential to business success, which is only another term for work well done, service ably performed. ABILITY or skill, the MEANS to see things through, and ENERGY to follow the product thrcigh to the end desired - these factors, in a short decade, have caused this organization to grow in a comparatively short time to the leadership among hardy plant producers in America.

Back of it all, men and methods combine with but one ideal in mind-to produce and deliver the finest hardy perennial plants, rock plants, and lily bulbs obtainable anywhere. Our men have the skill! Combined with highly developed methods of culture on land ideally fit, we grow plants that within one short season produce finished gardens.

But our interest does not cease there. Above all, the buyer must be satisfied. It is our aim and ambition to cause Wayside Gardens to be looked upon as the last word in hardy plant service, the greatest source of a field-grown product, the like of which is unobtainable elsewhere.

We are deeply grateful to those who have helped us grow, for their confidence in our sincerity of purpose and their faith in our ability to make good any promise given in any of our advertisements or printed matter. With this goes the assurance that for 1926 we are splendidly prepared and equipped to take care of all orders that may be intrusted to us.

\section{GOLD MEDAL awarded by}

THE SOCIETY OF AMERICAN FLORISTS and ORNAMENTAL HORTICULTURALISTS

FOR

DUTCH BULBS AND

WALL GARDEN PLANTED WITH

ROCK PLANTS AT THE ANNUAL

SHOW HELD IN SPRING OF 1924 


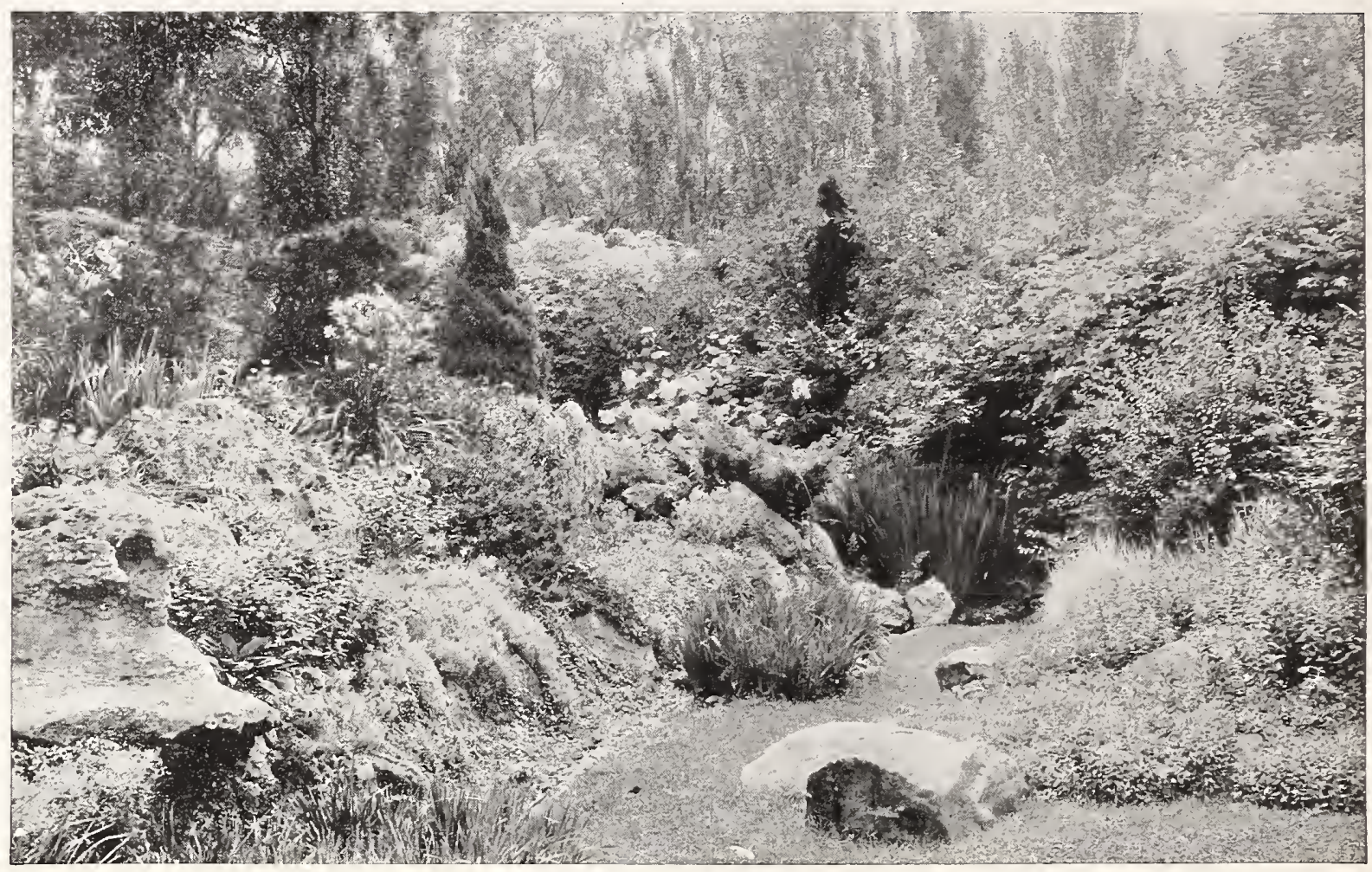

\section{Suggesting a Few Foolproof Rock and Wall Plants}

\section{Rock Plants}

Achillea tomentosa.

Aethionema. All varieties.

Alyssum. All varieties.

Auricula. Choice mixed hybrids.

Arenaria. All varieties.

Armeria. All varieties.

Asters, Mauve Cushion.

Aster alpinus. All varieties.

Callirhoe involucrata.

Calamintha alpina.

Catananche. All varieties.

Campanula carpatica.

Crucianella stylosa.

Coronilla varia.

Chrysanthemum Maximum, Glory of Wayside.

Dianthus. Various varieties.

Epigaea repens.

Euphorbia myrsinites.

Ferns. All varieties.

Geranium. All varieties.

Geum. All varieties.

Helianthemum. All varieties.

Hypericum. All varieties.

Iberis. All varieties.

Iris tectorum.

Iris pumila. All varieties.

Lavandula nana.

Leontopodium alpinum.

Linum. All varieties.

Lychnis alpina.

Lychnis Haageana.

Mazus rugosus.
Mitchella repens.

Mitella diphylla.

Oenothera. All varieties.

Papaver nudicaule. All varieties. Potentilla. All varieties.

Phlox subulata. All varieties.

Platycodon mariesi.

Plumbago larpentae.

Prunella granuflora.

Ranunculus. All varieties.

Scutellaria baicalensis.

Silene. All varieties.

Sedum. Dwarf varieties.

Stachys lanata.

Tunica saxifraga.

Verbascum. All varieties.

Veronica. All varieties.

Viola. All varieties.

Vinca minor.

Yucca filamentosa.

\section{Good for Shady Locations in the Rock Garden}

Ajuga. All varieties.

Anchusa myosotidiflora (or sun).

Anemone sylvestris.

Asperula odorata.

Campanula rotundifolia (or sun).

Convallaria majalis.

Cypripedium. All varieties.

Dicentra eximia (or sun).
Dodecatheon Meadia.

Gentiana. All varieties.

Hepatica coerulea.

Iris cristata.

Mertensia virginica.

Myosotis palustris sempervirens (or sun).

Pachysandra terminalis.

Phlox divaricata canadensis.

Polemonium reptans (or sun).

Primula. All varieties.

Saxifraga. All varieties.

Tiarella cordifolia.

Trillium grandiflora.

\section{Wall Plants}

Arabis. All varieties.

Aubrietia. All varieties.

Cerastium tomentosum.

Erysimum pulchellum.

Erinus alpinus.

Gypsophila repens.

Heuchera. All varieties.

Nepeta Mussini.

Pentstemon pubescens.

Saponaria. All varieties.

Saxifraga McNabiana.

Sempervivum. All varieties.

Sedum sarmentosum.

Sedum spurium coccineum.

Thymus. All varieties.

Valeriana coccinea.

Please note all wall plants may also be used as rock plants. 
ACHILLEA (Milfoil or Yarrow).

Plants suitable for dry, sunny places. The dwarf kinds ar $\Theta$ useful for carpeting ol' for rockeries; the taller varieties as border plants.

Doz. $100 \quad 1000$

apatorium (syn. filipendulina). 3 to 4
feet. Flat heads of brilliant yellow

flowers; finely cut toliage. Blooms all

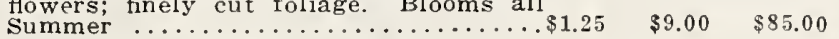

Millefollum roseum (Rosy Milfoil). July to October. Rosy pink flowers in dense heads, on stems 18 inches high. Effect-

ive on edge of shrubbery or in border . . $1.50 \quad 10.00$

Perry's White. 1 to 2 feet. June to September. A choice new variety; pure white flowers over one inch across;

broad, overlapping petals. Nothing

better for cutting .................... $1.25 \quad 9.00$

Ptarmica, The Pearl. Pure white, double flowers all Summer. Prized for cutting .. $1.25 \quad 9.00 \quad 85.00$

Ptarmica, Boule de Neige. New. An improvement on "The Pearl," with fuller borders ........................... $1.25 \quad 9.00$

Tomentosa. 6 to 8 inches. July to Sep-

tember. Bright yellow flowers. Excel-
lent for rockeries $\ldots \ldots \ldots \ldots \ldots \ldots \ldots$

ACONITUM (Monkshood).

Summer- and late Autumn-flowering plants with bold spikes of hood-shaped flowers, thriving in either sun or shade. The roots are poisonous and should not be planted where the tubers might be mistaken for vegetables. Delivery from October 15 th to March 15 th. Tubers cannot freeze.

Fischeri. A dwarf variety with pale blue Doz. $100 \quad 1000$ flowers. 18 inches. September $\ldots \ldots \ldots \$ 2.00 \quad \$ 15.00 \quad \$ 125.00$

Napellus (True Monkshood). 3 to 4 feet. July to August. Large dark blue flowers

in a raceme $\ldots \ldots \ldots \ldots \ldots \ldots \ldots \ldots \ldots$. $4.50 \quad 35.00$

Napellus alba. 2 to 4 feet. July to August. An effective plant. White-flowered form of Napellus ............... $4.50 \quad 35.00$

Napellus carneum. 2 to $21 / 2$ feet. JulyAugust. This variety has variegated red and white flowers; effective ..... $4.50 \quad 35.00$

\section{ACORUS (Sweet Flag).}

Calamus. 2 feet. June-July. Leares sword shape, erect; flowers inconspicuous. Root stock pungent, aromatic. Thrives best in moist soil, and may be grown in shallow water or dry land ... $1.50 \quad 10.00$

ACTEA (Baneberry).

Alba. $2 \frac{1}{2}$ feet. A very much improved form, having long spikes of clear white flowers. Good for cutting; effective border plant and shady woodland

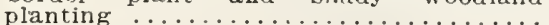

Rubra. Ped form of the above .......

ADONIS (Pheasant's Eye).

Amurensis (Spring Adonis). Early yel-

low flowers. Each, $75 \mathrm{c} \ldots \ldots \ldots \ldots . . . . .5 .00$

\section{AETHIONEMA (Persian Candytuft).}

Near relatives of the Candytuft, these hardy little rock plants are of the most fascinating character. The foliage of most of them is a beautiful glaucous blue: She foliage of most of covered with their heads of pink blossoms, make a picture not to be forgntten. We supply pot plants only, as field plants are hard to establish.

They are almost shrubby in habit and are improved by a slight cutting back after blooming. Stony sandy loam is suitable for them and a warm, sunny position. Given these conditions, they will grow more beautiful every year.

Grandifiora. Strong. twiggy bushes, cov-

ered with long, slender spikes of rosy

pink flowers. One of our best rock plants.
9 inches $\ldots \ldots \ldots \ldots \ldots \ldots \ldots \ldots \ldots \ldots \ldots$

Persicum. Somewhat deeper in color than

Grandiflora $\ldots \ldots \ldots \ldots \ldots \ldots \ldots \ldots \ldots \ldots \ldots+3.00 \quad 20.00 \quad 190.00$

AETHEOPAPPUS (See Centaurea).

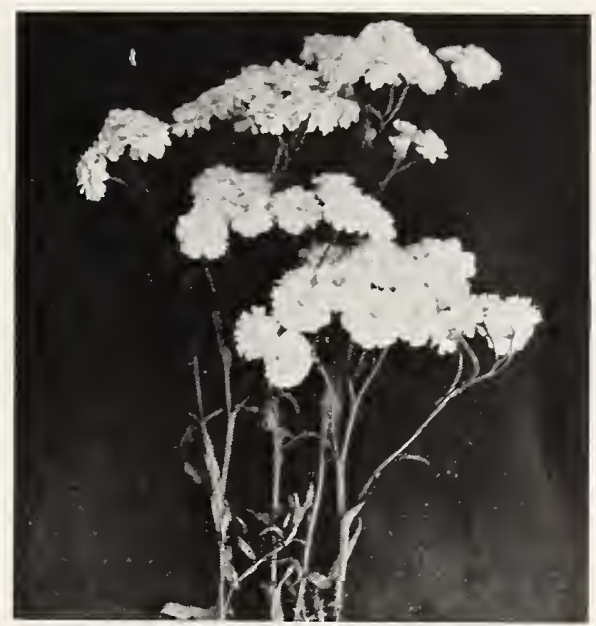

Achillea Ptarmica, "The Pearl."

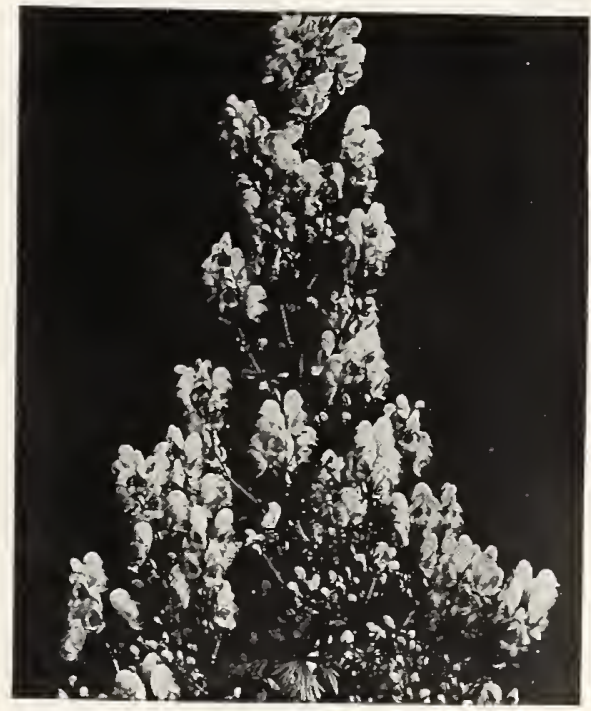

Aconitum Fischeri.

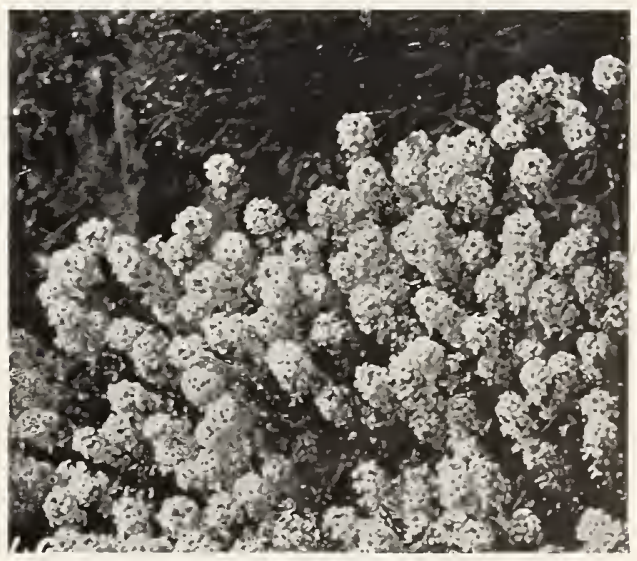

The Lovely Aethionema. 


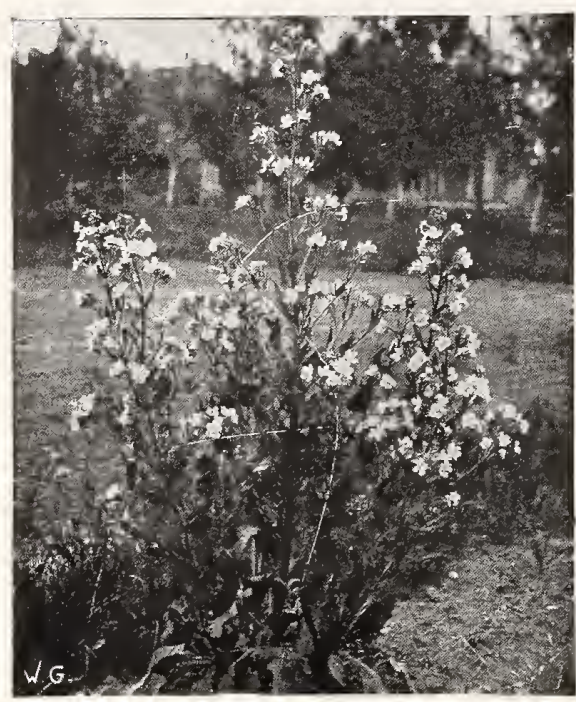

Anchusa Italica.

Is fine for border plant.

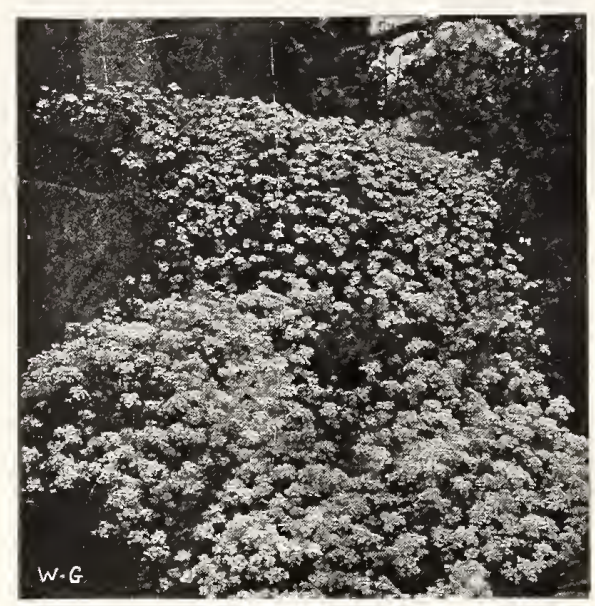

Alyssum Saxatile. Excellent for edging.

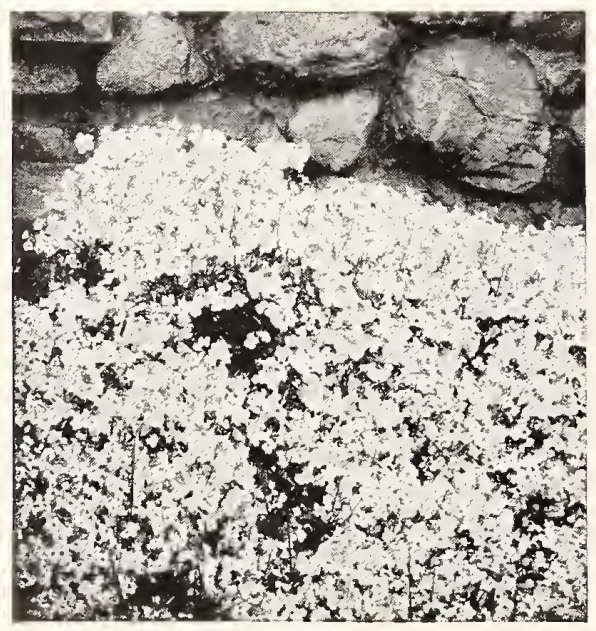

Arabis Alpina.
AGROSTEMMA (Rose Campion).

Stout, erect-growing plants with silvery foliage, which contrasts well with the showy flowers, which are produced during June and July.

Coronaria (Mullein Pink). Bright rosy Doz. $100 \quad 1000$

werimson. $2 \frac{1}{1 / 2}$ to 3 feet $\ldots \ldots \ldots \ldots \ldots \$ 1.25 \quad \$ 8.50 \quad \$ 70.00$

walkeri.
flowers

\section{AJUGA (Bugleweed).}

A useful plant for the rockery and for carpeting the ground particularly in shady positions, as under trees where grass will not grow; flowers in May and June.

Genevensis. Grows 6 to 8 inches high;

dense spikes of blue flowers ......... \$2.50 $\$ 18.00$

Reptans rubra. Grows 3 to 4 inches high,

with deep purplish blue flowers ...... $1.75 \quad 12.00$

1000

ALYSSUM (Rock Madwort).

Very popular for beds, borders and Winter flowering; of easiest culture and very free blooming. Seed may be sown very early in the Spring and up to June 15th, also in the Fall for early Spring blooming.

Argenteum. Dense growth. Leaves silvery beneath, fowers yell il sumer.

Rostratum (Alpestre). Prostrate, almost

Rostratum (Alpestre). Prostrate, almost
shrubby variety, hoary grey all over. shrubby variety, hoary grey all over.
Flowers pale yellow, in unbranched

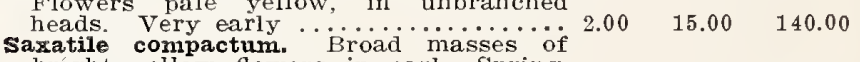
bright yellow flowers in early Spring An excellent plant for the rockery or front of borders. 1 foot $\ldots \ldots \ldots \ldots$. .

erph rith r.

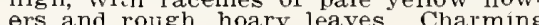
ers and rough, hoary leaves. Charming $200 \quad 15.00-140.00$

AMSONIA.

Tabernaemontana. 2 to 3 feet. Late May and early June. Small and numerous flowers of light blue in panicles. Smooth foliage resembling the olive. For the hardy border or planted among

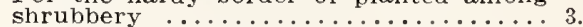

ANCHUSA (Alkanet).

For producing a mass effect of brilliant blue, the Anchusas cannot be surpassed. Dropmore, the darkest one, is most effective. Opal has larger flowers and is the best of the tall varieties, producing a solid sheet of soft turquoise-blue. They should be treated as biennials, as the old plants exhaust themselves at the end of two or thrce years. They reproduce themselves, however, from self-sown seed. The blooming season can be extended for several weeks by cutting the spikes as soon as the flowers fade, thus preventing seeding.

Dropmore. Tall spikes of beautiful blue flowers, flowering all summer. Rough,

broad foliage. 4 to 5 feet ..........\$1.75 $\$ 12.50 \quad \$ 110.00$

Opa1. Very beautiful variety, with large,

pale blue flowers. 3 to 4 feet $\ldots . . .1 .75 \quad 12.50 \quad 110.00$

myosotidifiora. A distinct, dwarf peren-

nial variety from Russia, with clusters

of charming blue flowers resembling forget-me-nots. An effective rock plant

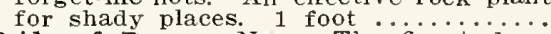

Pride of Dover. New. The finest deep rich blue of all. 3 to 5 feet (Sold out for this season).

ANTHEMIS (Marguerite).

Tinctoria. Handsome, finely cut foliage, and large, golden yellow flowers produced all summer. Succeeds in the

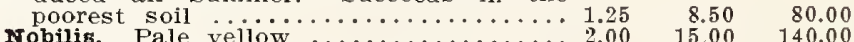

ARABIS (Rock Cress).

Alpina. Pure white flowers produced in dense masses, splendid for border and rockery work, and last quite some time

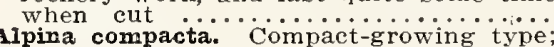

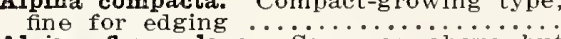

Alpina flore pleno. Same as above but

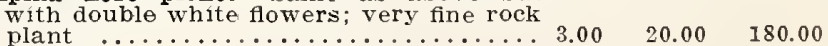

AURICULA (Swiss Primrose).

Mixed Auriculas should be in every rock garden; flowers are heavily covered with a mealy substance which makes them look like butterfly wings. 


\section{ANEMONE - Windflower}

ANEMONE JAPONICA (Japanese Anemone).

Valuable plants suitable for massing or single specimens. They grow rapidly and are profuse in bloom, gaining strength and beauty each year. The blooming period extends from August till mid-November. the large, oren flowers furnishing abundant cut flowers and a brilliant field display. Cover plants in Winter. We offer strong, field-grown roots only.

$\underset{2}{\text { Alba. }} \begin{gathered}\text { Purest white, with yellow centel. } \\ 3 \text { feet } \ldots \ldots \ldots \ldots \ldots \ldots \ldots \ldots \ldots \ldots \ldots \ldots\end{gathered}$

Alice. Large flowers of rose, carmine,

lilac center ......................2.00 $15.00 \quad 125.00$

Buhler Kind. Early double white .... $3.00 \quad 20.00 \quad 175.00$

Kriemhilde. Double, rich pink; of excel-

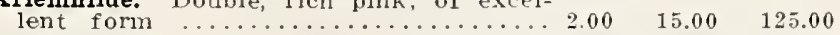

Max Voget. Double pink $\ldots \ldots \ldots \ldots \ldots 3.00 \quad 20.00 \quad 175.00$

Prince Henry. Double red flowers:

Queen Charlotte. Abundant semi-double

"Lowers, broad and perfectly formed; $2.00 \quad 15.00 \quad 125.00$

Richard Ahrends. Large white flowers

with lilac hue ...................... 2.00 $15.00 \quad 125.00$

Rubra. Beautiful rosy red; stamens

bright yellow ....................... $3.50 \quad 25.00$

whirlwind. Excellent double white flow-

ers. 2 to 3 feet ................. $1.50 \quad 10.00$

\section{ANEMONE SPECTES}

Hupehensis (Early Anemone). Was originally introduced from central China. is closely allied to Anemone japonica, which, in a miniature form, it resembles. The plant orows from 10 to 12 inches high plant frows from in August until high and from early in August until of flowers about $11 / 2$ inches in diameter,

of a pleasing maure-rose ..........

the above $\ldots \ldots \ldots \ldots \ldots \ldots \ldots \ldots \ldots \ldots$

Pulsatilla (Pasque Flower). Grows from 9 to 12 inches high and produces viole or purple flowers during April and May. An interesting plant for the rockery or

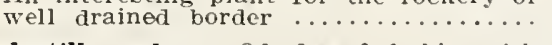

Pulsatilla rubra. Of $d x$ arf habit with

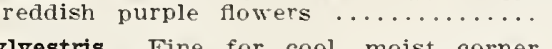

sylvestris. Fine for cool, moist corne of rock garden or border. Large. white inches. Very free blooming. May and
ing

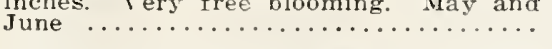

Vernalis (Iady of the Snow). A rare and exquisite alpine. Large, open Easily grown in rich vegetable soil in full sun. Tery choice ...................... 3.00

ANTHERICUM (Paradisea).

Iiliastrum major (St. Bruno's Lily).

Flowers white. with narrow, grass-like

foliage. $1 \frac{1 / 2}{2}$ feet. May-June ..... 4.00

ARENARIA (Sandwort).

Montana. A hardy perennial growing in close tufts, profusely covered with small, silvery white flowers which appear quite early in the season. Excellent as an edging plant in formal gardens. Suitable for rockeries in sunny places. Flowers resemble small, white, upturned morring glories ...........................

Grandiflora. From the Pyrenees Mountains. Covers itself with its pure, snow-white flowers. One of the best of all rock plants. May $\ldots \ldots \ldots \ldots \ldots \ldots .1 .75 \quad 12.50 \quad 100.00$

\section{ASCLEPIAS (Butterfly Weed)}

Tuberosa. Attractive native plants. flowering during July and August, and growing about $21 / 2$ feet high. Umbels of bright orange colored fowers ..... 1.50

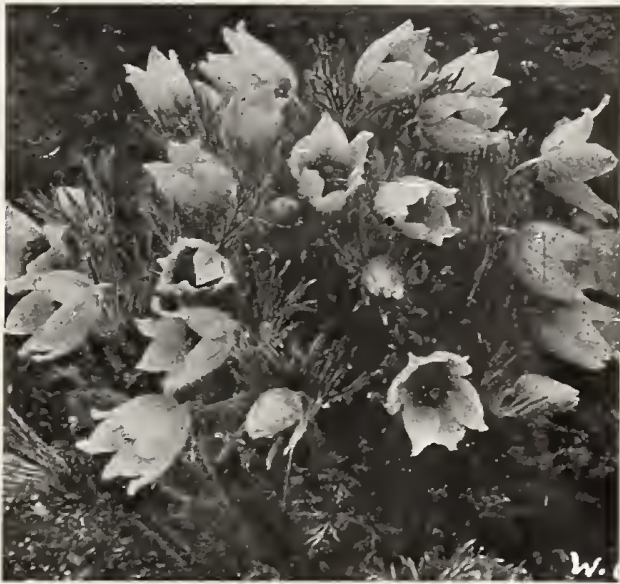

Anemone Pulsatilla.

One of the earliest flowering rock plants.

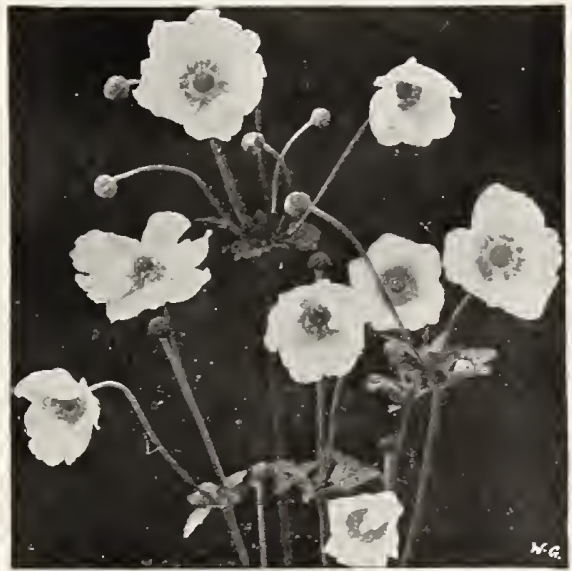

Anemone Japonica Alba.

The hardiest of all Japanese Anemones.

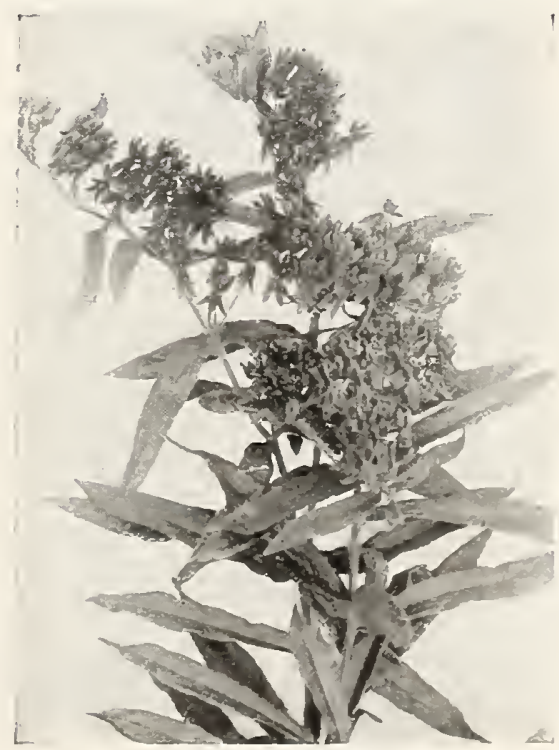

Asclepias Tuberosa 


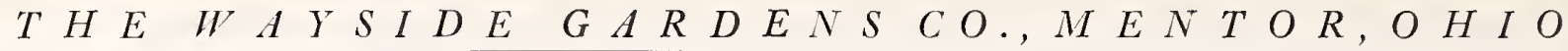

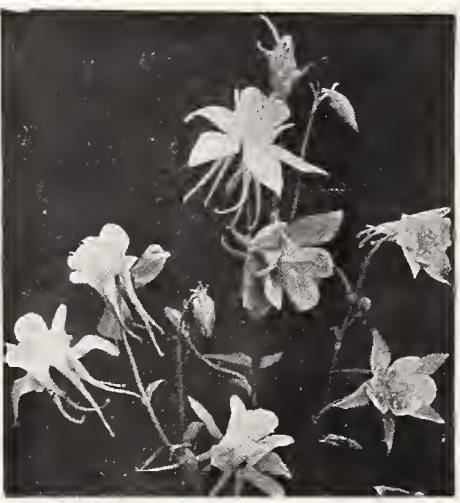

Aquilegia-Columbine.

Scott Elliott Hybrids are the best.

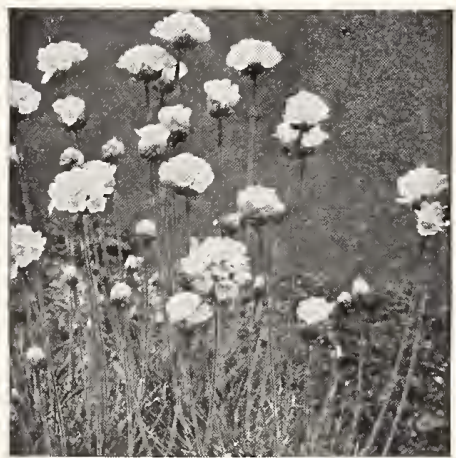

Armeria-Sea Pink; Thrift.

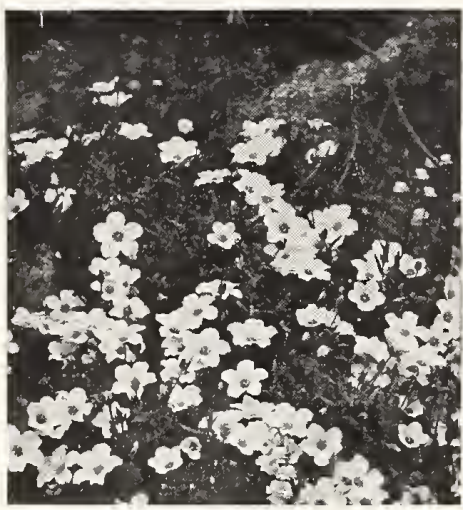

Arenaria Montana.

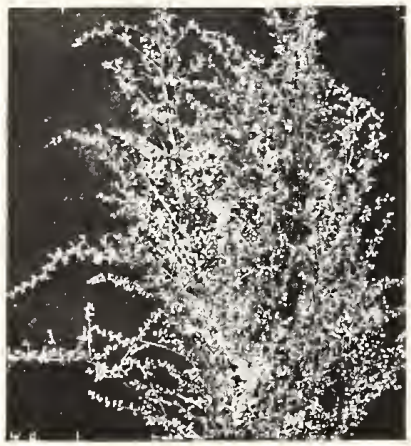

Artemisia Lactiflora.

\section{AQUILEGIA - Columbine}

As a cut flower the Long-Spurred Aquilegias are the daintiest of our outdoor grown flowers. They come in blues, whites and yellows, and shades of pink and rose in strains reasonably true. Practically all the various shades and colors are in the Coerulea Hybrids. They remain in bloom for a long season and are vigorous and long lived. They are not at all particular as to soil or location, although they prefer a sandy loam and a moist but well drained sung position, and usually make themselves at home in at home in any haken ering covers the late spring and early summer months raken as a whole, they are a most important part of the hardy garfashioned garden flowers.

Canadensis (Common American Colum-

Doz. $\quad 100 \quad 1000$

bine). The native bright red and yel-

low variety, and one of the brightest. $\$ 1.25 \quad \$ 9.00 \quad \$ 80.00$

chrysantha. Beautiful golden yellow

flowers; blooms for two months ...... $1.25 \quad 9.00 \quad 80.00$

Chrysantha alba. A white variety of the

above ............................ $1.25 \quad 9.00 \quad 80.00$

Coerulea. Blue shades ............2.00 $2.00 \quad 15.00 \quad 140.00$

Crimson Queen. Beautiful crimson flow-

$1.50-10.00$

Iong-Spurred Hybrids, Mixture $\ldots \ldots \ldots .1 .25 \quad 8.00 \quad 70.00$

Mrs. Scott Flliott Fybrids. There is not a better mixture grown in the world than by Mrs. Scott Elliott, who has taken the highest awards at all the European exhibitions. Wonderful colors with very long-spur from stock is from seed from this source,
absolutely true strain ............. $1.75 \quad 12.00 \quad 100.00$

snow Queen. The best white. longspurred variety known ............. $1.50 \quad 10.00 \quad 90.00$

Wayside Pink. A beautiful strain of nothing but clear pink colors. We do not think that they can be surpassed .... $1.75 \quad 12.00$

100.00

ARMERIA (Sea Pink or Thrift).

Attractive dwarf plants that will succeed in any soil forming evergreen tufts of bright oreen foliage, from which innumerable evergreen tufts of bright green foliage, from which innumerable flowers appear in dense heads, on stiff, wiry stems, from 9 to
12 inches high. They flower more or less continuously from early Spring until late in the Fall. Very useful in the rockery and border edgings. with A dwarf plant with evergreen leaves and heads of light
pink flowers. 10 inches. May-June ...\$2.00 $\$ 15.00 \quad \$ 125.00$

Formosa. 6 to 8 inches ............. $1.75 \quad 12.00 \quad 100.00$

Laucheana rosea. Bright rose. 3 to 6

Maritima (Thrift or Cushion Pink). to 6 inches. May and June. Valuable for edging; flowers pale pink; foliage grassljke, evergieen .................. $1.75 \quad 12.00 \quad 100.00$

Maritima alba. 3 to 6 inches. May and June. Tufts of deep green foliage;

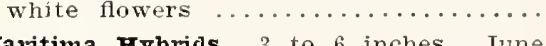

Maritima Hybrids. 3 to 6 inches. June to October. Large flowers of delightful
white, rose and pink shades. Very usewhite, rose and pink shades. Very use-
ful for edging and eutting ............ $1.75 \quad 12.00$

ARTEMISIA (Sage Brush).

Iactiflora. A tall-growing plant of fine foliage and heads of small white flowers in August and September, which did and graceful eut flower.

\section{ASPERULA (Woodruff)}

Odorata. 6 to 8 inches higlı. May. Habit erect; leaves usually in a whorl of eight. finely toothed. Jncreases rapidly and is used for carpeting shady places and for edgings. Heads of snowy white flowers. A fine, scented herb ........ $2.50 \quad 18.00 \quad 170.00$

\section{ASPHODELUS (King's Spear).}

Iuteus. Tall spikes of bright yellow, liky-like flowers; very fragrant; swordlike foliage; fine for borders $\ldots \ldots \ldots \ldots 1.75 \quad 12.00 \quad 100.00$ 


\section{New Imported Hardy Asters}

We aro offering on this page a collection of New Hardy Asters. The newest varieties are indicated thus (*), and were selecter by Mr. Grullemans, while in Europe, from more than a hundred recent introductions. We have priced them reasonably, and sucgest their use in place of the older and less attractive varieties which are commonly listed.

\section{HARDY ASTERS (Michaelmas Daisies)}

The many species, widely distinct from each other in habit and form, are with a few exceptions, all native of North America. It is in Furope, however, that our Asters have been most highly appreciated. Many improvements have been made by European growers, and many hybrid forms have been produced by urossing the different species. For the best results, they require division and replanting every third year.

$\begin{array}{llll}\text { Doz. } & 100 & 1000\end{array}$ petunia-riolet. (Sold out for this season).

*B1ue Gem. Double flowers of rich blue.. $\$ 2.50 \quad \$ 18.00 \quad \$ 170.00$

*Charm. Very double violet-blue flowers.. $2.50 \quad 18.00 \quad 170.00$

*Erica. A beautiful clear pinli; large

double flower's .................. 2.50 18.00

*Elta (New). Double flowers of pale lilac.

Very handsome shade ............. $2.50 \quad 18.00$

Feltham Blue. A pretty aniline-blue; very $1.50 \quad 10.00$

Glory of Colwall. Good sized, almost

double; ageratum-blue flowers ........ $1.50 \quad 10.00$

*Grey Lady. Exquisite shade of opal, with

large, semi-double flowers. Extra fine. 2.50 18.00

* Heather Glow. Extr“ì large flowers, freely produced, of a delightful rose-pink shade. $4^{1 / 2}$ feet. (Sold out for this season).

*Joan Vaughan. Large, semi-double flow-

ers of deepest blue ..................

pink. Lasts exceedingly well. 3 feet . . 2.50 18.00

*Mauve Queen. Very large, semi-double flowers of clear maure. 4 feet $\ldots \ldots .2 .50 \quad 18.00 \quad 170.00$

* Maid of Colwall. Pure white; the finest of all whites. Long, loose spikes of huge flowers....................... $2.50 \quad 18.00$

Maggie Perry. Tery large flowers, frequently $21 / 2$ inches across, loosely arranged in large trusses, of a pleasing
tone of soft maure. Most distinet and

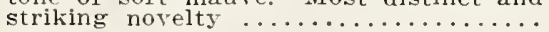

Mrs. Raynor. The deepest red of all Asters $\ldots \ldots \ldots \ldots \ldots \ldots \ldots \ldots \ldots \ldots \ldots \ldots \ldots$.

* Nancy Ballard. Deep purplish mauve flowers, semi-uouble in form; flower with masses of bloom ...............

Novae-angliae roseum superbum. This is a new introduction of our own, and is by far the best Aster we have ever seen. Color almost red and a profuse bloomer. 1.50

Novi-belgi climax. One of the best and showiest, with large, pyiamidal spikes
of large, light lavender-blue flowers; very free; 5 feet $\ldots \ldots \ldots \ldots \ldots \ldots \ldots \ldots$

Novi-belgi St. Egwin. A pleasing rosy pink; very free blooming. 3 to 4 feet.. $1.50 \quad 10.00$

*Perry's White. The finest white Michaelmas Daisy yet introrluced: perfect in habit and remarkably free flowering. covered with flowers $21 / 2$ inches across..

*Peggy Ballard. Large, pyramidal sprays of double, rosy mauve towers. 3 feet.. 2.50 18.00

*Queen of Colwall (New). One of the finest of late introductions: large. stout branching stems, covered with pale
mauve blooms. Tall ............... 2.50 18.00

*Robinson $\mathbf{v}$. C. A pretty bluish mauve,

double flowers borne in long sprays...2 2.50 18.00

Robert Parker. Pale heliotrope. 4 feet.. $1.75 \quad 12.00$

90.00

90.09

170.00

170.00

140.00

$12.00 \quad 100.00$

18.00

170.00

10.00

90.00

90.00

$90.0 \cdot 3$

100.00

170.00

170.00

170.00

100.00

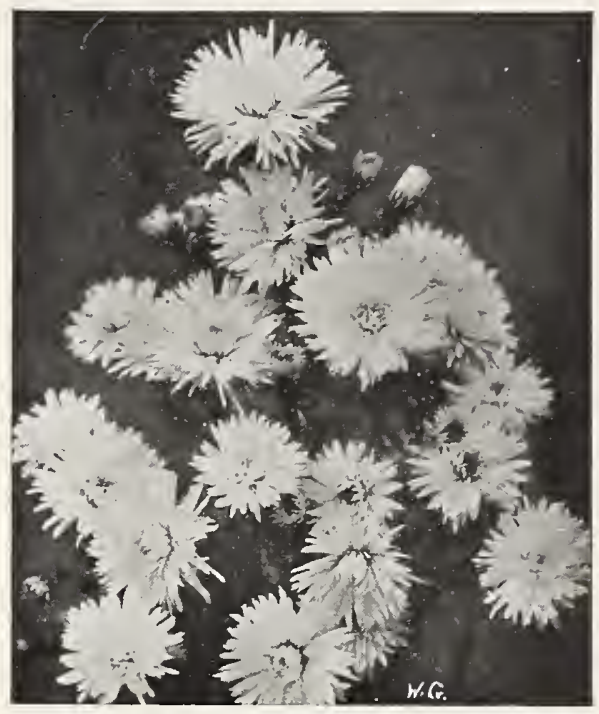

Aster, Elta.

New and a fine deuble lilac variets.

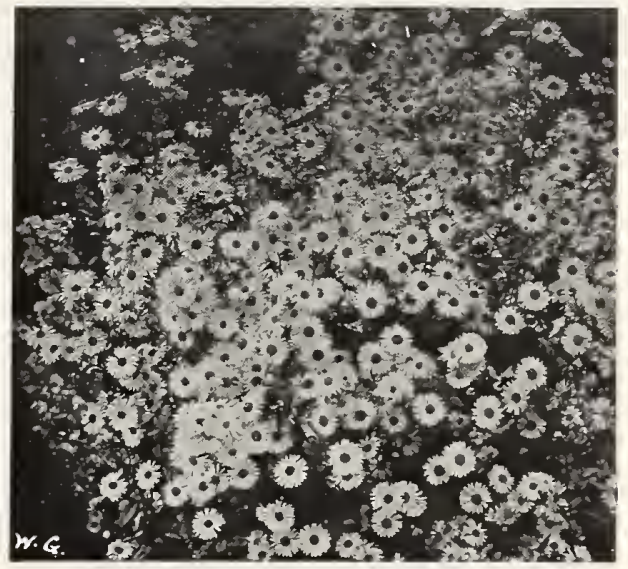

Aster, Novi-Belgi Climax.

The best for cutting.

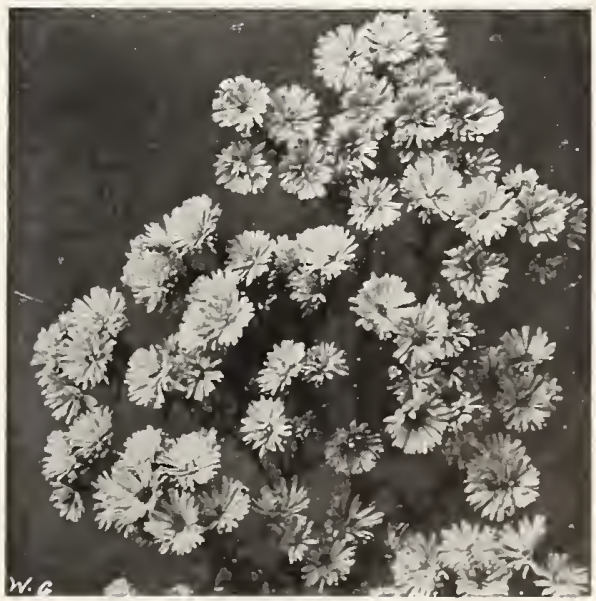

Aster, Perry's White. 


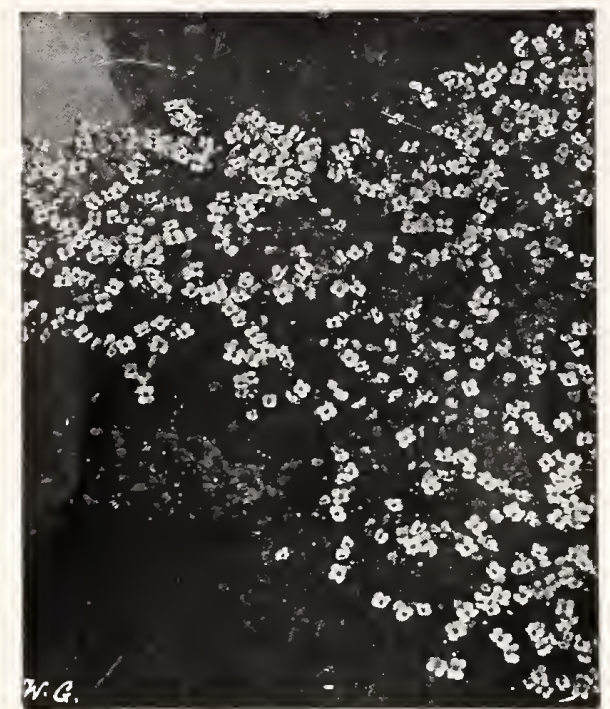

Aubrietia.

A fine wall plant for a sunny spot.

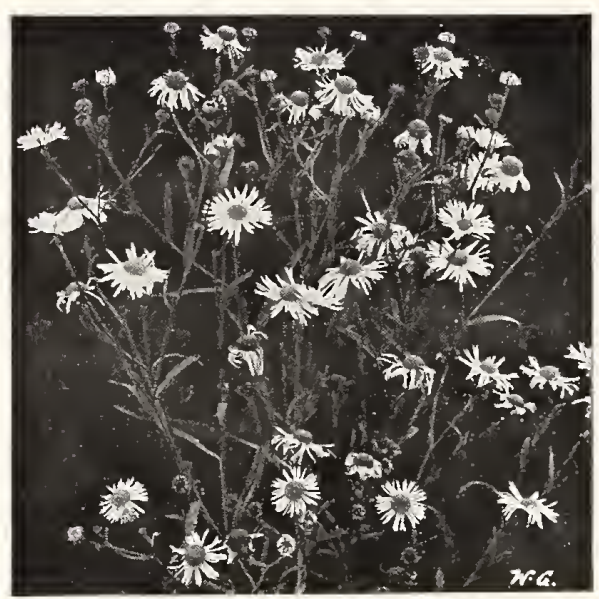

Boltonia Latisquama.

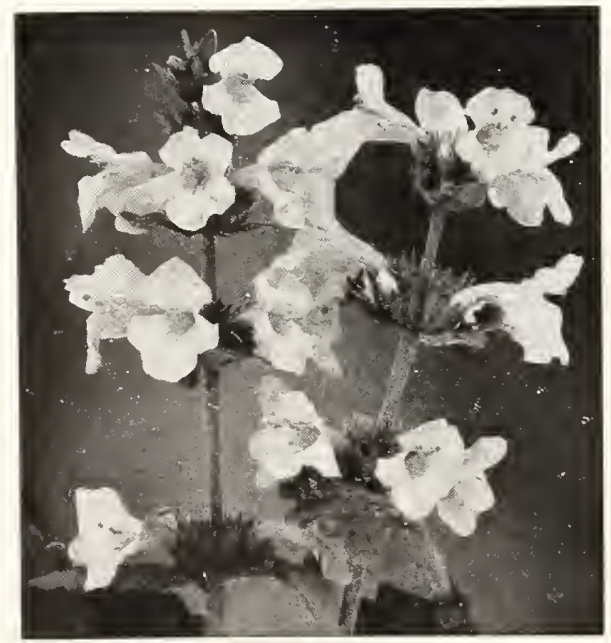

Betonica Grandiflora.
NEW JAPANESE HARDY ASTER

Mauve Cushion. Distinct species which

has attracted much attention by its

unique habit of growth, its floriferous-

forms a circular cushion-like plant 21

forms a circular cushion-like plant across, the center of the plant

feet across, the center of the plant
rarely exceeding 9 inches in height

gradually tapering to 3 to 4 inches at

the outside; the flowers, of delicate

mauve, with silvery white reflection.

measure over $1 \frac{1}{4}$ inches in diameter

and are produced in such lavish pro-

fusion as to completely cover the plant;

the blooms are at

vember .................. $\$ 2.50 \$ 18.00 \$ 170.00$

\section{ASTER ALPINUS (Dwarf Alpine Aster)}

$\begin{array}{lllll}\text { Alpinus albus. Large, white flowers } \ldots & 2.50 & 18.00 & 170.00\end{array}$

Goliath. Indispensable for the rockery

or edge of hardy borders; 6 to 10

inches high, and bears large, showy,
bluish purple flowel's in May and June. 2.50

Sub-coeruleus. Forms a dense tuft of

leaves, from which issue many leafless

stems 12 inches high bearing in June

and July massive bluish violet flowers

3 inches in diameter .......... 1.50 10.00

90.00

Tataricus. Distinct, large bluish trolet; $1.50 \quad 10.00 \quad 90.00$

very late. 6 feet $\ldots \ldots \ldots \ldots \ldots \ldots \ldots .1 .50 \quad 10.00$

ASTER AMEIIUS

Elegans. Long, graceful splays of soft $1.50 \quad 10.00 \quad 90.00$

ASTILBE (See Spirea).

AUBRIETIA (Rock Cress or False Wall Cress)

One of the daintiest and most delicately beautiful of all dwarf creepino plants for arpeting beds or rockeries forming brilcreeping plants for carpeting beds or rockeries, forming brilon rockeries or in borders with white Arabis and yellow Alyssum, it forms a charming contrast. A gem for planting in crevices of rocks or wall, forming a cataract of color.

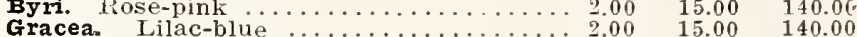

Hendersoni. Violet ................ $2.00 \quad 15.00 \quad 140.00$

$\begin{array}{llll}\text { Purpurea. Rich purplish blue } & 9.00 & 15.00 & 140.00\end{array}$

(Raised from seed, color varies).

BAPTISIA (False Indigo)

Australis. Dark blue, pea-shaped flowers

in June; suitable for the liardy border

or wild garden. Very attractive fo-
liage. 2 feet ...................... $1.50 \quad 10.00 \quad 90.00$

BELAMCANDA (See Pardanthus Chinensis).

BELLIS (Double English Daisy).

Perenne. NIammoth white snowball ... $1.25 \quad 8.00 \quad 70.00$

Perenne. Mammoth pink. Longfellow... $1.25 \quad 8.00 \quad 70.00$

BERGAMOT (See Monarda).

BETONICA (Betony).

Grandifiora. Close tufty foliage with

bright rose flowers ................ $1.50 \quad 10.00$

90.00

BLEEDING HEART (See Dicentra).

BOCCONIA (Plume Poppy).

Cordata. A noble hardy perennial, beautiful in foliage and flower, and adapted for planting in the shrubbery borders, center of beds, and in bold groups in any position. It will grow in any soil or situation, attaining 6 to 8 feet in height. Flowers creamy white in terminal panicles during July and August ........ $1.50 \quad 10.00$

90.00

BOLTONIA (False Chamomile).

A showy native hardy perennial plant with large single, dsterlike shor sumer and dutumn months, and with its thousands of flomels open at one time produces a very showy effect.

Asteroides. White form of Latisquama. $\begin{array}{rrr}\text { Doz. } & 100 & 1000 \\ \$ 1.25 & \$ 9.00 & \$ 80.00\end{array}$ Iatisquama. Pink, slightly tinged with lavender. 4 to 6 feet $\ldots \ldots \ldots \ldots \ldots \ldots .1 .25 \quad 9.00 \quad 80.00$

BUDDLEIA (Butterfly Bush).

Variabilis magnifica. This is really a shrub, but the top usually freezes back, and new growth starts from the root like other perennials. Plants grow 3 to 4 feet and are covered with long to 4 feet and are covered with long racemes of lilac-like flowers all sum- 
BUPHTHALMUM (Ox-eye Daisy).

Doz. $\quad 100$

1000

Salicifolium. Bears large, rich, golden

yellow flowers through the summer.

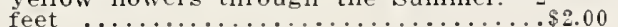

$\$ 15.00$

CALAMINTHA (Calamint).

Alpina. A yery graceful littls rock plant; growing 6 inches high, with rich purple flowers ..................... $1.50 \quad 10.00$

CALLA

Elliottiana. A grand rich golden yellow variety of the Arum Lily. (For spring delivery only) ................... 3.00

20.00

CALLIRHOE (Poppy Mallow).

Involucrata. An elegant trailing plant, with finely divided foliage and large, saucer-shaped flowers of bright rosy crimson, with white centers, which are

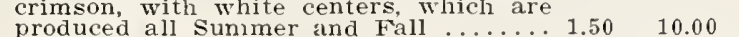

\section{CALTHA.}

Palustris (Marsh Marigold). 6 to 15 inches high. Flowers bright yellow in Spring. A very showy plant in wet places, both in sun and shade. It can be planted in brooks, and may be

grown in pots .....................

CARNATIONS (Hardy Border).

Double Scarlet $\ldots \ldots \ldots \ldots \ldots \ldots \ldots \ldots \ldots \ldots$

Double White Choice Mixed. Seeding................

Choice Mized. Seedings from seed sup-
plied by a specialist. Strong plants that will furnish an abundance of flowers. We strongly recommend this grand strain for cut flowers. They keep up a most wonderful supply from June till frost ........................ $1.50 \quad 10.00$

$2.00 \quad 15.00$

$1.50 \quad 10.00$

$\begin{array}{rr}1.50 & 10.00 \\ 1.50 & 10.00\end{array}$

125.00

ARYOPTERIS (Blue Spirea).

Mastacanthus incana. A handsome hardy perennial; grows about 3 feet high and produces rich lavender-blue flowers in great profusion the whole length of the branches. A valuable plant either for bedding or pot culture, blooming continuously from early in september until cut by

CASSIA (Indian Senna).

Marylandica. Handsome pinnate foliage and numerous racemes of showy yel-

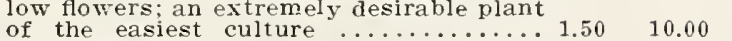

CATANANCHE (Cupid's Dart).

Bicolor. Similar to above, with white

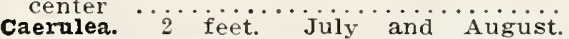
Heads of pretty deep blue flowers on long stems. Profuse and excellent cut

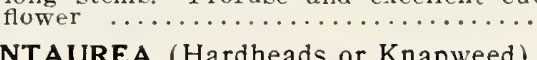

CENTAUREA (Hardheads or Knapweed).

Makes a fine display in the border; also excellent for cutting.

Aetheopappus pulcherrimus. Large, bright

Dealbata. Large and striking rose-pink flowers. June-July. 2 feet $\ldots \ldots \ldots \ldots .61 .50 \quad 10.00$

Macrocephala. Large thistle-like golden yellow flowers: useful for cutting and showy in borders. July and August.

$31 / 2$ feet 3 (Perennial Cornfower). "Grows

m feet high, bearing large violet-blus 2 feet high,

Montana alba .....................................

Ruthenica. Very tall plant with hand-

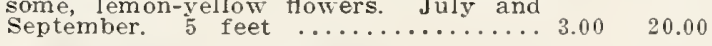

CENTRANTHUS (See Valeriana).

CEPHALARIA (Roundhead).

Tatarica. 6 feet. July and August. Fla heads of showy cream-white flowers. Suited for lear of borders, where effects

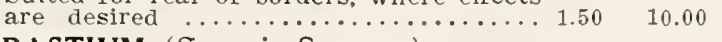

CERASTIUM (Snow-in-Summer).

Boissieri. I0 to 12 inches. June. Lowgrowing; leaves silvery; large, pure white flowers. Good for covering dry

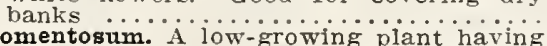

\section{1}

silvery white foliage and producing an abundance of snow-white flowers. Es-

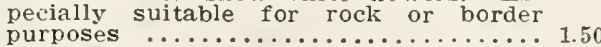

CERATOSTIGMA (See Plumbago Larpentae).

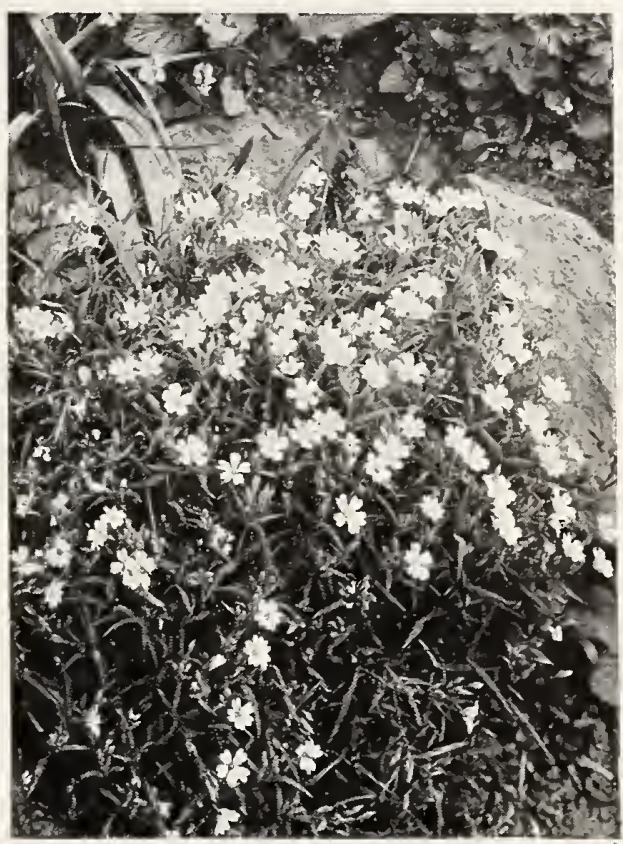

Cerastium Tomentosum.

Showy rock or wall plant, easy to grow.

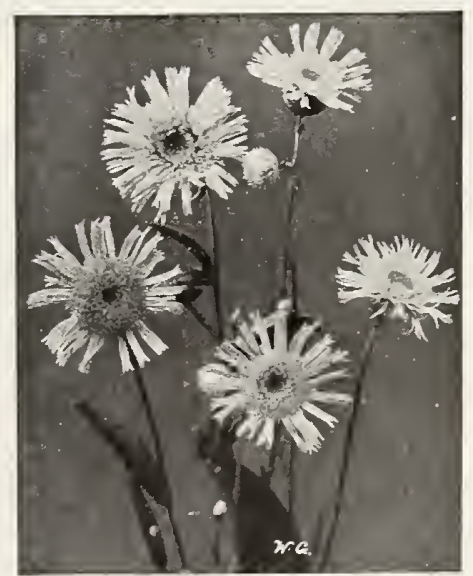

Catananche.

Likes a hot, dry place in the garden.

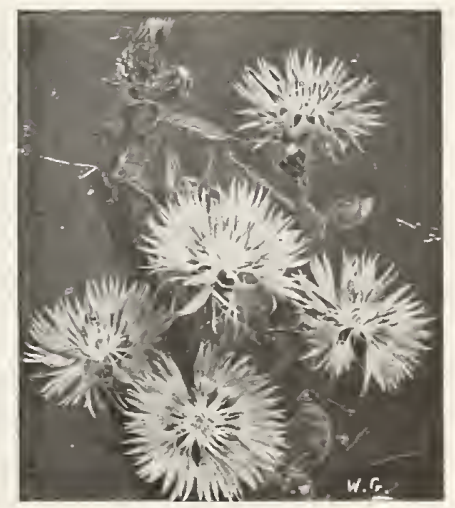

Centaurea Dealbata. 


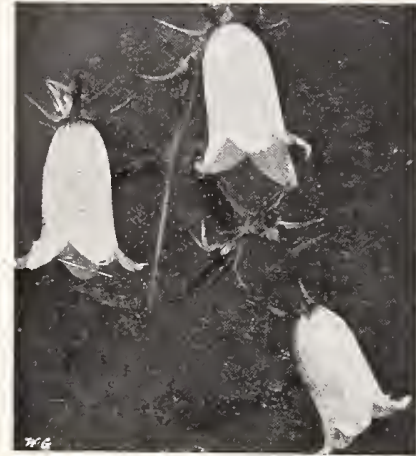

Campanula Rotundifolia.

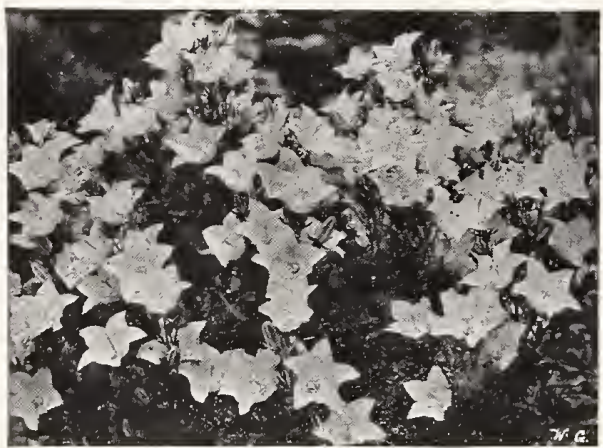

Campanula Carpatica.

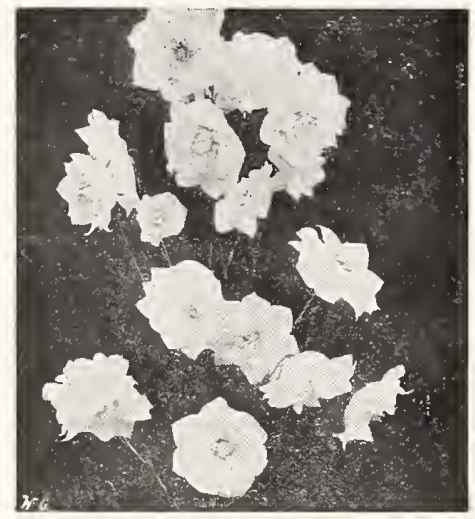

Campanula, Double Persicifolia.

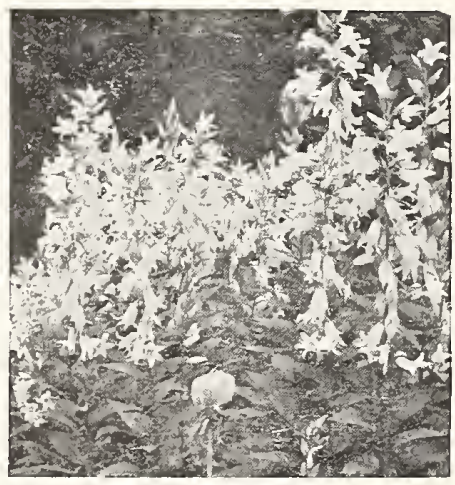

Campanula Latifolia.

\section{CAMPANULA - Bellflower}

Indispensable hardy garden flowers, of much variety of form, some being of tall and imposing habit, while others are dwarf. compact little piants, suitable for edging, rockwork, etc. They like a ood, rich soil, and last much longer in bloom if planted in a half-shady place.

Alliariaefolia. A orand border plant with Doz. 100

1000

tall spikes of long, pendent bells.

feet .................. p3.00 \$20.00

Bononiensis. Small, blue flowers borne protusely on slender stems. June. $21 / 2$

$\begin{array}{lll}\text { feet } & 3.00 & 20.00\end{array}$

Carpatica (Carpathian Harebell). A pretty species growing in compact tufts, not exceeding 8 inches high; flowers clear blue, held erect on wiry stems. It begins blooming in June, continuing until October. As an edging for a hardy border or for the rockery it is unsurpassed. $1.50 \quad 10.00$

90.00

Carpatica alba. A pure white form of the preceding ........................... 10.00

Divaricata (North Carolina Harebell). Strong plants .......................... 12.00

Elegans. Fine Campanula for borders and

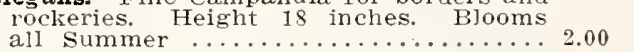

Garganica. A gem for the rock garden. Forms a low, spreading tuft which in June is covered with starry, light blue flowers having a white eye. Exquisite

hanging over a rock ...........

Glomerata. A farolite old-fashioned herbaceous plant producing deep blue flowers in large, close heads. Height 18

actiflora alba magnifica. A beautifuI va-

Iactiflora alba magnifica. A beautifuI variety from the Imperial gardens of
Petrograd, producing spikes 6 feet high, Petrograd, producing spikes 6 feet high,
bearing large, snowy-white flowers. New and choice. The true variety .... 4

Iactifiora coerulea. Pale blue flowers during July and August. $21 / 2$ feet $\ldots 2.00 \quad 15.00 \quad 135.00$

Iatifolia macrantha. 3 feet. June and July. Very handsome, enormous drooping bells of fine satiny lilac and deep ing bells of fine satiny lic and deep 1.7

Persicifolia grandiflora alba (White). One of the finest Campanulas, with large, great acquisition. Height 2 feet ......

Persicifolia grandifora alba flore pleno. Double-flowered form of the above ... $3.00 \quad 20.00$

Persicifolia grandiflora coerulea (Blue). An excellent companion to the white variety, the large bright blue flowers making an effective contrast. Height 2

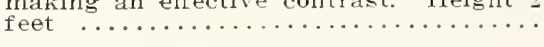

Persicifolia grandiflora coerulea flore pleno. Double-flowered form of the above . $3.00 \quad 20.00$

Fyramidalis. Mixed colors. An elegant pot plant. Height 4 feet ........... $1.50 \quad 10.00$

Raddeana. Tiolet-blue, bell-shaped flowers. A grand dwarf sort. 9 inches ... $3.00 \quad 20.00$

Rotundifolia (Blue Bells of Scotland or Harebells). 1 foot. June to August. In the wild it is more slender and taller than in the garden; clear blue flowers. Especially suited for crevices in the rock garden, or steep slopes, if planted

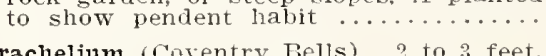

Trachelium (Coventry Bells). 2 to 3 feet. July and August. Sturay, hairy plant,

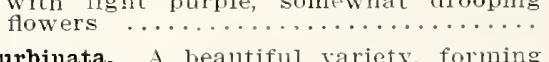

Turbinata. A beautiful raricty, forming close mats of foliage and bearing large plant and rairly smothering it. June and July .......................... 4.00

Turbinata alba. Similar to the above with large, white flowers .......... 4.00 30.00 90.00

140.00 
CAMPANULA MEDIUM (Canterbury Bells).

These imposing herbaceous hardy biennials ar $\theta$ profusely covered with large, bell-shaped flowers; extremely showy in shrubberies and mixed borders. Height 3 feet. Plants potted in October make most beautiful plants for the conservatory and greenhouse in the Spring, coming into flower, without being forced in any way, about two months before those in open ground.

Calycanthema (Cup and Saucer). Large, Doz. $100 \quad 1000$ semi-double flowers, each resembling a cup and saucer

Pink. Beautiful variety; charming pink flowers $\ldots \ldots \ldots \ldots \ldots \ldots \ldots \ldots \ldots \ldots$. $\ldots \ldots$.

white. Similar to preceding, but flow-

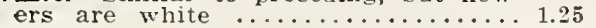

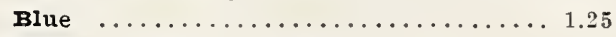

Medium (Single Canterbury Bells).

Pinz. Beautiful rich shades ........ 1.25

Blue. Light flowers $\ldots \ldots \ldots \ldots \ldots \ldots \ldots . \ldots \ldots$

White. Large, white flowers ........... 1.25

Medium flore plemo (Double Canterbury Bells).

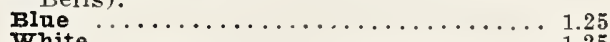

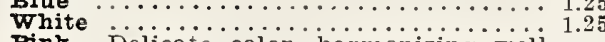

Pink. Delicate color, harmonizing well

with the blue and white ..................

$\$ 7.00 \quad \$ 60.00$

7.00

60.00

$7.00 \quad 60.00$

7.00

7.00

60.00

60.00

$\$ 0.00$

7.00

60.00

60.00

CHEIRANTHUS (Siberian Wallflower).

Allioni. A beautiful rock plant. Dazzling fiery orange flowers, on stems about a foot high. Best used as a biennial as it frequently blooms itsclf to death .....

Iinifolius, Similar to the above, with mauve colored flowers ..................

CHELONE (Shellflower).

Handsome perennials, growing about two feet high, and bearing numerous spikes of large flower heads, Summer and Fall.

Glaba Doz $100 \quad 1000$

white flowers ....................

Iyoni. Heads of showy purplish red

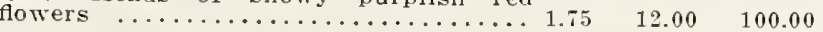

\section{CIMICIFUGA (Snakeroot).}

Racemosa. Handsome species bearing in July and August spikes of pure white flowers: well suited for planting at the back of border, or for naturalizing at $\begin{array}{llll}\text { back of border, or for naturalizing at } & \\ \text { the edge of the woods. } 4 \text { to } 6 \text { feet .... } & 1.75 & 12.00\end{array}$

COREOPSIS (Tickseed).

Grandiflora. An improved variety with large, bright yellow flowers; one of the best hardy plants. Fine for cut flowers all summer long ................... $1.20 \quad 7.00$

60.00

\section{CORYDALIS (Fumitory).}

Ornamental, early-flowering plants, especially useful for shady positions but requiring good drainage.

Bulbosa. Fernlike foliage with spikes of Doz.
purplish flowers; does well in shade...\$4.00 $\$ 30.00$

Cheilanthifolia. Handsome variety with

fernlike foliage and long spikes of yel-

low blossoms, 10 to 12 inches in height

Prefers rich, well drained, stony soil.

Very rare and perfectly hardy; does well

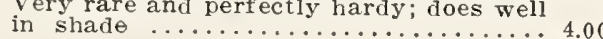

30.00

CONVALLARIA (Lily-of-the-Valley).

Majalis. This popular and fragrant subject repays for being well treated. Grand for massing near shruhs or along shaded borders.

Native Clumps (in Fall only) .......4.00 4.00 .00

1000

CORONILLA (Crown Vetch).

Codonopsis ovata. Twining in habit; 10 to 12 inches high; pale blue flowers; needs protection in Winter .....................

varia. A strong creeper; good for covering rough banks; showy heads of pink and white, pea-sinaped flowers 1 to feet. June-August ............... 2.00

RUCIANELLAA (Crosswort).

Stylosa. Early"fiowering, hardy perennial, suitable for rock work; bright purple, ball-shaped flowers. Height 6 inches. Unique $. \ldots \ldots \ldots \ldots \ldots \ldots \ldots \ldots \ldots . \ldots \ldots$

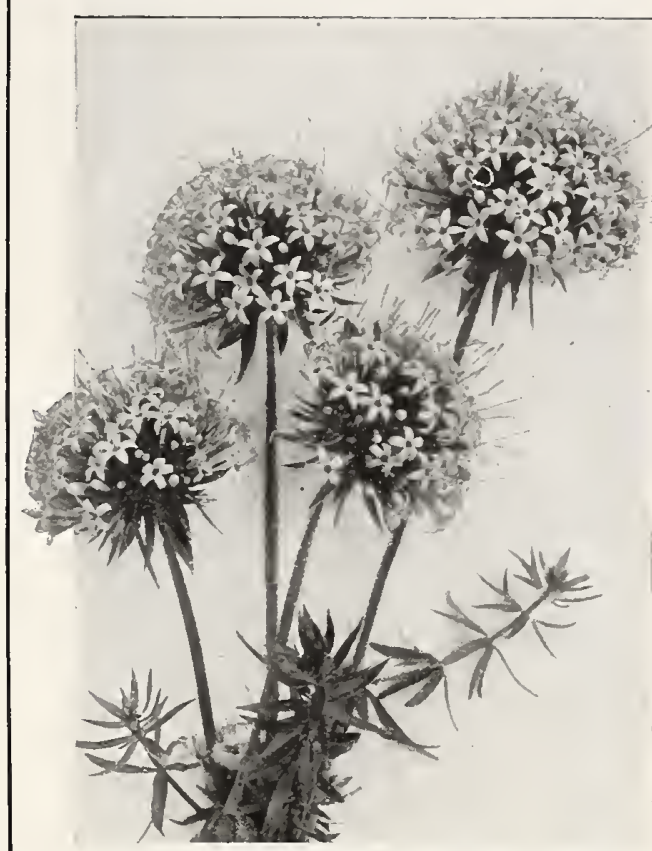

Crucianella Stylosa.

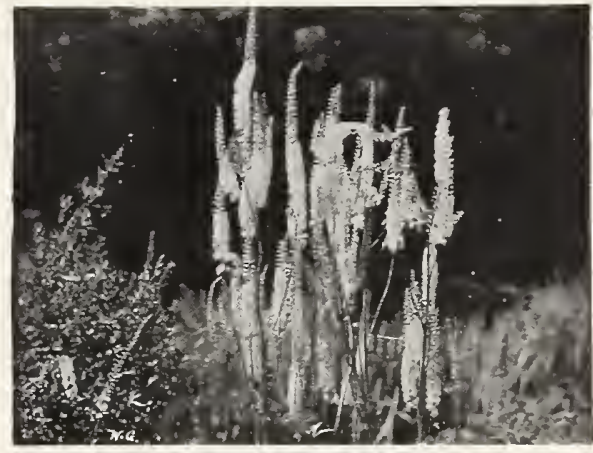

Cimicifuga-Snakeroot.

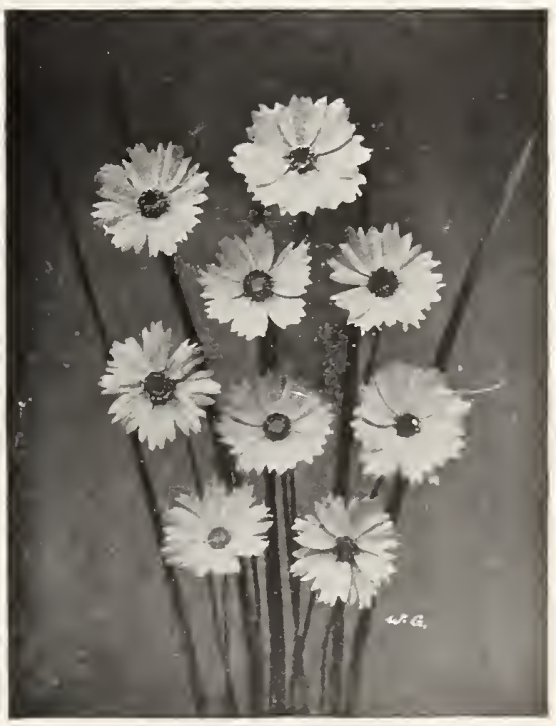

Coreopsis Grandiflora. 


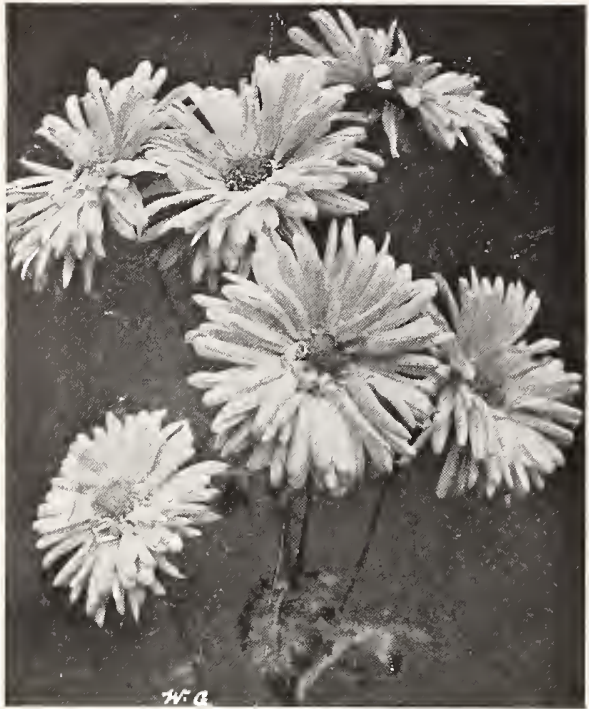

Hardy Chrysanthemums.

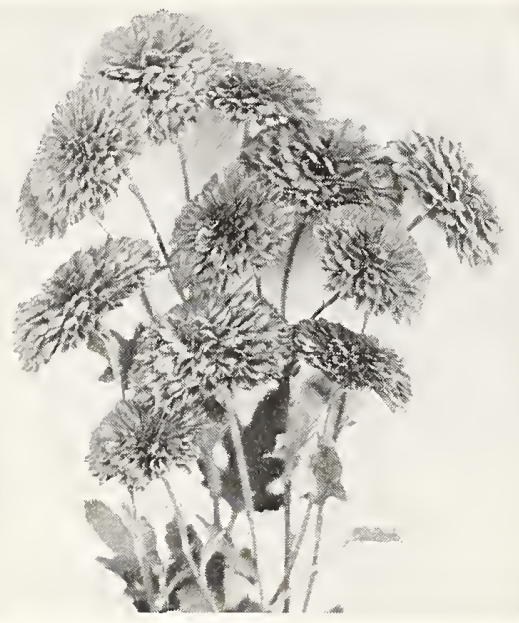

Pompon Chrysanthemums.

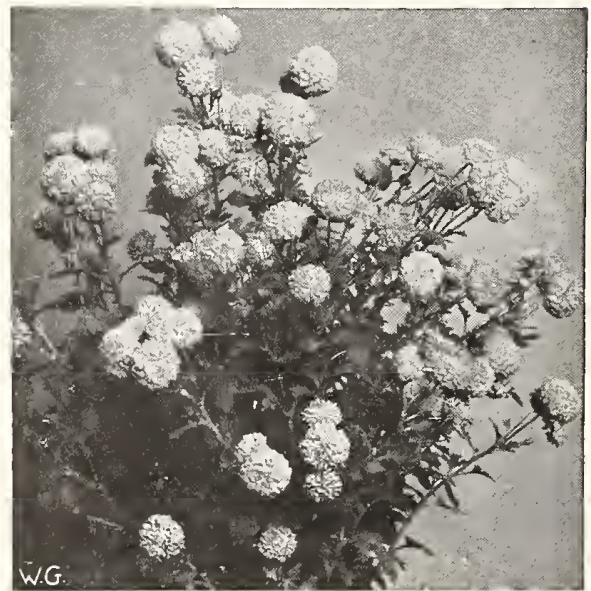

Button Chrysanthemums.

\section{Hardy Garden Chrysanthemums}

The following varieties are perfectly hardy if grown in a place not too wet. After through flowering cut the dead stalks down to two or three inches of the ground and cover with dry leaves.
In the spring, after they start to grow, divide so one shoot will remain for the future plant.

\section{CHOICE NAMED VARIETIES}

The varieties offered below comprise the choicest new hardy outdoor sorts. We have chosen the earliest to bloom, so that the full enjoyment of these best-of-all Autumn flowers may be derived by those in northern territories where Winter comes early.

Plants offered below are from $23 / 4$ inch pots and will be supplied in the Spring.

For Autumn deliveries we offer field grown clumps at

$\begin{array}{rrr}\text { Per } 12 & \text { Per } 100 & \text { Per } 1000 \\ \$ 1.75 & \$ 12.50 & \$ 100.00\end{array}$

We suggest Fall planting in southern states.

EARLY-FIOWERING VARIETIES

(In full bloom from September 15 th on).

Doz. $100 \quad 1000$

Angelo. Beautiful light pink ......\$1.00 $\$ 7.00 \quad \$ 65.00$

Argenteuillais. Scarlet, tipped yellow $\ldots 1.00 \quad 7.00 \quad 65.00$

Brune Poitevine. Deep velvety red .... $1.00 \quad 7.00 \quad 6500$

Carmelite (Glory of Seven Oaks). Golden $1.00 \quad 7.00 \quad 65.00$

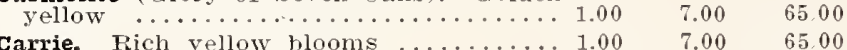

Idolph. A pleasing salmon-pink ..... $1.00 \quad 7.00 \quad 65.00$

Mrs. H. Craig. Yellow, overlaid with $1.00 \quad 7.00 \quad 65.00$

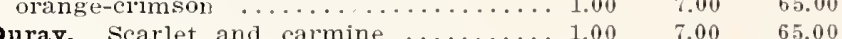

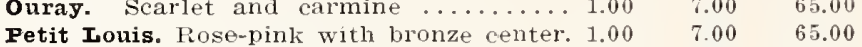

Provence. Rose-pink, tipped rosy red . $1.00 \quad 7.00 \quad 65.00$

skibo. Yellow with reddish center $\ldots .1 .00 \quad 7.00 \quad 65.00$

\section{IATE SUMMER AND EARIY AUTUMN VARIETIES}

(In full bloom from October 1st onward).

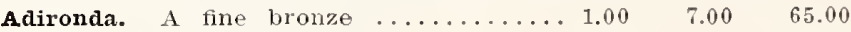

Edna. Creamy white ..................... $1.00 \quad 7.00 \quad 65.00$

Grandiflora. Large golden vellow .... $1.00 \quad 7.00 \quad 65.00$

Harvest Home. Fine golden yellow ..... $1.00 \quad 7.00 \quad 65.00$

Mahogany. Redāish bronze $\ldots \ldots . . .6000$

Mrs. H. Farrison. Medium sized bluish $100 \quad 7.00 \quad 65.00$

pink .................................... $100 \quad 5.00 \quad 65.00$

Mrs. Phillips. Blie Blake. Reddish copper........ $1.00 \quad 7.00 \quad 65.00$

Oconto. Splendid pure white........ $1.00 \quad 700 \quad 65.00$

October Gold. Rich golden bronze ..... $1.00 \quad 7.00 \quad 65.00$

Tints of Gold. Large, beautiful bronze $007.00 \quad 65.00$

wm. Sobey. Fine vellow .............. $1.00 \quad 7.00 \quad 65.00$

Zelia. A fine orange-bronze .............. $1.00 \quad 7.00 \quad 65.00$

\section{MIDSEASON VARIETYES}

(In full bloom from October 15th onvard).

Boston. Beautiful bronzy orange. Tall

and branched ......................... $1.00 \quad 7.00$

Capt. R. H. Cook. Dark rose with brown-

jsh center $\cdots \cdots, \begin{array}{llll} & 1.00 & 7.00 & 65.00\end{array}$

Comoleta. Medium sized pure jellow .. $1.00 \quad 7.00 \quad 65.00$

Firefly. Bright red; very showy ..... $1.00 \quad 7.00 \quad 65.00$

Globe d'or. Fine, small yellow flowers . $1.00 \quad 7.00 \quad 65.00$

Indian. Copperish red ..........................

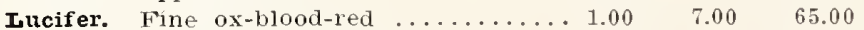

Marie Antoinette. Deep pink ........ 1.00 $7.00 \quad 65.00$

Mitzi. Yellow, with reddish center .... $1.00 \quad 7.00 \quad 60.00$

Mrs. F. F. Bergen. Bright pink ...... 1.00 $7.00 \quad 65.00$

Nellie Kleris. Incurved clear pink .... $1.00 \quad 7.00 \quad 65.00$

Rea Button. Feddish bronze button:

rea Button. free flowering ............... 1.00

Rose Travena. Very large deep rose-pink. 1.00

Ruth. Claret-red .......................

Snowdrop. Pure white button; dwarf .. 1.00

white Dotty. Splendid white........ 1.00 7.00
$7.00 \quad \square .00$

$7.00 \quad 65.00$

$7.00 \quad 65.00$

$700 \quad 65.00$

$00 \quad 65.00$ 
CHRYSANTHEMUMS-Continued.

\section{HARDY OLD-FASHIONED VARIETIES}

We collected from old gardens some of the old-fashioned Chrysanthemums which are really hardy and which bloom in Chrysanthemums which are really hardy and which bloom in often in bloom when the snow is on the ground: are very Often in bloom when the snow is on the ground; are very
showy. 3 to 4 feet high. When in bloom are a perfect mass of flowers.

Old-fashioned Hardy Pink $\ldots \ldots \ldots \ldots \ldots . \quad \begin{array}{ccc}\text { Doz. } & 100 & 1000 \\ \$ 12.00 & \$ 110.00\end{array}$

Old-Fashioned Hardy Red .......... 1.50 $10.00 \quad 90.00$

Old-Fashioned Hardy white ......... $1.50 \quad 10.00 \quad 90.00$

old-Fashioned Hardy Yellow $\ldots \ldots \ldots \ldots .1 .75 \quad 12.00 \quad 110.00$

The above varieties are supplied in strong, field-grown plants

We do not advise the planting of Hardy Garden Chrysanthemums in the Autumn in any locality where the temperature during the Winter, goes ten degrees below the freezing point In southern or other states where this does not happen, we suggest the use of field-grown clumps. Field plants should also be obtained in the late Autumn for propagating during the Winter.

\section{CHRYSANTHEMUM MAXIMUM (Shasta Daisy).}

The improved varieties of Marguerite, all allied to the Shasta Daisy that adorns our fields in the Spring, are among the most useful of our garden flowers. Not only have these flowers been greatly improved in size and form, but there are now early and late blooming varieties which give a succession of long-stemmed flowers so valuable for vase decoration during four months oi the year. Glory of Wayside is a variety worthy of attention, the year. Glory of and has enormous flowers with strong stems. The Shasta Daisy has a yellow center with long, white petals, the slender stems has a yellow center with long, white petals, the slender stems either in the perennial border or as a cut flower. Common kinds like Alaska have been discontinued.

\section{FOR MAY FLOWERING}

Glory of wayside. Abundant flowers and Doz. $\quad 100$

Glory of wayside. Abundant flowers and $\$ 1.50 \$ 10.00$

1000

Leucanthemum flore pleno (Double White Shasta Daisy). Flowers double, pure white, of medium size, excellent for cutting; each plant produces from 30 to 50 flowers; perfectly hardy without any protection. Our latest and best addition to the Shasta Daisies ............. 1.50 10.00

90.00

\section{FOR JULY FLOWERING, ONWARD}

Mrs. C. Lowthian Bell. This magnificent white Marguerite is undoubtedly the largest flowered variety of this class. Flowers frequently measure six inches across, with very broad petals of great substance. Height $2 \frac{1 / 2}{}$ to 3 feet ..... $3.50 \quad 25.00$

Sutton's Perfection. Beautiful flowers, having long, pure whjte petals with small yellow centers A great favorite. Height $21 \%$ feet

\section{FOR SUMTMER AND LATE FLOWERING}

Arcticum (The Arctic Daisy). Among Fallflowering perennials this is a perfect gem. It forms an attractive rosettelike clump of pretty dark green foliage, and in september multitudes of flower stems appear, terminated by pure white

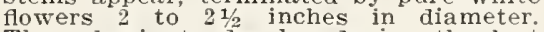
These begin to develop during the last week in September, and continge in good week in september, and continne in good quently into November ............... $1.50 \quad 10.00$

90.00

Etoile d'or. Another of the large-flowered English type, producing the largest and best flowers of any we have ....2.00 $2.00 \quad 15.00 \quad 140.00$

Uliginosum (syn. Pyrethrum). Giant Daisy. Grows 3 to 4 feet high, covered from June to September

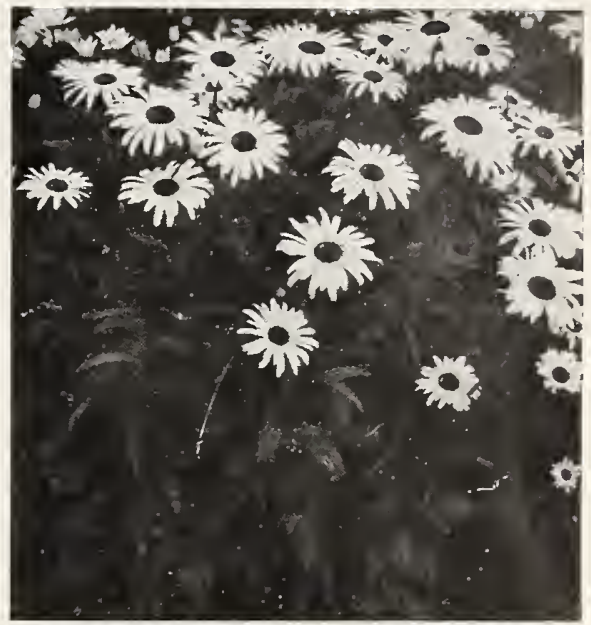

Shasta Daisy, Mrs. C. Lowthian Bell.

This is a very fine cut flower variety.

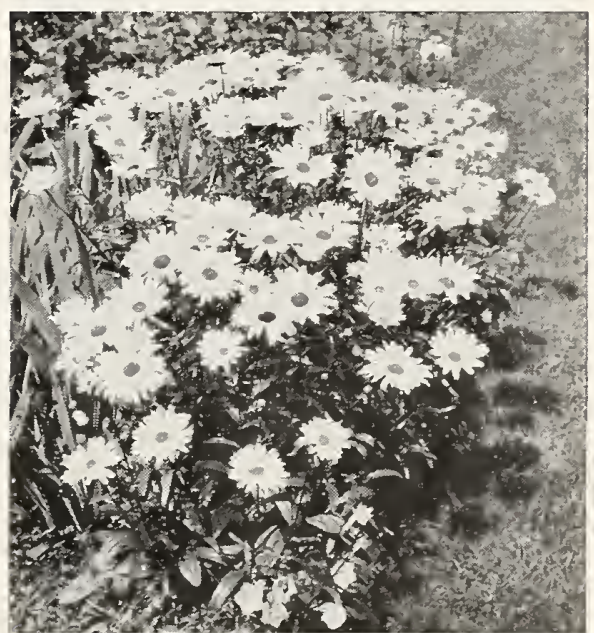

Daisy, Glory of Wayside.

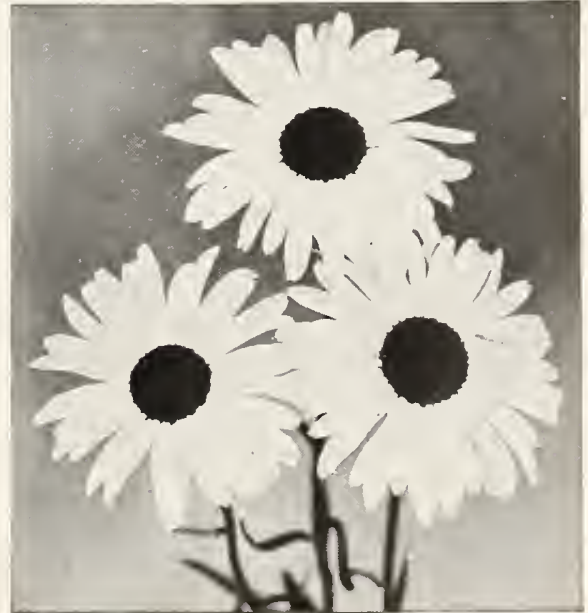

Daisy, Etoile d Or. 


\section{$\begin{array}{llllllllllllllllllllllllllll}T H & E & H & A & Y & S & I & D & E & G & A & R & D & E & N & S & C & O\end{array}$}

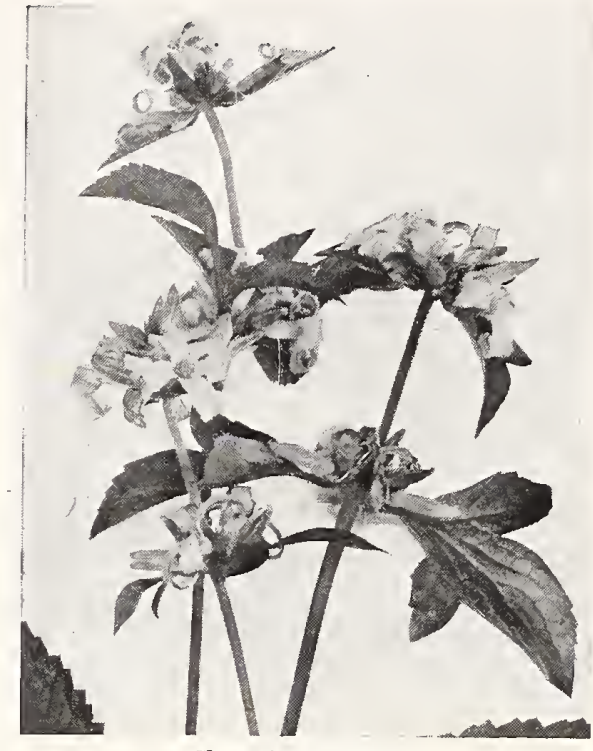

Clematis Davidiana.

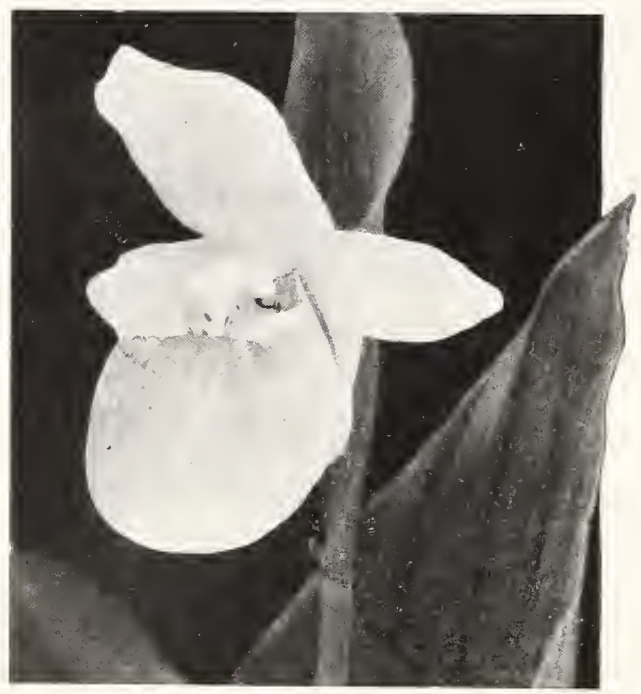

Cypripedium Spectabile.

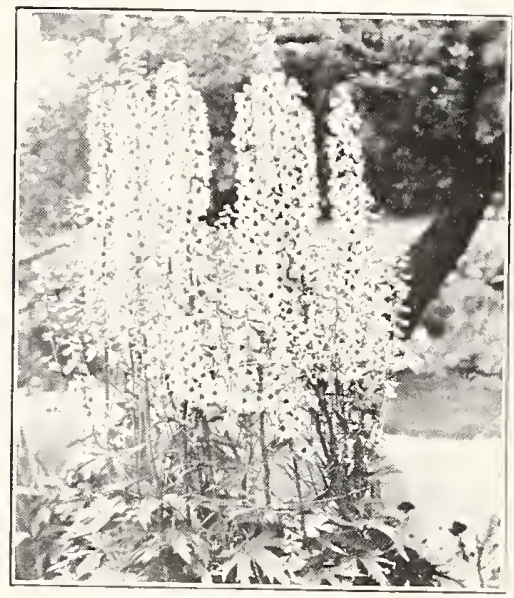

Dalphinium Belladonna.
CLEMATIS, DWARF (Shrubby).

Davidiana. A most desirable variety, Doz. $100 \quad 1000$ with fresh, bright green foliage and tubular bell-shaped flowers of deep lavender-blue during August and September; deliciously fragrant. $21 / 2$ feet. $\$ 3.00 \quad \$ 20.00 \quad \$ 190.00$

Integrifolia coerulea. A good border plant, growing from 18 to 24 inches high, producing its small but interesting por-

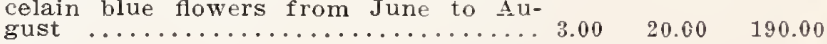

Recta. Grows from 2 to 3 feet high, and produces fragrant, pure white flowers in very large, showy elusters during June and July $3.50 \quad 25.00$

\section{CYPRIPEDIUM (Lady's Slipper).}

Hardy orchids that thrive in a moist, peaty soil, in shade or partial shade; flowers are very interesting with their odd shapes and uncontinon colors and markings.

Acaule (Lady's Slipper; Moccasin Flower) Doz. $\quad 100-1000$ This is often called the Red Lady Slip-

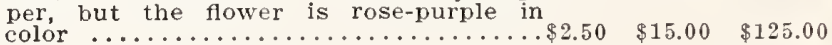

Pubescens (Large Yellow Lady's Slipper). Very much like Parviflorum, only the flowers are larger. This should be planted in a rich bed in which leaf-mold should be a part, in some moist, yet should be a part, in some moist, yet
well drained shady spot. $\ldots \ldots \ldots \ldots \ldots$

Spectabile (Showy Lady's Slipper). The finest and most showy of all our orchids. It grows about two feet high, bearing along the stalk several rather large, roundish leaves, and on top one or two roundish leaves, and on top one or two

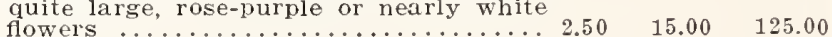

DAPHNE (See Shrubs, page 55).

Price, large plants ....... \$2.50 each.

\section{DELPHINIUM (Larkspur).}

Belladonna. They are our best blue cut flowers, are perfectly hardy and established plants produce a number of spilies, giving three crops during the spiles, giving three crops during the florist for decoratins, the light blue Horist for decorating, the light blue Belladonna combining especialiy well with other flowers. The two-and threeyear-old plants of Belladonna can be vantage

1-year. Light sky-blue ........... $1.30 \quad 8.00$ 2-year. Light sky-blue. Select for
forcing $\ldots \ldots \ldots \ldots \ldots \ldots \ldots \ldots \ldots$

60.00 3-year. Light sky-blue. Select for
forcing $\ldots \ldots \ldots \ldots \ldots \ldots \ldots \ldots \ldots \ldots$

Bellamosa. A dark blue of the tvpe of Belladonna with the color of the old Formosum variety, but not liable to mildew like the latter and of stronger growth.

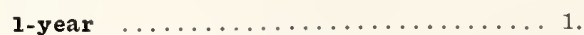

2-year. Select for forcing ........ 1.50

Chinense. A very pretty variety, with fine feathery foliage and intense gentian-blue flowers in open panicles .... $1.50 \quad 10.00$

Chinense album. A pure white form of the above ............................... $1.50 \quad 10.00$

Formosum. The old-fashioned darli blue Larkspur .......................... $1.50 \quad 10.00$

Nudicaule. A dwarf native of California, producing intense orange-red flowers . . 2.00 15.00 


\section{DELPHINIUM - Larkspur}

English Delphiniums are the most beautiful hardy plants in cultivation, for they have such an immense variety of beauty and increase in size, in beauty, and often in quantity, year after year. Some varieties grow 8 feet high in rich soil. They have immense spikes of most beautiful flowers of every imaginable shade of blue, and their season is long; in fact, they will bloom from Spring till Fall.

The culture of Delphiniums is exceedingly simple. They thrive in almost any position, and may be planted at any time of the year, provided that in Summer the plants are not too forward, and that they be well watered if the weather is dry. The soil may be a rich, friable loam, which suits them finely; but any soil, even hot and sand $y$, if well watered and manured, will give excellent results. Placed in lines, as a background to a border, or in groups of, say, three plants at intervals, the effect of the Delphinium is exceedingly fine. A succession of flowers may be expected from Spring to early Autumn, especially if the spikes, which have done flowering early, be cut down to the ground; fresh growth will then be produced which will give blossoms. Watering in Summer will increase size of spike and flower. Topdressing is greatly recommended on certain soils, instead of the bare surface of the ground being left exposed to the sun. Some of the neater dwarf Alpine and other hardy plants may be utilized to plant between and around Delphiniums. Coal ashes strewn over the crowns will protect the plants from slugs through the Winter and Spring. Any garden soil suits the Delphiniums.

\section{Choicest Wayside Gardens Unnamed Hybrids}

Here offered are the newest, the best

Doz. $100 \quad 1000$

and the finest to be secured anywhere. The range of colors varies from the palest shade of blue to the deepest indigo-blue and royal-purple with many intermediary pastel tones of mauve, pink and lavender blendings. Among these new hybrids are flowers of huge size in both single and double forms. This strain has been raised from seed saved from the finest named kinds in creation. Visitors at our nursery proclaim them the best they have ever seen. Those who wish to perfect their already much prized borders cannot afford to overlook these wonderful hybrids

\section{Imported Strain}

(Blackmore and Langdon's).

Doz. 100

1000

Grown from seed of famous named

sorts. Introduced by England's fore-

most grower of Delphiniums.

1-year-old plants

$\$ 2.00 \$ 15.00 \quad \$ 140.00$

2-year-old plants

$\begin{array}{lll}2.50 & 18.00 \quad 170.00\end{array}$

The fine types of Delphiniums unfortunately do not live very long in our country, we therefore advise the planting of one-year-old roots, and in no instance older than two years, so that you may enjoy them the longest possible time.

Plant all hardy plants early and cover slightly the first Winter after planting. Our shipping season opens September 1st. Send your order now.

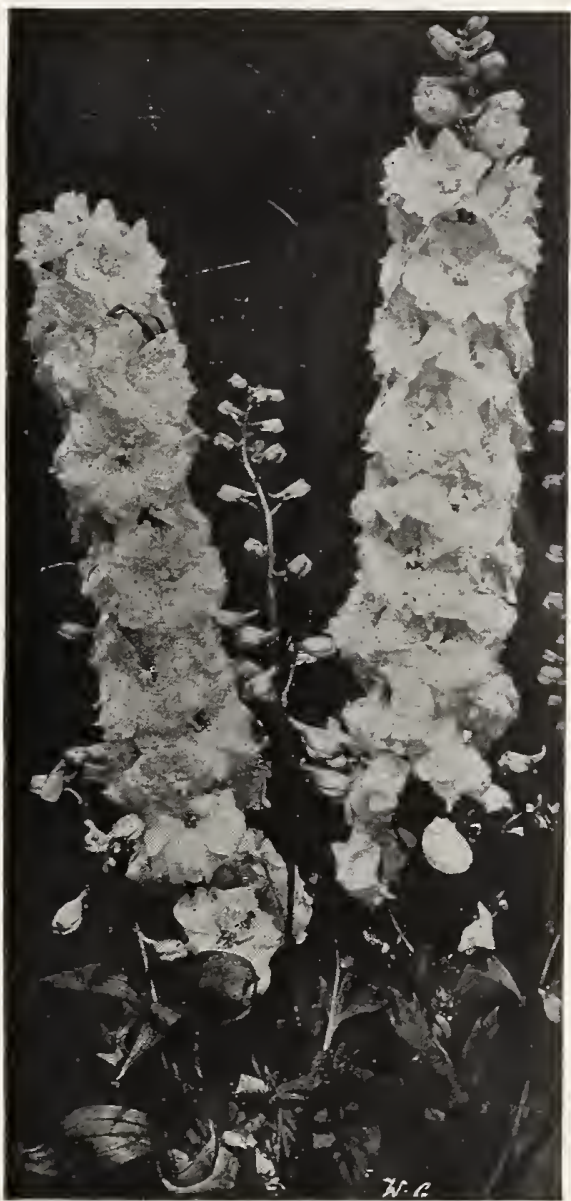

Delphinium, "Wayside Hybrids."

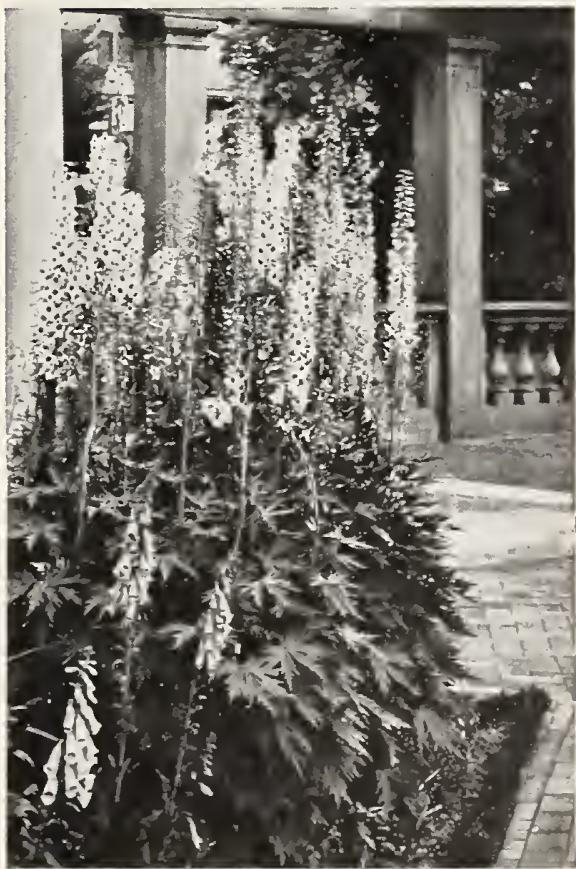

English Delphiniums, Single Form. 


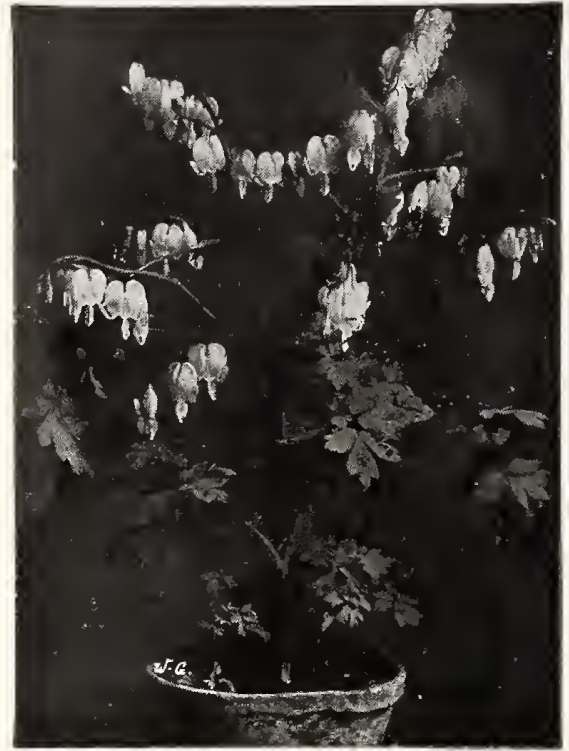

Diely tra-Bleeding Heart.

May be forced to bloom in the house by anyone without any trouble.

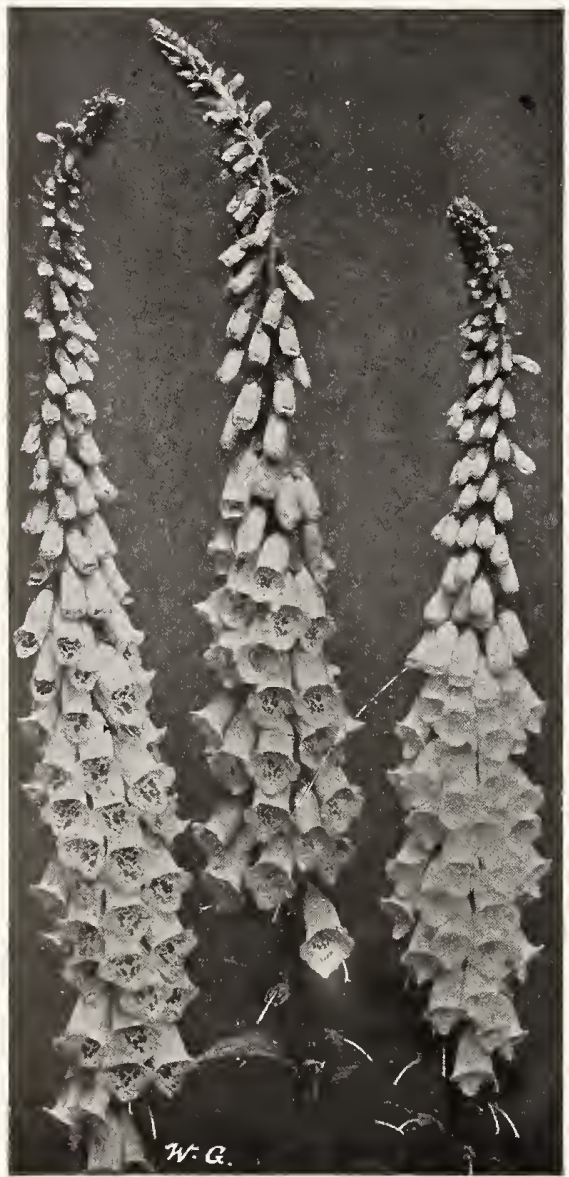

Digitalis, Shirley Hybrids.
DESMODIUM (Tick Trefoil).

Penauliflorum. An exceedingly graceful
shrublike plant covered with purplish

else is in bloom. Strikingly beautiful..\$4.00 $\$ 30.00 \quad \$ 275.00$

\section{DICTAMNUS (Gas Plant).}

The Dictamnus is one of the most satisfactory hardy plants in cultivation, both on account of splendid flowers and its rich, durable foliage.

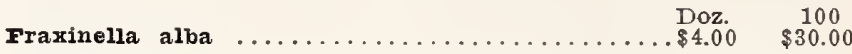

Fraxinella rubra $\ldots \ldots \ldots \ldots \ldots \ldots \ldots \ldots \ldots \ldots . . \ldots 4.00 \quad 30.00$

\section{DIELYTRA OR DICENTRA (Bleeding Heart).}

A hardy perennial with heart-shaped, rose-colored flowers in drooping spikes. The base of the flower is furnished with two sheathlike spurs. One of the best border plants; perfectly hardy and easily cultivated. Flowers in April or May. The Bleeding Heart is one of the choicest members of the old-fashioned gardens. They prefer the shaded nooks in the border.

Iximia (Plumy Bleeding Heart). A dwarfDoz. 100 1000

growing sort, with beautiful finely cut foliage and showy racemes of pretty pink flowers throughout the season. Too much cannot be said for this fine border plant as it is equally at home in full shade or sun and perfectly hardy anywhere. Bailey's "Cyclopedia of American Horticulture" says in description. "The handsomest foliage of any border plant in the entire collection "This va plant in the entire collection," variety of Bleeding Heart is the only kind which will replace the Spectabilis which
is so hard to get. Will grow in any is so hard to get. Will grow

2-year-old $\ldots \ldots \ldots \ldots \ldots \ldots \ldots \ldots \ldots \ldots \ldots \ldots 1.75 \quad \$ 12.00 \quad \$ 100.00$ 1-year-old (strong) $\ldots \ldots \ldots \ldots \ldots \ldots \ldots \ldots 1.50 \quad 10.00 \quad 90.00$

Spectabilis (Bleeding Heart or Seal Flower). An old-fashioned favorite its long racemes of graceful heart-shaped pink flowers are always attractive; it is pink flowers are always attractive; it is at home in any part of the hardy borat home in any part of the hardy borin clumps. Each, $60 \mathrm{c} \ldots \ldots \ldots \ldots \ldots \ldots 4.50 \quad 35.00 \quad 325.00$

\section{DIGITALIS (Foxglove).}

For stately and picturesque beauty it is not to be surpassed, and, planted in masses in the garden among shrubs or naturalized on the edge of woods, in the orchards or along brooks, it is extremely effective and satisfactory. It is a biennial, but, as it renews itself from self-sown seed, it may be treated as a perennial.

Giant Shirley Foxgloves. We now have a Doz. $\quad 100 \quad 1000$ fine lot of field-grown plants of the Giant Shirley Foxgloves. They are a genuine "Shirley" production of extraordinary size and vigor, growing 5 to 6 feet tall. The flower-heads are over 3 feet long, crowded with big, bell-shaped blossoms. Colors range from white and shell-pink to deepest rose, many attractively dotted with crimson or chocolate. Furthermore, they are more apt to be of perennial habit than the old-fashioned Foxgloves, $\$ 1.75 \quad \$ 12.00 \quad \$ 100.00$

Ambigua or grandiflora. 2 to 3 feet. June mbigua or grandifiora. 2 to 3 feet June and July. A hardy plant, with yellowish

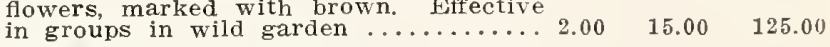

Gloxiniaeflora. 3 to 4 feet. June and July. A popular variety, ranging in color from from rose to deep purple. Robust habit. $1.25 \quad 8.00 \quad 70.00$

Gloxiniaeflora alba. 2 feet. June and July. The white-flowered Foxglove ... 1.25 $8.00 \quad 70.00$

Ianata. Dwarf variety; flowers are a deep purple Dw................... $1.50 \quad 10.00 \quad 90.00$

Mixed Colors. Fine new strain ...... $1.25 \quad 8.00 \quad 70.00$ 


\section{DIANTHUS - Pinks}

\section{HYBRID GARDEN PINKS}

Without the spicy fragrance of the Hardy Pinks a garden is incomplete. Their perfect form and rich coloring make them great favorites for Summer bouquets. June.

Delicata (Double). Beautiful pink, shaded Doz. $100 \quad 1000$ cream $\ldots \ldots \ldots \ldots \ldots \ldots \ldots \ldots \ldots \ldots \ldots \ldots 2.50 \quad \$ 15.00 \quad \$ 125.00$

Elsie. Deep rose-pink, flowers all Sum-
mer $\ldots \ldots \ldots \ldots \ldots \ldots \ldots \ldots \ldots \ldots \ldots \ldots \ldots$

Essex witch. Delicate pink; finely

fringed $\ldots \ldots \ldots \ldots \ldots \ldots \ldots \ldots \ldots \ldots \ldots \ldots 2.50 \quad 15.00 \quad 125.00$

Her Majesty. Very large; purest white . 2.50 $15.00 \quad 125.00$

Manning's Pink. A very free-flowering variety, producing perfectly formed, deep pink flowers; sweet scented $\ldots \ldots$ 2.50 $\cdot 15.00 \quad 125.00$

Mrs. Simpkins. Pure white; sweet scented. $2.50 \quad 15.00 \quad 125.00$

White Reserve. Continuous flowering;

pure white ...............................

\section{NEW CRIMSON HARDY PINK}

Itoile de Iyon. Brilliant crimson, the first of this color in the true hardy Pinks;

grows about a foot high and produces

masses of its rich colored, clove-scented

flowers in May and June .......... $3.50 \quad 25.00$

\section{DIANTHUS ALLWOODI}

\section{(New Perpetual-Flowering Hardy Pink)}

This is a most important addition to our list of perennial plants. This is a most important addion to our list of perennial plants. They are perfectly hardy and hower continuously from early stantial and larger than the old type of Hardy Pinks, and are stantial and larger than the old type of Hardy Pinks, and are scented. All good, thrifty, young plants.

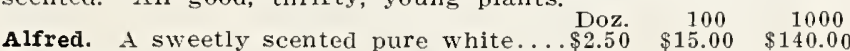
Jean. Pure white with a deep violet- 50 ,

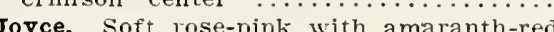

Joyce. Soft rose-pink with amaranth-red $2.50 \quad 15.00 \quad 140.00$

Peggy. Pinkish maloon, delicately fringed. $2.50 \quad 15.00 \quad 140.00$

Robert. Old rose-pink with maroon cen-

$50-00 \quad 140.00$
0.00

Mixed. Single and double; all colors.

Strong, field-grown plants ......... 2.50 $15.00 \quad 140.00$

\section{DIANTHUS PLUMARIUS (Clove Pinks)}

Pink purplish and white, fragrant flowers on long spikes. Handsome, glaucous green foliage. For border or rock garden. It will bloom continuously if flowers are cut off when they begin to fade. Semperflorens flore pleno. Double and Doz. $100 \quad 1000$

single blooms. Blooms throughout the
Summer

\section{DIANTHUS HEDDEWIGI (Japanese Pinks)}

Flowers are very large and of the most brilliant colors, varyins from pure white to the richest crimson, while many are beautifully laced or striped. For bedding purposes they are of immense value during the entire Summer, and they also furnish
elegant flowers for bouquets.

Mixed Varieties

$\begin{array}{ccc}\text { Doz. } & 100 & 1000 \\ \$ 1.50 & \$ 10.00 & \$ 80.00\end{array}$

\section{DIANTHUS BARBATUS (Sweet William)}

The Sweet William is a fine plant which produces great masses of bloom of extremely rich and varied colors. The flowers are lasting and fine for cutting.

Holborn Glory. A very fine auriculaeyed variety; white with a well marked and distinct eye ............................... $\$ 1.258 .00 \quad \$ 70.00$ 工atifolius atrococcineus fi. pl. (Everlasting Hybrid Sweet William). Beautiful Summer bedding variety, producing masses of brilliant fiery crimson

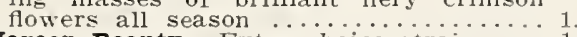

Maroon Beauty. Extra choice strain ...
Newport Pink. Watermelon-pink or sal-

Newport Pink. Watermelon-pink or sal-
mon-rose ...........................
Scarlet Beauty. Rich deep scarlet, bright green foliage; very fine ...... 1.25

White Beauty. Pure white

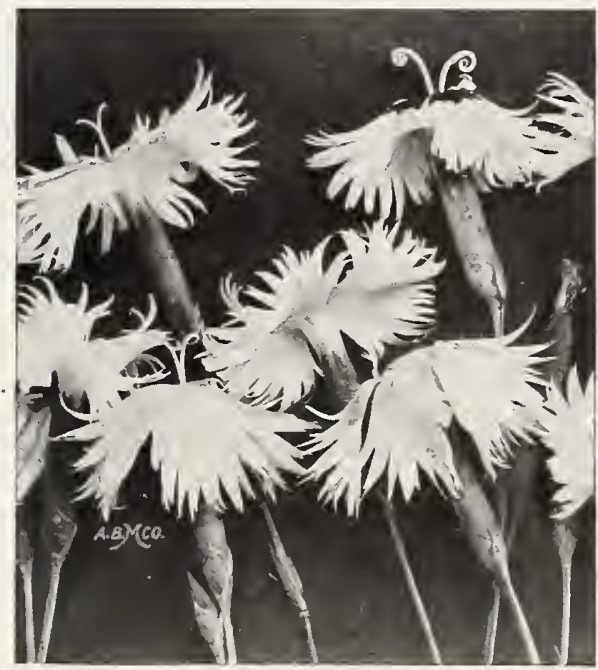

Dianthus Arenarius.

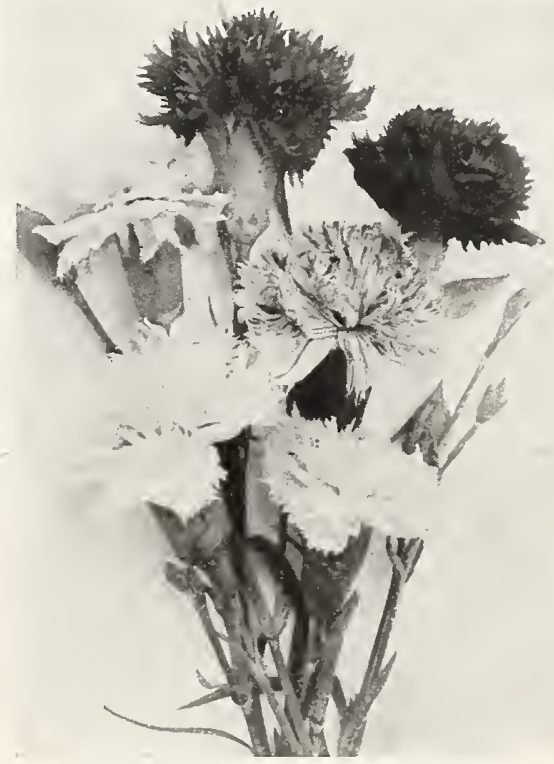

Dianthus Plumarius-Clove Pinks.

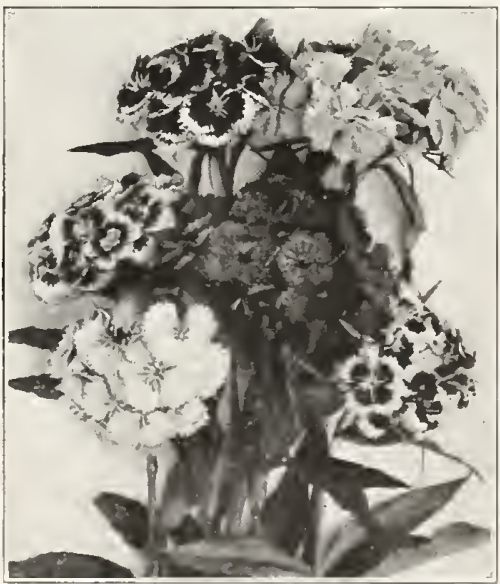

Dianthus Barbatus-Sweet William. 


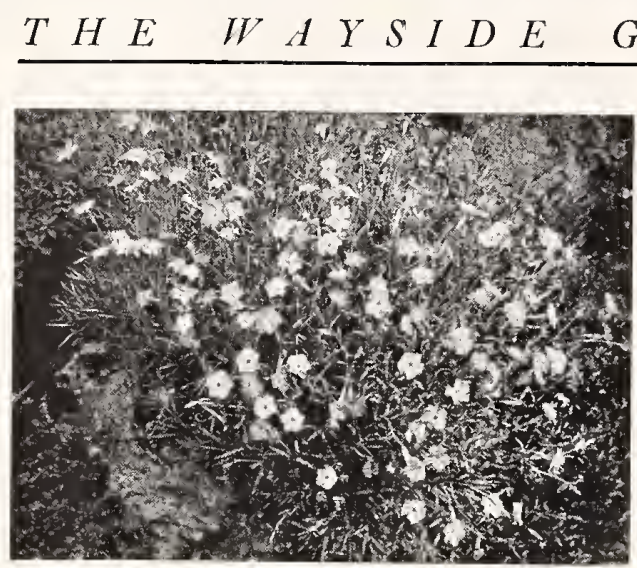

Dianthus Caesius.

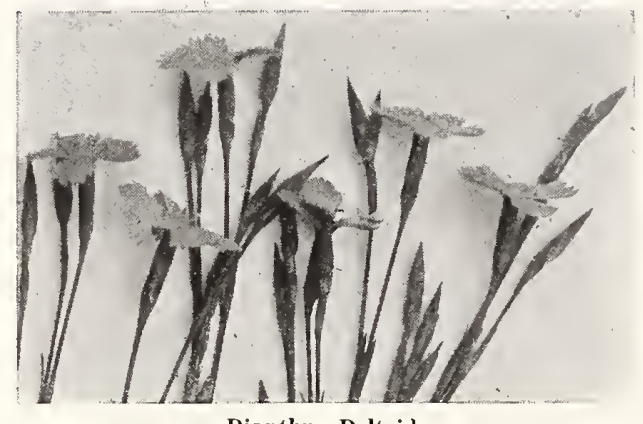

Dianthus Deltoides.

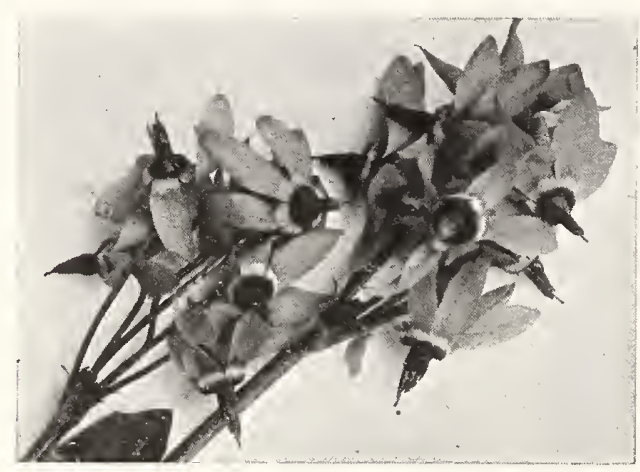

Dodecatheon Meadia.

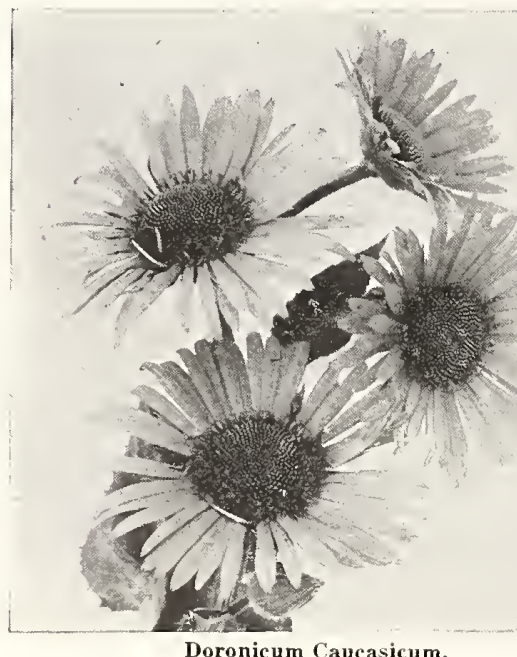

$M E N T O R$,

O H I O

\section{DIANTHUS SPECIES}

\section{VARIOUS VARIETIES}

Suitable for dry rockeries, dry walls or any other hot, dry, sunny spot. Almost all Pinks are of the easiest culture and will thrive in any well drained soil and sunny position. 1000

Arenarius (Sand-Loving Pink). This Pink delights in a sandy soil and sun. Flowers white with carmine ring, deeply fringed and fragrant. Excellent for dry,

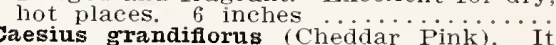
is very compact in growth and makes a cushion of glaucous leaves from which in May, spring the sweet smelling, rose colored flowers It varies as mug as from four inches to ten inches in height. It is easily grown and very fine for the rock sarden

cruentus. Dense heads of flowers on long stems. Deep red. Fine border plant dittle plant with narrow leaves and bearing a profusion of small, erimson flowers during June and July. Easily

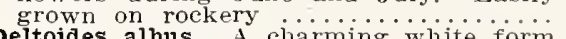

Deltoides albus. A charming white form of the above variety "Giowing erimsonred; a most suriking rock plant ...... speciosus. A free-flowering, lavenderpink variety; flowers are finely cut, giving a lacy effect; wonderfully sweet ing a lacy effect; wonderfully sweet scented, growing anywhere like all other
varieties under this heading; the hotter and dryer the spot the more they are at home

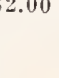

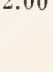

IMeadia (Shooting Star). Native. A pretty, smooth perennial with rose-colored o sometimes white flowers in May or June This is sometimes called "American Cyclamen." It thrives in rich, moist woods,

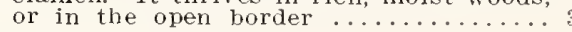

DORONICUM (Leopardbane).

Caucasicum. Large, bright yellow flowers; one of the most effective early Spring-flowering perennials. Effective as a single plant, or in a hardy border It is a splendid flower for cutting, as it carries well and stands a long time in water. They succeed well everywhere. $4.50 \quad 35.00$

DRACOCEPHALUM (Dragonhead).

Very showy border plants when in flower. Hardy. Delight in a cool situation.

Ruyschianum japonicum. Flowers white: central lobe of corolla with a blue border and white spots, might be called a
blue Physostegia. 2 feet $\ldots \ldots \ldots \ldots \ldots 2.50 \quad \$ 15.00 \quad \$ 125.00$

ECHINACEA (Coneflower). (See Rudbeckia Purpurea).

ECHINOPS (Globe Thistle).

Ritro. Interesting and showy thistle-like plants with globular heads of deep dried and renain attractive for a long time. 2 to 3 feet .................

EDELWEISS (See Leontopodium).

\section{EPIGAEA.}

Repens (Trailing Arbutus: Mayflower) Likes acid soil, therefore plant in some place where lime will not hurt it. Strong

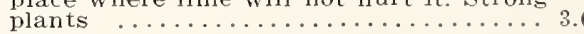

EPILOBIUM (Willow Herb). Angustifolium. White flowers; very
showy among shrubbery. 3 to 4 feet. June-August
osmarinifolium
the above, with red fonali)...................... Similar to are good for cutting ............. 2.00 $15.00 \quad 125.00$

ERIANTHUS (Plume Grass). (See Grasses) 
EPIMEDIUM (Barren-wort, Bishop's Hat). Interesting plants with hard, almost evergreen leaves; excellent
for shady places in border and rock garden; fine plant for edging in shade.

sulphureum. A dwarf-growing plant suitable for a shady position in the rock garden or edge of border, with leathery,

phur-yellow flowers in May ......... \$5.00 $\$ 35.00$

Violaceum. Similar to the above, with reddish violet flowers in May ...... $5.00 \quad 35.00$

\section{ERIGERON (Fleabane)}

A very effective genus of Michaelmas Daisy-like plants usually with pink and purple fowers. They flourish in any garden soil, are indispensable for groups and flower borders, and are excellent for cutting. June to August. Coulteri. Spreading masses of pure white $\$ 1.50 \quad \$ 10.00 \quad \$ 90.00$

Mesa Grande. 18 inches. Violet-blue;

distinct from all others; fine for cutting. $3.00 \quad 20.00$

Speciosus. 2 feet. June and July. Large,

handsome blue flowers, violet tinted and $1.50 \quad 10.00 \quad 90.00$

\section{ERINUS.}

Alpinus. Pretty rosettes of foliage and racemes of rosy purple flowers. A first rate rock plant and also invaluable for establishing on old walls or between steps. 4 inches. May-June ........ 3.50 25.00

ERODIUM (Heron's Bill).

Very choice and valuable race of plants belonging to the Geranium family. Prefer light, rich soil and sunny position. Perfectly hardy. finely cut it has a lacy appearance.

Small pink blossoms, streaked with

black ............................. $\$ 5.00 \quad \$ 35.00$

\section{ERYNGIUM (Sea Holly).}

Finely cut, spiny foliage and thistle-like heads of flowers of a beautful steel blue Very decorative in the hardy border and useful for dry bouquets in Winter.

Doz. $\quad 100 \quad 1000$ true true blue Thistle, with amethyst stems

Glaucum roseum. With heads of pink

Planum. Branching heads of steel-blue flowers; stems and bracts of a glisten-

ing metallic sheen .................. $1.50 \quad 10.00$

ERYSIMUM (Hedge Mustard).

These plants do well in the front row of a border and on dry banks. They like full exposure to sunlight, and in the Spring months are completely covered with bright flowers. Pulchellum (Fairy Wallflower). Dwarf
plant with sulphur-yellow flowers. 6

EULALIA (See Grasses).

EUPATORIUM (Hardy Ageratum).

Ageratoides (Thoroughwort). A useful border plant of strong, free growth, 3 to $3 \frac{1}{2}$ feet high, with minute white flowers in dense heads; splendid for $\begin{array}{lllll}\text { cutting. August and September } \ldots . . . & 1.50 & 10.00 & 90.00\end{array}$

Coelestinum. A pretty hardy plant, with light purple flowers similar to the Ageratum; in flower from August until frost.

18 to 24 inches. Good cut flower .... $1.50 \quad 10.00$

EUPHORBIA (Milkwort).

Corollata (Flowering Spurge). Showy and useful native plant growing about 18 inches high, and bearing from June ers with a small green eye $\ldots \ldots \ldots \ldots \ldots .1 .75 \quad 12.00 \quad 100.00$

Myrsinites. A pretty prostrate species,

bluish foliage, with crowded heads of

yellow flowers ................ 2.00 $15.00 \quad 125.00$

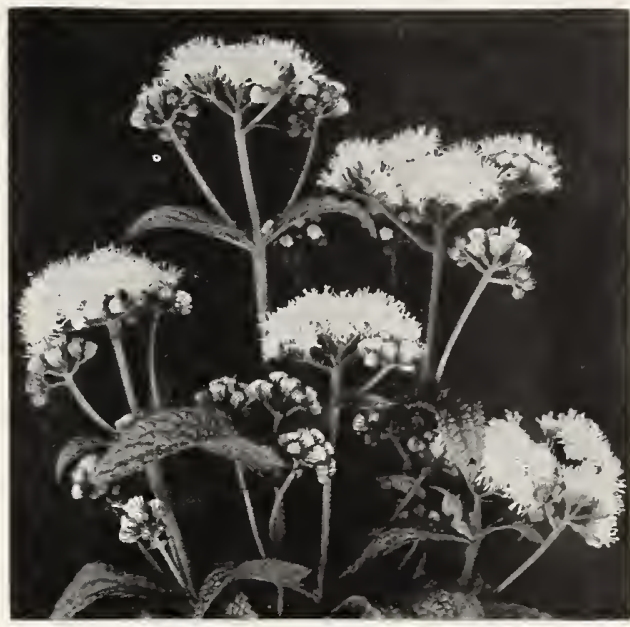

Eupatorium Coelestinum.

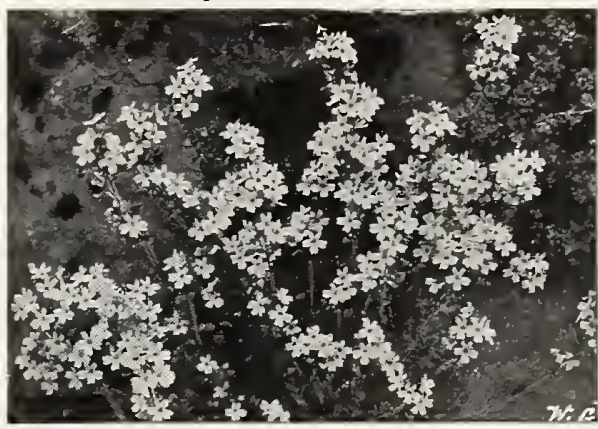

Erinus Alpinus.

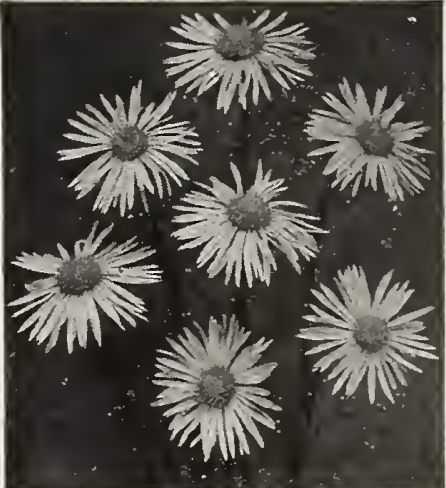

Erigeron.

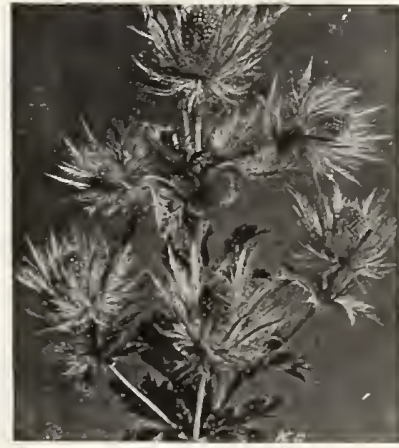

Eryngium. 


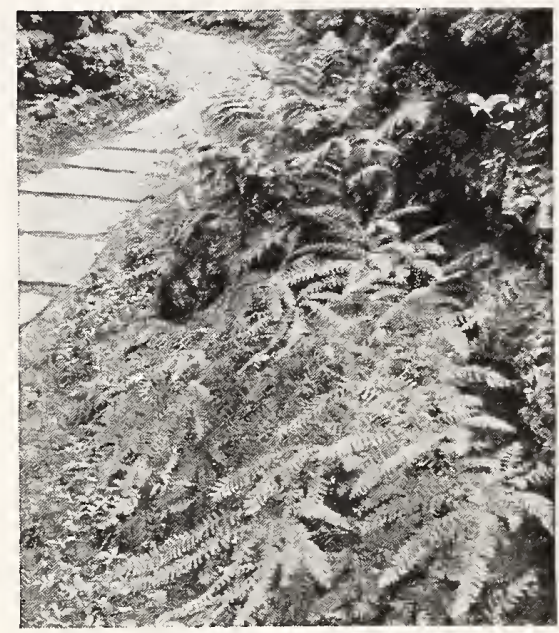

Adiantum Pedatum.
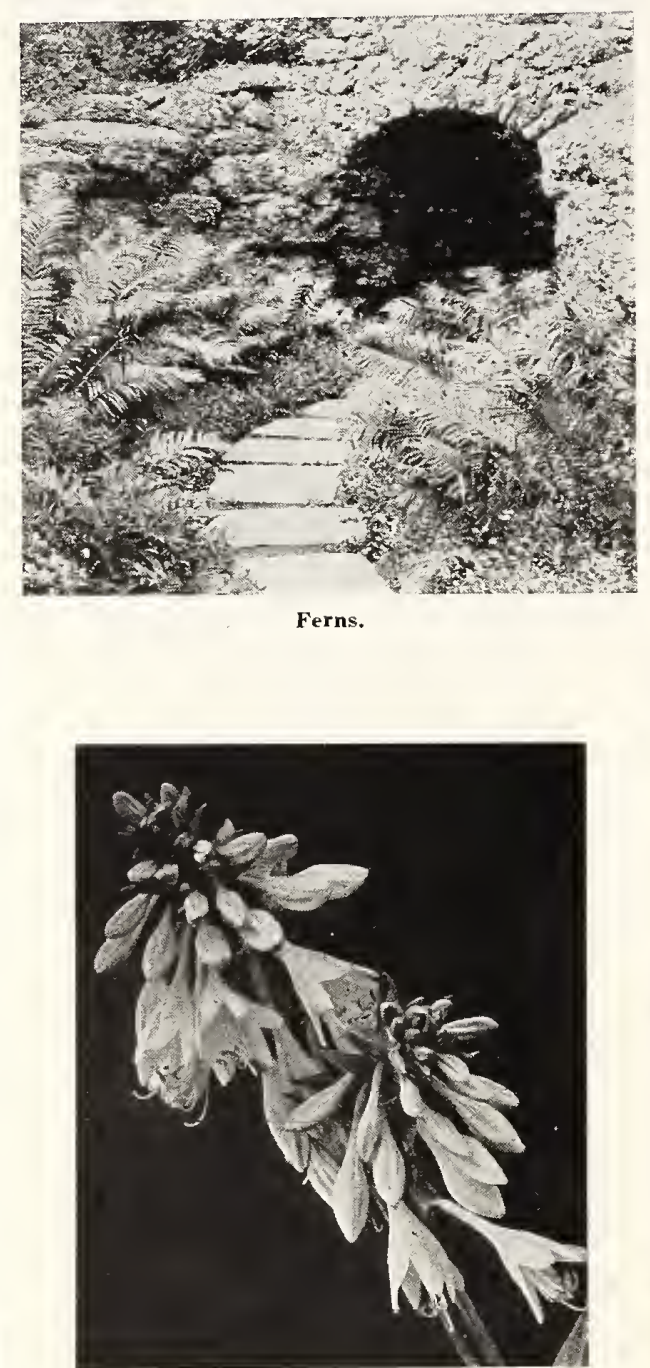

Funkia Glauca.

\section{FERNS - Hardy Varieties}

The cultivation of Hardy Ferns is remarkably simple. All they want is a light alluvial soil, a little loam and peat or leaf-mould sufficient to keep the soil light and open, plenty of moisture, position varying from partial to deep shade. The Aspleniums and many others will grow on walls, chinks of rocks, etc. Many will revel in full sunshine in any ordinary border. There is scarcely a garden or even a back yard where Ferns cannot be grown successfully Anyone commencing with a few specimens will soon be induced to go on collecting until he has made a feature both interesting to himself, and also to all who see them.

Adiantum pedatum (Fardy Maidenhair Doz. $100 \quad 1000$ Fern). Mlost attractive of our native Ferns: blaci stems with delicate green

green $\$ 2.50 \quad \$ 15.00 \quad \$ 125.00$

Aspidium acrostichoides (Wood Fern). (Polystichum). An evergreen species with deep green, divided fronds. Should be planted in a shady position. 12
inches .......................... $1.75 \quad 12.00 \quad 100.00$

Aspidium spinulosum (Tryopteris spinulosa). Spinulosa Woodfern. An ever-

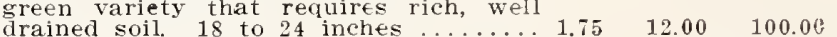

Asplenium filix foemina (Lady Fern). Grows in shade or sun. Large and handsome. 3 feet $\ldots \ldots \ldots \ldots \ldots$............... fronds, drooping at tips, with bright cinnamon colored spores at end of fronds; a very conspicuous variety .... punctilobula). Hay-scented or Gossamer Fern. Grows well in either sun or shade. 18 to 24 inches. Very erect with broad fronds, of a soft, woolly texture, $\begin{array}{rrrr}1.75 & 12.00 & 100.00\end{array}$

Onoclea sensibilis (Sensitive Fern). Requires wet places either in sun or

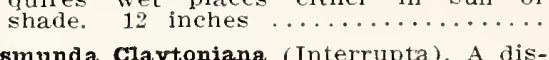

Osmunda Claytoniana (Interrupta). A disfoline vely a

brown spores in middle of fronds .....

Regalis (The Royal Fern). Wonderful in damp, marshy places, where its rich yelmake very striking subjects ............

struthiopteris germanica (The Ostrich Fern). A very graceruling 2 to 3 feet high

$1.75 \quad 12.00 \quad 100.00$ $2.00 \quad 15.00 \quad 125.00$

woodsia obtusa. Large rosettes of curious hoary foliage. Fronds one foot in length; very free growing

FEVERFEW (Matricaria).

Iittle Gem. A most useful border plant and valuable summer cut flower, with large, double, white flowers. June until Getober. 18 to 24 inches.

FOXGLOVE (See Digitalis).

FUMARIA (See Corydalis).

FUNKIA (Plantain Lily).

The Plantain Lilies are among the easiest plants to manage; their broad, massive foliage makes them attractive subjects for the border even when not in flower. They succeed equall well in sun or shade.

Doz. $\quad 100 \quad 1000$

Coerulez. Broad green leaves; blue flow- $\$ 2.00 \$ 15.00 \$ 125.00$

Glauca. A very pretty Japanese species,

with distinctive bluish foliage ...... 5.00 40.00

Subcordata grandiflora. Very large pure white, lily-shaped, fragrant flowers in

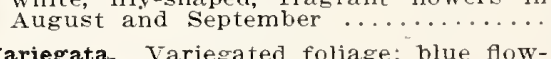

variegata. Variegated foliage; blue flow- $1.75 \quad 12.00 \quad 100.00$ 


\section{GAILLARDIA - Blanket Flower}

Improved English Strain. We consider the Gaillardia one of the most desirable hardy plants in eultivation, and our strain of these brilliant Howered plants to be the finest extant. Though such an ornamental addition to the herbaceous border, the perennial Gaillardia is content with extremely simple treatment Dig the soil deeply and enrich with well-rotted manure We recommend the Gaillardia for bedding purposes as well a as well as for border Gailardias have thriven through droughts, they seem hardy to need water. profusion from June to November and the greater the drought and scarcity of other fower's the more the utility of the perennial Gailiardia is demonstrated. No more beautiful and brilliant sight can be imagined than a large bed of Gaillardias, Some of the varieties of our improved strain measure fully 5 inches in diameter.

Dazler. Introduced in England two years Doz. $100 \quad 1000$ ago. Large, dull red flowers; very fine

variety $\quad \ldots \ldots \ldots \ldots \ldots \ldots \ldots \ldots \ldots \ldots \ldots \ldots \ldots \$ 2.00 \quad \$ 15.00 \quad \$ 125.00$

Choicest Mixed Colors ............ $1.35 \quad 9.00 \quad 80.00$

GALEGA (Goat's Rue).

Showy plants of the easiest culture and very useful in the hardy border. They form very bushy plants with attractive foliage and pea-shaped flowers. Fine for cutting.

$\begin{array}{llll}\text { Offinalis. } & 100 & 1000\end{array}$

fine double pink variety; rather rare $\$ \$ 2.00 \quad \$ 15.00 \quad \$ 125.00$

GENTIANA (Blue Gentian).

Andrewai. One of the most fascinating native plants. The flowers, which are tightly closed, are borne at the top of a stem from 6 to 8 inches long, and are an intense deep blue. Blooms best in inoist places. July and October ....... 2.00
Asclepidea ................. 3.00

Thibetica. Very hardy variety; creamy

white $\ldots \ldots \ldots \ldots \ldots \ldots \ldots \ldots \ldots \ldots \ldots \ldots 2.00 \quad 15.00$

15.00

20.00

GERANIUM (Crane's Bill).

A.rgenteum. Silvery leaved variety: good for hot, dry places in rock or wall gar-

den ....................................

Tbericum. Handscme serrated foliage. Large, lilac-blue flowers, blooming all Summer; compact, bushy plants. 18

inches $\ldots \ldots \ldots \ldots \ldots \ldots \ldots \ldots \ldots \ldots \ldots \ldots 1.50 \quad 10.00$

15.00

Pratense. Large blue flowers in pairs on

plant for border ...................... 2.00 15.00

Pratense album. Very handsome white variety of the Meadow Crane's Bill ...... 2.00

Sanguineum. Attractive foliage and bright crimson flowers; 18 inches ........... 2.00

Sanguineum album. Fine lock plant; white form of the above ......... 2.00 15.00

\section{GEUM (Avens).}

Coccineum Mrs. Bradshaw (Chiloense). A splendid new variety, with large, double flowers of a fiery red, blooming nearly all Summer. Peculiarly attractive. is inches $\ldots \ldots \ldots \ldots \ldots \ldots \ldots \ldots \ldots \ldots . \ldots \ldots 1.50 \quad 10.00$

Lady stratheden. A new introduction of great merit. Rich golden yellow blossoms, counterpart of G. Mrs. Bradshaw. Fine for hardy garden .............. $1.75 \quad 12.00 \quad 110.00$

GILLENIA (Bowman's Root).

Trifoliata. A strong growing plant; admirable for the border or for use in connection with shrubs, with handsome trifollate foliage and numerous white flowers tinged with pink. 3 feet ........ 1.7
125.00

185.00

125.00

125.00

90.00

125.00

125.00

125.00

125.00

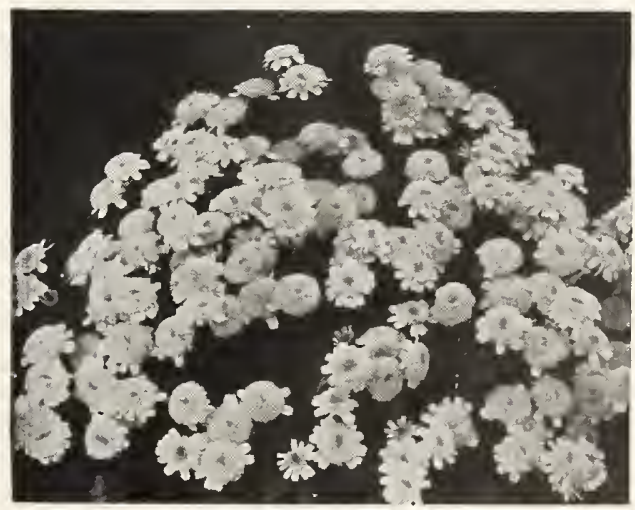

Feverfew-Matricaria.

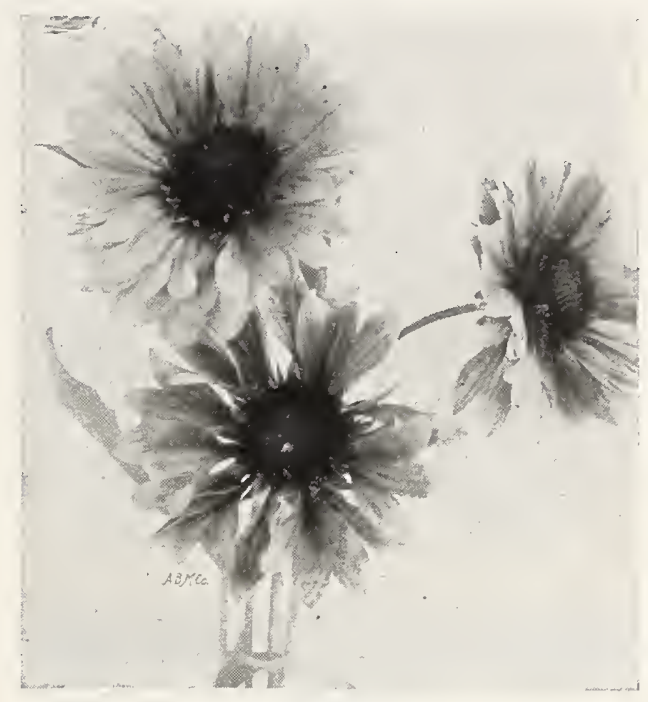

Gaillardia.

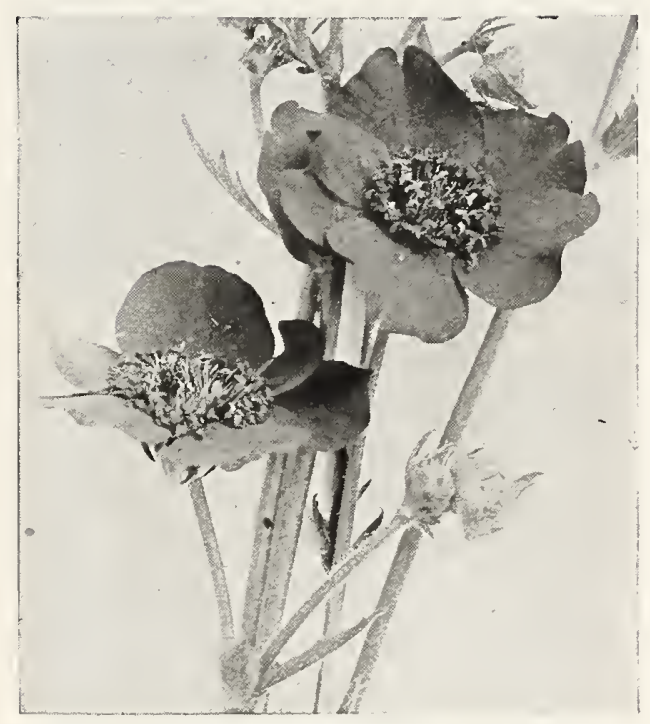

Geum, Mrs. Bradshaw. 


\section{$\begin{array}{llllllllllllllllllllllllllll}T H & E & W & A & Y & S & I & D & E & G & A & R & D & E & N & S & C & O\end{array}$}

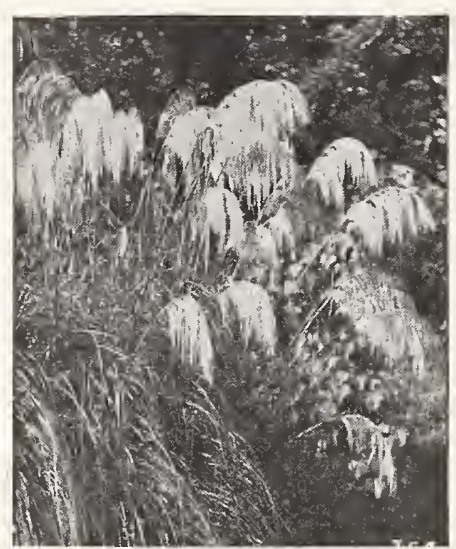

Pampas Grass.

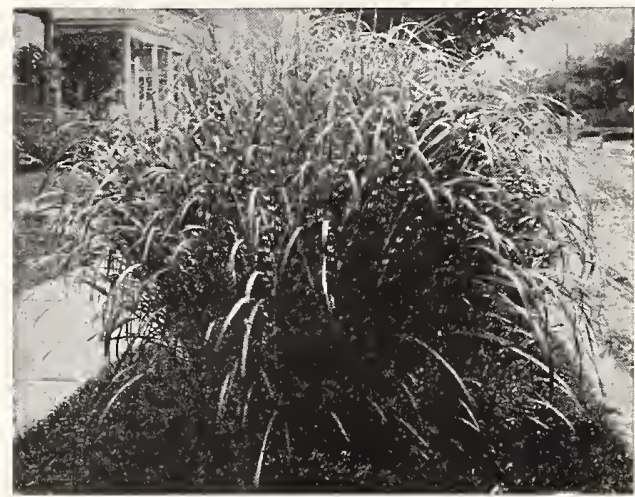

Eulalia Zebrina.

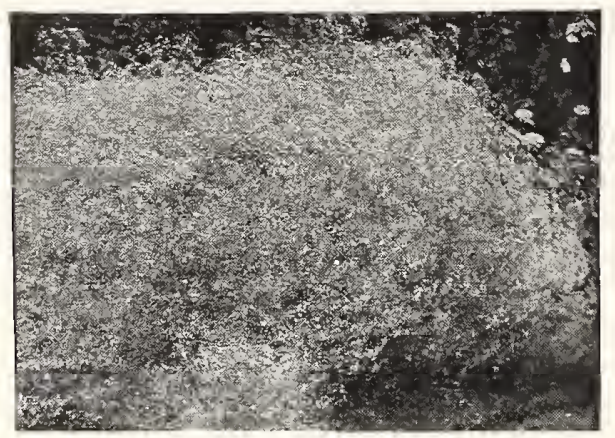

Gypsophila Paniculata.

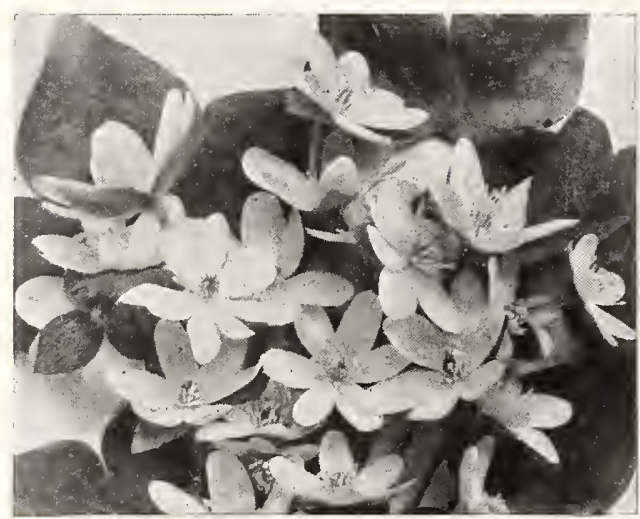

Hepatica.
GRASSES (Hardy Ornamental)

The ornamental Grasses can be used with telling effect in borders, large beds, or by the margin of ponds and lakes. They are often used with small shrubs and medium sized trees in wide borders. The Eulalias planted singly on lawns where the soil is deep and rich, take care of themselves and grow very rapidly into large specimens. In large, round beds, with ornamental Grasses as the principal feature, the effect is heightering plants near the margin.

Flyzmus glaucus (Blue Lime Grass).

Doz. $\quad 100$

1000

Handsome Grass with narrow glaucous

silvery foliage. Well adapted for the

Erianthus ravennae (Plume Grass or Hardy pampas). 10 to 12 feet high, frequently throwing up 30 to 50 flower

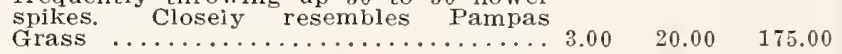

Fulalia gracillima univittata (Japan Rush). Graceful habit, with very narrow foliage: of a bright green color with a silvery midrib. 6 to 7 feet $\ldots . .25 \quad 1.25 \quad 8.00 \quad 70.00$

Eulalia japonica. Long, narrow, graceful green foliage, and when in flower the $\begin{array}{lllll}\text { green foliage, and when in flower the } & & \\ \text { attractive plumes are } 6 \text { to } 7 \text { feet high. . } 1.50 & 10.00 & 90.00\end{array}$

Eulalia japonica variegata. Very ornamental; Jong, narrow leaves, striped
green, white, and often pink or yellow. $1.75 \quad 12.00$

Eulalia japonica zebrina (Zebra Grass). The long blades of this variety are marked with broad, yellow bands across the leaf. It makes a very attractive specimen plant for the lawn. 6 to 10

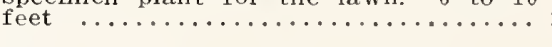

Festuca glauca (Blue Fescue Grass). 12 to 15 inches. Ornamental Grass. Grown for dense tufts of very narrow bluish leaves. Used for edgings or for contrast with darker foliage. Desirable for
rock garden ..................... $1.50 \quad 10.00$

Pennisetum japonicum (Fountain Grass). A beautiful Grass whose flower heads are produced in the greatest profusion. Color rich makogany, conspicuously tipped with white $\ldots \ldots \ldots \ldots \ldots \ldots \ldots$ $2.50 \quad 15.00 \quad 125.00$

Phalaris arundinacea variegata (Tarieinally striped with white: very ornamally striped with white; very orna-

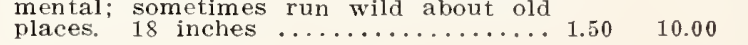

90.00

GYPSOPHILA (Baby's Breath).

Very branching or spreading, slender plants, with scant foliage when in bloom. Of easiest culture in open, rather dry places. Desirable where a mass of delicate, misty bloom will fill in a bare place.

Paniculata compacta. When in bloom in Doz. $\quad 100$ 1000 August and September it forms a symmetrical mass 2 to 3 feet in height and as much through, of minute white flow-
ers having a beautiful gauzelike appearers having a beautiful gauzelike appear$\$ 1$

Paniculata flore pleno. A light and graceful cut flower, compatible with all others, no matter of what shape or color; masses of minute double white flowers. guarantee all plants sold to be double). 5 .

Repens. A beautiful trailing plant for the rockery, with clouds of small, white and pink flowers in July and August . . . . $1.50 \quad 10.00$

Rokejeka (Acutifolia). Rose colored "Baby's Breath." Tall, graceful grower, and a wonderful cut flower ........ $1.50 \quad 10.00$

HEPATICA (Wood Anemone).

Coerulea. A pretty nativc, Spring-flowering plant, with bluc flowers; prefers ing plant, with bluc fowers; prefers shade, but will do fairly well in an open situation in moist, rich loam. Whe offer
large, established clumps, each consisting of 6 to 12 large crowns ........ $1.25 \quad 8.00$ 


\section{HELENIUM (Sneezewort).}

Tall growing plants closely allied to the sunflower; bearing in late summer and Fall great masses of large, daisy-like flowers in shades of yellow and orange.

Autumnale superbum. Doz. $100 \quad 1000$ deep golden yellow flowers in late Sum-

mer. Grows 5 to 6 feet high $\ldots \ldots \ldots \ldots \$ 1.75 \quad \$ 12.00 \quad \$ 100.00$

Autumnale rubrum. A splendid new rariety; deep ox-biood-red, changing to terra cotta. 5 to 6 feet. September $\quad \begin{array}{lllll}\text {. } & 1.75 & 12.00 & 100.00\end{array}$

Bigelovi. Quick growing, branching plants 2 to 3 feet; quite showy during August yellow flowers; brown centered ..... 2.00 $15.00 \quad 125.00$

Fumilum magnificum. Large, golden yellow flowers; one of the noost floriferous $\begin{array}{llll}\text { and useful border plants in cultiration. } 3.00 & 20.00 & 180.00\end{array}$ Riverton Beanty. Purs lemon-yellow,
with large dise of purplish black ....2.00 Riverton Gem (New). Old gold, suffused with bright terra cotta, changing to wallflower-red. August to October ... $2.00 \quad 15.00 \quad 125.00$

HELIANTHUS (Hardy Sunflower).

The perennial Sunflower should always be planted in masses, where they may have plenty of room a pla backgrounds of shrubbery or naturalized in orild gardens or woodlands. They produce a or hatuffect inposibl to describe In combination produce a grand effect impossible to describe. In combination with hardy Asters, where broad color effects are wanted in producing an unlimited supply of flowers for decoration.

Acutifolins. An extremely beautiful Octo-

er variety, with large flowers of a de-
lightful shade of golder yellow $\ldots \ldots \ldots 1.50$$\$ 10.00 \quad \$ 90.00$

Maximiliani. The latest of all. Golden yellow flowers in graceful spravs in October. Fine for cutting. 6 feet .... $1.50 \quad 10.00 \quad 90.00$

Mollis. An improved variety of Helianthus lactiflorus; of taller growth and having larger flowers. A decided improvement and most beautiful sort ............. $1.50 \quad 10.00$

Multiflorus fl. pl. Clear yellow: closely

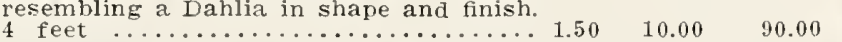

Sparcifolius. The best of the Summerblooming varieties of hardy Sunflowers Flowers 3 inches in diameter and freely produced. Plant grows 3 to 4 feet high, and spreads rapidy. Fine for the border, and for planting among shrubs ... $1.50 \quad 10.00$

HELIANTHEMUM (Rock or Sun Rose).

Low-growing evergreen plants, forming broad clumps, and which during their flowering season, July to September, are hidden by a mass of bloom; for the front of the border, the rockery, or a dry, sunny bank

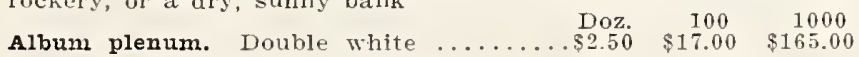

Bride. Single white, silvery foliage ... $2.50 \quad 17.00 \quad 165.00$

Clara Middleton. Single, rich orange ... $2.50 \quad 17.00 \quad 165.00$

Fireball Bright single scarlet ........2.50 $2.50 \quad 17.00 \quad 165.00$

Macrantha. Single, yeilow ............ 2.50 $17.00 \quad 165.00$

Mrs. Earle. Double, scarlet .........2.50 $2.50 \quad 17.00 \quad 165.00$

Mutabile. Golden yellow, single ....... $1.75 \quad 12.00 \quad 100.00$

Praecox. Single, yellow, silvery foliage.. 2.50 $17.00 \quad 165.00$

Rhodanthe carneum. Large, pink flowers.

silvery foliage ....................50 $17.00 \quad 165.00$

Rose Queen. Large single pink flowers .. $2.50 \quad 17.00 \quad 165.00$

Sudbury Gem. Single, crimson-bronze ... $2.50 \quad 17.00 \quad 165.00$

Choice Mixed Varieties ............. $1.50 \quad 10.00 \quad 90.00$

Helianthemums belong to the finest border or rock plants, but they should be trimmed back before planting as they are otherwise hard to establish. We offer also 3 -inch pot plants ready to bloom in the same colors at the additional charge of 5 cents per plant. Specify pot plants when ordering.

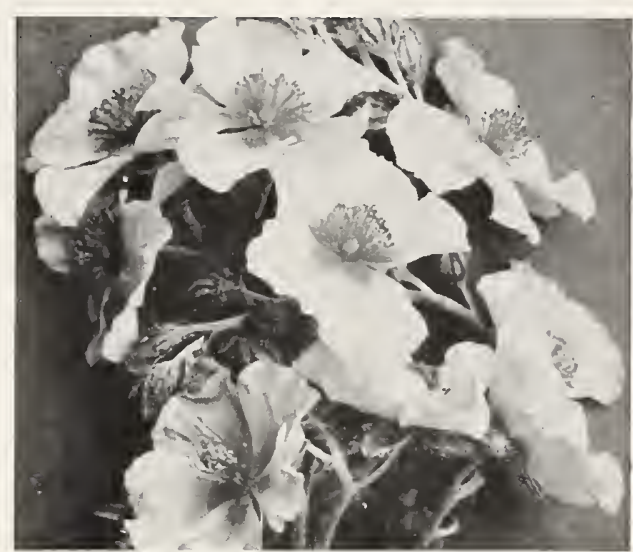

Helenium. Close up of fowcrs.

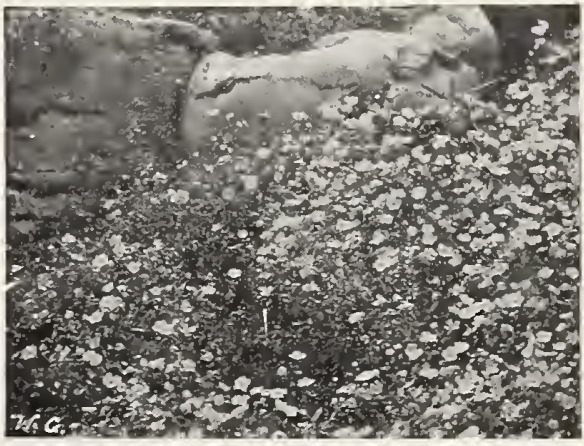

Helianthemum Growing in Rock Garden.

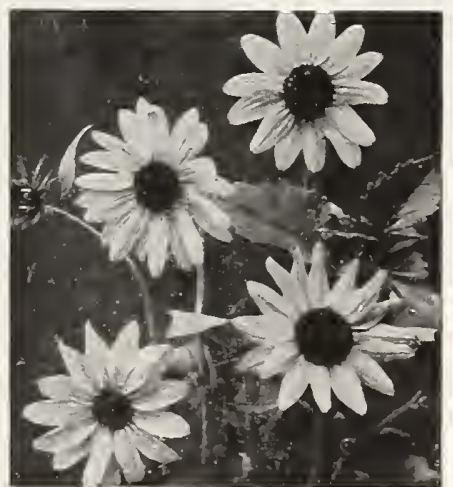

Helianthus.

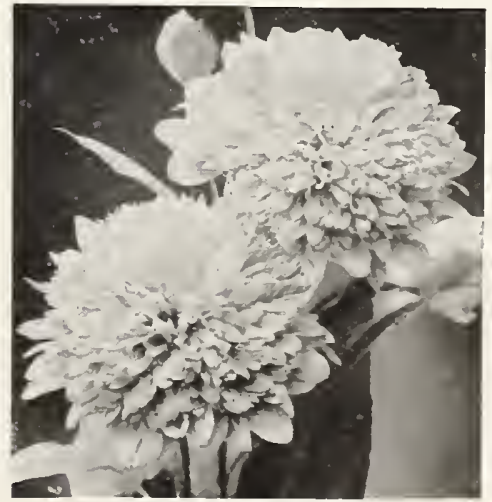

Helianthus Multiflorus ff. pl. 


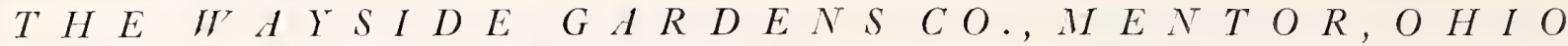

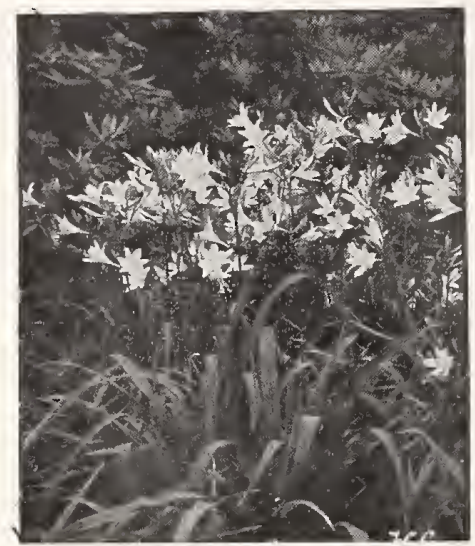

Hemerocallis Thunbergi.

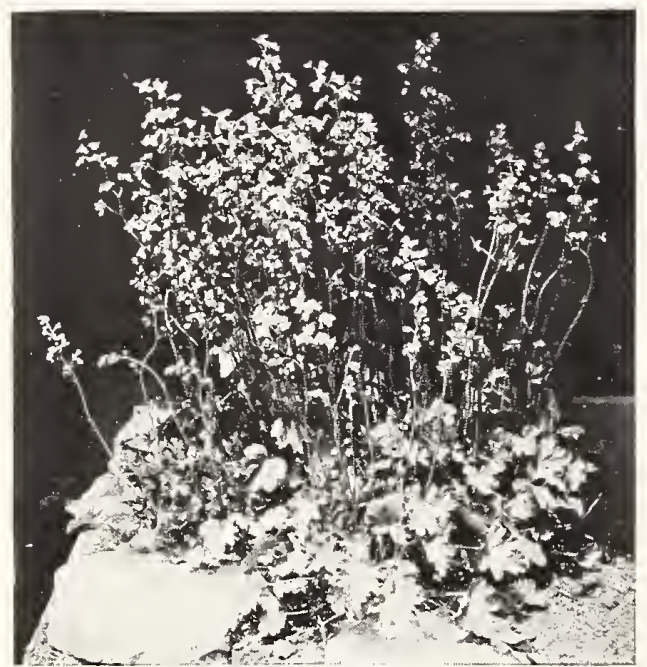

Heuchera Sanguinea.

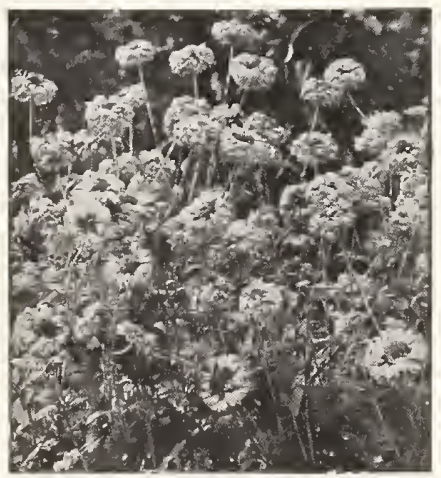

Heliopsis.

\section{HELIOPSIS (Hardy Zinnia).}

Similar in general habit to Helianthus, but commencing to flower earlier in the season. July and August. Of dwarfer habit, rarely exceediug 3 feet in height. Very valuable for cutting:.

Pitcheriana A desirable voz. $100 \quad 1000$ flowers are of a beautiful deep golden

yellow, about two inches in diameter.

yellow, about two inches in diameter,

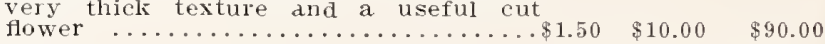

Scabra excelsa. A new variety with very rich chrome yellow flowers, turning to a bright yellow as they mature. These are almost double, having from 4 to 5 rows of petals, and are produced very profusely. The plant is about 3 feet high and from nid-July to the end of

$\begin{array}{lllll}\text { September makes an effectire display } & \ldots & 2.00 & 15.00 & 125.00\end{array}$

HEMEROCALLIS (Yellow Day Lily).

Hemerocallis have long been favorites in our garden, and are always included in any list cf the most popular hardy plants. All of the varieties of Hemerocallis are desirable and beautiful. The tall, graceful, grass-like foliage is very handsome and sets off the charming lily-like flowers very effectively. They look particularly well naturalized along streams or on moist banks, and will thrive most Iuxuriantly in shade.

Dr. Regel. Handsome, rich orange-yellow Doz. $100 \quad 1000$

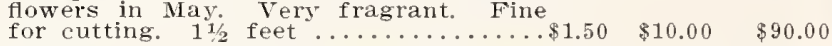

Flava (Lemon Lily). Sweet scented, clear,

full yellow; $21 \%$ feet. Flowers in June. 1.75 $12.50 \quad 115.00$

Florham. A strong grower, 3 to $31 / 2$ feet high, large, trumpet-shaped flowers; ich, golden yellow, with Indian yellow mark-

ings. June and July $\ldots \ldots \ldots \ldots \ldots \ldots \ldots .2 .50 \quad 15.00 \quad 125.00$

Fulva (Brown Day Lily). Coppery orange, shaded crimson. 3 feet. July $\ldots \ldots \ldots . .50 \quad 1.50 \quad 10.00 \quad 90.00$

Kwanso. Large, double-flowered variety with. rich golden bronze flowers ...... 2.50 $15.00 \quad 140.00$

Middendorfi najor. A very striking variety, with huge rich, orange-yellow

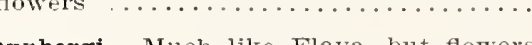

Thunbergi. Much like Flava, but flowers ill July a month later and 6 to 10 inches of the upper portion of the flower scapes are thickened and flattened $\ldots .1 .25 \quad 8.00$

HESPERIS (Sweet Rocket).

Matronalis. 2 to 3 feet. June and July. Fragrant purple flowers in showy spikes. Desirable for wild garden, shrubbery or mixed border ...................... $1.25 \quad 8.00$

HEUCHERA (Coralbells).

Beautiful plants for front row of borders with slender, fairy like spikes of richly colored flowers; most striking in the garden and light and graceful for cutting.

Brizoides. We have thoroughly tested this new Heuchera and find it one of the most desirable hardy plants introduced in many years. It has the same foliage and habit as Heuchera sanguinea, but the color is not so brilliant, though five the color is not so briflant, though five or six times as many Howers are pro- $\$ 3.00 \quad \$ 20.00 \quad \$ 180.00$

Convallaria. Dwarf in habit: free-flowering and easily grown; good shades of $3.00 \quad 20.00 \quad 180.00$

sanguinea. 12 to 18 inches. June to September. Flowers bright crimson; very free-flowering. Nice for cutting. Ex-

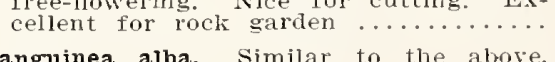
$\begin{array}{lll}3.00 & 20.00 \quad 180.00\end{array}$

\section{NIW HYBRIDS}

Sanguinea Mixed Fybrids. All shades of red and coral. pink, etc. This is our new mixture which is highly spoken of because of its fine coloring, large flowers, and free-flowering habit of the ers, and free-flowering habit of the 


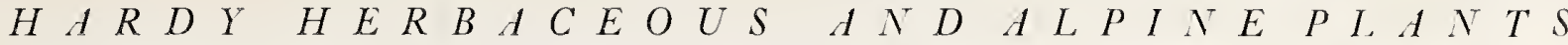

\section{HOLLYHOCKS - Althea Rosea}

The Hollyhock is an old garden favorite, full of sentiment and association with a distant past. It is a plant of strong, vigorous growth and noble aspect, with elegant camellia-like flowers that form perfect rosettes of the most lovely shades of color. They require a deep, rich soil and a sunny corner, but will repay by their gorgeous and lavish bloom all the attention bestowed upon them. Painters choose Hollyhocks as subjects for floral paintings oftener than any other flower. We suppose the reason for this is that artists have a keener appreciation of beauty than other people, and recognize that the common single Hollyhock is one of the most stately, picturesque and beautiful plants in the world. Nothing can be more effective than a large group of single Holithocks, and once planted they will literally take care of themselves even if planted in the grass. We know of patches that have not been cultivated or disturbed in any way for twenty rears some people rhink or disturbed in any way for twenty years. Some people think double Hollyhocks are more beautiful than single. They are mistaken, although the doubles are beautiful, but inclined to following summer.

$\begin{array}{llll} & \text { Doz. } & 100 & 1900\end{array}$

Apple Hlossom .................. $\$ 1.35 \quad \$ 9.00 \quad \$ 80.00$

Bright Rose $\ldots \ldots \ldots \ldots \ldots \ldots \ldots \ldots \ldots .1 .35 \quad 9.00 \quad 80.00$

Dark Purple $\ldots \ldots \ldots \ldots \ldots \ldots \ldots \ldots .1 .35 \quad 9.00 \quad 80.00$

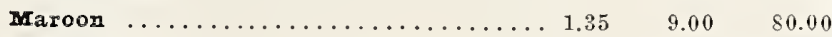

Newport Fink $\ldots \ldots \ldots \ldots \ldots \ldots \ldots \ldots .6 .35 \quad 9.00 \quad 80.00$

Pale rilac $\ldots \ldots \ldots \ldots \ldots \ldots \ldots \ldots \ldots .1 .35 \quad 9.00 \quad 80.00$

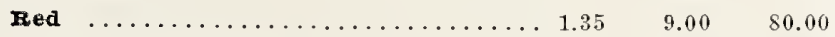

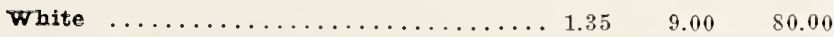

White with purple base ........... $1.35 \quad 9.00 \quad 80.00$

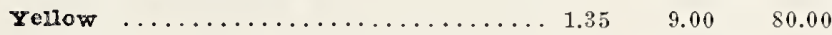

The above shades in mixed colors,
all at $\ldots \ldots \ldots \ldots \ldots \ldots \ldots \ldots \ldots \ldots \ldots \ldots \ldots$

New Allegheny. Immense semi-double

flowers, with fringed edges $\ldots \ldots \ldots \ldots$....... $1.25 \quad 8.00 \quad 75.00$

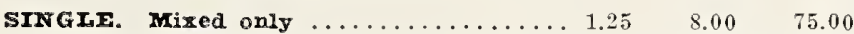

(Our Hollyhocks are free from disease and rust. Clean, strong, one-year-old stock; two-year-old plants are never sent out, as they are not satisfactory).

\section{HIBISCUS (Mallow).}

Mallow Marvels. A robust type of upright habit, producing an abundance of flowers of enormous size in all the richest shades of crimson, pink and white.

New Giant-Flowering Marshmallow. A Doz. $\quad 100 \quad 1000$ wonderfully improved form of our greatRosemallow, in which not only the colors have been greatly intensified, but in which flowers of enormous size, frequently 10 to 12 inches in diameter, have been dereloped. Equally at home in all positions, having the same vigor in dry and wet ground; perfectly hardy and are very floriferous, blooming from andy in July until late in September. They are the most beautiful and hardy of all herbaceous plants, their dignified spikes of baceous plants, their dignified spikes of for large groups and mixed borders. We offer three distinet colors.

Red, Fink or white and Crimson Eye. Strong, 3-year-old .............. $\$ 150 \quad \$ 10.00 \quad \$ 90.00$

Red, Pink or white and Crimson Eye. Strong, 2-year-old ................. $1.25 \quad 8.00$

Mixed Colors. 2-year-old ............ $1.25 \quad 8.00$

Mixed Colors. 4-y.ear-old elumps ..... $1.50 \quad 10.00$

\section{HYACINTHUS CANDICANS.}

Twenty to thirty white, pendent, bellshaped flowers on stalks 3 to 4 feet high. Blooms early and till late Fall. One of the best of all hardy bulbs for the her-

baceous border

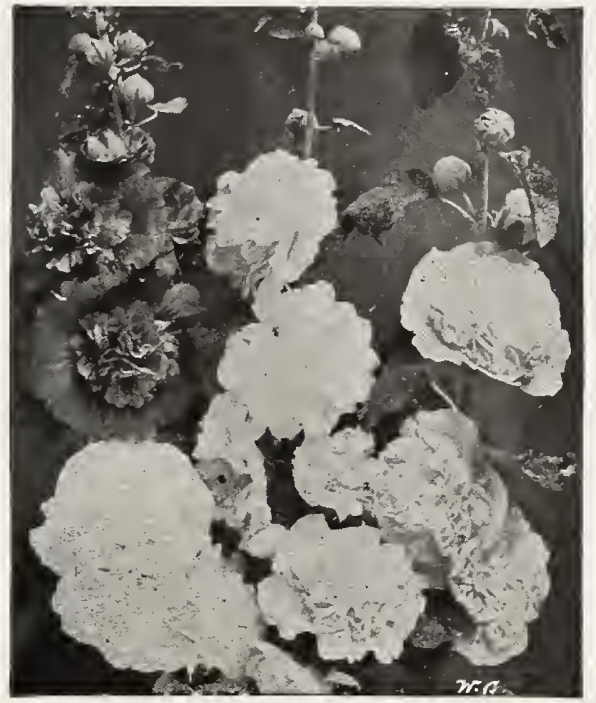

Double Hollyhocks.

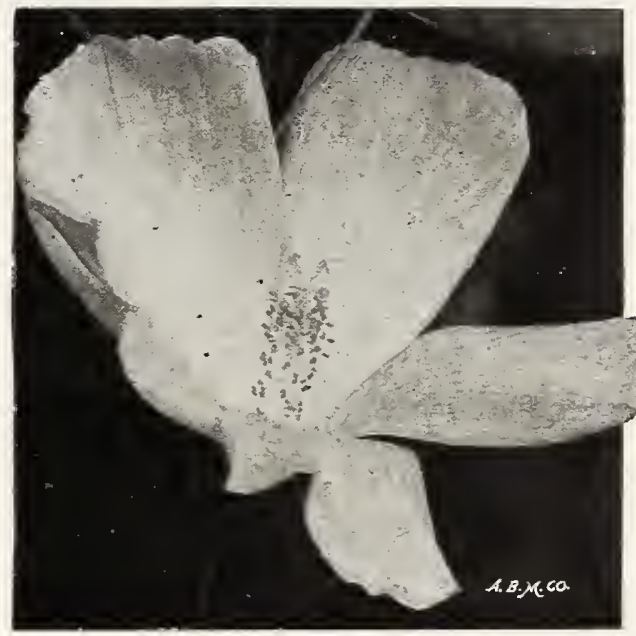

Hibiscus.

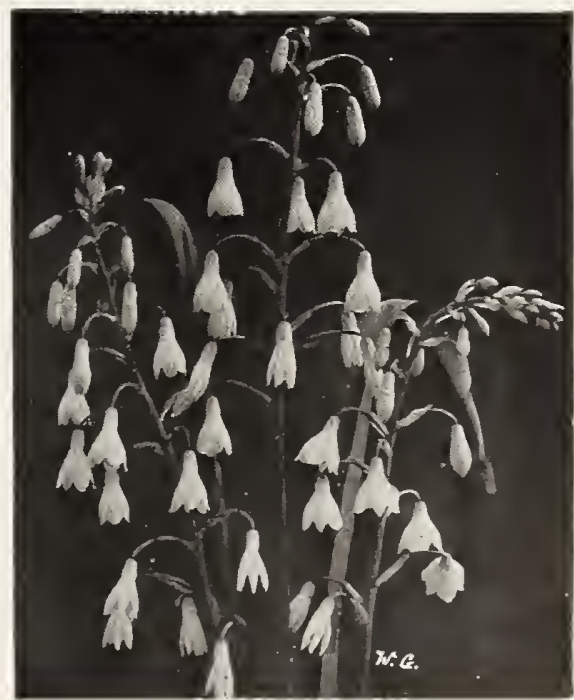

Hyacinthus Candicans. 


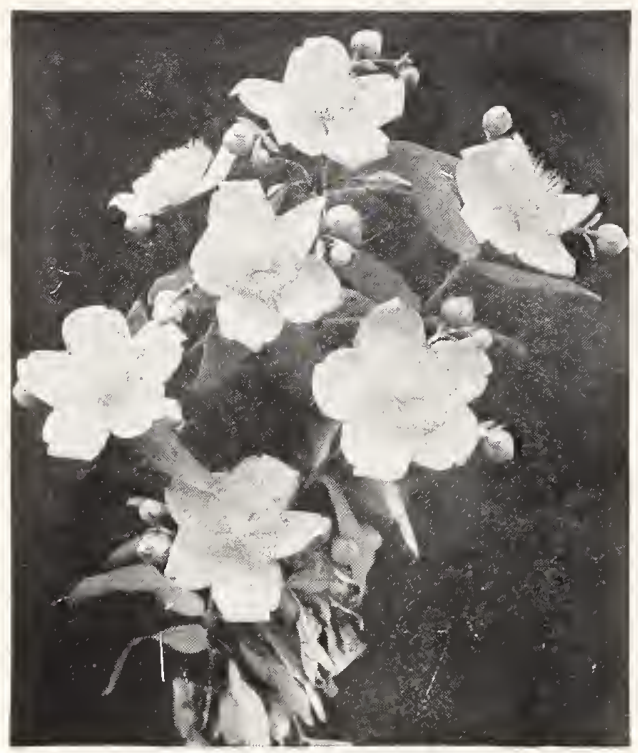

Hypericum Moserianum.

Good for foundation planting.

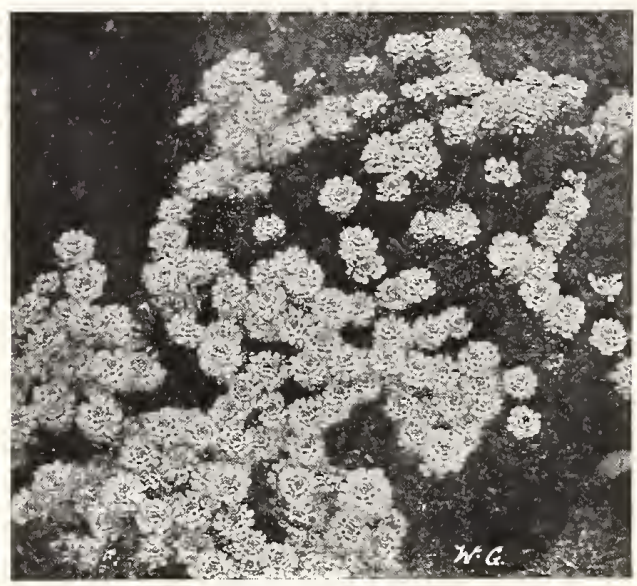

Iberis Sempervirens.

Excellent for edging walks.

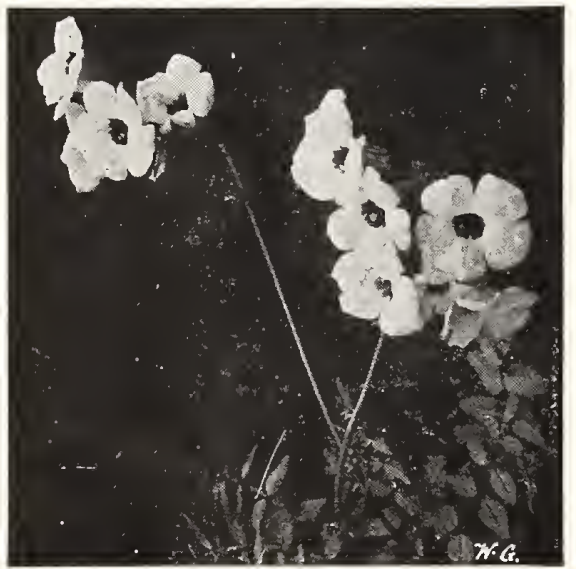

Incarvillea.
HYPERICUM (St. John's Wort).

Calycinum. Similar to the other two vaDoz. $\quad 100$ 1000 rieties, except that it is dwarf in growth; makes underground lunners which, when they come up, produce a beautiful carpet of green covered with large yellow blossoms. Is really a

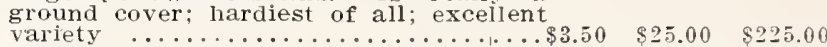

Fenryi. The same as Moserianum, though slightly more upright in growth and much hardier and better sujted for cold

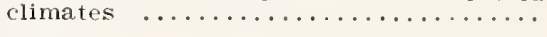

Moserianum. A inost desirable border plant, of free and graceful habit, producing long, slender, much branched stems, leafy to the base and all drooping towards the ends, apparently from the weight of the flowers and buds, al though the flower's face so none of their beauty is lost. It is marvelously freefloweling, of large size, measuring from 2 to $21 / 2$ inches in diameter. in color lich golden rellow rendered still more effective by the numerous mens and crimson anthers, and blooms

continuously the entire season. 2 feet.. $3.90 \quad 20.00 \quad 180.00$

\section{IBERIS (Hardy Candytuft).}

Most desirable dwarf plants, 8 to 10 inches, with evergreen foliage, which is completely hidden with dense heads of flowers early in the Spring.

Iittle Gem. Dwarf, pure white flowers Doz. 100 1000 in June. Glaucous bIue foliage. Splen-

did rock or edging plant; perfectly hardy.

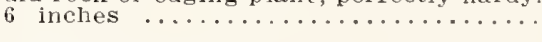

Sempervirens. Very dwaif and covered with a sheet of white, a particularly fine rock plarit. 1-year-old plants
2-year-old clumps

$\begin{array}{lll}1.50 & 10.00 \quad 90.00\end{array}$ $2.00 \quad 15.00 \quad 125.00$

\section{INULA (Fleabane).}

Golden Beauty. Free-flowering border plants with yellow flowers ............ $1.50 \quad 10.00$

INCARVILLEA (Hardy Gloxinia).

Large, rich rose, Begonia-like flowers with deep yellow throats, produced all through the Summer. A hardy perennial which succeeds well in borders and is equally valuable for greenhouse decoration. Height 18 inches.

Delavayi. Pose-pink flowers produced in Doz. 100
large trusses ...................\$2.00 $\$ 15.00 \quad \$ 125.00$

\section{IRISES (Species).}

Some very interesting sorts are here listed and described many of them splendid for naturalizing and large, permanent plantings.

Doz. $100 \quad 1000$

Cristata (Evansia). A dainty native creeping species, only 3 inches in height;

flowers rich amethyst-blue; a gem for

the rock garden. May $\ldots \ldots \ldots \ldots \ldots \ldots . \$ 2.00 \quad \$ 15.00 \quad \$ 125.00$

Tectorum (Evansia). (Syn., Tomiolopha). A rare and beautiful species from China and Japan, with delicately crested flowand Japan, with delicately clested thowthe "Roof Iris" of Japan. vivere it is the "Roof Iris" of Japan. whe of the grown on the thatched roofs of the
cottages. This Iris has proved hardy cottages. This Iris has proved hardy with us, but as the foliage is evergreen, it is benefited and will bloom more proering of straw. 1 foot. June. (SoId out for this season).

\section{IRIS PUMIIA}

These beautiful little Irises do not grow over 4 inches high, and bloom in April and May. They are fine for bordering flower beds or planting in front of the tall Irises.

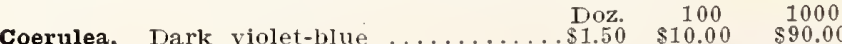

Fscelsa. A splendid pale lemon-yellow . $2.00 \quad 15.00 \quad 140.00$

Schneecuppe. A large, showy, pure white. $\begin{array}{llll}1.50 & 10.00 & 90.00\end{array}$ 


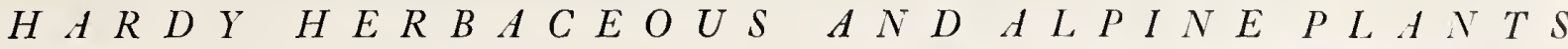

IRIS KAEMPFERI (Japanese Iris).

The magnificent Iris Kaempferi belong to the Apogons, and a field of them in bloom is a most gorgeous sight. Seeing them for the first time, one cannot withhold an exclamation of surprise, and having once seen can never forget their striking beauty.

Time to rlant. Latter part of August to the beginning of October is the best time. Late plantings should be protected by a light covering of straw or leaves after the ground is permanently frozen, to prevent roots from being heaved out of ground by frost. In northern sections late planting had best be deferred until Spring, during April and May.

Azure. Double. Immense flower, exquisite- Doz. $\quad \begin{array}{lll}100 & 1000\end{array}$ ly waved; mauve-blue with darker halo surrounding the yellow blotch at base

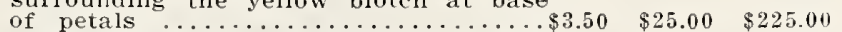

Dominator. Single. Rich indigo-blue with

$\begin{array}{lllll}\text { narrow white stripes and light center. } & & & \\ \text { One of the finest and richest colors } \ldots . .0 & 3.00 & 20.00 & 190.00\end{array}$

Gold Bound. A fine double, pure white, enriched by a creamy glow from the
gold banded center ................... 3.00

Hercule. Double, clear lilac, blue ..... 3.00

Indo. Single. Broad, wavy petals of great size, color dark rich blue, only slightly veined. The yellow central blotch is

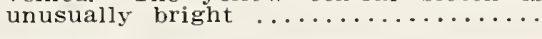

Iphigenie. Double, beautiful coloring,

deep Chinese lilac ......................... and upper petals are nearly equal in size. Bright, clear purple, with distinct rays and halo of white surrounding the golden throat, the pure white stand-

ards tipped purple .................. Six large, roval purple

kotals, with a vellow center, radiating

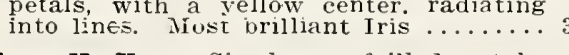

Kumo-No-Uje. Six large, frilled petals. Deep indigo-blue, shaded purple. Late bloomer ..................... fine, white, freely

Mahogany. Large double flowers, the lat-

est to bloom. Purpled mahogany-red.

The erect petals prettily crested .......

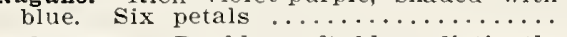

Melpomene. Double, soft blue, distinctly veined with dark blue ................. 3.00

Minerva. Single, white tinted rose .... 3.50

Momoji-No-Taki (Maple Waterfall). A choice double variegated variety; bright crimson purple, beautifully feathered in white. Petaloid-stigmas white, purple

Mount Hood. Double. Light blue shaded

atrocle. Single, superb dark reddish

violet $\ldots \ldots \ldots \ldots \ldots \ldots \ldots \ldots \ldots \ldots \ldots \ldots \ldots \ldots$.

Prosempine. Single bright rich blue produced by sanding of velvety blue on
white $\ldots \ldots \ldots \ldots \ldots \ldots \ldots \ldots \ldots \ldots \ldots$.

Pyramid. Double. Violet-purple veined white in center of each petal ....... 3.00

Tora-Odori (Dancing Tiger). Vinous purple, speckled and splashed gray. Six

Mixed Colors. Both single and double varieties. Splendid mixture ........... 2.00

20.00

20.00

190.00 .00 $.00 \quad 20.00$ 190.00 3.00 20.00 190.00 $200 \quad 200$ 190.00 3.00 20.00 190.00 25.00 225.00 .50

20.00

20.00

190.00

20.00

(2)

20.00

20.00

190.00

20.00

190.00

15.00

125.00

IRIS SIBIRICA (Siberian Iris).

Vigorous, free-flomering varieties of the easiest culture; fin for the

snow Queen. An exquisite new, hardy Doz. $100 \quad 1000$ Iris; the flowers are of a snowy whiteness, large and well formed, produced in great abundance; foliage light and graceful. A gem for flower border ol

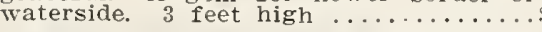

superba. Large, violet-blue flowers; handsome foliage. Fine border plant and a grand subject for planting near water, where it blooms profusely .......... 1.25

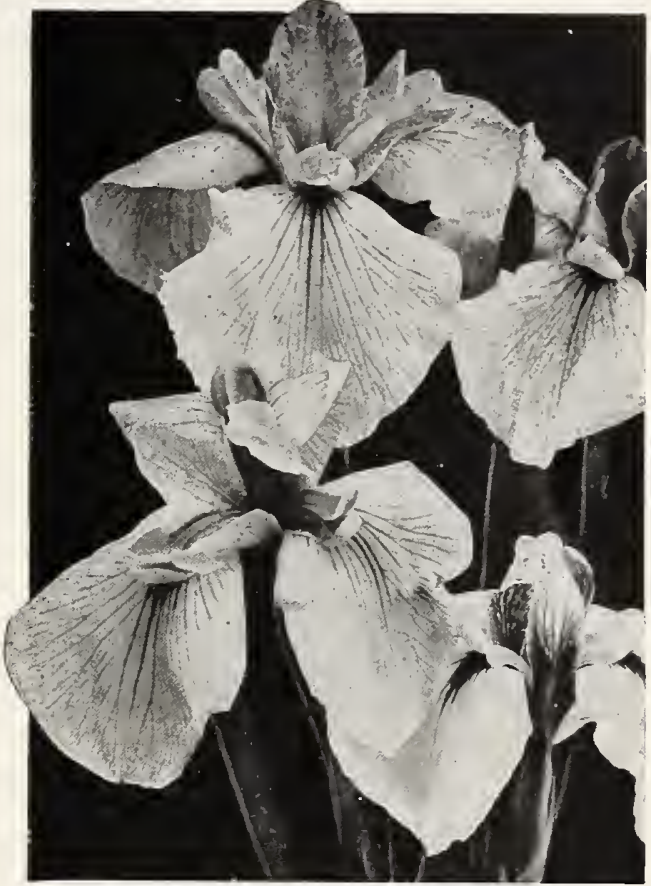

Iris Kaempferi-Japanese Iris.

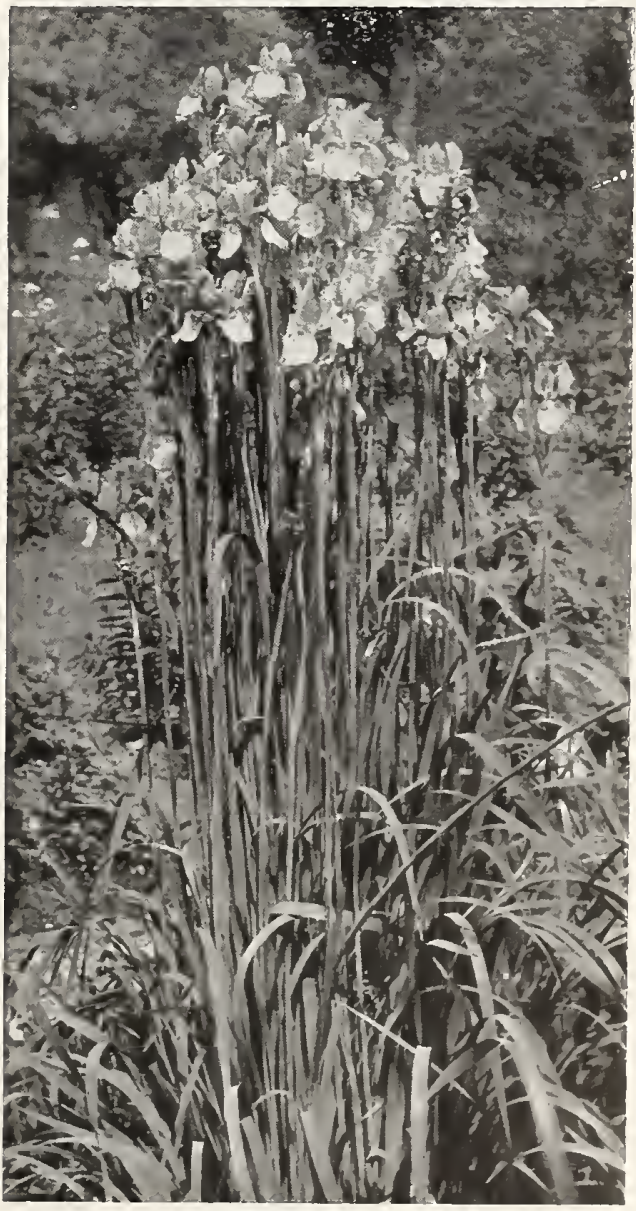

Iris Sibirica-Siberian Iris. 


$\begin{array}{lllllllllllllllllllllllllllll}T H & E & W & A & Y & S & I & D & E & G & A & R & D & E & N & S & C & O\end{array}$

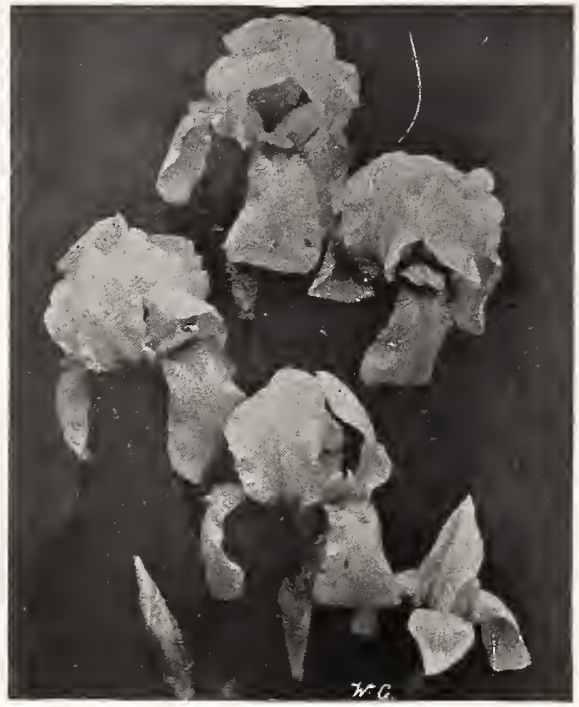

German Iris, Lord of June.

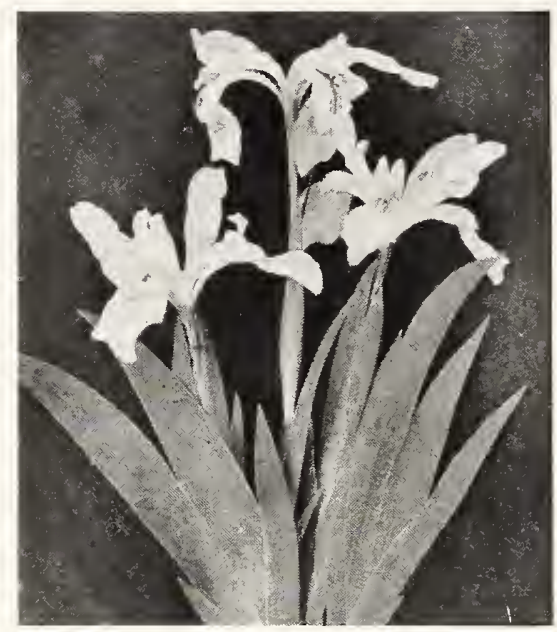

Iris Tectorum.

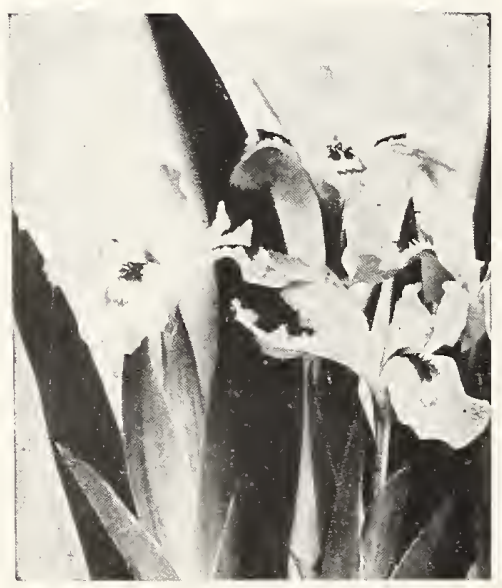

Iris Cristata.

\section{Iris Germanica (German or Flag Iris)}

The Iris is one of the finest, if not the finest, of our hardy plants. Not particular as to soil or location, but asking only that the sun shine on it. It throws up spikes of bloom that are marvelous in their delicacy of structure and the colorings which are exquisitely dainty are wonderful in their blendings and variety.

They are very effective planted in groups and if used for borders are particularly desirable in that the foliage remains fresh and upright after the blossom stalks are removed.

Plant in late August or early September preferably. Spring will do also.

The roots offered in this list are from plants transplanted a year ago and are of a size large enough to bloom next spring. The collection is up to date and consists of the best and newest standard varieties.

Twenty-five roots at 100 rate, 250 roots of a kind at 1000 rate. We guarantee the usual Wayside Gardens quality. The letter " $s$ " refers to the standards or upright petals; " $F$ " the falls or drooping petals.

\section{CHOICE NEW INTRODUCTIONS}

Ambassadeur (Vilm. 1920). S. a fascinating smoky velvety purple color; $F$. velvety purple-maroon; beards and style your regal Hower of great substance. 48 inches ..... Each, $\$ 1.75$

Ballerine (Vilm. 1920). Pall. S. light blue-violet, broad and waved at the margin; F. a deeper shade; sweetly scented. shade, sweetly scented. A splendid, tall, strong-

Cecil Minturn (New). Soft Cattleya rose A beautiful flower with broad petals, gracefully waved and crinkled; one of the finest Irises for size and extreme beauty ................................ $\$ 0.75$

Lent. A. Williamson. Rated in 1922 by the American Iris Society as the finest Iris in the world. $\mathrm{S}$. Campanula blue-violet; $\mathrm{F}$. rich royal purple with yellow beard. Very tall and distinct ..... Each, \$0.75

Icrd of June. S. lavender-blue; F. rich violet-purple. A magnificent variety of gigantic size .... Each, $\$ 0.75$

Mme. Chobaut (Denis, 1916). 36 inches. A cloverscented Plicata type. Prussian-red with light brownish veins, on a pale chalcedony ground. One of the most beautiful of all Iris ............ Each, $\$ 0.75$

Mother of Pearl. Mr. E. B. Williamson, originator of Lent. A. Williamson, America's highest rated Iris, says, "Mother of Pearl, standards and falls pale bluish lavender with a faint creamy undertone. Large flowers of exceptional substance and perfect form on well branched stems. Vigorous in growth and producing its wonderful flowers freely. I consider this an almost perfect Iris."

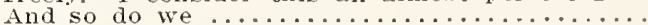

Queen Caterina (Sturt). A midseason variety of a beautiful clear orchid-purple veined with brilliant gold; the whole being further enhanced with liant gold, the whole

Shekinah (Sturt). A delightful shade of pale yellow shading to amber in the throat, with a lemon colored beard. This is a true yellow Pallida, and the first of the type. A most uncommon and very hanasome rariety ......... Each, \$0.75

Souvenir de Mme. Gaudichau (Millet 1914). A rich. deen velvety purple Iris; of fine shape and finish. Tall, early, and vely distinct. One of the most striking and remarkable of all. 42 inches .... Each, $\$ 2.00$

The do not offer new Irises until they can be sold at reasonable prices and come up to a standard set by us, which calls for a worth while improvement and not simply an addition. 


\section{$\begin{array}{llllllllllllllllllllllllllllll}H & A & R & D & Y & H & E & R & B & A & C & E & O & U & S & A & N & D & A & L & P & I & N & E & P & L & A & N & T & S\end{array}$}

\section{GENERAL LIST OF GERMAN IRIS}

Varieties marked with (*) have distinctive points of real merit, and are in our opiniou the best of the moderate priced varieties. and inferior kinds have been removed from this

All inferior kinds have been removed from this list. 100

Alcazar (Vilmorin, 1910). Certificate,

N. H. F., 1909; F. C. C. F. H. S., 1916.

S. light bluish violet; $F$. deep purple

with bronze-veined throat. Striking
flower $\ldots \ldots \ldots \ldots \ldots \ldots \ldots \ldots \ldots \ldots \ldots \ldots \ldots \ldots$

*Archeveque (Vilmorin, 1911). Certificate R. H. S., 1916. S. deep purple-violet; F. deep velvely violet. 24 inches ........ $1.75 \quad 12.00 \quad 100.00$

Brooksiana. Charming flowers of neat form, self-colored delicate rose-lilac, without veining: Beautiful in masses.. $1.00 \quad 5.00$

Candelabre 1.25

40.00

*Caterina (Foster, 1909). A. M., R. H. S., 1916. Lavender-blue and lilac of same coloring as Pallida Dalmatica, but taller, with more graceful stem. A beautiful flower, but a poor grower in cold sections. $4 \mathrm{~s}$ inches .................... $1.75 \quad 12.00$ 115.00

Caprice (Vilmorin, 1904). Certificate, N. ; F. deeper rosy red. Large and handsome. 24 inches.

*Cherubin. This may be described as a pale edition of Her Majesty. The standards are very pale lilac, the falls are pale lilac thinly veined with purple ... 1.50

Fairy (Kennicott, 1905). White, delicately bordered and suffused pale blue. The tallest standard variety giving a white effect. Not new but not known or appreciated as it should be. 40 inches . 1.00

Helge. Lemon-yellow with pearl shading.

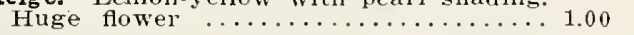

*Isoline. Round standards of pale pinkish buff, strongly flushed mauve; the sharply reflexed falls are chinese violet with russet tints at the sides; bewjldering shades but most attractive .............. 3.00

Juniata. A stately plant with gracefully carried maure to manganese violet blos-

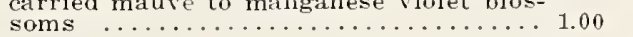

*Jeanne d'Arc (Verdier, 1907). S. very large and ruffied, somewhat spreading, white, delicately penciled lilac; $F$. white edged lilac at base. The standards heing somewhat loosely held, flutter in the breeze in a truly delightful manner ... 1.50

* King of Iris (Goos \& Koenemann, 1907) A. M., R. H. S., 1916. S. clear lemonfellow; F. rich maroon, bordered yellow. yrilliant colors. Jarge flowers. Very Brilliant colors. Large flowers. Very

Ioreley. Light yellow, blue falls bordered cream ........................

*Leonidas. Standards clear mauve; falls rosy mauve. Big, of fine form, hand-

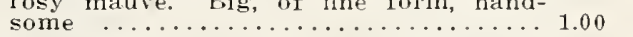

*Ioute (Vilmorin, 1904). S. light mauve with bronze sheen; $F$. soft red-violet, very large flower $\ldots \ldots \ldots \ldots \ldots \ldots \ldots$.

Madame Chereau. White, elegantly frilled with a wide border of clear blue ...... 1.00

Mandraliscae. Rich lavender-purple, tall, large and handsome; very early ...... 1.00

Monsignor. It possesses a distinctive and pleasing shape, rich coloring and a dark outline to the segments for emphasis. Standards violet; falls heavily veined purple, leaving a border of the violet;

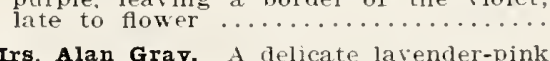

Mrs. Alan Gray. A delicate lavender-pink variety of rather early bloom ........... $1.00 \quad 5.00$

midnight. A rich deep purple, the finest in this color; a fine cut flower ......... $1.50 \quad 10.00$

zribelungen (Goos \& Koenemann, 1910). S. fawn and yellow; F. violet-purple on bronze. Very large flowers; strong, vigorous grower ...................... 1.50

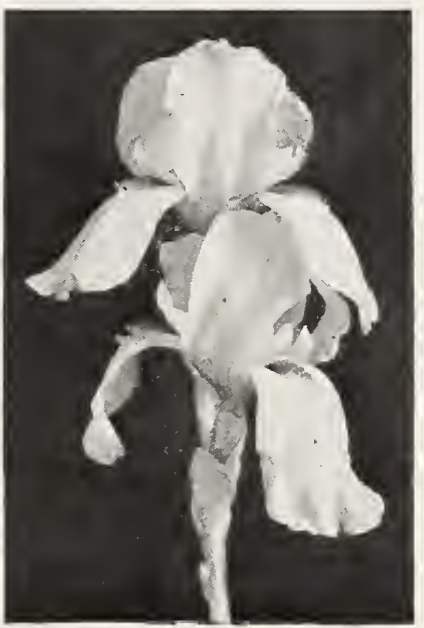

Iris, Helge.

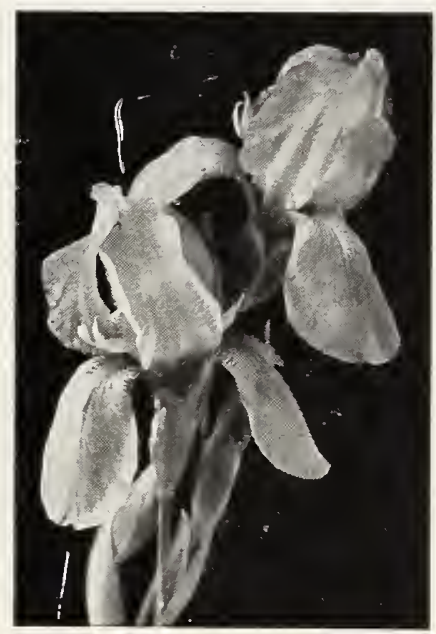

Iris, Monsignor.

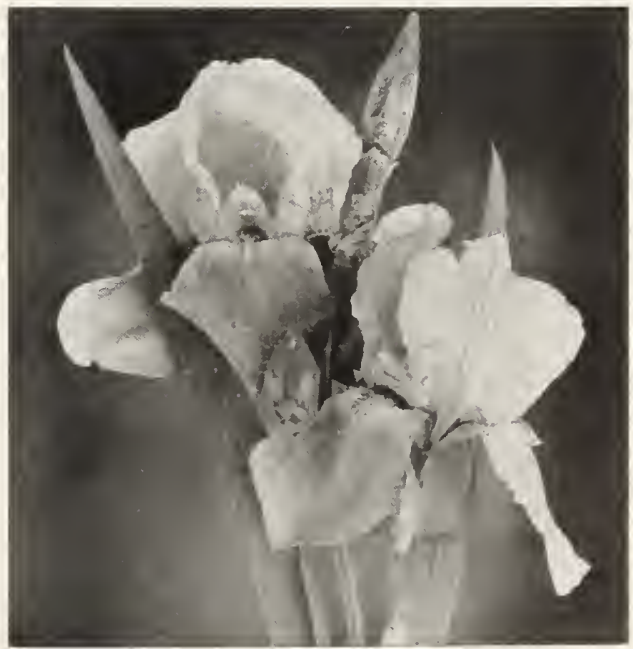

Iris, Oriflamme. 


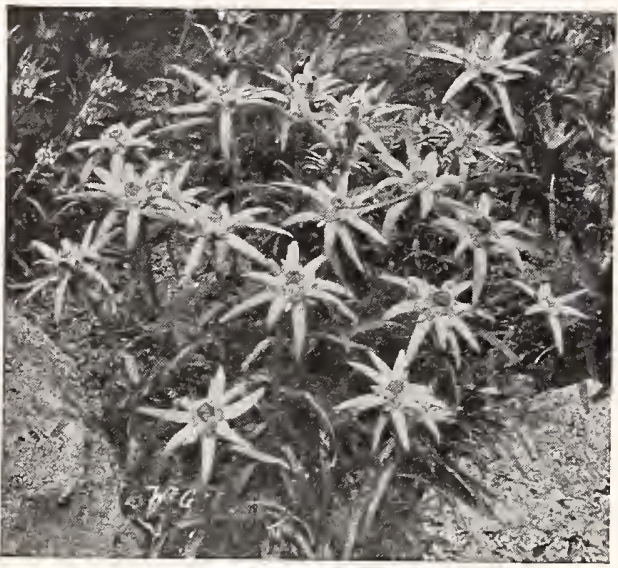

Leontopodium-Edelweiss.

No rock garden is complete without this plant

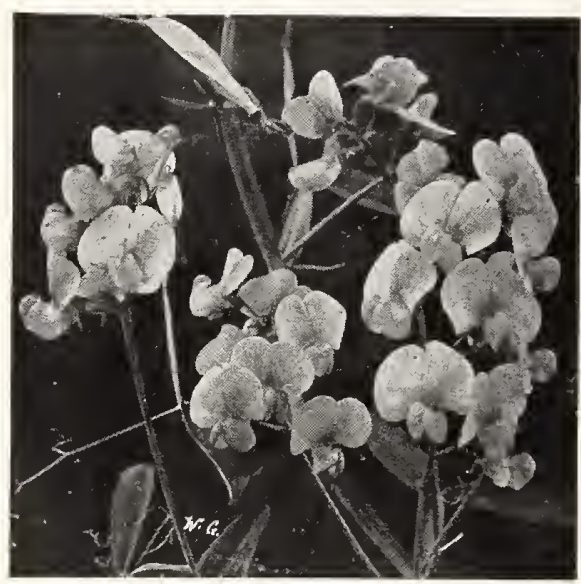

Lathy rus Latifolius.

A splendid, rapid growing vine.

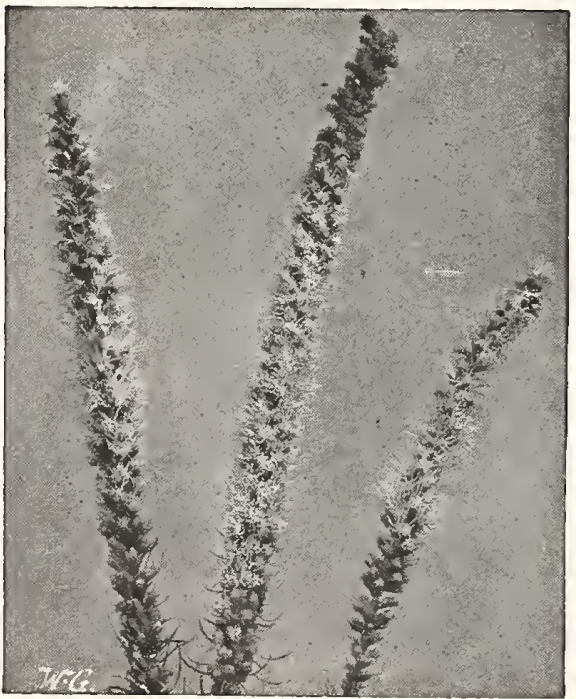

Liatris-Blazing Siar.
IRIS GERMANICA-Continued.

* Nuee d'orage (Verdier, 1905). (Syn Doz. $100 \quad 1000$ Storm Cloud). Cert., N. H. F., 1905. S slaty gray; F. bronze and purple. Large

flowers. 24 inches .............\$1.15 $\$ 7.00 \quad \$ 60.00$

* Oriflamme (Vilmorin, 1904). Cert., N. H. F., 1905; A. M., R. H. S., 1916. S. light biue: Fich violet-purple. Immense handsome flowers of Ames form. 30

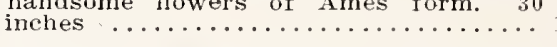

* Pallida Dalmatica (True). A. M., R. H. S., 1916. S. lavender; $F$. clear, deep lavender. A variety of this name is mentioned in Gerrarde's Herbal in 1597 , and it has been grown in this country more than one hundred years and is often seen in old gardens, but the true variety is still scarce. Unsulpassed in its class 40 inches

Parisiana (Vilmorin, 1911). S. white ground, dotted and shaded lilac-purple F. white, frilled at the edge with lilac.

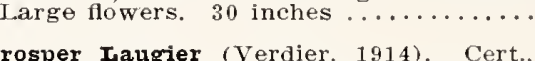

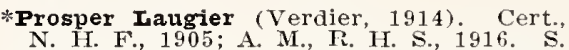
light bronze-red; $F$. velvety ruby-purple with whitc beard yellow tipped. Very handsome. Vigorous growth. 36 inches. $1.25 \quad 8.00$

Perfection (Barr, about 1880). H. C., P. H. S., 1916 . S. light blue; $\dot{F}$. dark, velviety violet-black with orange beard. Handsome flower that attracts much attention in mass. 38 inches ........... 1.00

rincess victoria Toulse (Goos \& Koene

mann, 1910) S. sulphur-yellow: F rich plum, bordered cream. 30 inches ..... $1.10 \quad 6.00 \quad 50.00$

Rhein Nize (Goos \& Koenemann, 1910). A. M., R. H. S., 1916 . S. white; F. violet-blue with white edge. Tall and large. very fine. Strong grower. 30 inches. 1.10

Storm cloud. (See Nuee d'Orage).

\section{LATHYRUS (Everlasting Sweet Pea).}

Iatifolius. These Everlasting Peas are but little known in this country, but are great favorites in England. They are extrellises, arbors, etc.

Pink Beauty. Large racemes of pleasing deep rose flowers ….............\$1.75 $\$ 12.50 \quad \$ 100.00$ Red. The well known red Everlasting Pea. $1.50 \quad 10.00 \quad 90.00$ White Pearl. A great improvement on the older white variety, the stems giving from 12 to 15 flowers each ............ $1.50 \quad 10.00$

LAVANDULA (Lavender).

Nana. Is a very fine new dwarf English introduction. Good for edging and planting between roses .................... $2.50 \quad 18.00 \quad 170.00$

vera. This is the true Sweet Lavender; grows about 18 inches high; delightfully fragrant blue flowers in July and August ..........................

LEONTOPODIUM (Edelweiss).

Alpinum. A well known Alpine with pretty white leaves alid small yellow flowers which are surrounded by starlike heads of leaves, clothed with a dense whitc, woolly substance. A splendid plant for the rock garden. 4 to 5 inches. June to August. Supplied in pots only $\ldots \ldots \ldots \ldots \ldots \ldots \ldots \ldots \ldots \ldots$

LIATRIS (Blazing Star or Gay Feather).

Montana. Similar to Pycnostachya, but $\begin{array}{llll}\text { very dwalf and suitable for rock garden. } 2.00 & 15.00 & 130.00\end{array}$

Fycnostachya. The popular name of this plant is Kansas Gay Feather. Nothing can be planted that will attract more attention on account of its unusual appearance; but it is beautiful as well as pearance; but it is in midsummer and throws up long, narrow spikes of rich throws up long, narrow spikes of rich purple flowers, which last a long time. Atraction for butterflies ................ 2.00 $15.00 \quad 130.00$ 
LILY-OF-THE-VALLEY (See Convallaria).

LINARIA (Toad Flax).

Cymbalaria (Kenilworth Jyy, or Mother of Doz. $100 \quad 1000$

Thousands) Thender and purpler of

charming, neat, hardy perennial trailing

plant, suitable for rock work and wall

plardens $\ldots \ldots \ldots \ldots \ldots \ldots \ldots \ldots \ldots \ldots \ldots \$ 1.75 \quad \$ 12.00 \quad \$ 100.00$

Dalmatica. Fine for borders or perennia

garden. Glaucous blue foliage and

spikes of golden yellow blossoms; min-

iature Snapdragon. Loves a sunny spot

in well drained soil .................. $1.50 \quad 10.00 \quad 90.00$

\section{LINUM (Flax).}

A desirable plant for the border or rockery, growing 2 feet high, with light, graceful foliage and large flowers all Summer.

Elavnm Foz. $100 \quad 1000$ yellow blossoms .................... $\$ 1.50 \quad \$ 10.00 \quad \$ 80.00$

Narbonnense. Forms a spreading clump

of attractive foliage with a profusion of

azure-blue flowers with white eye. Very

$\begin{array}{llll}\text { handsome for the rockery } \ldots \ldots \ldots & \ldots . . .\end{array}$

Perenne. Very attractive, both in foliage and bloom. Flowers beautiful pale blue

on slender, graceful stems ............ $1.50 \quad 10.00 \quad 80.00$

Perenne. White ................. $1.50 \quad 10.00 \quad 80.00$

\section{LITHOSPERMUM (Gromwell).}

Furpureum. A woody plant, in appearance much like lavendula vera. Heads of beautiful pale blue and purple flowers. Should hare a choice place in the rock garden in full sun and rich soil $\ldots \ldots \ldots 7.00 \quad 50.00$

LOBELIA (Indian Paintbrush).

Handsome border plants, thriving in any ordinary garden soil, but preferring a moist, deep loam. Season August till late September.

Cardinalis (Cardinal Flower) Rich, Doz. $100 \quad 1000$ cardinal flowers. Strong plants, hery producing ten to eighteen spikes. 24

producing ten to eighteen spikes. 24
to 30 inches long ................... $\$ 1.75 \quad \$ 12.00 \quad \$ 100.00$ sgphilitica (Great Blue Lobelia). Similar in growth to the last, but the flowers are blue, streaked with white. Plant in a moist place. Desirable for border of brook or lake $\ldots \cdots \cdots \cdots \cdots$

90.00

LONICERA (Honeysuckle, see page 53).

\section{LYCHNIS (Campion).}

A fine old-fashioned flower, bearing large heads of brilliantly colored flowers, that liven up the border during summer and early Autumn.

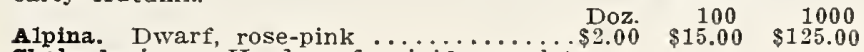
Chalcedonica. Heads of vivid scarlet flowers, blooming a long time. One of

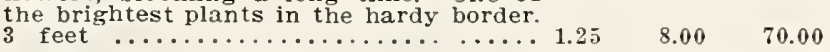

Haageana. 1 foot. June to August. Very

showy; producing orange-red, scarlet or

crimson flowers nearly 2 inches across $\quad 1.50 \quad 10.00$

iscaria flore pleno. A fine double varie-

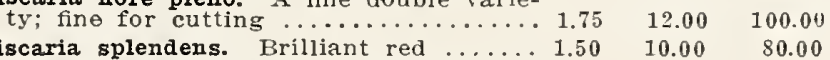

Viscaria splendens alba. Flowering pro-

fusely in June and July; it is one of the

fusely in June and July; it is one of the

year. 8 to 10 inches high; fine border

plant ........................... $1.50 \quad 10.00 \quad 80.00$

LYSIMACHIA (Loosestrife).

Clethroides. Long, recurved spikes of pure white flowers, from July to Sep-

$\begin{array}{llll}\text { tember. A desirable variety, } 2 \text { feet } & 2.00 & 15.00 & 145.00\end{array}$

Fortunel. A neat variety, growing about 18 inches high, with dense, upright spikes of white flowers in August .... $1.75 \quad 12.00 \quad 100.00$

Nummularia (Creeping Jenny or Money-

wort). Valuable for planting under

trees or shrubs where grass will not

trees or shrubs where grass will not

$1.35-9.00$

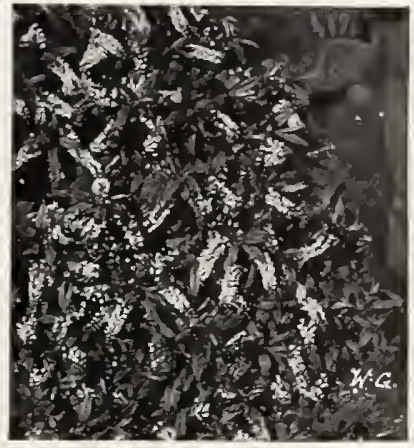

Lysimachia Clethroides.

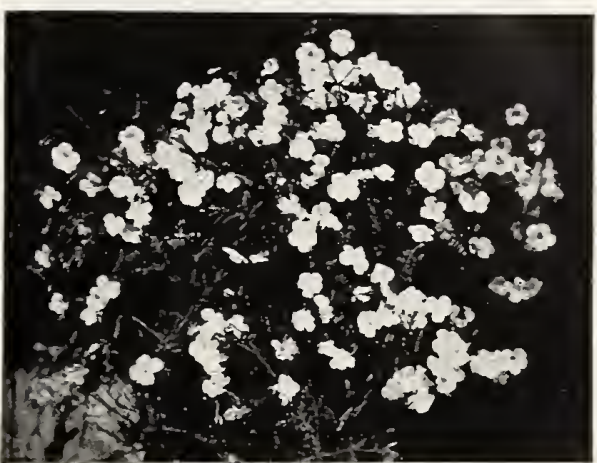

Linum Narbonnense.

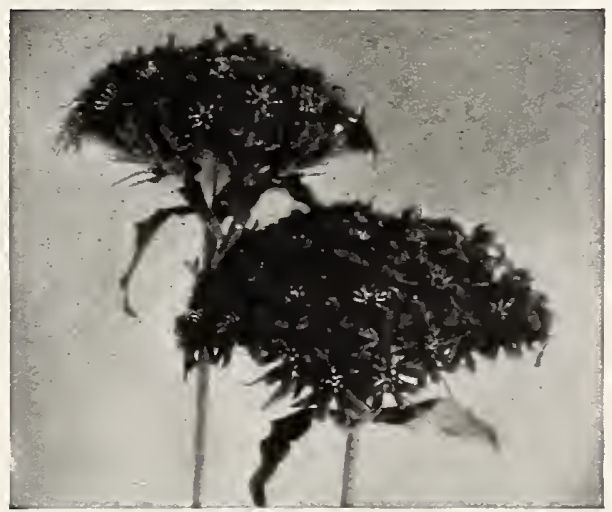

Lychnis Chalcedonica.

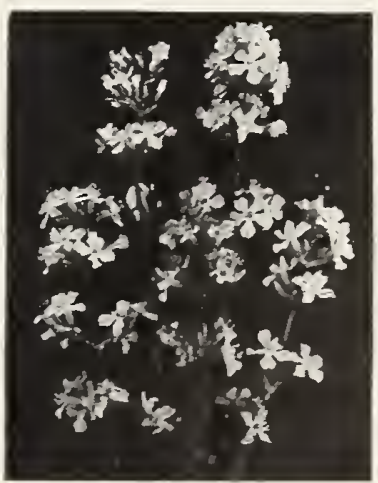

Lychnis Viscaria. 


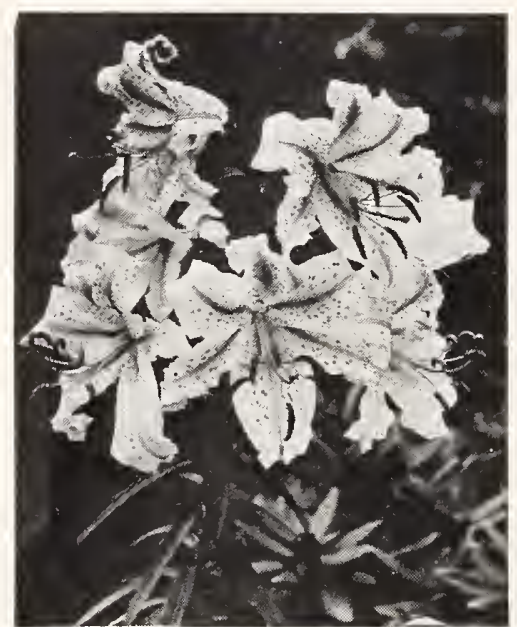

Lilium Auratum.

Likes a cool, moist spot in the garden.

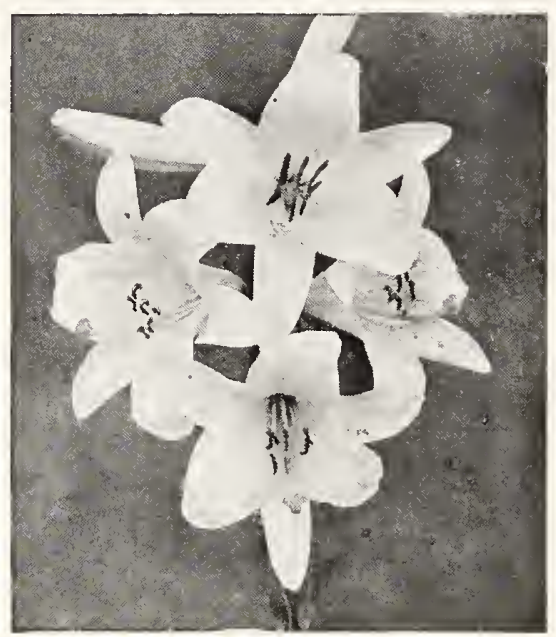

Lilium Candidum.

Plant with Delphiniums for a fine effect.

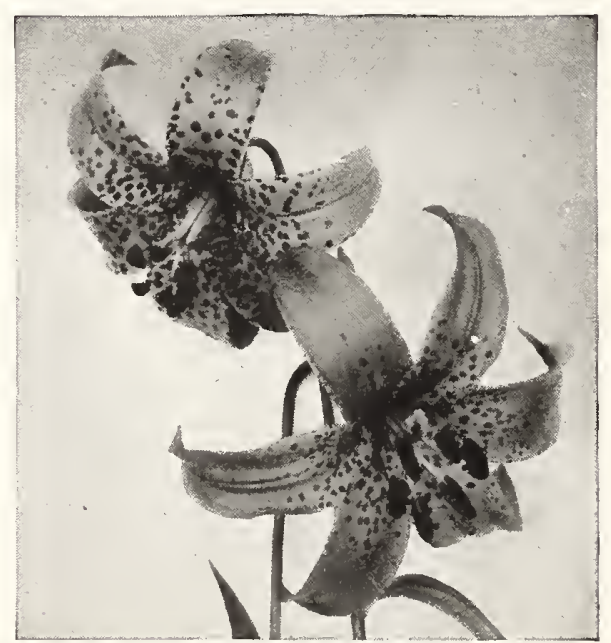

Lilium Canadensis.

\section{Lilies \\ Hardy Garden Varieties}

Noble and beautiful flowers which are too frequently strangers in American gardens. It is always with a touch of sadness that we note the infrequency of Lilies in American gardens. No flower, it seems to us, is at once so noble and so beautiful. Nor is there lack of variety. Furthermore, the Lily is the garden when in bloom.

There is a notion that Lilies are "hard to grow." Some of the rarer species are, it is true; they not only stubbornly refuse to make themselves at home in the garden, unless conditions are precisely to their liking, but some of them cannot endure the nolthern Winter without the necessary covering of litter, which many other tender plants require. Lnless one goes in for Lilies to the extent of making a hobby of them however these can all be left to the collector and there will be quite enough species lemaining to give one a Lily season in the three months durremaining to give one a Lily season in the three months duronly relatively brief length. Wve say species for the reason only lelatively brief length. We say species for the reason that the Lilies in cultivation show an exceptionally low per-
centage of horticultural varieties. Possibly because Nature made every species perfect to begin with, the hand of the hybridizer has been loath to endeavor to "paint the Lily," as it were.

The valieties which we offer in these three pages are such as have, with us, withstood the Summer's drought and the severest of Winters, and have thus proven themselves worthy of a place in your garden.

DELIVERY-This depends upon the arrival of the bulbs from our foreign sources. Many get here too late for Autumn plantThose marked $(* *)$ should be planted in the Fall only; those marked (*) may be planted in Spring or Fall, preferably the latter; all the others are for spring delivery.

Auratum (Golden-Banded Japan Lily) Three Doz. 100

Tndoubtedly one of the finest. Its large graceful, fragrant flowers are composed of sis petals of a delicate ivory-white of sis petals of a delicate ivory-white color, thickly studded with chocolatecenter a golden yellow; 3 to 5 feet. July to September.

Iarge bulbs

Mammoth bulbs

Auratum platyphyllum. Also called "Macranthum." This is a robust growing form; the stem is stouter and attains a greater height; the leaves are much broader: enormous flowers, white, much broader: enormous fowers, white,
richly spotted yellow. Lndoubtedly richly spotted yellow. Tindoubtedly
the choicest of all.

Iarge bulbs

Mammoth bulbs

Auratum rubro vittatum. Similar to the above but the flowers are dark rose-pink. $3.00 \quad 10.00 \quad 75.00$

Auratum pictum. Is another splendid form of Auratum and fortunately a

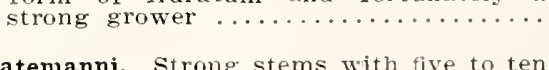

Batemanni. Strong stems with five to ten flowers of a reddish orange color. July-

August 3 to $t$ feet

Browni odorum. A vigorous grower with large, trumpet-shaped flowers of clear white, veined outside with purplish maroon $\ldots \ldots \ldots \ldots \ldots \ldots \ldots \ldots \ldots \ldots \ldots \ldots \ldots \ldots \ldots \ldots$. Lily. Graceful and charming flowers.

Lily. Gracerul and charming fowers.

* Candidum Madonna or Annunciation Lily). This is the old-rashioned garden Lily, and one of the most beautiful. Ready in september only. First size.

Chalcedonicum (Scarlet Turk's Cap Lily). Small flowers in loose clusters with recurved, bright red petals. A handsome and attractive Lily. July. 3 to 4 feet. $4.00 \quad 15.00$ 
IIIIES-Continued. Colchtcam (Scovitzianum). A beautiful
lemon-yellow Lily, produced in pyra-

midal clusters of drooping, waxlike flow

ers. June. 4 to 5 feet $\ldots \ldots \ldots \ldots \ldots \ldots \ldots \$ 3.75 \quad \$ 12.00 \quad \$ 85.00$

*Dararicum. This beautiful Lily comes from the home of L. Tenuifolium in Siberia. It resembles a native Philadelphicum. It is of easy culture, grows two or three to five upright scarlet flowtwo or three to five upright scarlet flow

Igantoum (Himalayicum) 5 to 7 feet

Gigaztoum (Himalayicum). 5 to 7 feet. the Lilies. White, fragrant, funnelshaped flowers .........\$4.00 each; 12.00

(Rare)

Eanmon1. Most desirable; not particular in its cultural requirements and extremely handsome in flower; does well in light loam. Plant among shrubs and low plants to protect young shoots, this being one of the earliest Lilies to appear in the Spring. The stem reaches a height of 4 to 5 feet, carrying blossoms height of 4 to 5 feet, carrying blossoms petals being of a bright orange spotted petals being of a bright orange spotted more or less with brown, of a waxy
texture. Admirable for pot culture. June flowering ................ 1.10

* Fenryl. A new Japanese Lily that has made a sensation in Europe. It has the same form and appearance as the Speciosum varieties, but the flowers are bright orange-yellow. We grow this variety now ourselves from seed. They are as hardy as a tree Shipment October ist hardy as a tree........................

ramery Unique for its color and grows xramerl. Unique for its color and grows shaped, finely formed flowers are 6 inches or more in length and as much across, of a beautiful clear pink color, often shaded blush ...................1

*Martagon (Dalmaticum, Turk's Cap Lily") A handsome Lily, bearing clusters of purple, waxlike floners. Thrives best in partial shade June 5 feet ........"

Pardalinum (Leopard Lily) Flowers te flexed, bright yellow at base, spotted brownish purple, remainder orangesearlet. 3 to 4 feet. July and August.

Philadelphicum. A handsome native Lily with yellow, cup-shaped flowers, spotted maroon and shaded orange at ends of petals. Good for naturalizing. July.

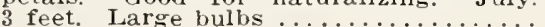

Pomponicum. A brilliant red Turk's Cap Lily. Much like Chalcedonicum, but with the heads of flowers rather more loosely

Pyrenaicum (Yellow Turk's Cap Lily). A lily of easy cultivation, with many small, yellow flowers, dotted brown. Reflexed petals. June. 3 feet .......... 1.8

*Regale or myriophyllum (The Regal Lily) It is absolutely hardy, and is excellen for forcing. It has been predicted that this will become the Easter Lily of the future, and being so hardy, may be grown at home. The flowers are white slightl suffused with pink. with a beau tiful shade of anary-rellow at the center and of canary-jellow at the center, and extending part way up the trumpet. It is delightfully perfumed. $1^{*} e-$ minding one of the Jasmine. and lacking the heary, opplessive odor of most Lilies. Blooms out-of-doors early in July.

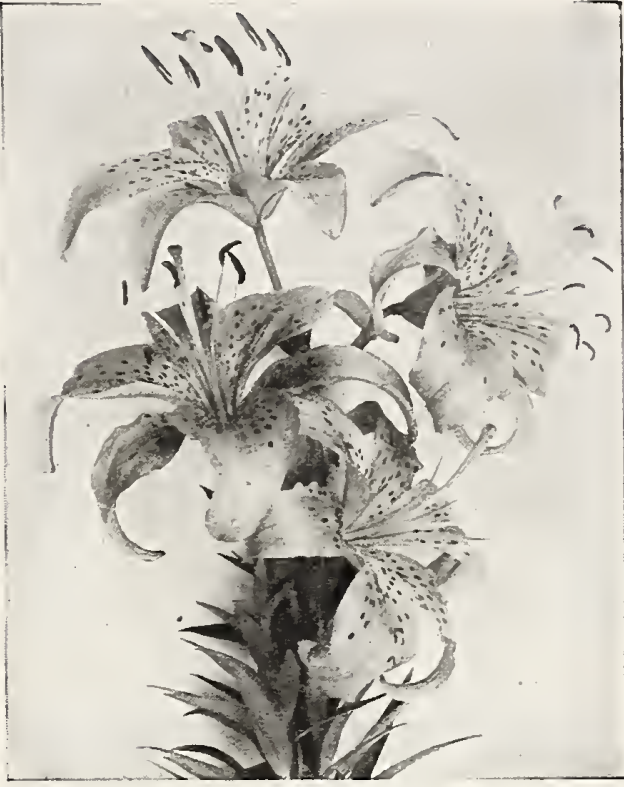

Lilium Henryi.

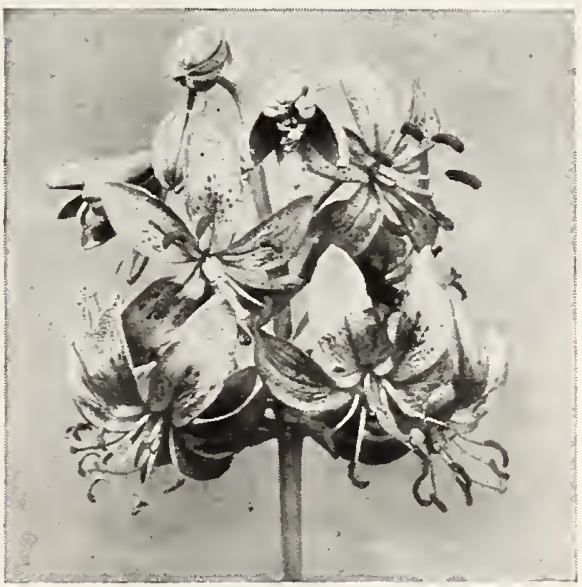

Lilium Hansoni.

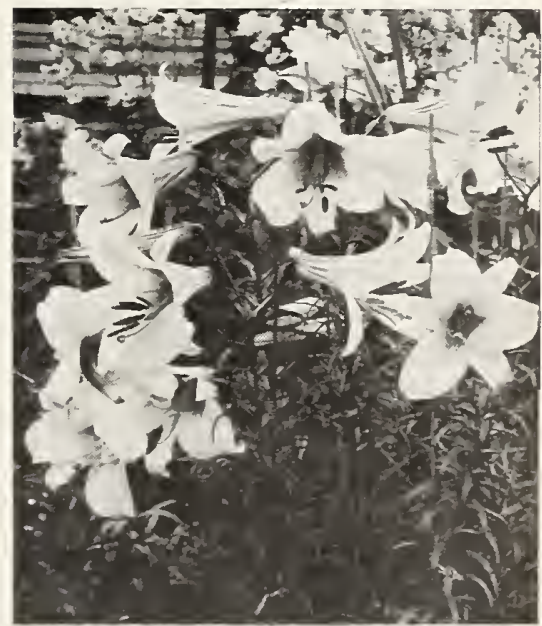

Regal Lily. 


$T H E \quad W A Y S I D E \quad G A R D E N S, \quad M E N T O R, \quad O H I O$

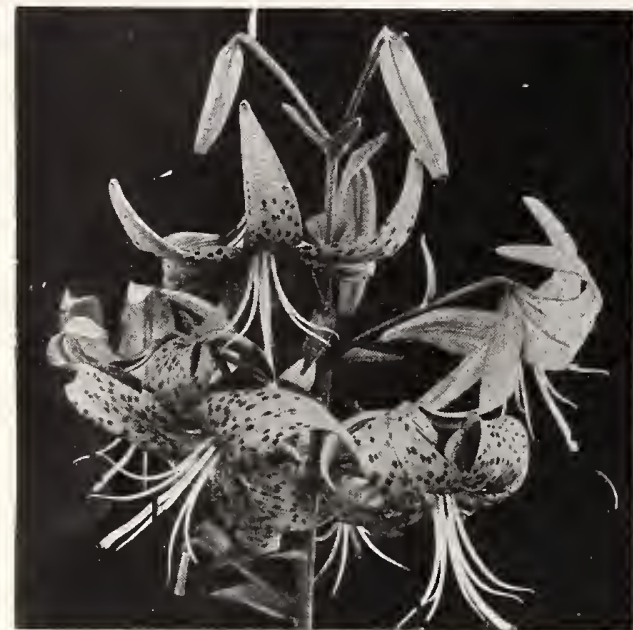

Lilium Tigrinum.

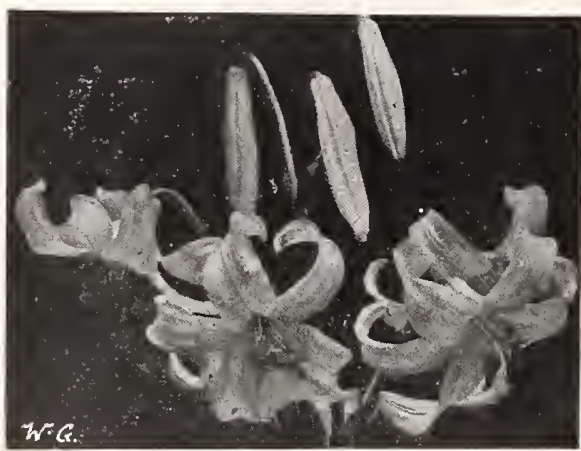

Lilium Testaceum.

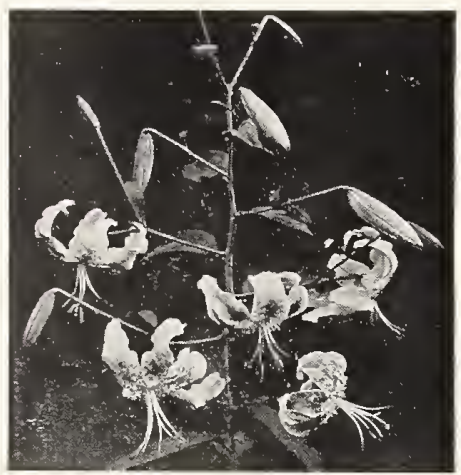

Lilium Speciosum.

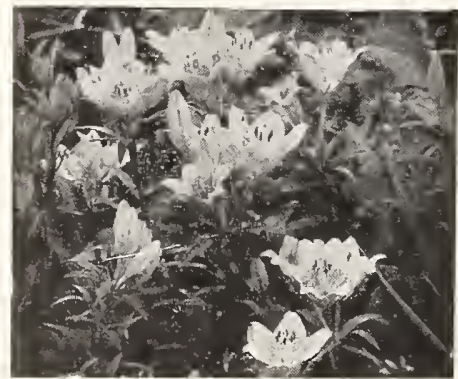

Lilium Davuricum.
IIIIES-Continued.

Rubellum. Beautiful small Lily. The
color varies from a deep rose-pink to color varies from a deep rose-pink to almost white, with yellow anthers; very
fragrant, small funnel-shaped flowers; grows $11 \%$ feet high. It does best in light soil f..................... \$1.00 \$3.50 \$25.00

Speciosum album. The Speciosum or Lancifolium are the most important of all the Japanese Lilies, always satisfactory. The variety here offered has large, white flowers of great substance, with a greenish band running through the center of each petal.

rarge bulbs ................. so 3.00

20.00

Mammoth bulbs ................... $1.75 \quad 5.50 \quad 40.00$

Speciosum magnificum. Magnificent large flowers of rich deep red.

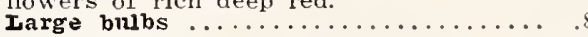

Mammoth bulbs ............... 1.10

Speciosum Melpomene. A darker shade of red ard crimson markings than the

preceding bubs $\ldots \ldots \ldots \ldots \ldots \ldots \ldots \ldots \ldots . .80$

Mammoth boubs

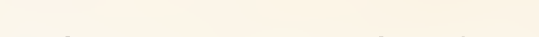

* Superbum. 3 to 4 feet. July. Flowers bright reddish orange, conspicuously spotted $\ldots \ldots \ldots \ldots \ldots \ldots \ldots \ldots \ldots$

*Testaceuin (Excelsum or Nankeen Lily). This is one of the finest of all Lilies. The color is difficult to describe, being a shading of dull apricot with orange-yellow anthers. A most graceful Lily and low anthers. A most graceful Lily and a good companion to L. candidum. June-
July. 5 feet. Extra large flowering July. 5 feet. Extra large flowering

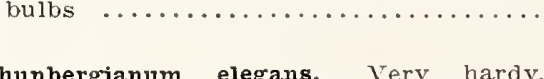

Thunbergianum elegans. Very hardy, dwarf Lilies thriving in any garden and producing large, erect flowers of various varieties grow from $1 \frac{1 / 2}{\mathrm{~J}}$ to 2 feet and hloom during June and July.

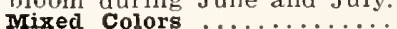

Thunbergianum elegans, Alice Wilson. A clear lemon-yellow form of the above.

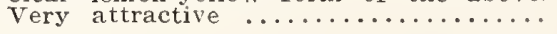

Thunbergianum elegans atrosanguineum. A very dark form of Elegans. Inside of Aide showeep, velvety cruster........

*Tigrinum flore pleno (The Double Tiger Lily). The only double Tiger Lily

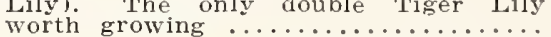

worth growing $\ldots \ldots \ldots \ldots \ldots \ldots \ldots \ldots \ldots \ldots$ known

*Tigrinum simplex (The well known
Single Tiger Lily). Of easiest culture and worthy of general planting on ac-

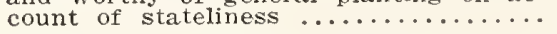

wallacei. A handsome Lily of a beautiful shade of the warmest apricot with rosy shading August $11 / 2$ to 2 feet ...

Washingtonianum. A beautiful Lily from California, with large. reflexed flowers, varying in color from light to a rich wine color, slightly spotted deeper. This variety requires a moist but well drained situation. June-July. 3 to 5 feet. Extra large bulbs $\ldots \ldots \ldots \ldots \ldots \ldots \ldots$

willinottiae. One of the finest garden Lilies, although little known. Lovely in its graceful habit, slender foliage and heads of vivid orange-red flowers and $\begin{array}{lllll}\text { stitution. July-Aigust. } 3 \text { to } 4 \text { feet. } & 1.00 & 10.00 & 75 .(1)\end{array}$ 


\section{$\begin{array}{llllllllllllllllllllllllllllll}H & A & R & D & Y & H & E & R & B & A & C & E & O & U & S\end{array}$}

\section{LUPINUS (Lupines).}

The Lupines produce beautiful long spikes of pea-shaped flowers a foot long on stems three feet high. They are perfectly. hardy but cannot endure drought, and must be planted in well prepared garden soil and kept watered in dry weather.

Wayside Gardens New Sweet-Scented HyDoz. $100 \quad 1000$ brids (Polyphyllus). A wonderful new strain that may be classed among the most beautiful of all hardy flowers. Colors are both rich and delicate in shades of blue, mauve, pink, etc., and the flowers are borne in long spikes that for size and beauty rival giant Snapfor size and beauty rival giant Snapsweet scentcd, makes these one of the best garden plants we have ever distributed ........................ $\$ 3.00$ Polyphyllus (Hardy Lupin). Clear blue.

Polyphyllus, Moerbeimi. Pink ........ 3.00

$\$ 20.00$

15.00

15.00

Polyphyllus roseus. A splendid new variety, with flowers of beautifully shaded

rose ........................... 2.00

Polyphyllus, Rosy Morn. Deep pink ...8 8.00

Polyphyllus, Ruby King. Ruby-red .... 4.00

60.00

30.00

LYTHRUM (Purple Loosestrife).

Superbum roseum. Very showy; splendid for banks of streams and ponds ...... 1.50

MALVA (Dwarf Mallow)

Moschata. $1 \frac{1}{2}$ to 2 feet. July to September. Fragrant flowers in clusters, of a

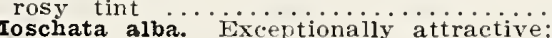

MATRICARIA (See Feverfew; Mayweed).

\section{MAZUS.}

Rugosus. A dwarf and interesting Alpine plant from the Himalayan Mountains, covered in early Spring with dainty lilac

and white flowers. 4 inches ........... 3.00

20.00

MECONOPSIS (Welsh Poppy).

Iatifolia $\ldots \ldots \ldots \ldots \ldots \ldots$........

Virginica. An early Spring-flowering plant, growing about 1 to $1 \frac{1}{2}$ feet high with drooping panicles of handsome light blue flowers fading to clear pink; one of the most interesting of our native Spring

$$
\begin{aligned}
& \text { most interesting of our native spring } \\
& \text { flowers } \ldots \ldots \ldots \ldots \ldots \ldots \ldots \ldots \ldots \ldots \ldots \ldots \ldots \\
& 1.50
\end{aligned}
$$

MONARDA OR BERGAMOT (Oswego Tea).

Showy plants growing from 2 to 3 feet high, succeeding in any soil or position, with aromatic foliage, and producing their bright flowers during July and August.

Didyma Cambricte Scarlet. Doz. $100 \quad 1000$ crimson-scarlet ................\$1.50 \$10.00 $\$ 90.00$

\section{MONTBRETIA (Tritonia).}

One of the brightest of our summer-flowering bulbs, and should be set during April or May. They should be protected during the Winter with a heavy covering of leaves or litter.

Crocosmaeflora. Pure yellow, reverse of Doz. $100 \quad 1000$ petals orange; large flowers $\ldots . . . \ldots \ldots 1.00 \quad \$ 6.00 \quad \$ 45.00$ King Edmund. A robust grower with large, open flowers, rich yellow, with a

carmine-blotched center ..............

Lord Nelson. A handsome dark-stemmed variety, flowers of great substance, of Rheingold. A beautiful clear golden yellow: large spike and very vigorous grower
peciosa. large, of intense scarlet shade ....... 1.00

\subsection{0 \\ 55.00} 1.00

MITCHELLA.

Repens (Partridge Berry). A little trailing evergreen. It forms fine mats unde evergreens, and when once established, $\ldots$ is sure to please ................ 3.00

MITELLA (Bishop's Cap).

Diphylla. A gem for a shady position. Feathery spikes of creamy white flowers. 12 to 18 inches. May and June ...... 1.5010 .00

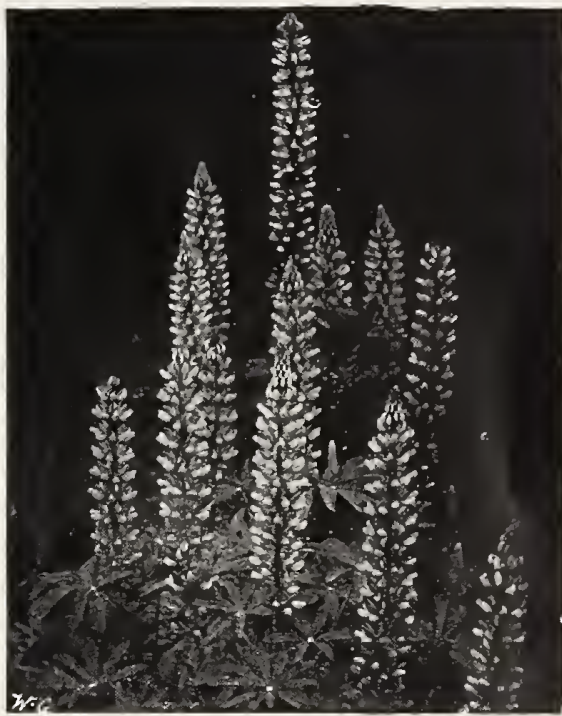

Lupinus.

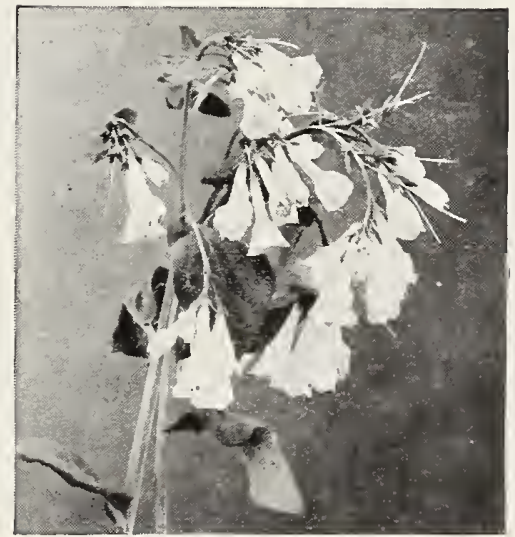

Mertensia Virginica.

Plant in shady places.

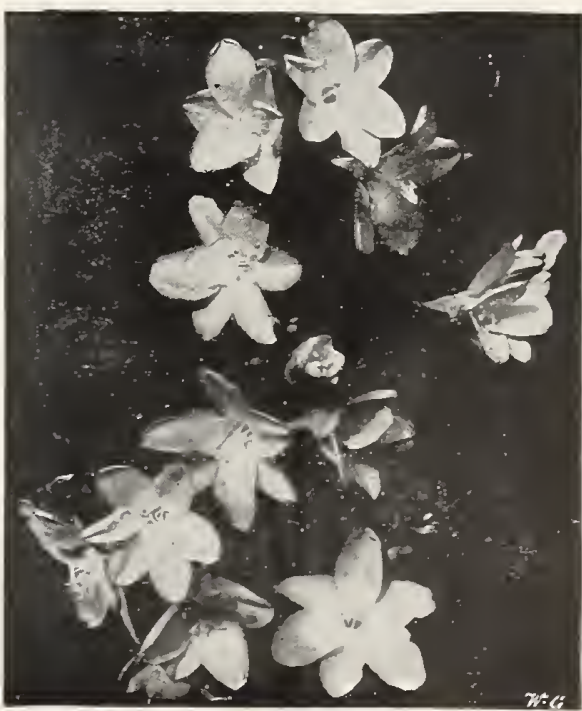

Montbretia. 


$\begin{array}{llllllllllllllllllllllll}T H E & H & H & Y & S & \end{array}$

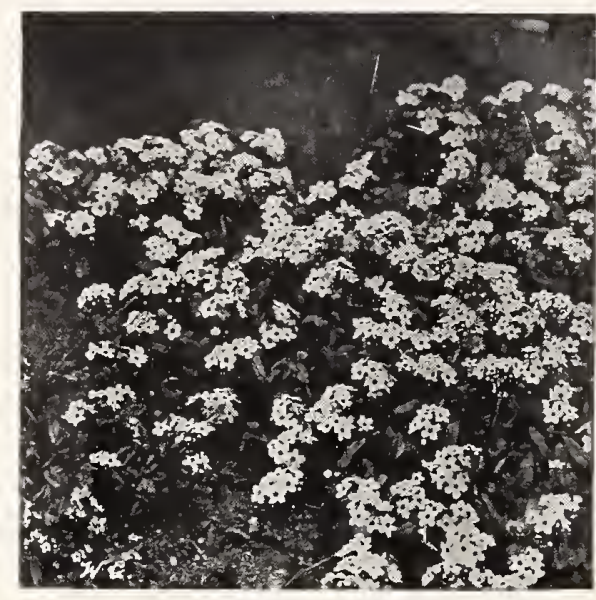

Myosotis Palustris.

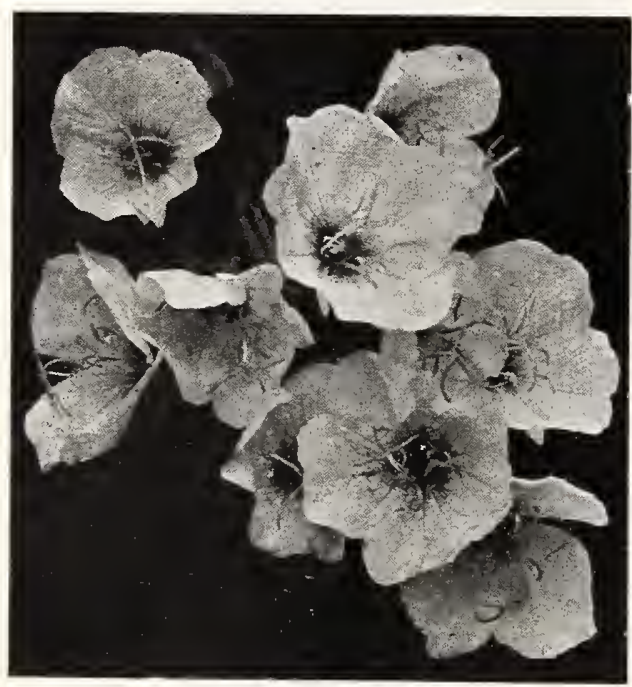

Oenothera Missouriensis.

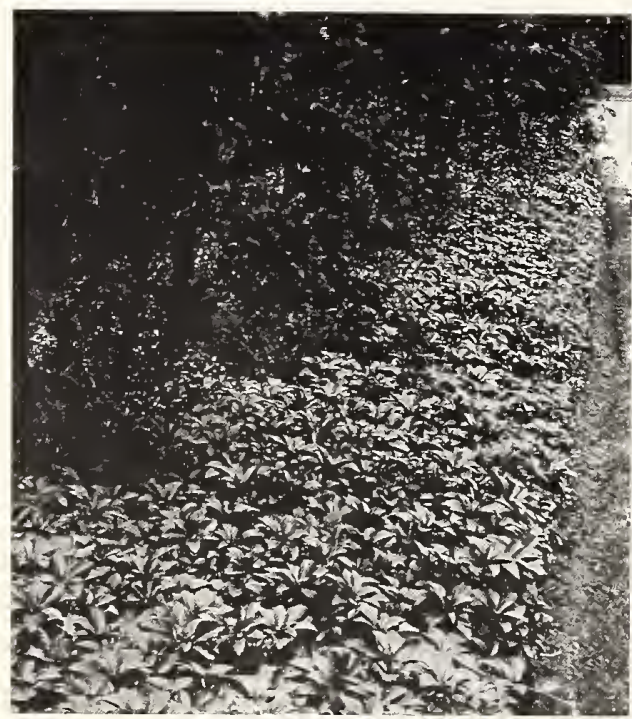

Pachysandra Terminalis.
MYOSOTIS (Forget-me-not).

Alpestris (Alpine Forget-me-not). Splen-
din for naturalizing in dry places; also

for beds, borders and rockeries .......\$1.50 $\$ 10.00 \quad \$ 90.00$

Falustris semperflorens. Large, rich blue

flowers with yellow eye; a charming

fuse bloomer than the Alpestris ........ $1.50 \quad 10.00 \quad 90.00$

Palustris, Pink Beauty. Pink-flowered

form of the above; very fine Forget-me-
not $\ldots \ldots \ldots \ldots \ldots \ldots \ldots \ldots \ldots \ldots \ldots \ldots$

NEPETA (Ground Ivy; Catnip; Catmint).

Mussini. An excellent plant for any position, but especially useful in the rock garden. Of dwarf, conpact habit, pro-

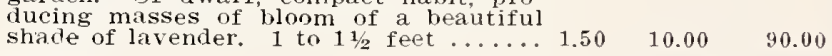

Ucranica

$1.75 \quad 12.00 \quad 110.00$

NIEREMBERGIA (Cup Flower).

Rivularis. A charming dwarf creeping Alpine plant, bearing large creamy white, cup-shaped flowels from June till Shite, cup-shaped flowels from June till the rockery. Plant in Spring only $\ldots \begin{array}{llll}1.75 & 12.00 & 100.00\end{array}$

OENOTHERA (Evening Primrose).

Elegant for a sunny position in the border or on the rockery, blooming all summer.

Fraseri. 1 foot. June to October. Flow- Doz. $100 \quad 1000$ ers large, pale yellow .............\$1.50 \$10.00 $\$ 90.00$

Fruticosa major. 2 feet. June to September. A strong growing plant, forming a dense, bushlike specimen; flowers

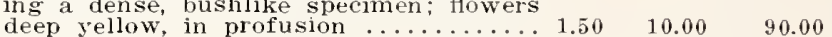

Missouriensis. 10 inches. June to August. A low species with prostrate, ascending branches; profuse bloomer. Solitary flowers, often 5 inches across. Good tor
rock garden or border ............ $1.50 \quad 10.00$

speciosa. Pure white flowers 3 inches across. 18 inches ................... $1.50 \quad 10.00 \quad 90.00$

Youngi. 2 feet. June to August. A strong, stocky, large-leaved plant with firm, shiny foliage; numerous bright lemonvellow flowers .......................... $1.50 \quad 10.00$

OROBUS (Bitter Vetch).

vernus. 1 foot. Bright blue and purple.

May .............................

PACHYSANDRA (Japanese Spurge).

Terminalis. A trailing plant 6 to 8 inches high, forming broad mats of bright glossy green foliage. A ground cover, which will grow in all shady situations and the only plant which will thrive under pine trees. Some of its main uses are: Under all evergreen plantings, under all shrub plantings, for areaway copings, for loggia and enclosed porch uses. for shrub and flower bed borders, for bordering walks and drives, for steep terraces in sun or shade, for city yards it is ideal, for dense shade under any kind of trees.

Strong, 3-inch pot plants with from Doz. $100 \quad 1000$ 6 to 10 leaves .............. $\$ 2.50 \quad \$ 1 \$ .00 \quad \$ 175.00$ Strong, 1-year, field-grown plants ... $1.25 \quad \$ .00 \quad 75.00$ 2-Jear plants ...................... $1.50 \quad 10.00 \quad 90.00$

\section{PARDANTHUS (Blackberry Lily).}

Very pretty perennial with lily-like flowers of a very handsome appearance. Pequires a rich soil.

Chinensis. Flower's orange colored, spotted Doz. $100 \quad 1000$ with purple-brown. is inches ......\$2.00 $\$ 15.00 \quad \$ 125.00$ 


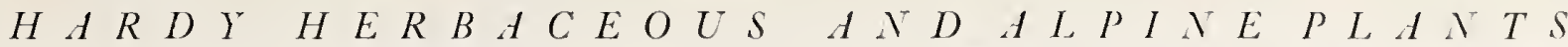

\section{PAPAVER - Poppy}

The proper planting season for Oriental Poppies is during the last of August, September and October. Roots planted at any other time we do not guarantee to live.

Oriental Poppies are the regal representatives of this popular genus, growing 3 to $3 \frac{1}{2}$ feet high, and far surpassing in splendor of bloom all the annual and biennial kinds, and for a gorgeous display of rich and brilliant coloring nothing equals them during their period of flowering in May and June, and whether planted singly or in niasses their large flowers and freedom of bloom render them conspicuous in any position. They are of the easiest culture; almost any kind of soil suits them, but they do best in deep, rich loam. Set the plants out in the Fall or early Spring before the first of May-give them water occasionally during dry spells in the early part of the season. Mulch with stable litter in the Fall; and they will increase in size and foriferousness for several years. ITe offer the best of the latest introductions, as well as the distinct standard rarieties. (Oriental Popp. Tremendous cup-shaped blooms of brightest climson-scarlet, with large, purplish black blotches at base of petals, creating a wonderful contrast when bloom is fully open. Clumps of these throughout the border add a brilliancy that no other flower can provide .......... $\$ 1.50 \quad \$ 10.00 \quad \$ 90.00$

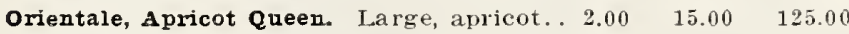
orientale, Beauty of Iivermore. Crimson. with black blotch; fine flowers ...... $3.00 \quad 20.00 \quad 180.00$

Orientale, Mrs. Perry. Orange-apricot;

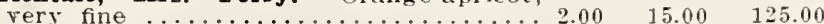

Orientale, Perry's White (New). The most distinct break in Oriental Poppies that has yet been made; the flowers are fine sating white with a crimson-maroon blotch at the base of each petal. (Sold out until next season).

PAPAVER NUDICAULE (Iceland Poppy).

The plant is of neat habit, forming a tuft of bright green fernlike follage, from which soring throughout the entire season, a profusion of slender, leafless stems 1 foot high, each graced with charming cup-shaped flowers.

Baker's Sunbeam Mixture Doz. $\begin{array}{rrr}100 & 1000\end{array}$ Miniatum flore pleno or Double Nudicaule. $1.50-10.00 \quad 80.00$

PENTSTEMON (Beard Tongue).

Most useful and showy perennials. Some varieties are not hardy. Those below are perfectly so. June and July. 3 feet

Barbatus Torreyi. Spikes of bright scarlet flowers from June till August. A very effective plant for hardy beds . . \$ \$1.50 \$10.00

Digitalis. White Foxglove-like spikes ... $1.50 \quad 10.00$ $\$ \$ 0.00$

Huntington's Shell Pink (New). A wonderful addition to this class. Spike is not as tall and "stringy" as Torreyi, and flowers are more plentiful on the spike. Color is a bricht, clean shell-pink. Perfectly hardy in any soil or climate....

Pabescens (Hirsutus). Stems $2 \frac{1}{\text { inches }}$ high covered with violet flowers often high, covered with violet flowers often producing flowers colored a flesh-pink, excellent for hot, dry place in the garden; is also a very fine wall plant. It stands hot, dry exposures as well as a
sedum. Do not fertilize this plant, except give it plenty of lime to bring out the color of the flowers ............. 3.50

Rupricaulis

$3.50 \quad 25.00$

Unilateralis

$3.50 \quad 25.00$

PHYSOSTEGIA (False Dragonhead).

Virginica. Forms large clumps 3 to 4 feet high, bearing long spikes of delicate pink llowers, tubular in form. July

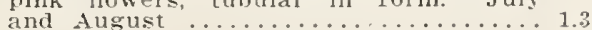

virginica, vivid. This is a seedling of our own: it blooms three weeks later than
the others and the flowers are a deeper color pink: much larger and better, lasting a long time when cut ............

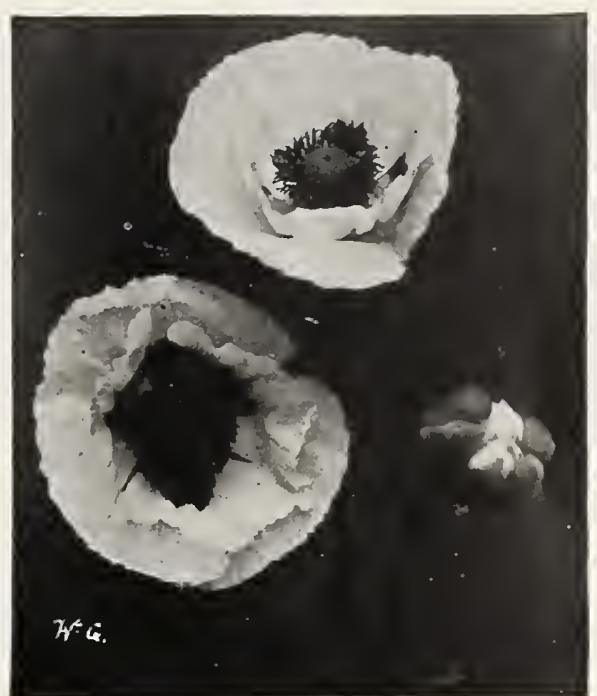

Papaver, Mrs. Perry.

The best of all the pink Poppies.

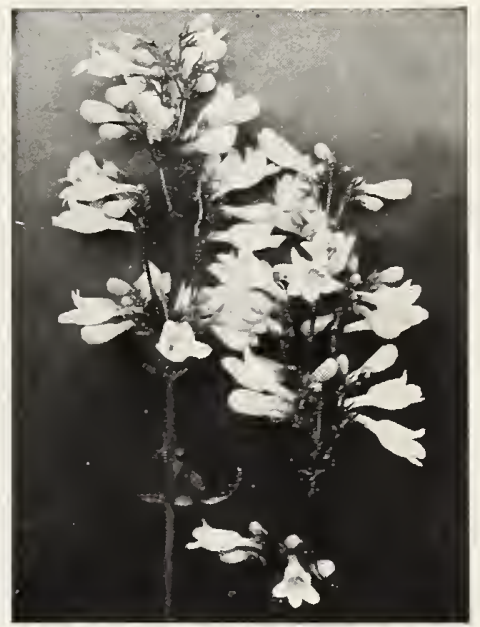

Pentstemon Digitalis. Does well in poor ground.

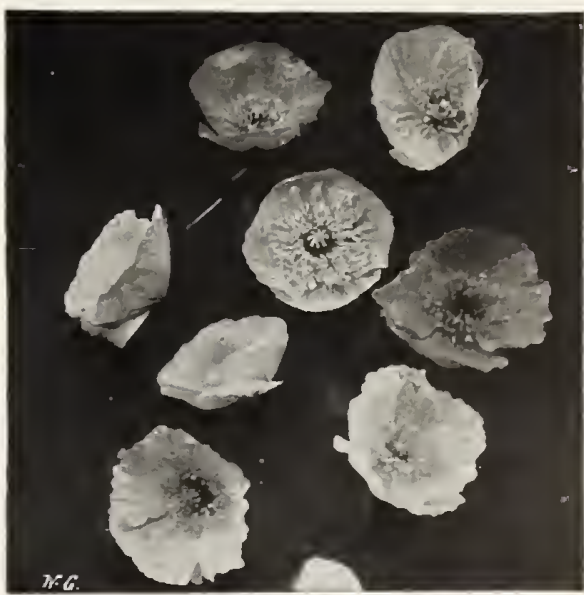

Papaver Nudicaule. 


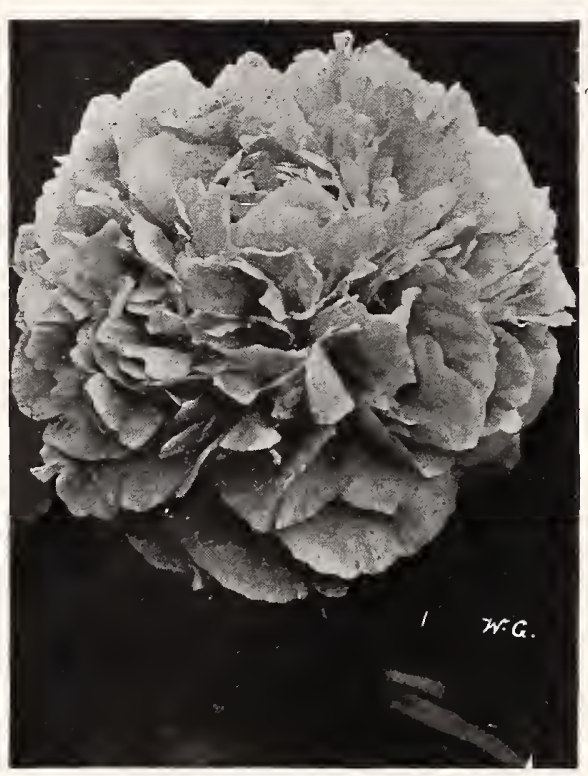

Couronne d'Or.

One of the best late white varieties.

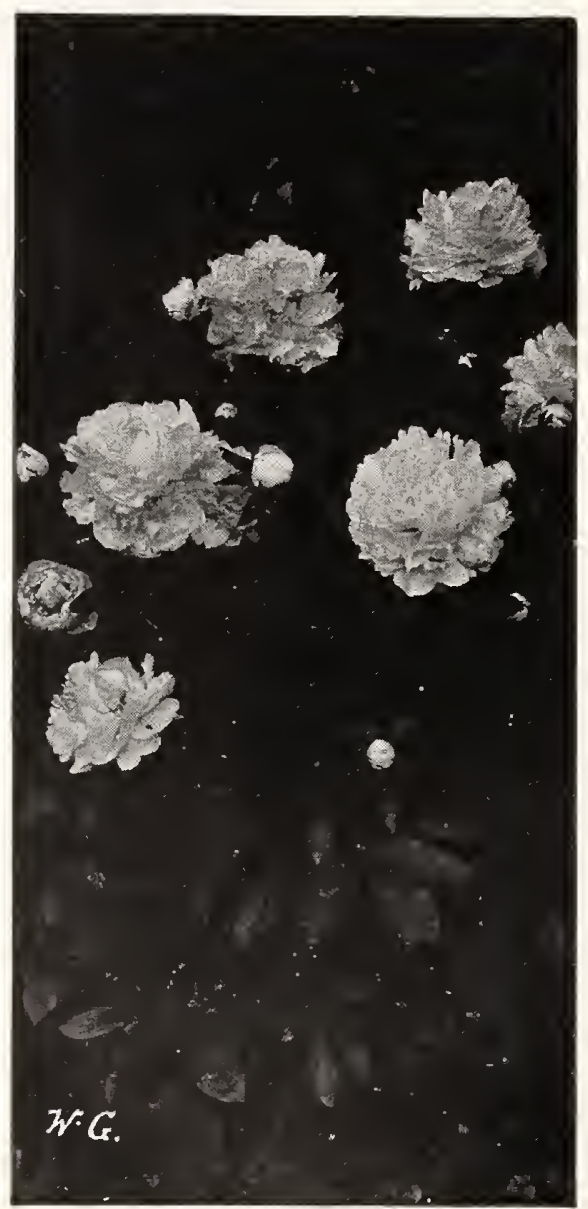

Duchesse de Nemours.

\section{Peonies}

The varieties we offer are arranged alphabetically, and where known, the name and date of the introducer immedlately follow's in parentheses. As color comes first in the choice of Peonies, we have placed the color on the same line as the name. Size and type naturally appeal next, and so follow the color.
Having found these satisfactory in any variety described, one naturally next looks for the character arid habit of the plant. To further aid purchasers we shall be pleased to give by letter further information to intending purchasers.

Figures following name indicate rating by American Peony Society

$$
\text { 3-5 Eyes }
$$

Albert Crousse. 8.6. (Crousse, 1893). Very fresh salmon-pinls delicate color. Large compact bomb shape; fragrant; erect: medium height. Late ..............

Albatre. 8.7. (Crousse, 1885). Milkwhite center, petals tinged lilac. Large, compact, rose type bloom; strong, vigorous grower and free bloomel. Midseason.

Avalanche. 8.7. (Crousse, 1886). Creamy white, slightly flecked with carmine. Large, compact crown type; fragrant: Large, compact crown type; fragrant
strong growth. Midseason ...........

Augustin a'Hour. 7.8. Bomb type: midseason. Extremely large; showy, perfectly built bloom. Color very deep. fectly built bloom. Color very deep.
rich, brilliant solferino-red with slight rich, brilliant solferino-red with slight
silvery reflex. It is a taller grower and silvery reflex. It is a taller grower and

Baroness Schroeder. 9.0. Rose type: late. White with shadings of flesh. This is one of the finest Peonies. Its immense flowers of great substance with high chalice-shaped center are freely produced, lasting a long time. Very fra-

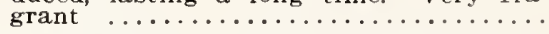

Boule de Neige. 8.0. (Cal., 1862). Very large, medium, globular, compact, semirose type. Milk-white, guards and center prominently flecked crimson. Tall, erect, free bloomer; extra good. Early

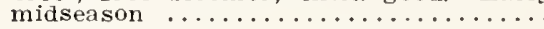

Couronne a'Or. 8.1. (Calot, 1873). White with yellow tints arising from a few stamens showing amidst the petals. Center petals tipped with carmine Large, rather full flower of superb form. Strong grower and very flee bloomer.

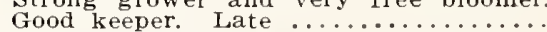

Duchesse de Femours. 8.1. (Calot. 1856). Guard petals white, center lemon-yellow, cup-shaped; at first it develops into a large bloom, gradually fading to white; fragrant; strong grower and free bloomer. Extra good commercial variety. Follows two to three days later than Feslows two to three days later than Fes-

Eaulis Superba. 7.6. (Lemon, 1834). Dark pink, even color; large, loose, flat crown when fully open. Very fragrant; upright when fully open. Very fragrant; upright growth; early bloomer. One of the best
commercial Peonies. There is much commercial Peonies. 'There is much
confusion over this variety being sold under twenty or more different names..

Eugenie verdier. 8.6. Late. Very large, compact blooms of pale hydrangea-pink, grant; extra strong stems ..........

Felix Crousse. 8.4. (Crousse, 1881). Very brilliant red. Medium to large, globular, growth. Stems rather weak. Midseason $\ldots \ldots \ldots \ldots \ldots \ldots \ldots \ldots \ldots \ldots$

Floral Treasure. 7.5. (Ros., 1900). Very large, showy: rose type. Pale lilac-rose. Fragrant. Strong, tall, upright grower free bloomer. One of the best commer-

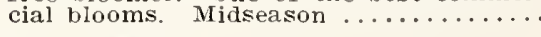

Festiva Maxima. 9.3. (Miellez, 1851). Paper-white, crimson markings in center. Very large and full, rose type; very tali, strong growth. Early ..........

Germaine Bigot. 8.5. (Des., 1902). Very large, medium compact, flat crown. Pale lilac-rose, center prominently flecked crimson, 2 (130). Strong, erect, medium height; free bloomer: midseason .....
$\$ .00 \$ 60.00$

$6.00 \quad 40.00$

$6.00 \quad 40.00$

$5.00 \quad 35.00$

$6.50 \quad 45.00$

를

类

$\overbrace{}^{2}$

:

ह

$\stackrel{+}{*}$

舫

通

$4.50 \quad 30.00$

류

$\Xi$

$4.50 \quad 30.00$

$\xi$

\%

导

$10.00 \quad 70.00$

(6)

$5.00 \quad 35.00$

总

$4.50 \quad 30.00$

$8.00 \quad 60.00$
$5.00 \quad 35.00$

$6.00 \quad 40.00$ 
PEONIES-Continued. $3-5$ Eyes
Doz. 100

Karl Rosenfield. 8.8. Very large flower: globular, semi-rose type. Extremely vigorous grower, tall, and free-flowering. As an early red it has no equal $\ldots \$ 12.00 \quad \$ 95.00$

Kelway's Glorious. 9.8. Flowers large, full, double rose type; cream-white, overlaid with a soft blush of rose; very exquisite; fragrant; late midseason. Considered by many as the finest of Kelsidered by many as the finest of Kel-
way's Peonies. (Sold out for this seaway's
son).

Iady Alezandra Duff. 9.1. Delicate pale pink fading to white. Main flower large. pink fading to white. Main flower large, side buds often semi-double, exposing the anthers; fragrant $\ldots \ldots \ldots \ldots \ldots \ldots \ldots 50.00$

Ie Cygne. 9.9. Very large, perfectly formed flower, freely produces; creamwhite with a touch of green at the heart. The finest white. Received the highest rating out for this season).

Mme. Crotase. 7.9. Pure white with faint crimson markings. Large, globular, crown type; fragrant; medium height

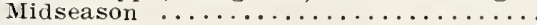

Madame Ducel. 7.9. (Mech., 1850). Large, globular, typical bomb. Light mauve rose, 1 (153), with silvery reflex. Fragrant. Strong grower, medium height

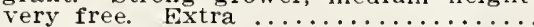

Mme. Emile Galle. 8.5. (Crousse, 1881). Very soft pink, changing to milk-white in center. Very large, compact, flat, rose type; tall, strong, fragrant. Late ....

Mme. Forel. (Crousse, 1881). Enormous, very full, double bloom; color glossy, deep pink with a silvery reflex; known as the "Princess of Pink Peonies," a title it well deserves and proudly carries.

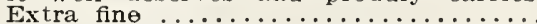

Mile. Ieonie Calot. 8.1. (Calot, 1861). Very delicate shell pink, center darker. dium size, very compact, globular; on weak stems. Late midseason ........

Marie Iemoine. 8.5. (Calot, 1869). Pure white with cream-white center. Large, very compact, rose type; pleasing fragrance; medium height; extra strong stems. Very late .................

Marguerite Gerard. 8.4. (Crousse, 1892). Very pale salmon-pink, fading to almost white. Large, compact, rose type; very

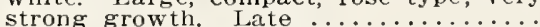

Marie. 8.5. (Calot, 1868). Lilac-white fading to milk-white. Medium size compact, rose type; fragrant; very tall.

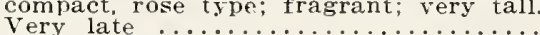
Very late $\ldots \ldots \ldots \ldots \ldots \ldots \ldots \ldots \ldots \ldots \ldots \ldots \ldots \ldots$.

Modeste Guerin. 7.8. (Gr., 1845). Large compact, typical bomb. Uniform solferino-red. Fragrance XX. Medium height; extra strong; free bloomer. Midseason.

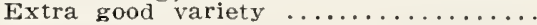

Mons. Dupont. 8.3. Very large, cupshaped flower: ivory-white; center petals splashed with carmine. The golden stamens show at the base of the petals fragrant; a strong grower: very tall midseason. (Sold out for this season).

Mons. Martin Cahuzac. 8.8. Medium sized globular, semi-rose type. Dark purplegarnet with black reflex. The darliest Peony known. Strong, vigorous grower, Peony know

free bloomer: midseason ...........25.00

Martha Bulloch (Brand, 1907). Mammoth cup-shaped blossom often 9 to 12 inches across. The largest of the good Peonies. Deep rose-pink in the center, shading to silvery shell-pink in the outer petals. Stalks strong and erect. (Sold out for this season)
4.50

5.00

35.00

6.00

40.00

5.00

35.00

6.00

40.00

6.00

40.00

5.00

35.00

.00

50.00

\section{$\mid$}$$
\text { ) }
$$

(

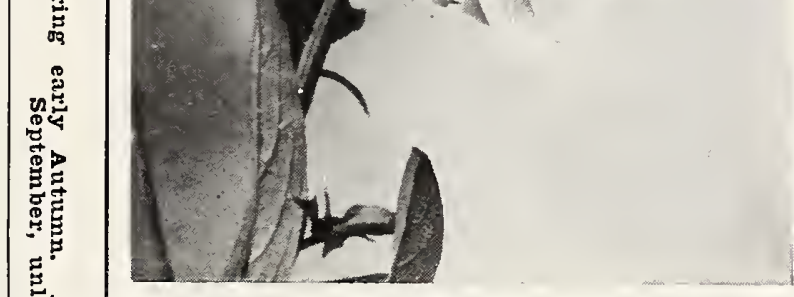

总

芒草

A very good pink garden variety, also good cut

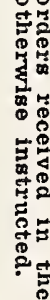

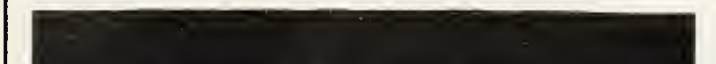

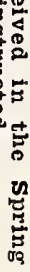

-

$-1$

Man

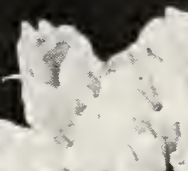

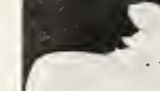
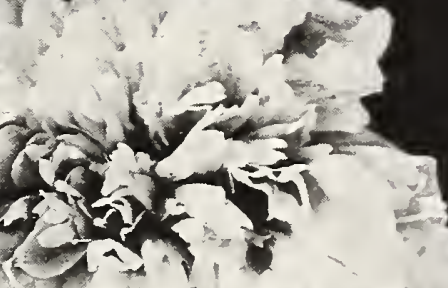

ष्म

疍

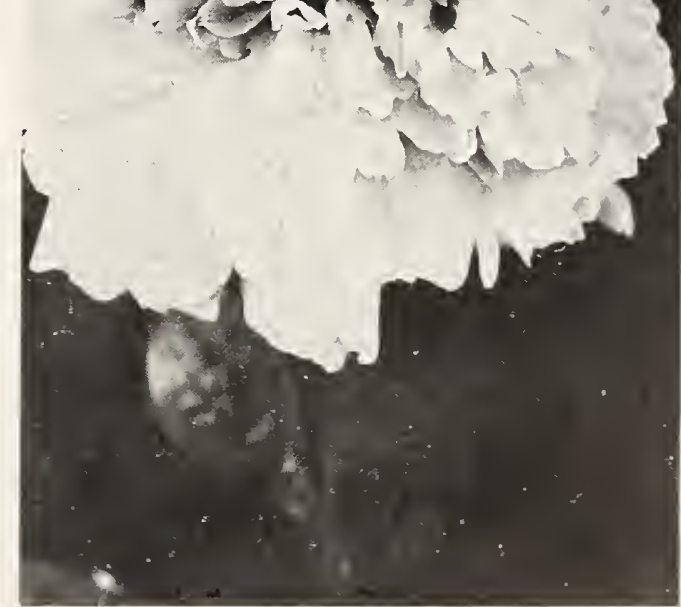

Mad. Crousse. 


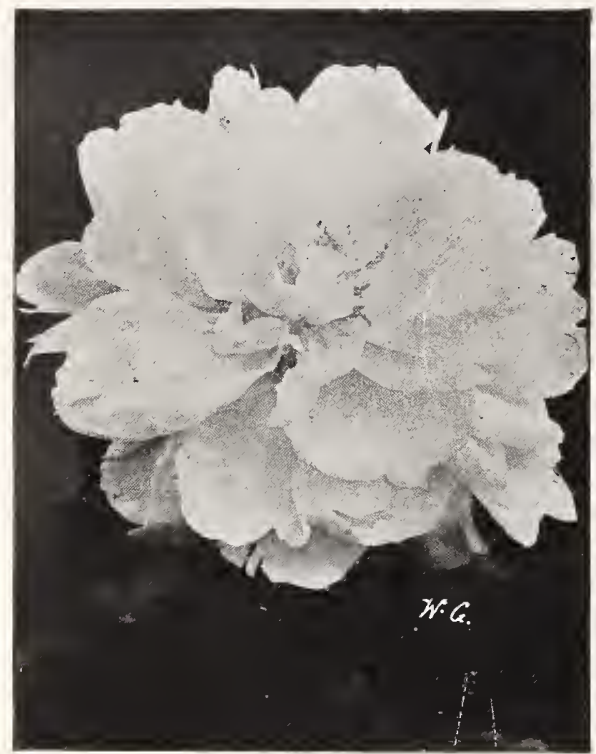

Festiva Maxima.

No garden complete without this white Peony. We consider it the best all around white kind in cultivation.

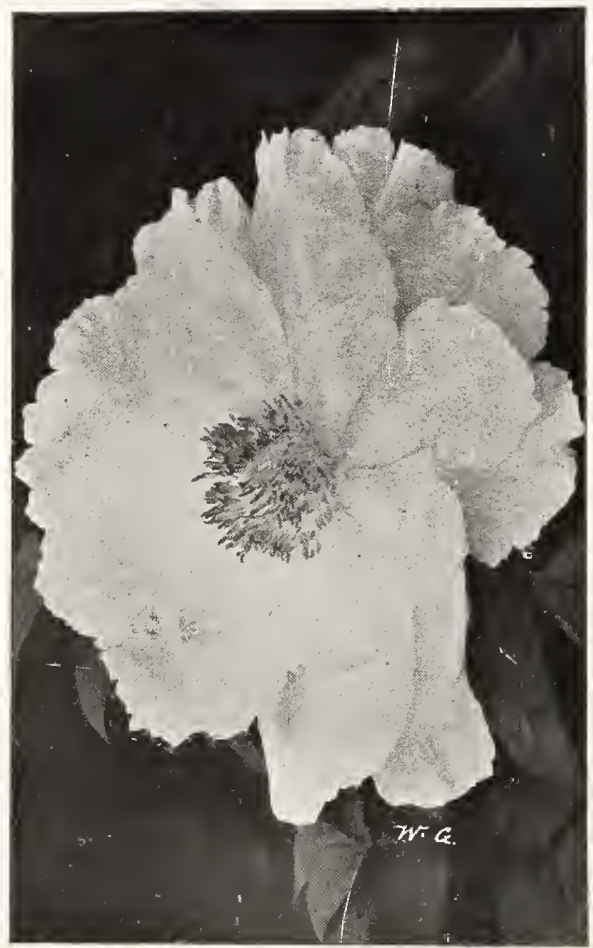

Japanese Peony.
PEONIES-Continued. $\begin{array}{cc}3-5 & \text { Eyes } \\ \text { Doz. } & 100\end{array}$

Octavie de May. 8.5. Very large, flat clown. Guards and center pale hydrangea-pink, collar almost white. Rather dwarf habit; but free, fragrant, midsea-

Officinalis Rubra fl. pl. Rich deep crimson; the great Decoration Day Peony .......

President Taft. \$.7. A vigorous, strong grower, a profuse bloomer, every shoot being crowned by a big bloom. The may be Peony flowers as large, but none larger. The color is a delicate hydrancea-pink completely enveloped in a gea-pink, completely enveloped in a halo of angelic white. The fragrance is
delicious. It is certainly a glorious, gorgeous flower, very large and double

Rubra Superba. 7.2. (Richardson, 1871). Deep carmine-crimson. Large; fragrant, rose type; medium heiglit. Very late

Sarah Bernhardt. 9.0. Late. Flat, compact, semi-rose type. Uniform mauve rose, silver tip. Erect, tall, free ......

Solange. 9.7. Flower very large compact; rose type; outer petals delicate waxy
white, deepening toward the center with white, deepening toward the center with of the most beautiful Peonies in existof the most beautiful Peonies in existence; a strong grower and a late, free

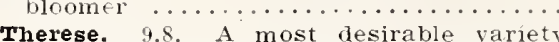
of a charming shade of violet-rose, of a charming shade of violet-rose. changing to lilac-white. Develops high crown; strong grower and very free bloomer. A splendid addition to the mid-
season sorts of which it is one of the season sorts of which it is one of the

venus. S.3. (Kelway). Exquisite pointed buds, opening into large, compact flowers of delicate shell-pink with a colla of flesh-white. Extra good both as a garden flower and as a cut flower. One of the best in our collection. Midseason. $6.00 \quad 40.00$
$6.00 \$ 40.00$

$7.00 \quad 50.00$

$6.00 \quad 40.00$

$25.00 \quad 200.00$

(1)

\section{NEW JAPANESE PEONIES}

A type not very generally known, but in every community, wherever established, is awakening great interest and enthusiasm. The opened flowers are of extra wide spread, with one or more layers of broad guard petals which act as a cup to the mounded center. In place of the pollen-bearing stamens which center the Single Peony flowers, in this class the stamens and anthers are greatly enlarged into narrow, thick, twisted petaloids of various colors, forming a dense cushion.

We heartily recommend our list to those who want something different from the other fellow's: and to Peony planters generally, as types which will add zest and beauty to their gardens.

Orders for the following booked now for September delivery. Strong Divisions,

Fo. 6. Gunpoo-no-nishiki. All-over violet rose, lower 6.00 No. 11. Yoochi-no-tsuki. six- to eight-inch flowers with prominent cushion center; white, occasionally flushed

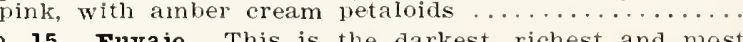

No. 15. Fuyajo. This is the darkest, richest and most distinctively Japanese of our group. Broad rounded guards of dull-although velvety-mahogany. The fine, eurly petaloids form a conspicuous, dense center:
garnet, streaked on rererse side and heavily tipped

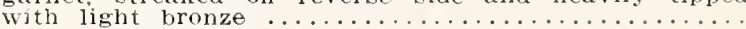

No. 20. Fuji-no-mine. A very large and free-blooming sort; white, with rich cream center ...................... No. 42. "Rose of Nippon." A wondertully free bloomer, rose, the broadly prominent center darkened by carmine, and illuminated by countless starpoints of both silver and gold. Many centers are slightly tufted

No. 47. Fuji-zone-gorono. Inexpressibly beautiful in its matchless symmetry and delicate color tones. Immense, flattened, poppy-shaped flowers borne very freely. The two-layered guards are broadly rounded an exquisite wo-layered guards areria-pink. The crinkly cushion is pure gold, toned warmly towards the base with coral. pure gold, toned warmly towards the base with co....

No. 88. Oki-no-nani. Tall, free-flowering and show. Pale hydrangea-pink; with full, fine-cut center of peachpink and cream. It does not require a strong imagination to get the Japanese descriptive impression ……
o. 135. Kara-ori-nishiki. This shows uniquely tluted petals, with ends deeply inclented. These are white, irregularly streaked and tipped with lilac-red. The center is medium sized, but bright with deep gold

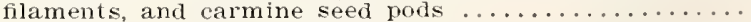




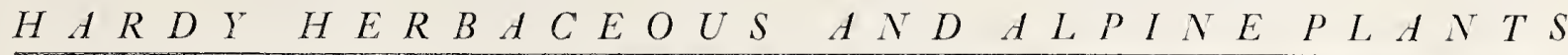

\section{PHLOX}

PHLOX DECUSSATA (Hardy Phlox).

Perennial Phloxes succeed in almost any soil enriched with manure in Spring, and in lot weather an occasional soaking of water. If the first spikes of bloom are removed as soon as over they will produce a second supply of flowers, continuing the display until late in Autumn. These later blooms are often finer than the first.

(We offer nothing but strong, field-grown plants).

Athis. Deep, clear salmon. Very fine ...\$1.40 $\$ \frac{100}{8.00} \quad \$ 7000$

Africa. Ruby-crimson with darker center. $4.50 \quad 35.00$

Antonin Mercie. Clear lilac with white

eye. Extra large .................. $1.75 \quad 12.00$

Beacon. Brilliant cherry-red ......... 1.75 12.00

B. Comte. Rich satiny amaranth ..... 2.50 15.00

110.00

Clara Benz. Brilliant rosy carmine, with

white eye and violet halo; medium tall. $4.50 \quad 35.00$

Champs Elysee. Fine, rich crimson .... $1.50 \quad 10.00$

Commander. Beautiful. New. Crimsonred with darker eye. The most striking of Phloxes ........................ 2.00 15.00

Evelyn. Rich salmon-rose; flowers large and of perfect form. 3 feet ........ 4.50

Graf zeppelin. White with red eye; better than Europa ............. 4.50 35.00

Eiffel Towex. Pink with deep pink eye. Very tall grower .................... 3.00 20.00

Elizabeth Campbell. Bright salmon-pint, with lighter shadings and dark red eye; one of the handsomest and most at-

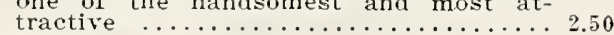

Ethel Pritchard. Grand light lilac ..... 3.00

Europa. A new variety, white with large and truss .............................. $1.50 \quad 10.00$

xnerbrand. Bright vermilion-scarlet. New variety ................................

Imperator. Brilliant, dark carmine-red flowers, with darker eye ............. $4.50 \quad 35.00$

Jules Sandeau. Large, fine very free flowering pure pink ............... $1.25 \quad 8.00$

Ia vague. An improvement over older varieties of similar color, with immense,
conical heads, borne in great profusion. Warm mauve with emphatic carmine eye $\ldots \ldots \ldots \ldots \ldots \ldots \ldots \ldots \ldots \ldots \ldots \ldots \ldots \ldots \ldots \ldots .25$

Miss Iingard (Sfe page 42) ........ 1.50

Mrs. Jenkins. White; immense panicles;

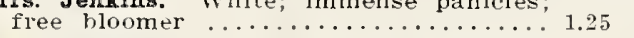

Mrs. Scholten. New. Dark salmon-pink flowers in enormous pyramidal spikes. 3.50

Mrs. Mally van Eoboken. New. Soft pink, without eye Larse flowers on long erect spike........................ 3.00

Prof. Verschouw. Bright carmine, overlaid with orange-scarlet .................... 1.75

Pantheon. Clear, deep, carmine-pink with

faint halo $\ldots \ldots \ldots \ldots \ldots \ldots \ldots \ldots \ldots \ldots \ldots 1.75 \quad 12.00$

Rheinlander. A beautiful salmon pink, with flowers and trusses of immense

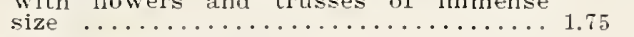

R. F. Struthers. Bright rosy-carmine,

with claret-red eye ..................... $1.50 \quad 10.00$

Rijnstroom. Lively rose-pink, much like Paul Neyron rose. Immense trusses of
flowers $\ldots \ldots \ldots \ldots \ldots \ldots \ldots \ldots \ldots \ldots \ldots \ldots$

Thor. A beautiful lively shade of deep salmon-pink, suffused and overlaid with a scarlet glow; has aniline-red eje ... 1.50

Vald Jensen. Beautiful salmon-pink with white eye. One of the newest and best. 4.50

Von Lassburg. Splendid pure white; very large trusses; free bloomer; medium

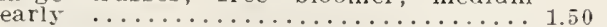

White Lady. Very fine late pure white .. 1.25
18.00

20.00

25.00

8.00

10.00

8.00

25.00

20.00

12.00

12.00

8.00

10.00

35.00

10.00

8.00
225.00

70.00

110.00

125.00

90.00

125.00

180.00

170.00

190.00

90.00

70.00

90.00

70.00

225.00

180.00

100.00

100.00

100.00

90.00

70.00

90.00

90.00

70.00

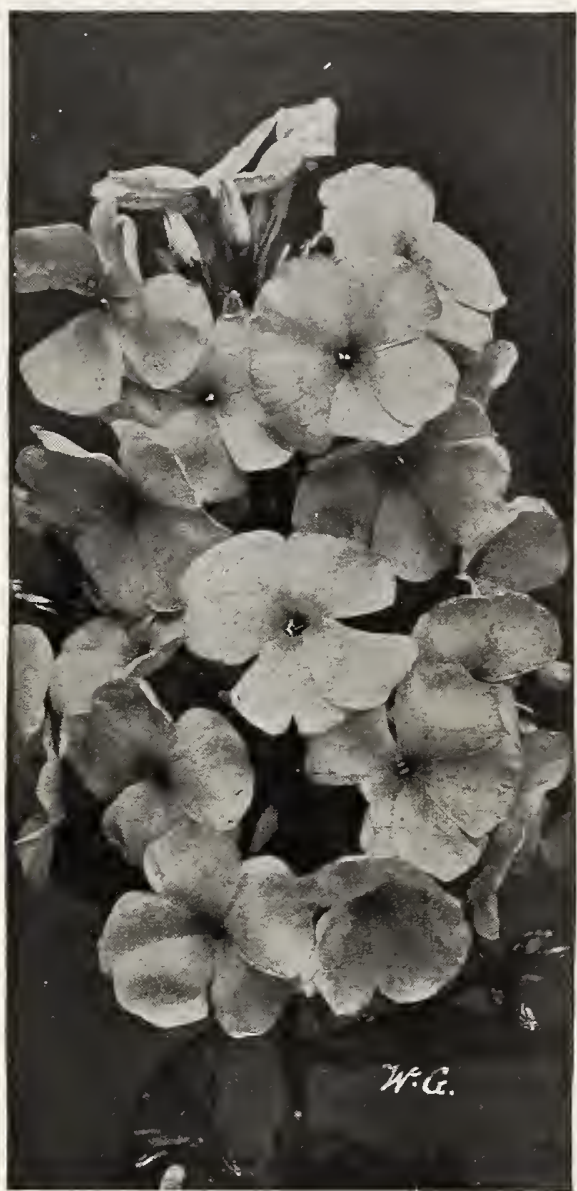

Phlox, Miss Lingard.

Is the most satisfactory white Phlox known.

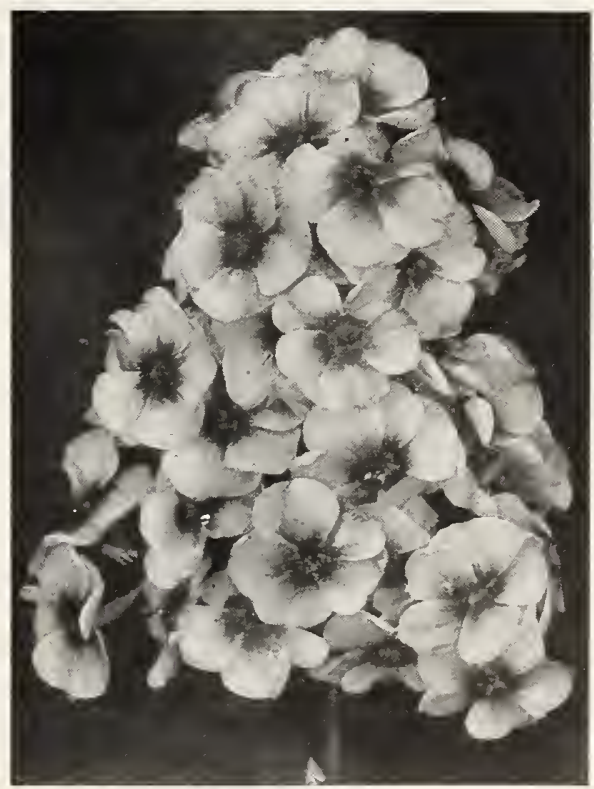

Phlox, Europa. 


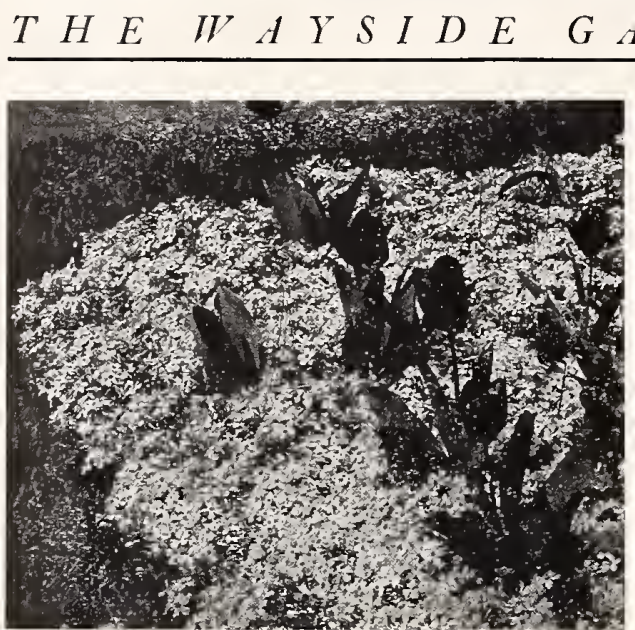

Phlox Subulata.

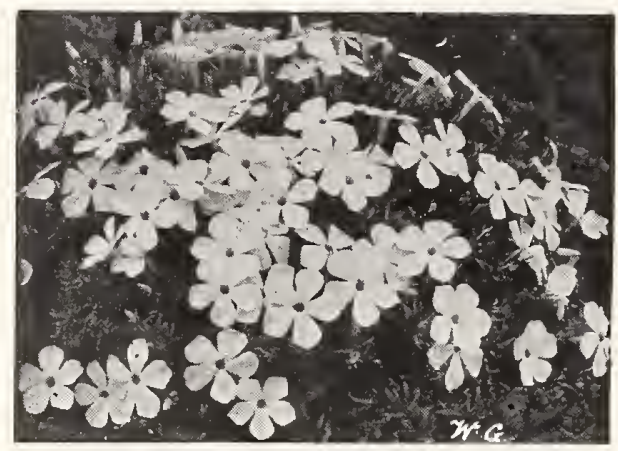

Phlox Amoena.

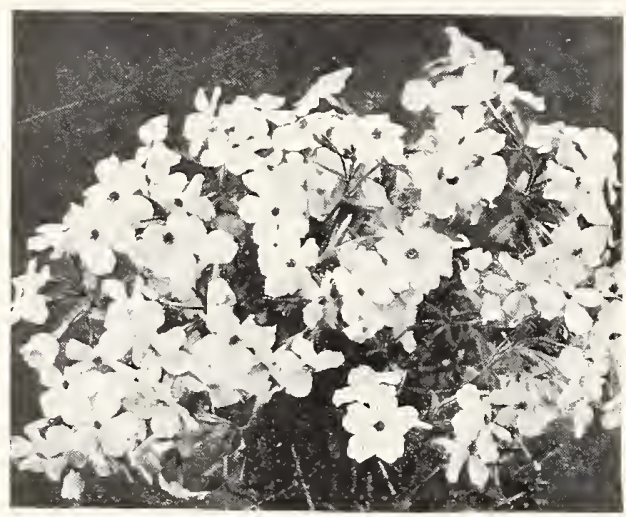

Phlox Divaricata.

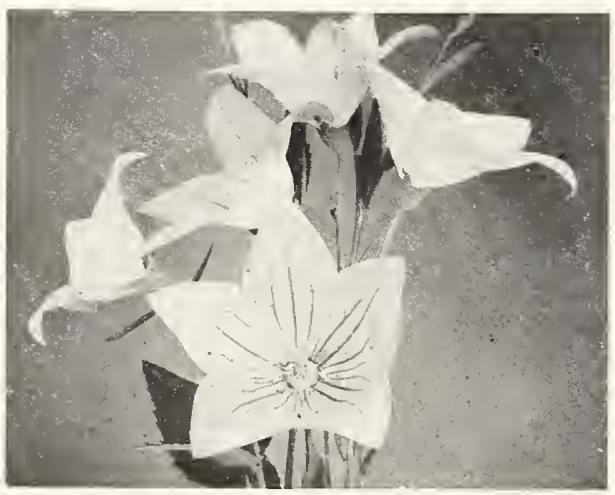

Platycodon.

\section{PHIOX SUFFRUTICOSA}

An early-flowering type with flower heads quite as large as the Decussata type.

Belle Pyramide. Same habit as Lingard, but color is rose-pink $\ldots \ldots \ldots \ldots \ldots \ldots$..... $\$ 35.00$

Miss Lingard. The best Phlox in cultiva-

tion. It produces immense heads of

beautiful white flowers in June and

ber. Splendid foliage and habit, and

free from attacks of red spider. Better

results will be had if old flowers are

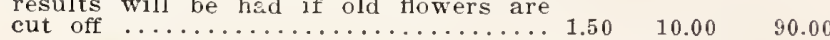

PHIOX SUBULATA (MOSS or Mountain PInk).

An early Spring-flowering type with pretty mosslike, evergreen foliage, which during the flowering season, in April and May. is hidden under the masses of bloom. An excellent plant for the rockery, the border, and invaluable for carpeting the ground or covering graves.

Alba. Pure white

Iilacina

Rosea. Rose-pink. Fine for covering banks; thrives in hot, dry situations, and

blooms profusely $\ldots \ldots \ldots \ldots$................

that this is the finest free-flowering

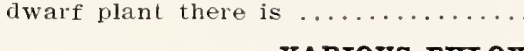

\section{VARIOUS PHLOX}

Amoena. 'This is one of the best varieties for carpeting the ground, the rockery or the border. It grows but 4 inches high, and in spring is a sheet of rich bright pink flowers $\ldots \ldots \ldots \ldots$.............. species, which is worthy of extensive planting, commencing to bloom early in April, and continuing through May, with large, fragrant, lavender flowers on stems 10 inches high

Maculata. Very much like a rosy red

Miss Lingard. Mree-flowering; good for poor, sandy soil ………....

Ovata (Carolina). Bright rosy red flowFilosa splendens. A new Spring-flowering Phlox that produces great masses of
lilac-rose flowers. 1 foot. May ...... Doz. $\quad 100 \quad 1000$ $\$ 1.50 \quad \$ 10.00 \quad \$ 90.00$ $\begin{array}{rrr}1.50 & \$ 10.00 & \$ 900 \\ & & 90.00\end{array}$ $1.50 \quad 10.00$ 90.00 $3.00 \quad 25.00$

YSALIS (Chinese Lantern Plant)

Francheti An ornamental variety of the Winter Cherry, forming dense bushes about 2 feet high, producing freely its bright orange-scarlet, lantern-like fruits, which, when cut, will last all Winter. Very attractive plant

PINKS (Hardy Garden). (See Dianthus).

PLATYCODON (Balloon Flower).

Grandiflora. Blue. 18 inches. June to October. Large, showy, deep blue flowers. Good for rock garden and border. the above $\ldots \ldots \ldots \ldots \ldots \ldots \ldots \ldots \ldots \ldots \ldots$ until late September. A beautiful dwarf species, with broad, thick foliage and large, deep violet-blue flowers ........... mariesi alba. White-flowered form of the LUMBAGO (Leadwort)

PLUMBAGO (Leadwort). most desirable
Iarpentae. One of the most $\mathbf{L}$ arpentae. One of the most desirable
border and rock plants. It is of dwarf, spreading habit, growing 6 to 8 inches high, covered with deep blue flowers during the Summer and Fall .........2.50 15.00

POLEMONIUM (Jacob's Ladder).

$\begin{array}{llll}\text { Album. A white variety of the preceding. } 1.75 & 12.00 & 100.00\end{array}$

Coeruleum (Richardsoni). Erect stems of sky-blue flowers. 1 to $1 \frac{1}{2}$ feet. June

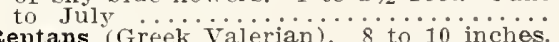
Reptans (Greek Valerian). 8 to 10 inches. graceful growth. Showy blue flowers. Rock garden and fine border plant.... $75 \quad 12.00$ 100.00

POLYGONATUM (Solomon's Seal).

Multiflorum major. Pendent sprays of greenish white flowers borne on long stems. 2 feet. May and June. A grand plant for a shady position, where it has plenty of room to show its pendulous sprays of bells. Fine for cutting .... 2.00 15.00 


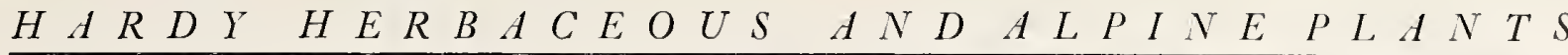

\section{PRIMULA - Hardy Primrose}

Splendid little plants for naturalizing near shrubs, in the border or shaded nooks on the rockery.

"Ailin Aroon." Another cross between pulverulenta and Cockburniana; flowel's light scarlet $\ldots \ldots \ldots \ldots \ldots \ldots \ldots \ldots \ldots \ldots 5.00 \quad \$ 35.00$

Auricula alpina. One of the treasures of the rock garden. The growth is rery attractive, forming rosettes of thick leaves, sometimes farinose or mealy. From these rosettes the flower stalks rise to a height of six or eight inches bearing heads of bloom of various colors and exceedingly fragrant $\ldots \ldots \ldots \ldots \ldots 3.00 \quad 20.00$ 180.00

Bullezana. A beautiful species from Yunnan. Flowers rich golden yellow, shaded orange-buff borne in whorls on stiff orangeCashmeriana (New). Large, globular
heads of a pleasing purplish blue shade; prefers a moist shaded situation $\ldots \ldots 3.00 \quad 20.00 \quad 190.00$

Cortusoides. A distinct Siberian species, with soft, wrinkled heart-shaped leaves. Flowers in early suminer, deep rose. Prefers light, rich, well drained soil, in a sunny position, in border or rockery;

a sunny position, in border or rocke.

Moerheim Hybrids. A new strain of Hardy Primulas with the constitution of $\vec{P}$. japonica, resulting from crossing of several. Colors range from cream to many shades of yellow, orange, purple, lilac, pink and crimson. They are very hardy and prefer a half-shaded position that is fairly moist; very unusual ... $3.50 \quad 25.00 \quad 225.00$

Pulverulenta. Rich crimson in color, in whorls, on stems 3 feet high. One of

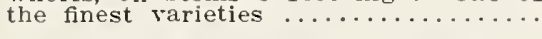
Vulgaris. The old English Primrose with
pale yellow fowers ................... $30 \quad 25.00 \quad 225.00$ $3.50 \quad 25.00 \quad 225.00$

\section{POLYANTHUS (Bunch Primrose).}

The Polyanthus is an indispensable spring flower and should be used largely in flower beds and borders, also wild gardens and rockeries. It likes an open, half-shady position in rich soil and under such conditions will bear flower stems a foot high.

Fonibition Blue A roz. 100

1000

having flowers from deep to Iight blue..\$5.00 $\$ 35.00$

Exhibition white. A very fine, largeflowered pure white, with striking yel-

low eye pure white, with striking yel- $3.00 \quad 20.00 \quad 180.00$

Munstead Strain. In shades of yellow, from cream to dark orange, selected and perfected by Miss Jekyll of England. $3.00 \quad 20.00 \quad 180.00$

Pink and Red Shades. Very handsome, ranging from light to dark red, with yellow eye $\ldots \ldots \ldots \ldots \ldots \ldots \ldots \ldots \ldots \ldots 3.00 \quad 20.00 \quad 180.00$

Veris Eybrids. This strain includes various shades of lilac, purple and violet, as well as a wide range of buff, orange, salmon and rich reds approaching scarlet in intensity Quite hardy and of

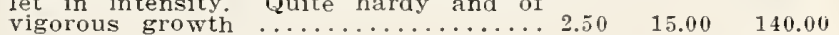

\section{POTENTILLA (Cinquefoil).}

Charming plants for the border, with brilliant single or double flowers that are produced in profusion from June to August. Succeeds in any soil. 18 inches.

Mixed Colors of Double Varieties ...... $\begin{array}{ccc}\text { Doz. } & 100 & 1000 \\ \$ 1.50 & \$ 10.00 & \$ 90.00\end{array}$

PRUNELLA (Self-heal; Heal-all).

Grandiflora. Violet or purple flowers all Summer. Fine for the rockery or slight-

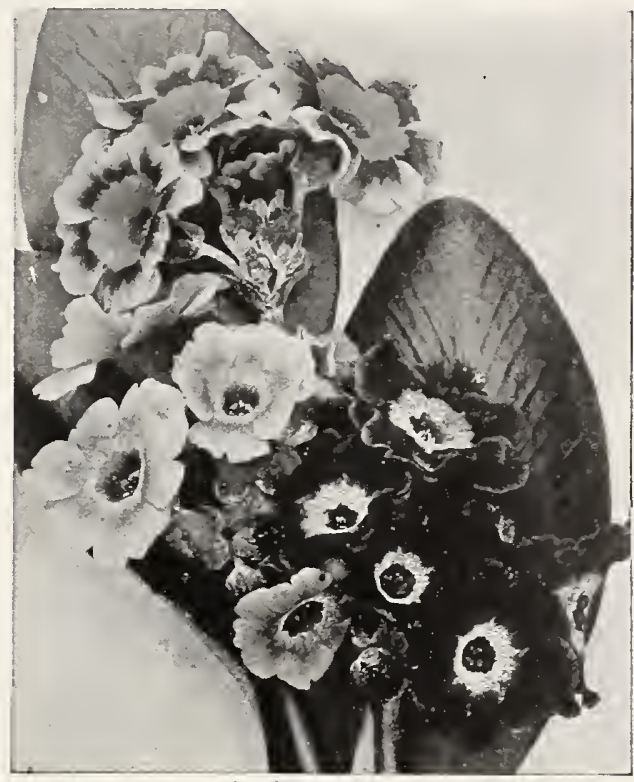

Primula Auricula.

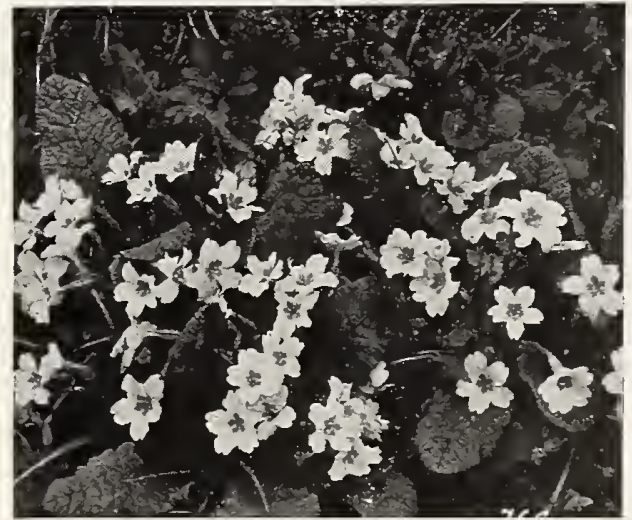

Primula Vulgaris.

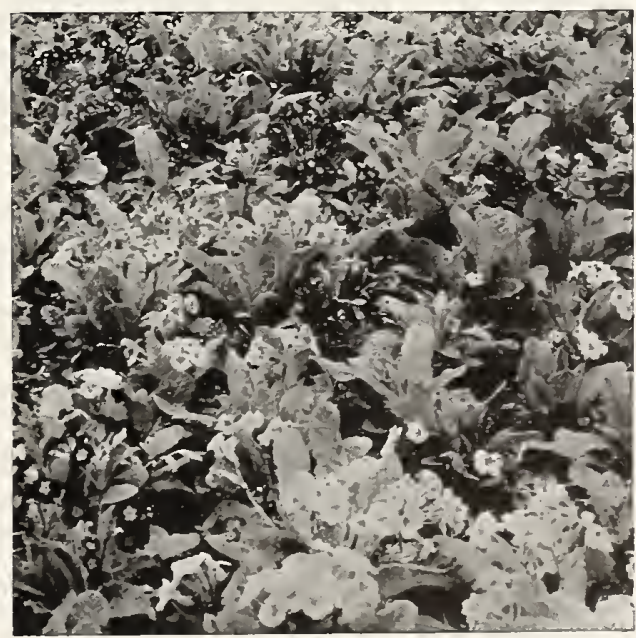

Primula Veris Polyanthus-Bunch Primrose. Hardy Variety. 




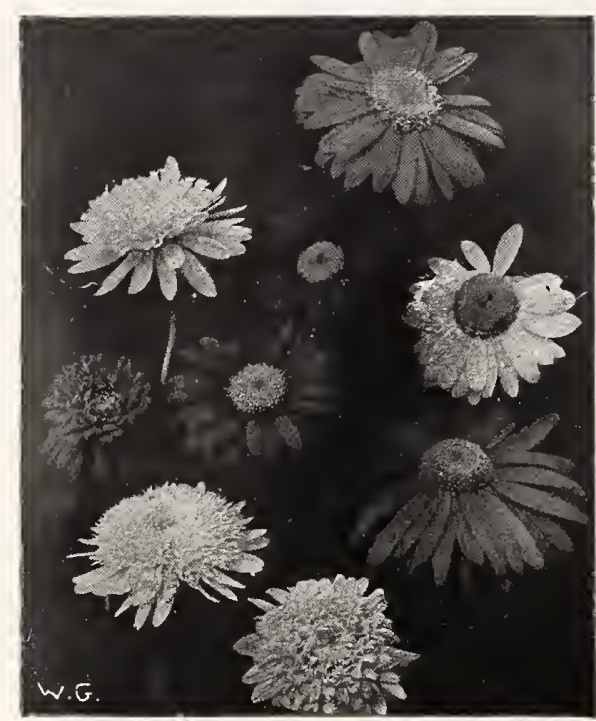

Pyrethrums.

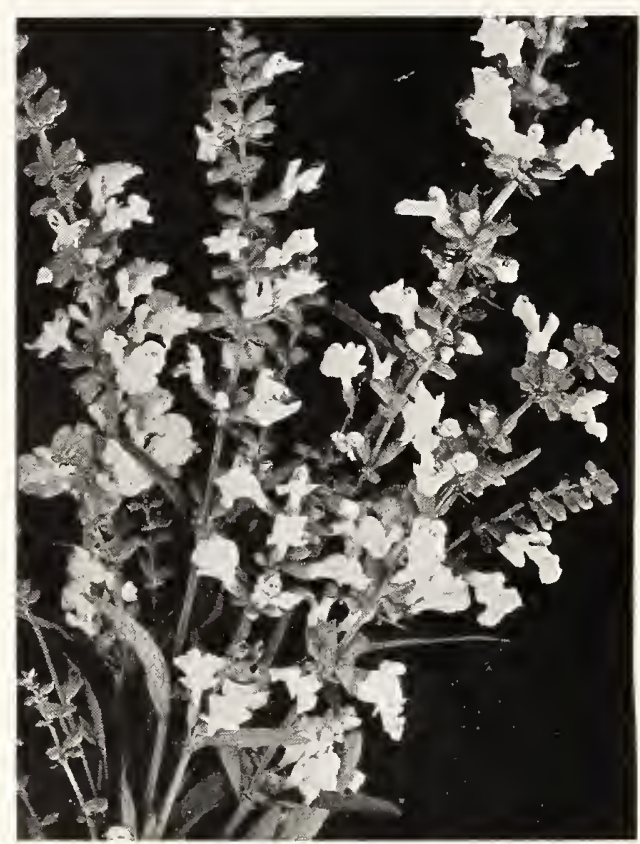

Salvia Azurea.

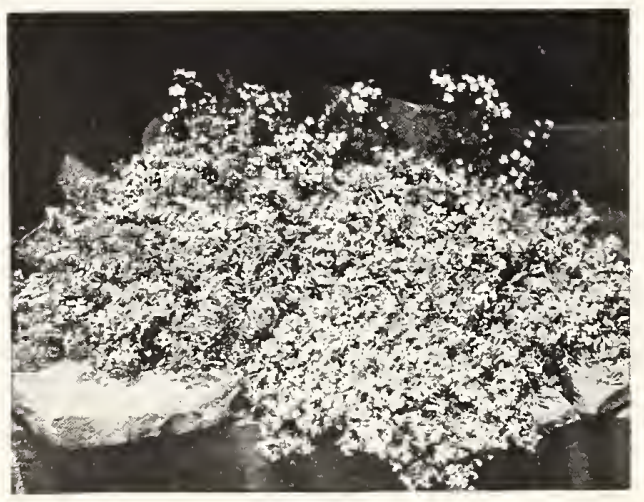

Saponaria.
PYRETHRUM (Persian or Painted Daisy).

The Pyrethrums are so simply and easily cultivated that they may be lecomniended to all who possess a garden. They are perfectly hardy and absolutely invaluable for cut flowers through the summer and early Fall. The flowers are bright and elegantly borne on long steins; most convenient for decoration. The single-flowered varieties are veritable colored Marchrysanthemum-like, and as their chief beauty is in the months of May and June, they may well be designated Spring Chrysanthemums, possessing the advantage over the Chrysanthemums of being able to withstand the severest Winter without protection The single-flowered varieties are variable colored MIarsuerites and possess a range of color and hardiness that Marguerites might enir in vain. Nothing can surpass the Prrethrum in profusion of flowers throughout the entire Summer from May to July, and the blossoms are not injured by storm or sun. As a cut flower, their long stems make them ideal for decorative purposes. Their position should be in the border or in beds.

Finest Mixed of English Double and Single

Varieties. Strong, 1-year elumps ...\$1.50 \$10.00 \$ $\$ 90.00$ Strong, 2-year clumps $\ldots \ldots \ldots \ldots \ldots \ldots 2.00 \quad 15.00 \quad 130.00$

RANUNCULUS (Buttercups).

Repens fl. pl. A pretty, double-flowering,

bright golden yellow Buttercup; flowers
in May and June ................. $1.50 \quad 10.00 \quad 90.00$

RUDBECKIA (Coneflower).

Golden Glow. One of the most popular hardy plants. Grows six feet high, producing masses of large, double, golden

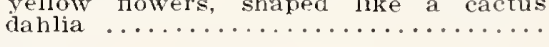

Maxima. A rare and attractive variety, growing 5 feet high, with large, glaucous green leaves and bright yellow flowers 5 to 6 inches across, with a cone
2 inches high; flowers continuously from

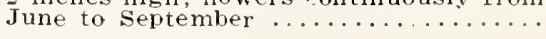

Newmanni. The perennial form of the "Black-Eyed Susan." Deep orange-yellow flowers, with a dark purple cone;

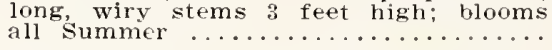

Furpurea (Giant Purple Coneflower). Peculiar reddish purple flowers, with a Blooms from July to October. 3 feet .. $1.50 \quad 10.00$

SALVIA (Meadow Sage).

Azurea. A Rocky Mountain species. Grows 3 to 4 feet high, producing, during AuHowers in the greatest profusion ......

Farinacea. Beautiful pale blue flowers..

Pitcheri. Similar to the above, but of more branching habit and large flowers of a rich gentian-blue color, and one of the most admired plants by the many visAutumn. 3 to 4 feet ................ 2.50 18.00

Pratensis. Dwarf blue flowers in June . . $1.50 \quad 10.00$ 150.00

Turkestanica. Extremely decorative sweet scented foliage and shory whorls of white flowers surrounded by pale pink. 2.00 $\quad 2.00 \quad 125.00$

Virgata nemorosa. Distinet and effective foliage with showy whorls of white

flowers $\ldots \ldots \ldots \ldots \ldots \ldots \ldots \ldots \ldots \ldots \ldots . \ldots \ldots 1.50 \quad 10.00$

90.00

SANTOLINA (Lavender Cotton; Ground Cypress). A sweet smelling, dwarf, evergreen perennial, with delicate, ly used in carpet bedding.

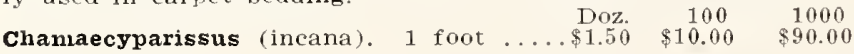

\section{SANGUINARIA.}

Canadensis (Bloodroot). Native. A low perennial, about 6 inches high, with pure white flowers an inch in diameter, in early spring. The large, leathery leaves appear later. Plant in rich, shady
places or rock garden .............. $1.50 \quad 10.00$

SAPONARIA (Soapwort).

Ocymoides alba. A grand pure white-

flowering plant for wall or rockery . . $1.50 \quad 10.00$ 90.00

ocymoides splendens. Pretty border and

rockery plant; flowers rosy pinli..... $1.50 \quad 10.00$ 


\section{SAXIFRAGA (Megasea).}

Cordifolia. These will thrive in any kind of soil and in any position. Grow about
1 foot high, and are admirable for the front of the border or shrubbery, forning masses of handsome, broad, deep green foliage, which alone renders them useful; flowers appear very early in the

spring. Fine among rocks or ledges ..\$4.00 $\$ 30.00$

Crassifolia. 12 to 15 inches. April to June. Showy and spreading. Drooping masses of pink flowers ligh above the large,

clustered leares. A fine rock plant ...
McNabiana. 1 foot. Numerous white flow-

ers hearil

dots. The spots listoe. Mar and June.. 7.00

Michauxi (Michaux saxifraga). Alpine variety. Rare. strong, establislied

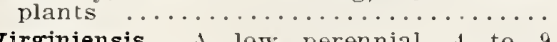

virginiensis. A low perennial, 4 to 9

white flowers apiearing in early spring.

Fine for rockeries

30.00

$00 \quad 50.00$

$3.00 \quad 20.00$

CABIOSA (Pin Cushion Flower).

Handsome border plants, succeeding in any ordinary soil if Handsome border plants, succeeding in any ord be srown in every garden where cut Howers are wanted; they last a long time when picked and placed in water.

Caucasica (Blue Bonnet). A soft Doz. $100-1000$ charming shade of larender; commences to bloom in June, throwing stems 18 to

24 inches high until September ....... \$2.00 $\$ 15.00 \quad \$ 140.00$

Caucasica alba (White Bonnet). The

Japonica. Lavender-blue flowers, from

July to September. 2 feet $\ldots \ldots \ldots \ldots$.

Pennsylvanica (Cephalaria tatarica). Large

golden rellow flowers, similar to the
true Scabiosa in form. 5 feet $\ldots . . . .1 .50 \quad 10.00 \quad \$ 0.00$

SCUTELLARIA (Skull Cap).

Baicalensis coelestina. Short, wiry stems,

clothed with clear blue Snapdragon-

$\begin{array}{llll} & & \\ \text { shaped flowers. } 1 \text { foot. June to August. } 3.00 & 20.00 & 180.00\end{array}$

SENECIO (Groundsel).

Clivorum. Forms a neat tuft of foliage,

from which spring up from July to Oc-

trom which spring up from July to oc-

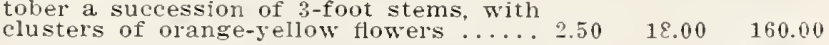

SHORTIA.

Galacifolia. A rare and beautiful species,

but recently introduced from the moun-

tains of North Carolina. The leares are

evergreen and the petals, five in number,

are pure white, and scalloped or notched

on the edges. Flowers about an inch

across in early summer. Plant in a rich,

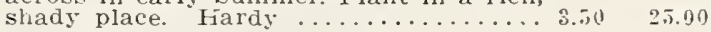

SIDALCEA (Greek Mallow).

Erect-growing, more or less branching plants, producing their showy flowers during June and July. They will succeel in any garden soil iri a sunny position.

Rosy Gem. Pretty, bright rose-colored Doz. $100 \quad 1000$ $\$ 1.50 \quad \$ 11000$

SILENE (Catchfly)

A charming class of plants for the rock garden. They are closely allied to the Pink family and require mucin the sam treatment. They bloom nearly all summer and are very desir able additions to the rockery.

Acaulis. Close cushions of foliage,

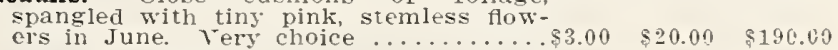

Alpestris. Dwarf rock plant, dainty, pure

white flowers in IIay and June , pure $1.50 \quad 10.00$

Saxifraga. A choice Alpine of mossy growth. Flowers white, in great profusion

$3.00 \quad 20.00$

Schafta (Autumn Catchfly). A charming border or rock plant, growing from 4 to 6 inches high, with masses of bright pink flowers from JuI to October … $1.50 \quad 10.00$

Stellata (Stairy Campion). Strong established plants

Virginica (Fire Pink) Very showy crimson

flowers. Strong established plants
$2.50 \quad 18.00$

$2.50 \quad 18.00$

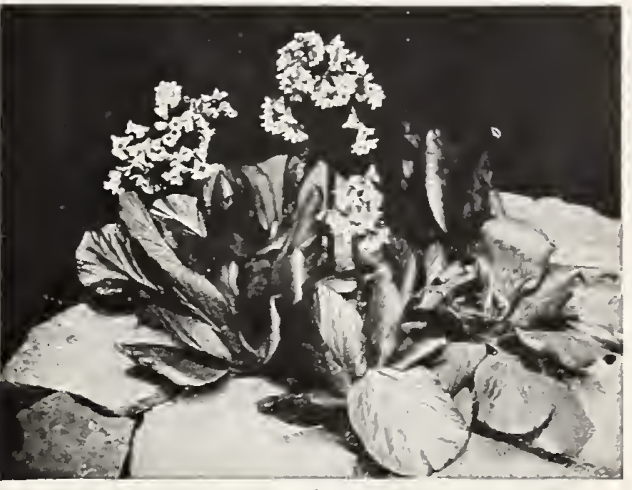

Saxifraga.

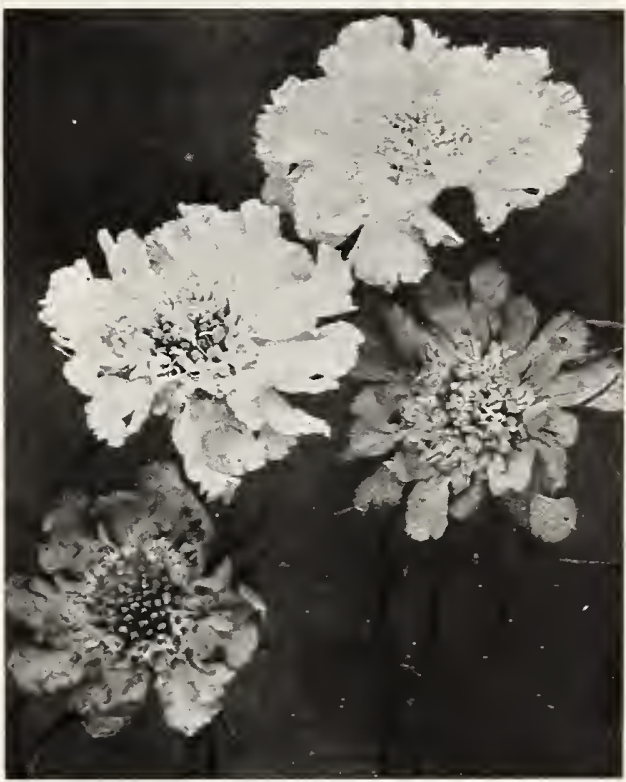

Scabiosa Caucasica.

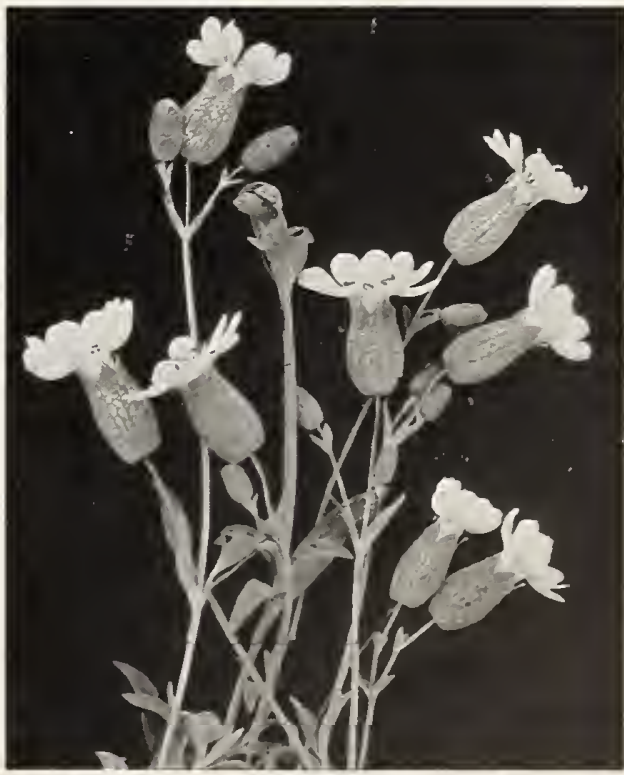

Silene. 


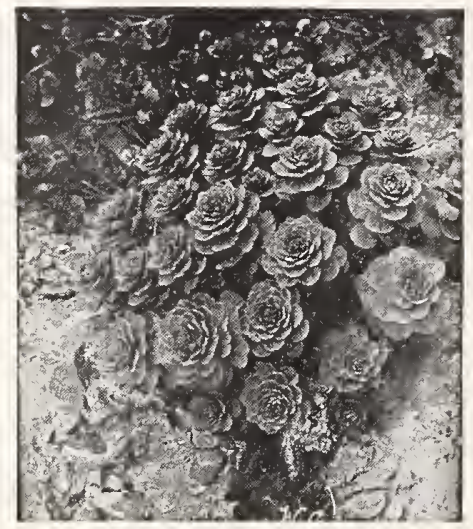

Sedum Spuriam Coccineum.

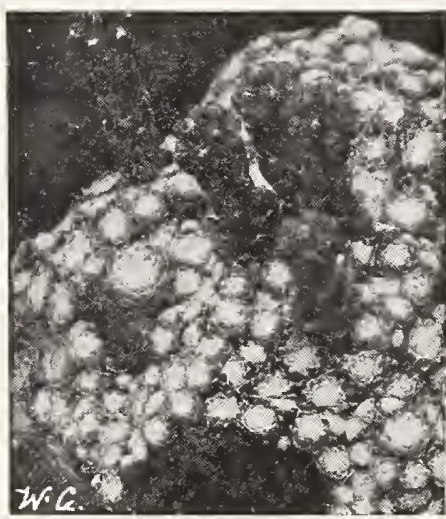

Sempervivum.



Sedum Spectabile.

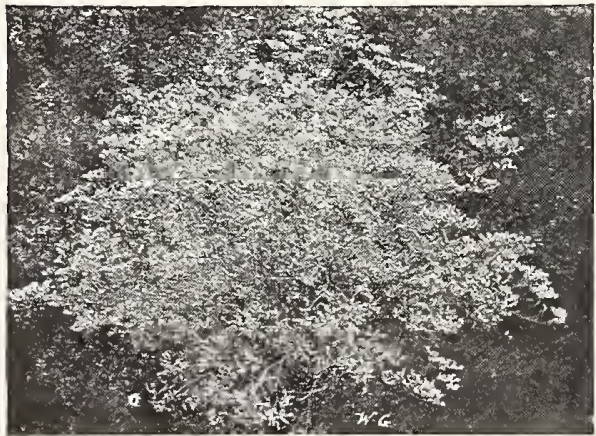

Statice Latifolia.

\section{SEDUM (Stonecrop)}

The dwarf varieties are charming plants for sunny positions in the rockery etc, and the taller kinds make effective color groups in the border. They thrive in almost any soil. They are especially fond of sand and full sun and may be considered the backbone of the American rock gailen.

\section{DWARE VARIETIES}

Aizoon. Bright yellow flowers. 1 foot. Doz. $100 \quad 1000$

July and August $\ldots \ldots \ldots \ldots \ldots \ldots \ldots \ldots \$ 1.50 \quad \$ 10.00 \quad \$ 90.00$

Acre (Golden Mloss) Much used for cov-

ering graves; foliage green; flowers 125 8.00 70.00

Ewersi. Rose-colored fiowers, with o

cous gray foliage: sub-trailing habit $1.50-10.00 \quad 90.00$

Glaucum. Excellent dwarf variety for

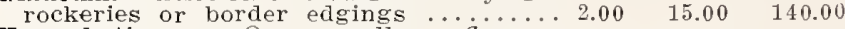

Kamschaticum. Orange-yellow "fowers, with prostrate, green foliage, turning

golden in Autumn ................... $3.00 \quad 20.00$

Kamschaticum fol. var. Similar to above,

but has attractive, variegated foliage. $4.00 \quad 30.00$

Obtusatum. Golden yellow flowers, with

emerald-green foliage, shaded bronze.

3 inches ......................... $3.00 \quad 20.00$

Fruniatum Fursterianum. Pretty, glau-

cous, bluish green leaves, of trailing

Sarmentosum. Excellent dwarf variety for rockeries or border edgings. The best Sedum for flling seams between rocks in wall garden; rapid grower .... 1.75

sexangulare. Very dark green foliage;

sieboldi. Round, succulent, glaucous foliage; bright pink flowers in August and September $\ldots \ldots \ldots \ldots \ldots \ldots \ldots \ldots \ldots$ beautiful

purium coccinem.

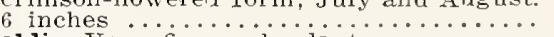

Stahli. Very fine rock plant $\ldots \ldots$
Stolonifera. flat. Succulent leaves; flowers purplish

Ternatum. Excellent dwarf variety for rockeries or border edgings ......... 1.25

\section{ERECT-GROWING VARIFTIES}

Useful and pretty plants for the border, producing their interesting flowers during late summer and Fall.

spectabile. One of the prectiest erectgrowing species, attaining a height of and immense heads of handsome. showy, rose-colored flowers; indispensable as a

late Fall-blooming plant ........\$ \$1.25 \$\$.00

Spectabile "Brilliant." A rich colored form of the preceding, being a bright amaranth-red ............................

SEMPERVIVUM (House Leek).

Curious and interesting plants forming rosettes of succulent leaves of rarying colors. Good for rockeries, dry banks, carpet bedding or walls.

Arachnoideum (Cobweb House Ieek). Leaves in rosettes usually connected by silvery threads. Flowers bright red. ${ }^{6}$

Atrcviolaceum. Large rosettes of a deep

Browni. Gravish green rosettes ....... 3.00 Fauconetti. Deep green, very compact...
Funcki. Light green rosettes, with heary Funcki. Light green rosettes, with heary Hooteri. Grayish green leaves in flat

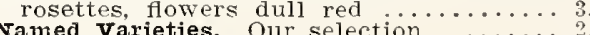

TATICE (Great Sea Lavender)

Iatifolia. A valuable plant either for the border or rockerv, with tufts of leathery leaves and immense candelabra-like heads, frequently $11 / 2$ feet high and feet across, of purplish blue, minute flowers during July and August. These, if cut and dried, last in perfect condi-

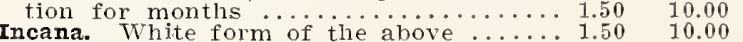

STENANTHIUM (Mountain Feather Fleece).

Robustum. A rare perennial, with showy panicles of pure white, fleecy flowers in August and September on stems 4 to 5 feet high; requires a moist, semi-shady position
$00 \$ 180.00$

$20.00 \quad 180.00$

$20.00 \quad 180.00$

180.0

$20.00 \quad 180.00$

$20.00 \quad 180.00$ 165.00
15.00

2.00 


\section{SPIREA - Astilbe}

(Arendsi and Japonica Hybrids).

Hybrid varieties of very vigorous growth, producing manybranched, feathered heads of flowers in June and July They prefer a half-shady, moist position in any ordinary garden soil. mediate effect.

Doz. $\quad 100 \quad 1000$

America. Deep pink; excellent forcing ra- $\$ 3.50 \quad \$ 25.00 \quad \$ 225.00$

Betsy Cuperius Splendid new

orowin 5 feet

srowing 5 feet high. The fine drooping

flower spikes 2 feet long, show in sum-
mer during some weeks a great number

of white flowers with pink center $\ldots$

Brunhilde. A great improvement on the variety Venus; the thick flower spikes
are crowded with clear lilac flowers

ceres. Growing $21 / 2$ to 3 feet high, with spikes of a rosy lilac color; fine garden

Deutschland. 'Dwarf habit, and producing

dense, feathery plumes of a splendid

brilliant dark-pink color with a soft
lilac shade ................... 5.00

Embcen. Compact plumes; fiowers of a 5.00

Freule Van Den Bosch. New variety, grow-

Freule Van Den Bosch. New variety, grow-
ing about $31 / 2$ feet high. Produces coming about $31 / 2$ feet high. Produces com-
pact flower spikes of a dark pink color.

Splendid novelty for the garden . . . . 10.0
Gladstone. 18 inches. June-July. A fine

Gladstone. 18 inches. June-July. A fine
variety. Immense trusses of flowers are as white as snow, borne on erect,

strong stocks; best white for forcing.

Grandis rosea maxima. The drooping spikes of flowers have a length of over 2 feet,

and are a beautiful creamy white, with

pink centers. 5 to 6 feet $\ldots . . . \ldots \ldots . . . .$.

high and produces light and graceful spikes of spreading habit and has a spikes of spreading habit and has a
splendid salmon-pink color. Award of splendid salmon-pink color. Award of
Merit R. H. S. of Holland .............

Marquerite Van Rechteren. This plant grows about 5 feet high. The flower stem itself has a length of over 3 feet. The very fine fringed flowers are bright red tinged with dark lilac ............

dense flower spikes of a delightful pink

color. Very recommendable. Award of

IIerit $R$. H. S. of Holland .............

Mowe. Striking novelty with long, weil formed spikes and splendid crimson

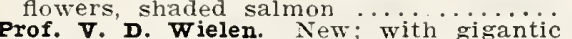

Prof. V. D. Wielen. New; with gigantic
long stems and side stems, showing fine long stems and side stems, showing fine
small, pure white fowers in profusion. 7.00

Queen Alexandra. Light pink; good for

forcing Rhineland. The compact spikes are bright

crimson colored with salmon shade ...

Rubens. Rosy red; new and good; fine for

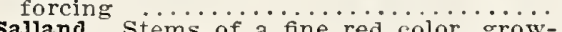

inana. Stems of a fine red color, grownovelty. Award of Merit R. H. S. of novelty. Award of Merit $R$. H. $S$. of

Hesta. New. Tail ilac-rose spikes; beau-

tiful garden variety .............. 8.00

$30.00 \quad 275.00$

$.00 \quad 30.00 \quad 275.00$

$.00 \quad 30.00 \quad 275.00$

$.00-30.00$

275.00

$30.00 \quad 275.00$

$0.00 \quad 80.00$

$25.50 \quad 25.00 \quad 225.00$

$5.00 \quad 30.00 \quad 275.00$

$5.00 \quad 30.00 \quad 275.00$

$5.00 \quad 30.00 \quad 275.00$

$5.00 \quad 30.00 \quad 275.00$

$5.00 \quad 30.00 \quad 275.00$

$50.00 \quad 475.00$

$25.00 \quad 225.00$

$30.00 \quad 275.00$

$25.00 \quad 225.00$

$50.00 \quad 475.00$

$60.00 \quad 575.00$

SPIREA (Goat's Beard; Meadow Sweet).

Elegant border plants with feathery plumes of flowers and

neat, attractive foliage; succeeds in all locations.
Doz.

Aruncus. 4 feet. June. Produces long, feathery panicles of white flowers, form-

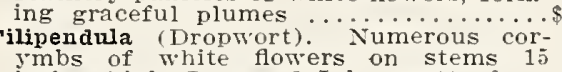
inches high. June and July; pretty fern-

rilipendula flore pleno. iz to 18 inches.

June and July. Double white flowers

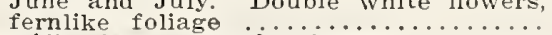
Kneiff. Very graceful foliage, finely cut
into hairlike segments, with large,
cream-colored flower spikes...........

Palnata elegans. 3 feet. June to August. Graceful plumes of lovely light pink flowers. Fine for waterside planting "Meadow sweet." Creamy white flow-

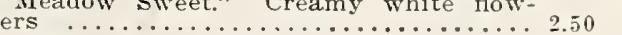

100

$\$ 35.00 \$ 300.00$

$1.50 \quad 10.00$

80.00

$3.00 \quad 20.00$

180.00

$8.00 \quad 70.00$

$3.00 \quad 20.00$

$2.50 \quad 15.00$

STACHYS (Woundwort).

Ianata. Fine old-fashioned cottage garden plant for edging; useful in rock garden; dwarf; soft silvery foliage;

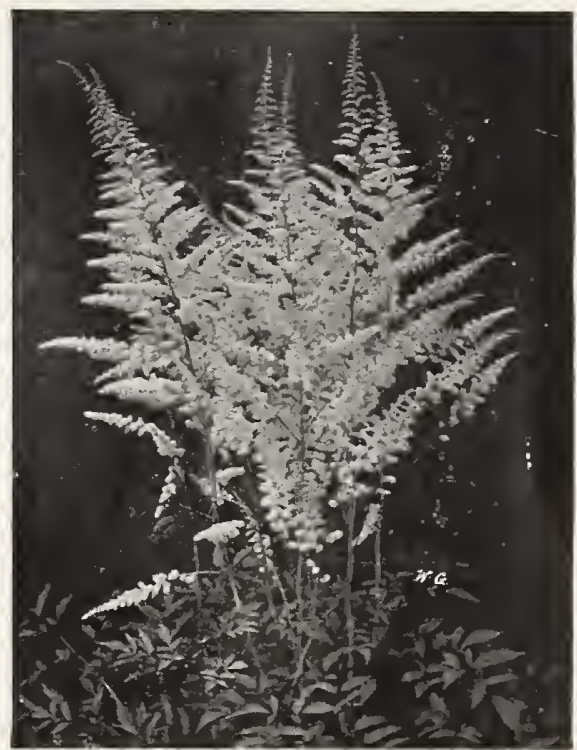

Spirea Gladstone.

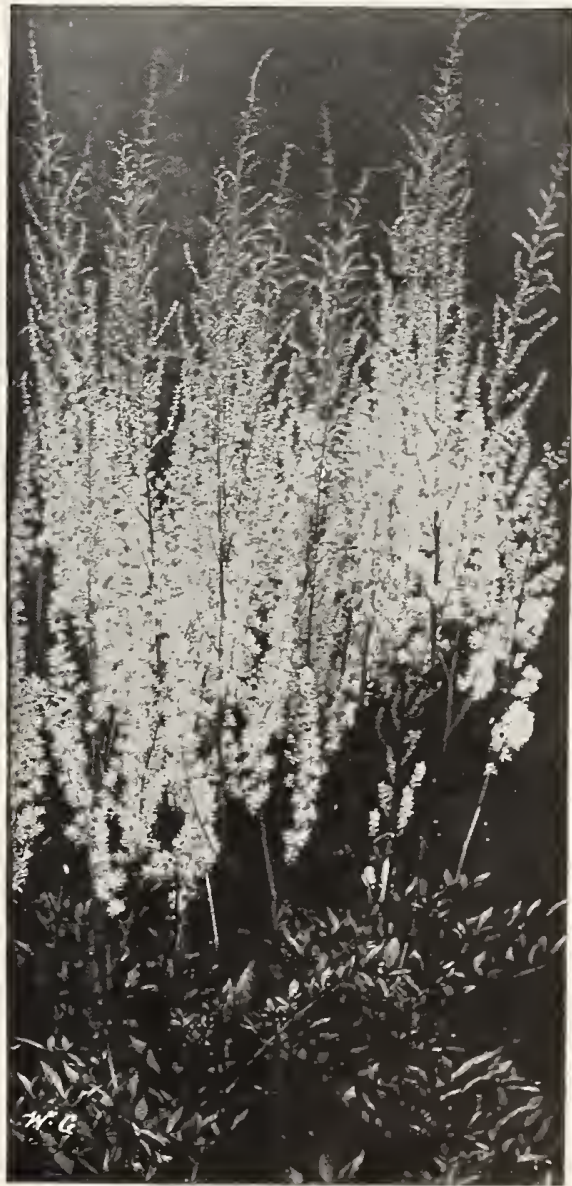

Astilbe Arendsi Hybrid, Grandis Rosea Maxima.

No garden is complete without these new and easily grown Arendsi Hybrid Astilbe. We will be glad to make you up a collection of the best. 


\section{$\begin{array}{lllllllllllllllllllllllllllllll}T & H & E & I V & A & Y & S & I & D & E & G & A & R & D & E & N & S & C & O & \end{array}$}

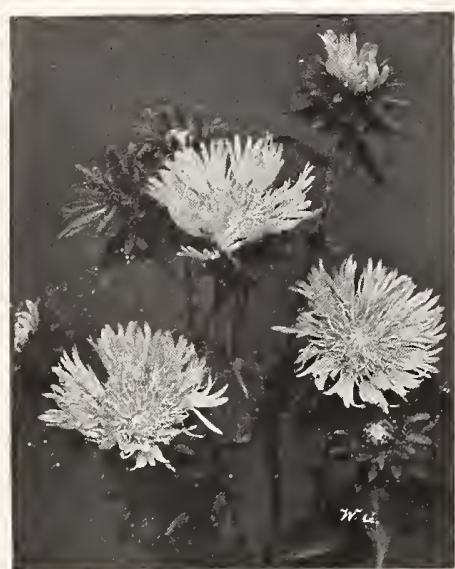

Stokesia Cyanea.

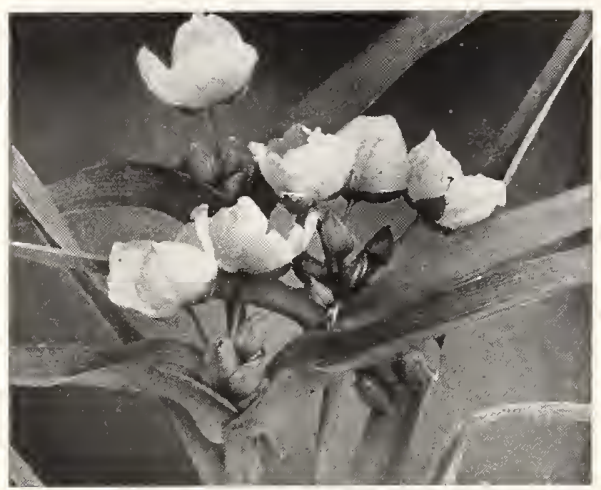

Tradescantia Virginiana.

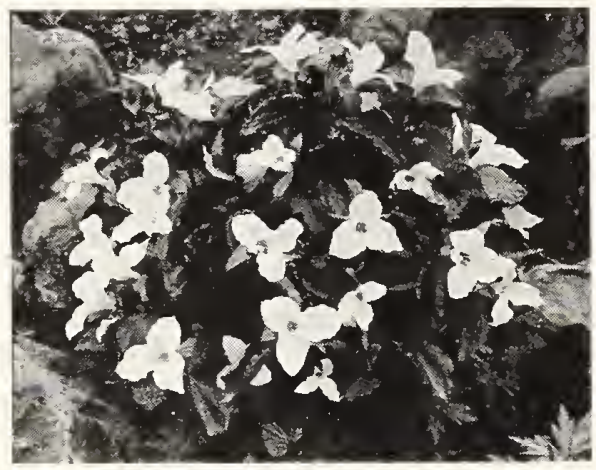

Tríllium Grandiflorum.

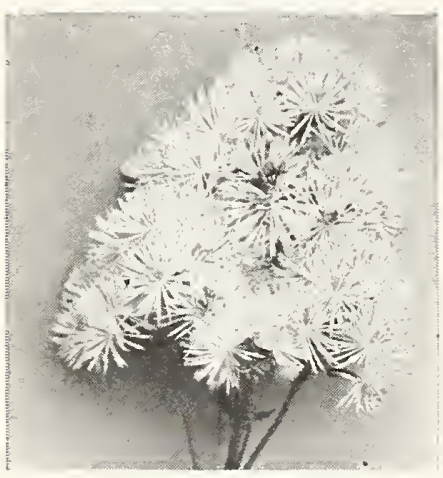

Thalictrum Aguilegifolium.
STOKESIA (Cornflower Aster; Stokes' Aster).

A most charming and beautiful native hardy plant which, for A most charming and beautiful native hardy plant which, for many seasons, has been the most admired flower on our freely from early July until late in October its handsome freely from early July until late in October, its handsome lavender-blue centaurea-like blossoms, which measure from 4
to 5 inches across. It is of the easiest culture, succeeding in to 5 inches across. It is of the easiest culture, succeeding in
any open, sunny position, desirable as a single plant in the hav' border and effective in masses or beds of any size.

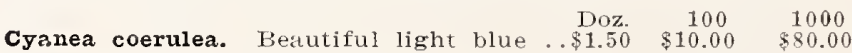

Cyanea coerulea alba. White-fiowered form

of the above. 1 to $1 \frac{1 / 2}{2}$ feet $\ldots \ldots \ldots \ldots .2 .00 \quad 15.00 \quad 125.00$

SWEET WILLIAM (See Dianthus Barbatus).

TEUCRIUM (Germander).

Chamaedrys. Shrublike habit. Fxcellent

plant. Glossy green foliage, purpie flow-

er spikes in July and August. 1 foot . $3.50 \quad 25.00 \quad 200.00$

THYMUS (Thyme).

The charming Mountain Thymes make a perfect, close, fragrant carpet on hot, dry, sunny banks where grass is difficult to establish they are a sheet of blossom in June and July. Excellent for carpeting patches of Spring-flowering bulbs.

Doz. $\quad 100$

1000

Album. A wonderful contrast with Coc-
cineum; flowers a sheet of white . . . \$3.50 \$25.00

cineum; flowers a sheet of white ..... $\$ 3.50 \quad \$ 25.00$
Citriodorus. The golden yellow form of
the well known "Lemon Thyme"

Coccineum. Plants become completely cov-

ered with brilliant crimson-scallet flow-

Lanuginosus (Woolly-Leaved). Woolly foliage with bright pink flowers ..... $3.00 \quad 20.00$

serpyllum (White Mountain Tlyme) Forms dense mats of dark green foli-

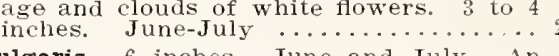

vulgaris. 6 inches. June and July. An old garden plant, being grown as a sweet herb; flowers small, lilac or purplish, in terminal, interrupted spikes; foliage $\begin{array}{llll}\text { very fragrant. Fine for rock garden.2.00 } & 15.00 & 140.00\end{array}$

TIARELLA (Miterwort).

Cordifolia. 6 to 12 inches. May. An elegant plant with fine foliage and small, fers partial shade .................. $1.50 \quad 10.00$

TRADESCANTIA (Spiderwort).

virginiana. Produces a succession of blue

Howers all summer. 2 feet ........... 1 .

virginiana alba. A white-flowered form:

TRILLIUM (Wood Lily or Wake Robin).

Grandiflorum. Excellent plants for shady

positions in the hardy border, or in a

sub-aquatic position. Large, pure white

flowers in early Spring. 12 to 18 inches. 1.25

8.00

70.00

THERMOPSIS (False Lupine; Buffalo).

Caroliniana. A showy, tall-growing plant, attaining a height of 3 to 4 feet, pro-

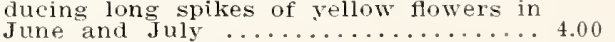

THALICTRUM (Meadow Rue).

Adiantifolium. A beautiful rariety, with foliage like the Maidenhair Feris and miniature white flowers in June .......

Aquilegifolium. Graceful foliage like that

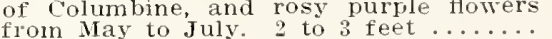
Aquilegifolium album. White form of the above

Dipterocarpum. A pretty and distinct species, with flowers of a charming shade of lilac-mauve, which is brightened by a bunch of lemon-rellow stamens and anthers. The plant is of mens and anthers. The plant is of strong growth, about 4 feet high. The dainty fowels are produced in graceful
sprays during August and september.. $2.00 \quad 15.00 \quad 125.00$

Minus. Dwarf, with Maidenhair fernlike foliage $\ldots \ldots \ldots \ldots \ldots \ldots \ldots \ldots \ldots \ldots \ldots \ldots \ldots 2.00 \quad 15.00 \quad 125.00$
$2.00 \quad 15.00 \quad 125.00$

DIPTEROCARPUM IS AN EXTRA FINE CUT FIOWER
$20.00 \quad 180.00$ 


\section{$\begin{array}{llllllllllllllllllllllllllllll}H & A & R & D & Y & H & E & R & B & A & C & E & O & U & S & A & N & D & A & L & P & I & N & E & P & L & A & N & T & S\end{array}$}

TRITOMA (Red Hot Poker; Flame Flower; Torch Lily).

Pfitzeri (The Everblooming Flame Flower). The free and continuous blooming qualities of this variety have made it one of the great bedding plants, and when we consider that there are few flowering plants which are suitable for massing under our severe climatic conditions it is little wonder that such an elegant subject shouid become so popular. Succeeds in any ordinary garden ular. Succeeds in any ordinary garden soll, but responds quickly to liberal treatment. Hardy if given protection, wintering is to bury the roots in sand in a cool cellar In bloom from August to actober, with spikes 3 to 4 feet high, to October, with spikes 3 to 4 feet high, and heads of bloom of a rich orangeplanted singly in the border or in masses .....................\$3.00 \$20.00 \$180.00

Perxy's Unnamed Hybrias. These are seedlings of various colors, ranging from pale yellow to deep orange and ar very showy in a hardy plant border.. $3.00 \quad 20.00 \quad 180.00$

Quartiniana. A strong growing, thickstalked variety, blooming late in May
with flower cones 10 to 12 inches long. with flower cones 10 to 12 inches long. Orange-red at first, but yellow on bothardy here; does not need protection . $3.00 \quad 20.00 \quad 180.00$

Uvaria grandiflora. 3 to 4 feet. The oldfashioned, late-flowering sort, with flowers rich red changing to salmon-pink. Needs slight protection $\ldots \ldots \ldots \ldots \ldots \ldots .3 .00 \quad 20.00 \quad 180.00$

TROLLIUS (Globe Flower).

Europaeus, Orange Globe. Desirable freeflowering plants, producing their giant bright yellow, buttercup-like blossoms on stems 1 to 2 feet high from May until August: succeeds admirably in the border in a half-shady position $\ldots \ldots \ldots \ldots 4.50 \quad 35.00 \quad 325.00$

Choice seedings. Colors range from pale yellow to deep orange: on strong stems 2 feet high. Wonderful as cut flowers, and good in moist locations ......... 4.00

TUNICA (Coat Flower).

Saxifraga. A pretty tufted plant with light pink flowers, produced all Summer. Useful either for the rockery or

the border $\ldots \ldots \ldots \ldots \ldots \ldots \ldots \ldots \ldots \ldots \ldots 1.50 \quad 10.00$

90.00

VALERIANA (Valerian; Garden Heliotrope).

Coccinea. Showy heads of old rose flowers. June to October. 2 feet ....... 1.50

10.00

80.00

offinalis (Hardy Garden Heliotrope). Produces showy heads of rose-tinted white flowers during June and July with delicious, strong heliotrope odor.

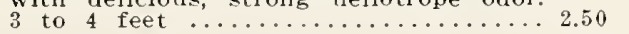

15.00

\section{VERATRUM.}

viride (American White Hellebore). Native. Thrifty plants, large, broad, green leaves, nearly a foot long. Grows 2 to 4 feet high, bearing many small, yellow, or greenish Howers at top. At home in a moist or wet, black peaty soil $\ldots \ldots \ldots 3.00 \quad 20.00 \quad 180.00$

VERBASCUM (Mullein).

Olympicum (Greek Mullein). The showlympicum (hreek muly of more than iest of the entire family of more than thirty rarieties. The foliage is silvery white, with leares often 3 feet long. The flowers are yellow, and are produced in summer. Succeeds best in a dry situa-

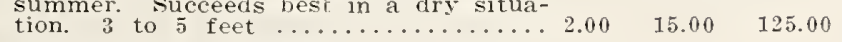

Wayside Gardens Fybrids. An excellent strain produced from a very superior
grade of Englisl Hybrids. Colors are most interesting

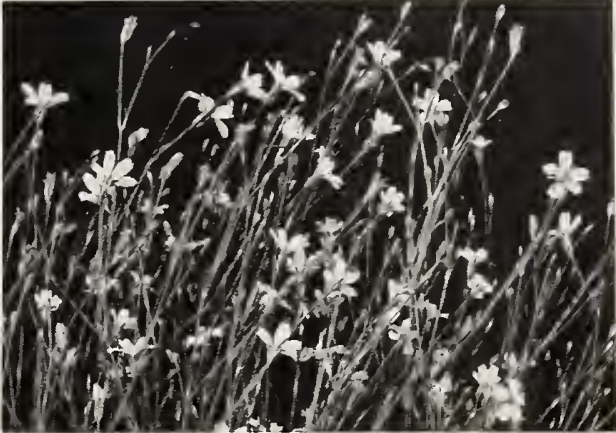

Tunica Saxif raga.

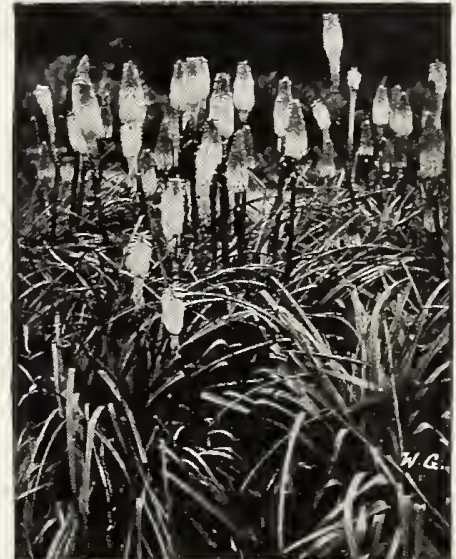

Pfitzer's Tritoma

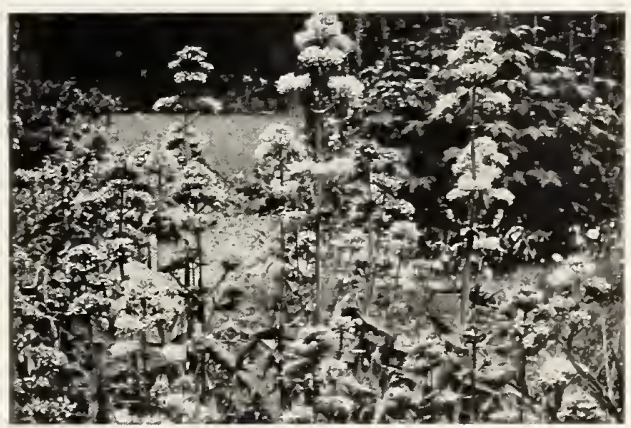

Valeriana Coccinea.

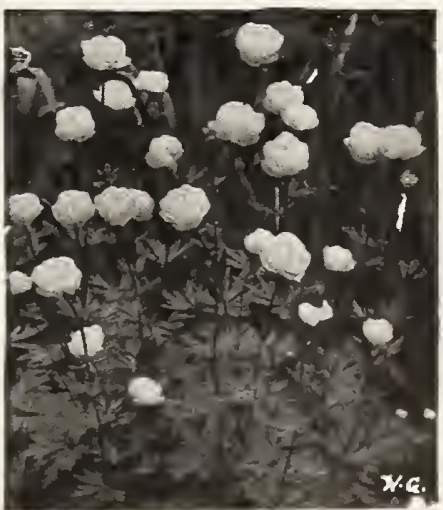

Trollius, Orange Globe 


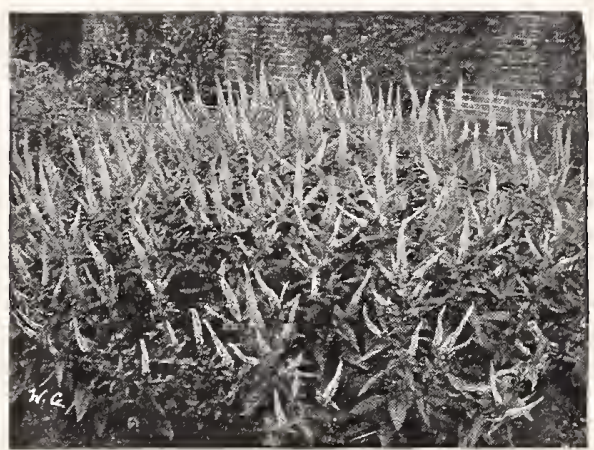

Veronica Erica.

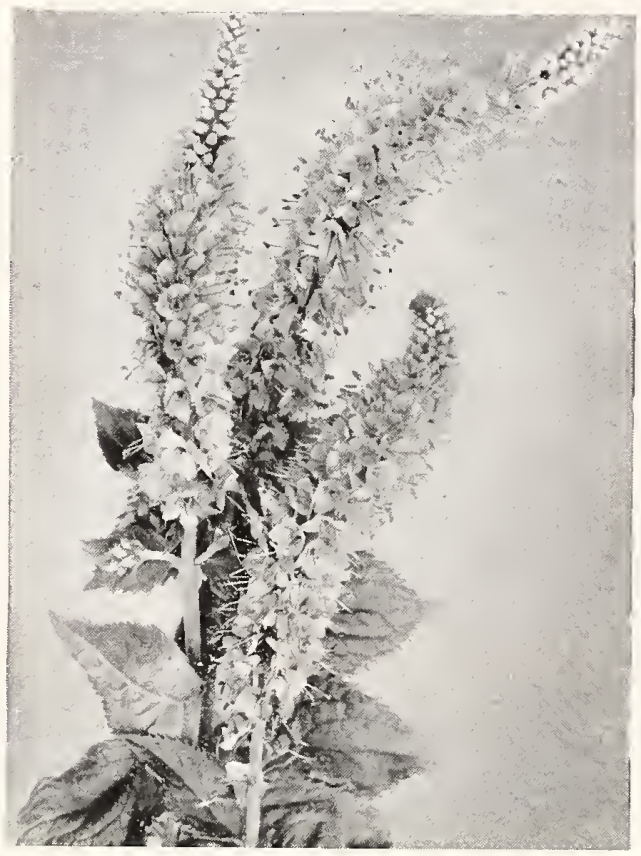

Veronica Longifolia Subsessilis.

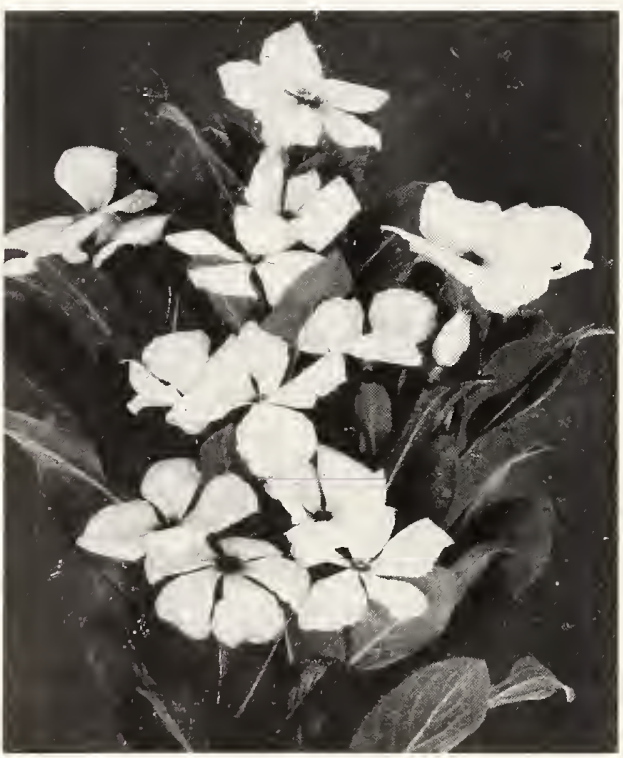

Vinca.

\section{VERONICA (Speedwell).}

A family containing some of the most beautiful subjects for the hardy garden and rockery. Given a rich, well drained soil in an open situation in full sun, they will all thrive in an amazing manner.

Amethystina. 8 to 12 inches. June. A Doz $100 \quad 1000$

slender species, with short spikes of

amethyst-blue flowers $\ldots \ldots \ldots \ldots \ldots \ldots \ldots \$ 2.50 \quad \$ 18.00 \quad \$ 170.00$

Amethystina "Royal Blue." Beautiful

spikes of rich gentian-blue flowers. 1

foot. June and July ................. $3.00 \quad 20.00 \quad 190.00$

Erica. A heather-like speedwell with deli-

cate pink flowers. June-July ...... 2.50 $18.00 \quad 170.00$

Gentianoides. Beautiful variety with spikes of large flowers, palest blue edged deep blue, in June and July. 1 foot $\ldots \begin{array}{llll}3.00 & 20.00 & 190.00\end{array}$

Incana (candida). 1 foot. July and August. A white, woolly plant; flowers numerous; blue. Has good appearance, both in and out of bloom. Useful in rockery or

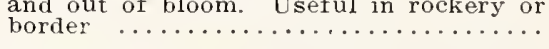

Iongifolia subsessilis. 2 feet. July to September. One of the handsomest blue-
flowering plants. Perfectly hardy and increases in strength and beauty each year. Spikes completely studded with beautiful blue flowers; fine for cutting and one of the best plants for the hardy bordel

Repens. 3 to 4 inches. May and June. A useful rock or carpeting plant with light blue flowers .................... $1.50 \quad 10.00$

Rupestris. A fine rock plant growing 3 to 4 inches high; thickly matted, deep green foliage, hidden in Spring under a cloud of bright blue flowers ..........

Iupestris rosea. Similar to the above in habit and growth. The flowers form a carpet of bright rose; good foliage...3.00

Spicata. 18 inches. June and July. Long spikes of violet-blue flowers .......... $1.50 \quad 10.00$

spicata alba. Long spikes of snowy white flowers $\ldots \ldots \ldots \ldots \ldots \ldots \ldots \ldots \ldots \ldots \ldots . \ldots 1.50 \quad 10.00$

spicata rosea. 2 feet. June to September.

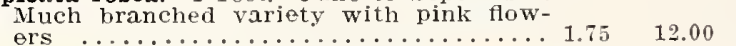

Teucrium. Dwarf; spreading, of a dense growth; Howers blue. 6 to 12 inches.

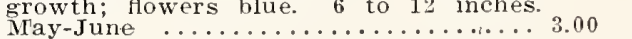

Traversi. A very hardy variety of the beautiful shrubby Veronicas flom New Zealand. Forms compact bushes of dark green foliage, bearing a profusion of pale

rue Blue Literally covers itself with

True Blue. Literally covers itself with
blossoms of intense blue. I foot ..... 3.00 blossoms of intense blue. I foot ......

Virginica (Great Virginian speedwell). A free-growing perennial which likes the $\begin{array}{lllll}\text { blue. } 2 \text { to } 6 \text { feet. August to September. } & 1.75 & 12.00 & 100.00\end{array}$

VINCA (Periwinkle or Trailing Myrtle).

Minor. A trailing, evergreen plant, used extensively for carpeting the ground under shrubs or trees or on graves, where it is too shady for grass or other plants to thrive ....................... $1.50 \quad 10.00$

3-inch pot plants of Vinca Minor may be obtained any time of the year. They are potted plants with about 8 to 12

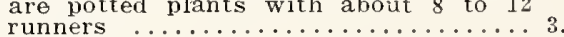




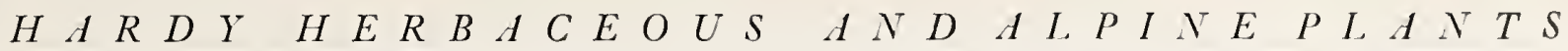

\section{VIOLA.}

\section{VIOIA CORNUTA (Tufted Pansies).}

This is the best edging plant for the hardy border or garden; when properly cared for, these plants remain in full bloom from lay until October. The great secret of their continuous bloom, though, is the fact that they must be sheared several times during the season, so that the flowers do not go to seed. Admiration. Dark blue .......... Doz. $\$ 1.25 \quad \$ 8.00 \quad \$ 60.00$ Floraire. A gem, having the growth of the bedding Viola and producing profusely, all Summer through, large blosin and around Ge. This tiola is and and is a product of the well known Mon-

sieur Correvon th . . . . . .

Golden Xellow ................ $8.25 \quad 8.00 \quad 60.00$ Perfection. Light blue ............ $1.25 \quad \$ .00 \quad 60.00$

Rose Queen ................... $1.25 \quad 8.00 \quad 60.00$

White Perfection .................... $1.25 \quad 8.00 \quad 60.00$

Mixed. Many shades and markings .... $1.25 \quad 8.00 \quad 60.00$

\section{VIOLA ODORATA (Sweet Violet).}

The variety listed below is suited for forcing under glass; and perfectly hardy, and is covered with flowers in early spring and woliderfully sweet scented.

Gov. Herrick. Rich, deep purple $\ldots \ldots \ldots \ldots \begin{array}{ccc}\text { Doz. } & 100 & 1000 \\ \$ 2.00 & \$ 15.00 & \$ 125.00\end{array}$ VIOIA HYBRIDS AND SPECIES (Everblooming).

$\begin{array}{lllll}\text { Blanda. Sweet scented white Violet } \ldots .2 .00 & 15.00 & 140.00\end{array}$ Bosniacea. A superb, everblooming Pansy, makes neat clumps that are covered with redish violet nowers throughout the duction .......................... $2.00 \quad 15.00-140.00$

G. Wermig. A variety of Tufted Pansy, forming clumps which are covered with rich, violet-blue fowers the entire sea-

son Jersey Gem (New). Possesses the dwarf habit and continuity of blooming of the vigorous, bushy growth and roundish foliage of the finest English bedding vafoliage of the finest English bedding va-
rieties. Color is pure, rich violet, and slightly perfumed ................ 4.00 30.00

WALLFLOWER.

The old fragrant favorite; mixed colors:

choice English imported strain including

$\begin{array}{llll}\text { choice English imported strain including } & & & \\ \text { yellow, brown, etc. Plant in Spring only. 1.25 } & \$ .00 & 70.00\end{array}$

YUCCA (Adam's Needle).

Filamentosa. Among hardy plants there is nothing more effective and striking for isolated positions on the lawn or on dry banks where few other plants thrive. It is also indispensable for the
rockery. Its broad, swordlike, evergreen foliage and immense branching spikes of drooping, creamy white flowers, rising to a height of 6 feet, render it a placed. Should be planted in spring.

3-gear-old plants .................. 2.00 $15.00 \quad 125.00$

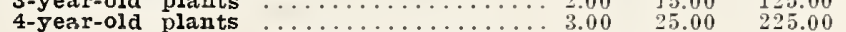

\section{HERBS}

The plants offered below are all strong roots, and will make an abundant growth the first season.

Price, except where noted, \$2.00 per 12; \$15.00 per 100 . ASPARAGUS ROOTS-Colossal and Palmetto. 2-year, \$1.50 per 100; \$10.00 per 1000. 3-year, \$2.50 per 100; \$15.00 per 1000 BAIM (Melissa officinalis). For culinary purposes.

CHAMOMILE (Anthemis nobilis), Has medicinal qualities. CHIVIS. For flavoring.

HOP ROOTS (Humulus lupulus).

HOREFOUND (Marrubium vulgare). Has medicinal qualities. HORSERADISH ROOTS. L'sed for sauces, 50c per 10; $\$ 4.00$ per 100.

IAVENDER, True (I,avandula offinalis). For oil and distilled

IMARJORAI, Pot (Origanum onites). T'sed in seasoning.

RHUBARB ROOTS-Iinnaeus and st. Martins.

ROSEMARY (Rosmarinus officinalis). Tields aromatic oil and ROSEM

RUE (Ruta graveolens). Said to have medicinal qualities.

SAGE, Common (Salvia ofticinalis). A culinary herb, also used SAVORY, Winter (Satureia montana). Used as a culinary herb. TANSY HERB (Tanecetun vulgare)

THYME (Thymus vulgaris) ['sed in seasoning.

WOODRUTF (Asperula odorata). Csed in flavoring wine

WORMWOOD (Artemisia absinthium). Has medicinal qualities.

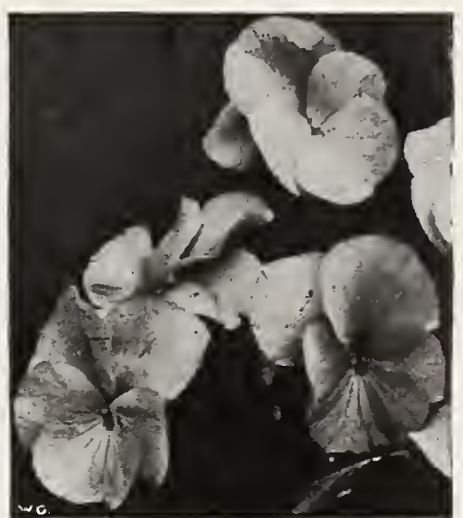

Viola Cornuta.

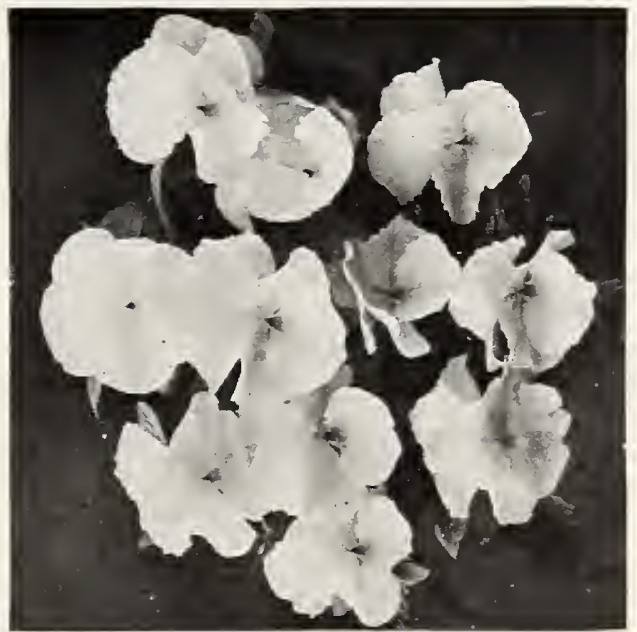

Viola, G. Wermig.

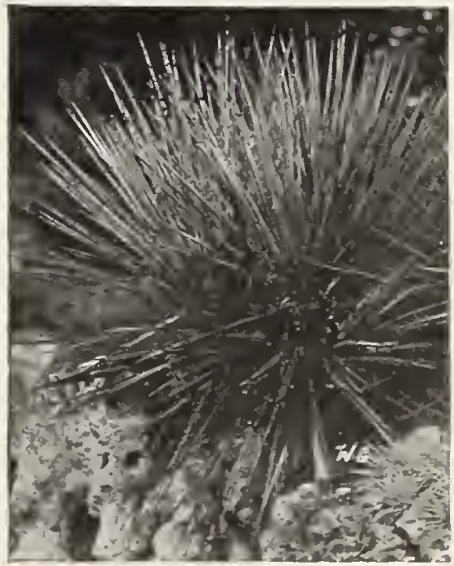

Yucca Filamentosa. 


\section{$T H E \quad W A Y S I D E \quad G A R D E N S, M E N T O R$
Climbing Plants and Vines}

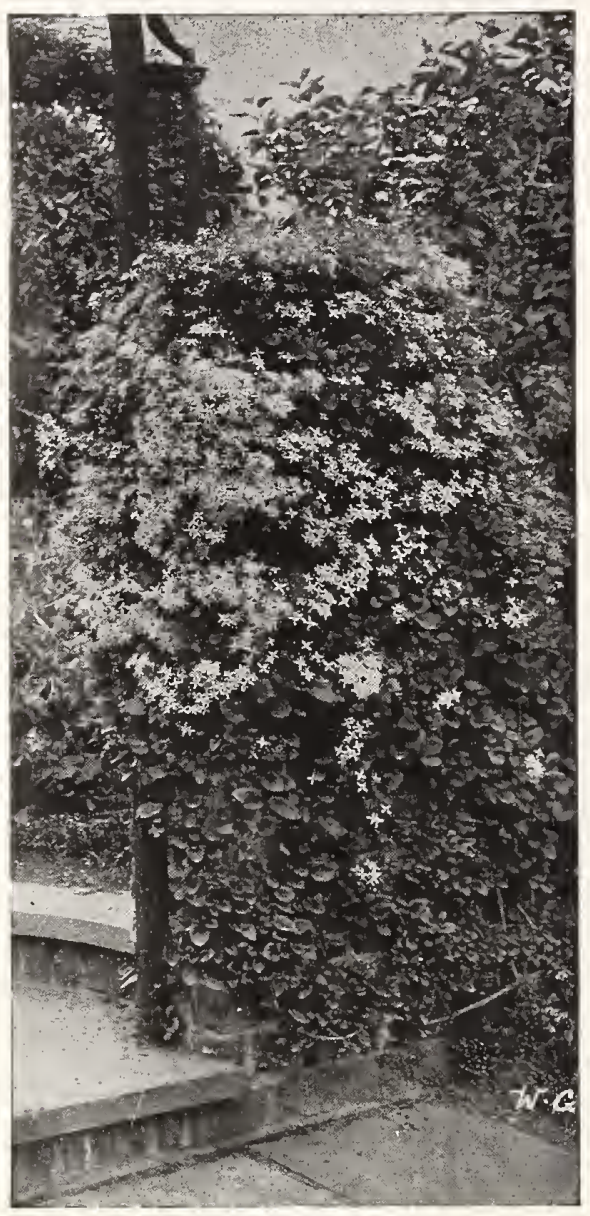

Clematis Paniculata.

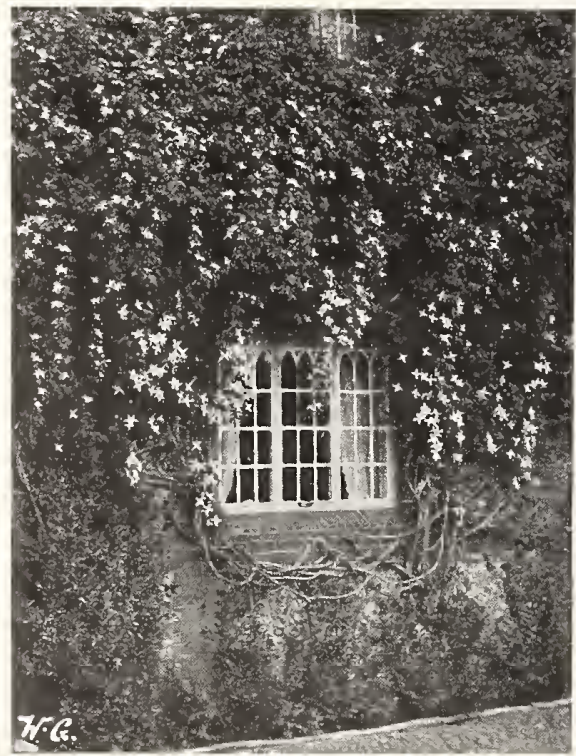

Clematis Montana.

\section{AMPELOPSIS (Ivy).}

Lowi. A splendid variation from the popular Boston or Japan IVy, possessing all the merits of the parent, being persurface without support, and with much smaller foliage, which is deeply cut, giving it a grace and elegance entirely giving it a grace and elegance entirely
distinet from the old type ...........

Veitchi (Boston Ivy or Japan Ivy). The most popular climbing plant for covering brick walls, stone or wooden walls, trees, etc. When it becomes established it is of very rapid growth, and clings to the smoothest surface with the ten-

Extra strong, 2-year-old plants

ARISTOLOCHIA (Dutchman's Pipe).

sipho. A vigorous and rapid-growing climber. Its flowers are of little value compared to its light leaves, which are of very large size, and retain their color from early spring to late Fall. Perfectly hardy strong plants ......... 9.00 70.00

\section{BIGNONIA (Trumpet Vine).}

For covering unsightly places, stumps, rock work, or wherever a showy flowering vine is desired, the Bignonias will be found very useful. The flowers are large, attractive, and borne profusely when the plants attain a fair size.

Radicans. Dark red, orange throat; free blooming and very hardy $\ldots \ldots \ldots \ldots \ldots 3.00 \quad \$ 20.00$

CELASTRUS SCANDENS (Bittersweet, or Wax Work).

One of our native climbing plants, of Doz. $100 \quad 1000$ rapid growth, succeeding in almost any situation, sun or shade, with attractive light green foliage and yellow flowers during June, which are followed in the Autumn with bright orange fruits, which usually remain on the plant throughout the Winter .......................... $\$ 5.00 \$ 40.00$

\section{LARGE-FLOWERING CLEMATIS.}

No other climbing plant equals in attractiveness the beautiful large-flowering clematis. Their requirements are somewhat different from most other plants, and proper conditions must be given to secure satisfactory results. They need rich. deep soil, perfect drainage, abundance of water and most importan beneath the surface of the soil. with the crowns three inche

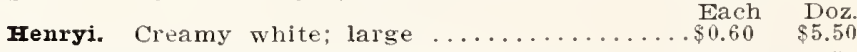
Jackmani. The popular rich purple variety .......60 $\quad .6050$ Mme. Villard. Bright carmine ..............60 5.50 Ramona, Double; pure white ..............60 5.50

CLEMATIS (Virgin's Bower).

Flammula. Very beautiful climber: white flowers; wants a sunny exposure ..... \$4.00 $\$ 30.00 \quad \$ 275.00$

Montana Perfecta (Anemone Clematis). A strong, vigorous, extremely hardy ra-
liety, thriving under most adverse conliety, thriving under most adverse con-
ditions. Its large, white flowers expand in April and May, and it is the best of

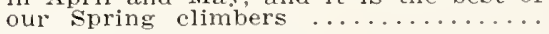

Montana rubens. Flowers rosy pink, with beautiful green foliage, shaded bronze, $4.00 \quad 30.00 \quad 275.00$

Orientalis (Tangutica or Graveolens). This is the beautiful "Golden Clematis" admired for its rich yellow flowers in and hardy vine, often flowering again

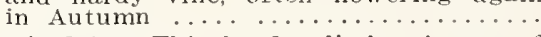

Paniculata. This hardy climber is one of the choicest and most satisfactory climbing flowering plants. Of strong,
rapid growth, with small, dense, cheerful green foliage, and pure white, deliciously fragrant flowers, in greatest profusion in August and Septiember. 3-year 


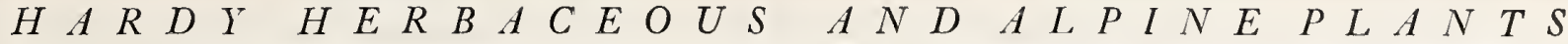

EUONYMUS (Evergreen Bittersweet).

The trailing Euonymus are particularly desirable for their dense, evergreen foliage and extreme hardiness, some varieties on account of this taking the place of the English Ivy for wall covering, others that of the boxwood as an edging plant. Makes a splendid ground cover, and one of the best creepers for rockeries.

Doz. $100 \quad 1000$

Carrieri (Carrier's Evergreen Bittersweet). A stronger grower than Euonymus Half bush and half vine in habit of growth. If given support, it makes a growth. If given support, it makes a very fine covering for a building or a wall; very rugged and a rapid grower, as it can be sheared into any shape $\ldots$, $\$ 4.00 \quad \$ 30.00 \quad \$ 280.00$ Kewensis. A variety with very small dark green foliage. Everyone who has seen this appreciates its value as a close to the ground, and is one of the most valuable plants for under trees Radicans. Deep green foliage, useful for covering low foundation walls, or may be clipped the same as boxwood for an

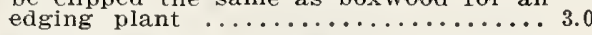

Fadicang acuta. A strong growing variety with long, narrow, dark green leaves veined with grey; excellent as a ground

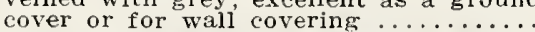

Radicans variegata. A beautiful smallleaved green and white variegated form of the same habit as the type .........

Radicans vegetus (Evergreen Bittersweet). A strong growing variety, with larger leaves than the type, and producing bright orange-red berries, which remain on the plant the greater part of the Win-
ter. As an evergreen, absolutely hardy

$\begin{array}{lllll}\text { ter. As an evergreen, absolutely hardy } & & & \\ \text { wail cover, this plant is unequalled } \ldots .00 & 5.00 & 40.00 & 390.00\end{array}$ (We can furnish heavy plants of all Euonymus from 5 to 7 years old for $\$ 1.00$ each).

\section{ENGLISH IVY (Hedera).}

The famous English Ivy with its familiar evergreen, glossy foliage is unfortunately not very hardy in this climate, and requires Winter protection where it is exposed to chilly winds on open walls. It can, however, be planted with perfect safety as a ground cover or as an edging to flover beds.

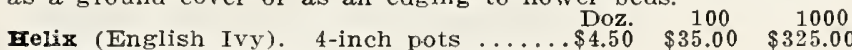

Helix gracilis. Identical in habit with the

English Ivy, but with dark green foliage

not one-half as large, a most graceful

LONICERA (Honeysuckle).

Their vining qualities are all that can be desired, but the fragrance of their flowers makes their strongest bid for favor. Halliana. Color an intermingling of

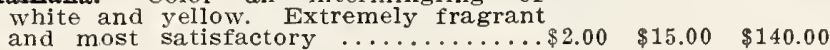

POLYGONUM (Silver Lace Vine).

Auberti. A splendid hardy climber, of strong, vigorous growth, attaining a height of 25 or more feet, producing during Summer and Fall great foamy sprays of white flowers, and a well established plant during its long period of flowering is a great mass of bloom. $5.00 \quad 40.00$

PUERARIA (Kudzu Vine).

The most rapid growing vine in cultivation, often attaining a Tho growth of 40 feet in a single season. Especially desirable for
immediate effect for dense shade, as its leaves are large.
Doz. 10000

Thunbergiana (Jack-and-the-Bean-Stalk).

Small, pea-shaped, rosy purple flowers,

heart-shaped leaves. It will grow any-

where. Field-grown plants ........ \$3.00 \$25.00

\section{WISTERIA.}

Woody vines with tightly clinging habit, for pergolas, arbors, trellises, etc., especially ornamental in early summer when they are resplendent with their large, drooping clusters of fragrant blossoms.

sinensis (Chinese Wisteria) Bunches of Doz. $100 \quad 1000$ pale lilac, deliciously scented blossoms in great profusion all over the vine. Strong plants ................... \$5.00 \$40.00

Sinensis alba. A white-flowered form of the type. Strong plants ........... $5.00 \quad 40.00$

Wisteria Sinensis.
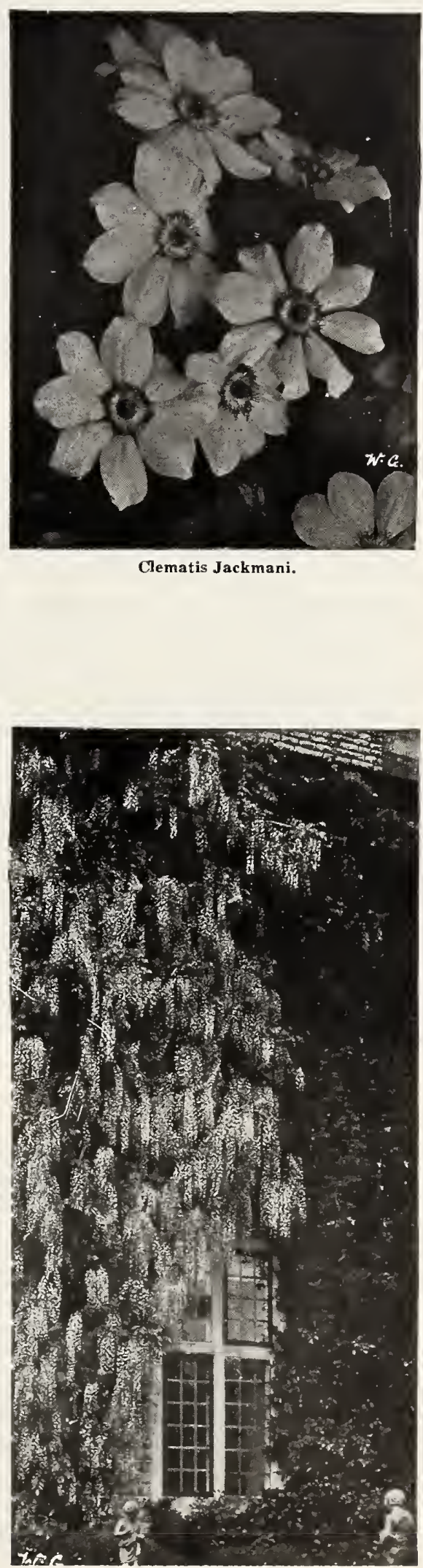

CJematis Jackmani 


\section{Hardy Shrubs and Azaleas For the Hardy Border or Rock Garden}

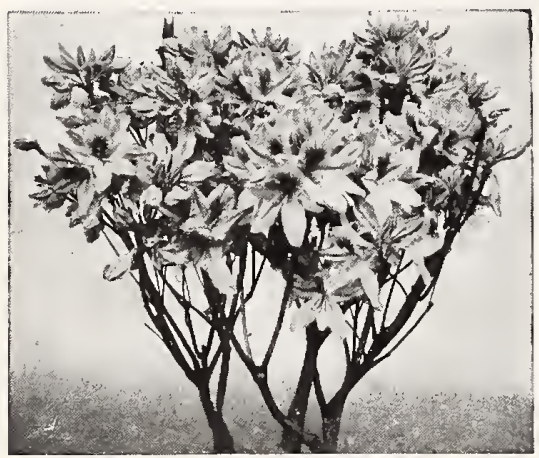

Azalea Mollis.

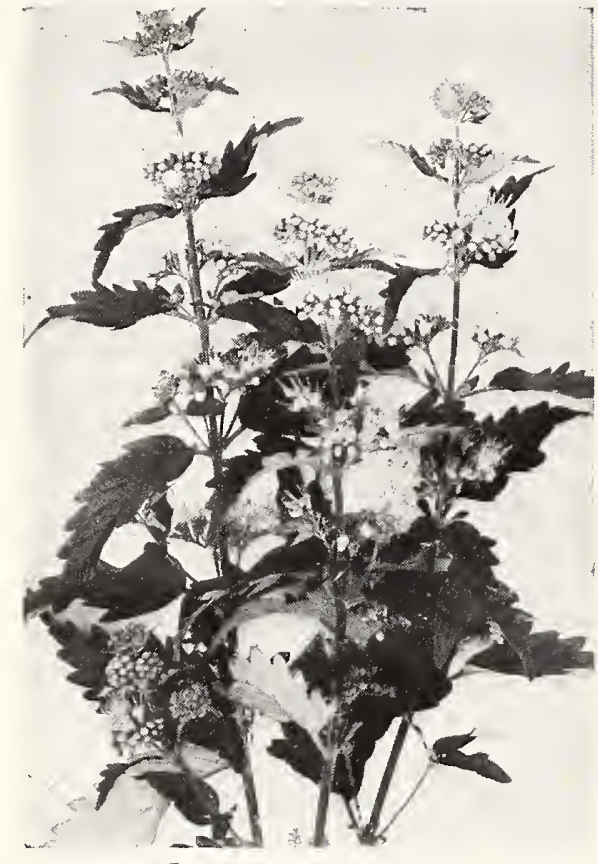

Caryopteris Mastacanthus.

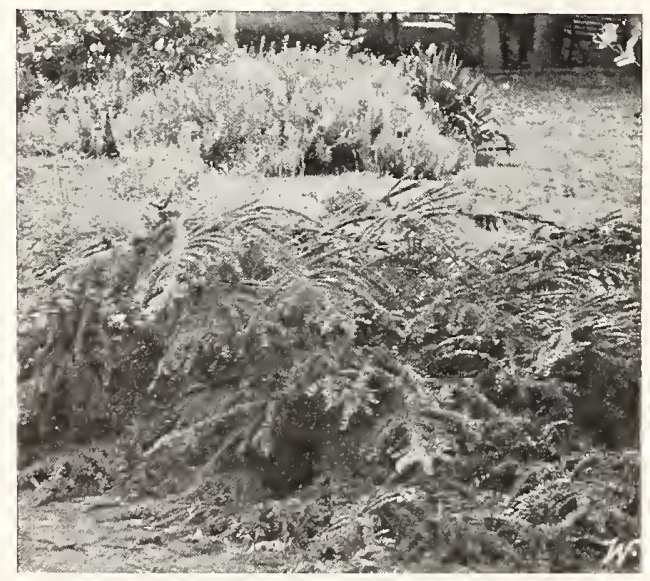

Cotoneaster Horizontalis.

\section{HARDY AZALEAS}

The varieties here offered are the hardiest and most desirable for general garden planting: until thoroughly established it is beneficial to rive them a heavy inulch of leaves during the Winter and a loose covering of evergreen branches to protect them from the sun and drying winds during freezing weather.

AZALEA (Pinxter Flower; Swamp Honeysuckle).

Amoena (Japanese Everoreen Each Doz. shrub with double purplish red flowers in May: is especially adapted for borders and rock gardens; needs some protection in northern latitudes. Should be planted in sheltered positions and will abundantly repay for any care given it .......\$2.00 $\$ 20.00$

Hinodegiri. Bright fiery red flowers. Bushy plants 10 to 12 inches high ................... $1.50 \quad 15.00$

Hinomazo. A wonderfully pleasing shade of delicate rose-pink. Bushy plants 10 to 12 inches
high $\ldots \ldots \ldots \ldots \ldots \ldots \ldots \ldots \ldots \ldots \ldots \ldots \ldots \ldots \ldots \ldots \ldots$
1.25

Ledifolia alba. Large pure white flowers. Bushy specimens, 18 inches high ............... 5.00

Macrantha, Very late-flowering large salmon-red Bushy plants, 10 to 12 inches high ........... $1.50 \quad 15.00$

Maxwelli. Large single carmine-red of dwarf spreading habit. Bushy plants, 8 to 10 inches
high Mollis (Japanese Azalea). Of dwarf habit; resembles rhododendrons; good foliage; flowers in all shades of red, yellow and orange; perfectly hardy, thriving in sunny positions anywhere. in contact with barnyard manure ............

Yodogawa. Large semi-double lavender-pink fiowers; the earliest to bloom. Bushy specimen plants, 24 inches high ............... 5.00

\section{HARDY SHRUBS}

Varieties Used With Herbaceous Plants in Hardy Plant Borders and Rock Gardens

The few varieties listed below are used to mix with hardy plants in borders and rock gardens.

BUDDLEIA (Summer Lilac).

Farguhari (New). A low-growing pendulous, spreading shrub, with rich green foliage and silvery reverse, bearing in late Sunmer long racemes of purple

flowers .........................

Thisils magnifica (Buttery the top usually freezes back, and new growth starts from the root like other perenstarts from the root like other peren-
nials. plants grow three to four feet nials. Plants grow three to four feet and are covered with long racemes of tion is in good, rich, well drained soil in a sunny situation ................... $4.00 \quad 30.00$

CARYOPTERIS (Blue Spirea).

Mastacanthus. A handsome hardy perennial; grows about 3 feet high and produces rich lavender-blue flowers in great profusion the whole length of the profusion the whole length of the branches. A valuable plant enther for bedding or pot culture, blooming contin-

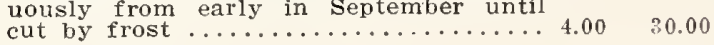

COTONEASTER (Rock Spray).

Horizontalis (Prostrate Cotoneaster). A low shrub with almost horizontal dark green, about half an inch long: flowers pinkish white; fruit bright red; attractive in rockeries. A most desirable ground cover, and should be largely planted. Cannot be transplanted unless planted. strong, 5-inch pot plants 
DAPHNE (Garland Flower).

Cneorum. Handsome dwarf sub-shrubs: excellcnt for planting near front of and handsome foliage.

Iarge clumps

DESMODIUM (Tick Trefoil).

Penduliflorum An exceedingly graceful slirublike plant covered with purplish led flowers in summer time. Strikingly

beautiful ..................... .50 4.00

Each Doz.

100

ERICA (Heath).

The Heaths are compact, low-growing plants, and as such are extremely useful for rockeries. The small foliage is densely arranged around the wiry little stems and either when in full bloom or in midwinter makes a very pretty picture Give some protection the first Winter Semi-shady location. All our Ericas are stiong, bushy plants.

Elata alba (White Heather). The nodding Each Doz. 100 white flowers are the only diversion from the Vulgaris; a pleasing contrast

Big clumps ...................\$1.00 \$10.00

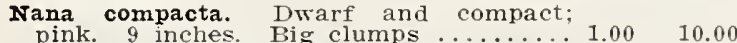

Vulgaris (Scotch Heather). A densegrowing shrub, with erect branches, covered with short, closely adpressed leaves. The pretty, hell-shaped flowers occur in great profusion toward tops of the shoots and are a pretty rosy color.

Big clumps

10.00

HYPERICUM (St. John's Wort).

Calycinum (Aaron's Beard). Rapidly growing sub-shrub and ground cover in sun or shade, with golden yellow flowers.

Henryi. The same as Moserianum; though slightly more upright in growth and much hardier and better suited for cold climates

100

1000

Moserianum (See page 26 ) $\ldots \ldots \ldots \ldots \ldots$

LEUCOTHOE.

Catesbaei. Large. A valuable plant with oblong, shiny foliage, dark green in Summer, turning to a hronzy red in the Fall. The fragrant white flowers are borne in pendulous racemes. Adapted for woodland planting .................. $\$ 1.00 \quad \$ 10.00$

VITEX (Chaste-tree; Hemp-tree).

Macrophylla. In general habit similar to $T$. Agnus Castus, but much stronger in all its parts, the foliage being larger while the trusses of lavender-blue flowers are fully double the size. It blooms from July to September; as popular as the Butterfly slirub, to which we consider it superior ...................... $1.00 \quad 10.00 \quad 90.00$

\section{HEDGE PLANTS}

\section{BERBERIS ( Barberry).}

Thunbergi (Japan Barberry). There a dwarf deciduous hedge is wanted, nothing equals this beautiful Barberry. Requires but little pruning to keep in shape. The leaves are small, light green, and towards Fall assume rich, brilliant colors, the fruit or berries be-
coming scarlet. Absolutely hardy.

Plant 12 to 15 inches apart.

inches high ................\$3.00 $\$ 20.00 \quad \$ 150.00$

\section{BOXWOOD.}

We are glad to be able to offer this valuable shrub again and at a price veryone can afford The Boxwood we are offering at a pice ereron stock we offer is bushy and wide excellent for edging walks or will stand a temperature of 10 below zero without any damage, providing the plants are protected with a little lath screen. admitting air and light. but giving enough shade so that the sharp sun during the months of December, January and Febuary, does not burn the foliage. Grows in any soil. Plant six inches apart

Boxwood Edging. We offer fine, bushy
plants as follors.
6 to 8 inches high
$\$ 3.00 \$ 20.00$
400
40.00
$\$ 190.00$
4.0

Doz. $\quad 100$

1000

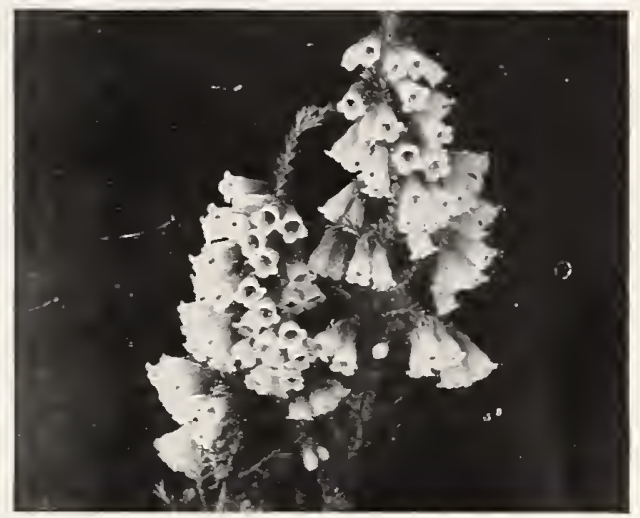

Erica-Heath.

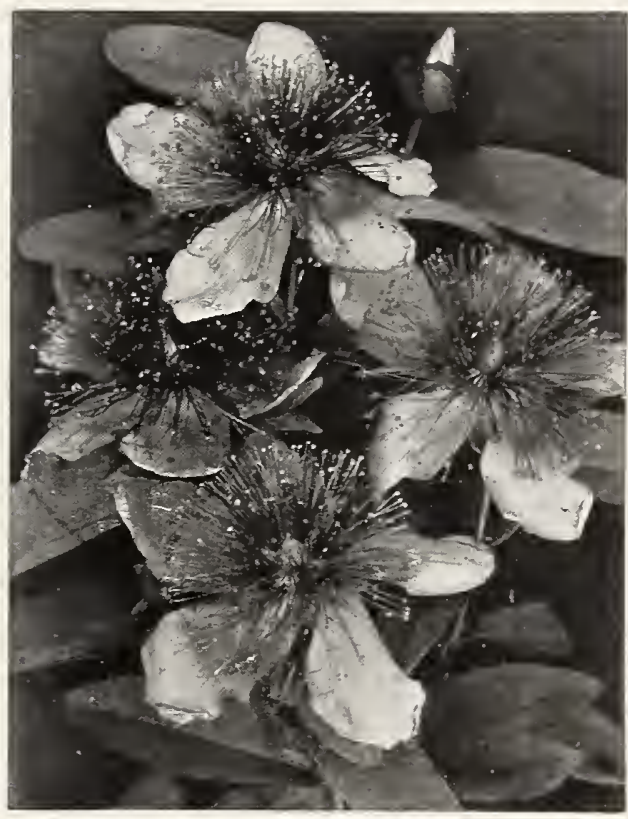

Hypericum.

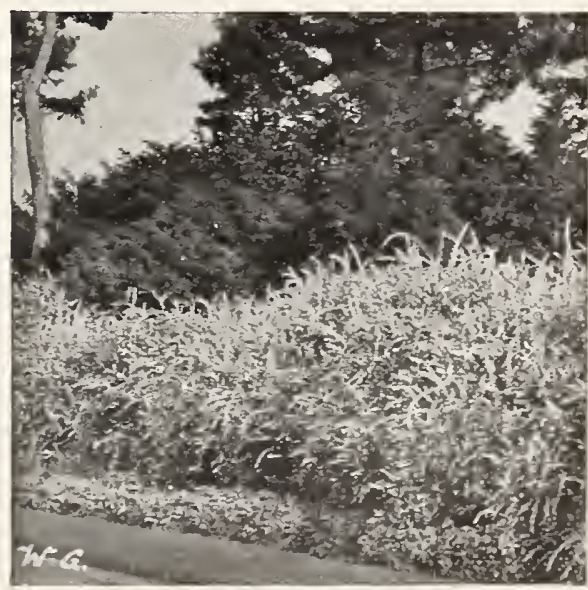

Barberry Hedge. 


\section{Bulbs for Hardy Border and Rock Garden}

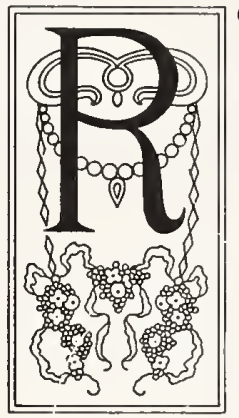

OCK GARDENING, during the past few years, has become very popular. Being the greatest producers of rock plants in this country, we have naturally been getting a great many requests from our customers to supply them with certain varieties of bulbs that might be suitably used in rock gardens. Unfortunately, the exclusion of Narcissi from this country has taken away from us one of our most valuable varieties of bulbs for this particular form of gardening! All tiny Daffodils, such as Narcissus Bulbocodium, commonly hown as the HoopPetticoat Daffodil; Narcissus Triandus Albus, known as "Angel's Tears:" Narcissus Cyclaminenus, or the Cyclamen Daffodil; Narcissus Moschatus, etc., and many others are being used in Europe in all rock gardens. However, we are still able to obtain the Wild Crorcus, and Wild Tulip species, and other small bulbs such as the Muscari, Scillas, Snowdrops, Fritillarias, etc. On page 64, for instance, you will find two very good collections of Wild Crocuses listed. One collection consists of varieties that bloom in the Fall during the months of September and October, while the other collection consists of early Spring-flowering varieties, blooming wherever possible in February or March.

Do not confuse these Wild Crocuses with the well known Dutch varieties. These we do not like to plant in rock gardens, but suggest their use for edging or planting in the lawn only.

Crocus Imperati, Zonatus, Speciosus, Tommasinianus, etc., are great favorites with everyone familiar witl rock gardening. Crocus Speciosus, Sativus and Zonatus, for instance, if planted between low-growing varieties of Sedum or Thyme, create a striking effect in October when flowers in rock gardens as a rule are rather scarce. It should be borne in mind, however, that in order to have success with these Wild Crocuses, especially Autumn-flowering varieties, they should be planted immediately upon arrival.

Tulip species, such as Tulipa Persica, Sylvestris, Clusiana, are a delight to watch when they put in their appearance early in April.

Erythroniums or Dog-tooth Violets, in varieties, are natives of this country, and we have made provisions to produce them on our own nursery so that we may be able to take care of the growing demand for these bulbs. There are, of course, innumerable varieties of semi-bulbous plants, such as Trilliums, Corydalis, Mertensias, etc., these can all be found in our hardy plant section.

\section{The Hardy Border Is Not Complete Without Bulbs}

Bulbs for the hardy border consist of a greater number of varieties than those that are suitable only for the rock garden. We do not believe the hardy plant border is complete without a liberal planting of Darwin, Cottage and Breeder Tulips, Narcissi and other bulbs. The most practical way to go about planting these bulbs in the border is to plant them under dwarf, shallow-rooting herbaceous plants. For instance, all varieties of Thyme and dwarf Sedums are excellently planted right over Tulips. There are also several varieties of Veronicas such as Veronica Rupestris, Amethystina, Royal Blue, True Blue, and several more, which will live in perfect harmony with bulbs. The Tulip or Daffodil bulbs which are planted underneath these dwarf herbaceous plants will last for a great many years.

\section{Ground Covers Require Special Care in Selection}

We have also often been asked to suggest ground covers for planting between Tulips, in beds, and in regular bulb gardens. We have noticed in several bulb catalogs information in regard to material of that sort which is rather misleading and impractical because of climatic conditions. Planting ground covers between bulbs is greatly in vogue in England, because it is not necessary to cover bulb beds in England with any straw or manure to protect them through the Winter. There are, of course, localities in the United States where this is not necessary, but in any state where the temperature drops to ten degrees above zero, it is essential that bulbs be protected in order to get the best results. Therefore, the planting of ground covers such as Arabis and Forget-me-nots, which are the two most pofular plants used, is always more or less dangerous, because neither of these two plants like a very heavy covering during the Winter.

Viola Cornuta, especially, makes a very fine ground cover, but if the Fall growth of these plants is damaged by a heavy covering, you will not get any blossoms at the time your Tulips are in bloom, therefore entirely defenting the purpose they were intended for. There are, of course, several more varieties of plants which can be used for ground covers or which may be planted in conjunction with bulbs. To anyone interested in carrying out an idea of this sort, we suggest they write us, so that we may recommend suitable material for this purpose in their respective locations.

\section{The Use of Lilies in the Rock Garden}

Lilies, rarticularly, have been grown successfully in hardy plant borders, but we recommend three varieties that may be used in rock gardens, and these are Lilium Tenuifolium, Rubellum and Krameri. All three are dainty, and are best planted in rock gardens where they can be given a sheltered location. All other varieties are splendid material for the hardy plant border. 


\section{Bulbs of the Highest Quality for 1926 IMPORTED TO ORDER ONLY}

\section{Darwin Tulips}

The Darwin Tulips were developed in the north of France, supposedly from choice varieties of Bybloem Tulips. Owing to the unusual clearness of the colors, to the substance of the petals, and to their vigorous growth, these seedlings, when they came into the hands of the prominent Dutch firms, seemed worthy of forming a new class of Tulips. In 1889 they were named in honor of Darwin, and offered for sale. They remained little known for a number of years but with the renewed interest in the Tulip, which sprang up in England at the beginning of the present larity here promises to exceed the favor they have enjoyed so long in Europe.

The colors include the blilliant scarlets and crimsons, and the more somber tones of red. The shades of rose and pink, of violet, and purple are unsurpassed for their delicacy or their richness of color. There are slate blues and blue-violets which might almost be called blue, while Dumas' "Black Tulip" is very nearly realized in some of the dark maroon varieties. There are no yellows. All the bronze and buff tones are Breeders: while bright yellow and orange-scarlet must be sought among the Cottage Tulips. The Darwins may be left undisturbed for two years,

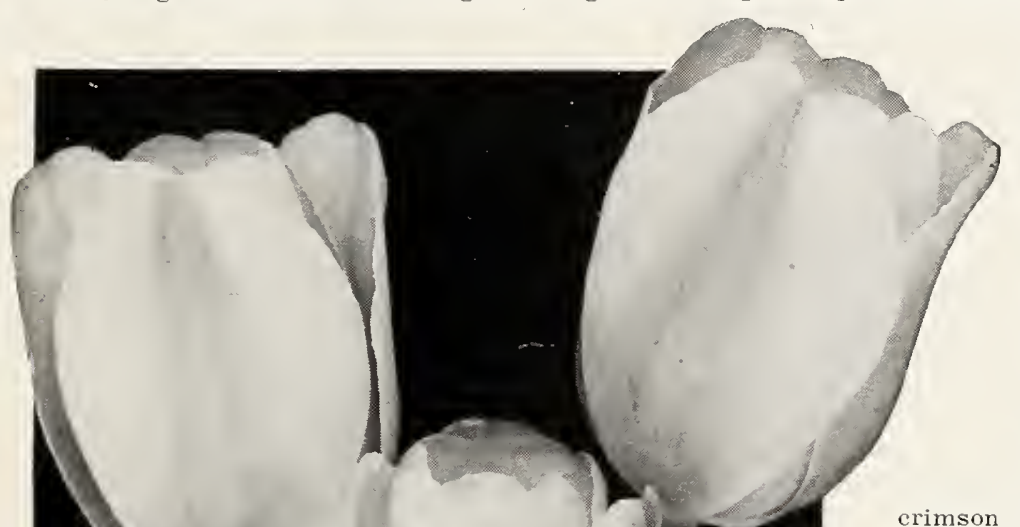
out it must be kept in mind that Tulips ar not long-lived in our soil and climate, but if iaken cale of, we have known them to last ten years. The collection offered in this catalog is made up from the best varieties offered for sale in Holland. All have beer tested at Wayside Gardens and we stand behind each one of them.

The figures following the name indicate the relative time of flowering.

Paronne de Bulbs Bulbs Bright rose, margined 4.

rose. Height 26 inches ....\$3.50 \$28.00

* Blea Aimable. 4. Pale laven-

der, with white base, starrod

der, with white base, startar

biue; beautiful flower of dis-
tinet shape. Height $25 \mathrm{in.} \mathrm{.} 4.00 \quad 35.00$

*Bartigox. 1. A very showy, shapeiy flower of good substance on strong stem; fiery crimson with pure white base, broadly ing deep blue. It is splendid for forc-

clara sutt. 4. Clear pink, flushed salmonrose; inside much deeper, with bluc base. Beautiful out-of-doors. Height 21 in. . . 3.00

*Crepuscule. 3. Lilac-white, with dark rosy flush at tips of petals; large flower.

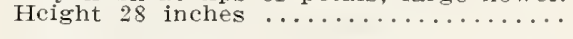

Cordelia. 3. Glowing crimson-violet with silvery flush on outer petals. White flower. Height 24 inches ............ 3.50

*Dream. 2. Pale heliotrope, inside deep violet with blue base. Height 27 inches. $3.50 \quad 30.00$

Duke of Portland 2. Bright

changing with age to bright garnet,

and blue base; a long flower of rich

color and fine form. Height 26 inches. 6.00 $\quad 55.00$

* Europe. 2. Salmon-scarlet, shacled rose with white base; medium sized flower on strong stem. Height 22 inches ....... 3.50

*Euterpe. Silvery lilae with rosy tone; dainty, coy, incurving of the edges of its makes a beautiful bed planted mith makes a beautiful bed planted mith

Feu Brilliant. The most glorious searlet Tulip ever raised; large and beautifully first to bloom; highly recominended. Height 28 inches $\ldots \ldots \ldots \ldots \ldots \ldots \ldots \ldots$.

*Faust. 2. Dark purple-maroon with blue base; very large flower. The best of the color. Height 30 inches

rlamingo. One of the most beautiful pink Tulips. Exquisite pure color and satin sheen. Lovely pointed flower. Beautiful in horder among Camassias, Nepeta Musconfuse with a Single Early Tulip of that name. Height 28 inches ............ 3.50 
Glory of Welworth. Heliotrope-lilac of a $\begin{array}{cc}100 & 1000 \\ \text { Bulbs } & \text { Bulbs }\end{array}$ very brilliant character:; Jarge flower on stout stem. Height 24 inches .........\$5.00 $\$ 45.00$

*Isis. 3. Crimson-scarlet with blue base; very large flower of striking beauty. A for borders or among shrubbery, and extra fine for forcing. Height 26 inches ..... 4.00

Jubilee. 3. Blue-purple with white base. Huge flower. The finest Darwin of this

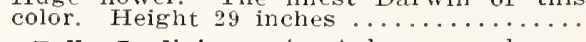

Ia Belle Jardiniere. 4. A large raspberryrose colored Tulip of great beauty; oval-
shaped flowers of good substance with a shaped flowers of good substance with a strong stem. A very attractive Tulip, good
for forcing and for the border. Most unusual color. Height 25 inches.........

* Ia Candeur; syn., White Queen 2. Almost white when mature; with black anthers;

*Ia Tristesse. 3. Dull slate violet with white base; large flower. Very distinct color. Handsome. Height 26 inches ....

* I Ta Tupe Noire. 3. Dark maroon-black, the blackest of all the Tulips. Large flower. Height 25 inches $\ldots \ldots \ldots \ldots \ldots \ldots \ldots$ stripe of duli old rose through center of petal, white base; very large flower. Height 27 inches $\ldots \ldots \ldots \ldots \ldots \ldots \ldots \ldots$...............

*Loveliness. 2 . Soft carmine-rose, paler at
margin; good size and of fine form. Lovely margin; good size and of fine form. Lovely 23 inches

Madame Krelage, 2. Bright lilac-rose, margined pale silvery rose inside soft rosepink; long flower. Height 28 inches .... 4.00

Maiden's Blush. 2. Rose, very fine, medium sized flower. Height 21 inches .........

* Massachusetts. 2. Vivid pink, edged rosy white; white base. Large flower of beauti-

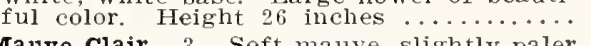

Mauve Clair. 3. Soft mauve, slightly paler white base. Height 26 inches ..........

* Melicette. 3. Soft lavender; inside dark lavender-violet with beautiful blue base The purest lavender Darwin. Height 25

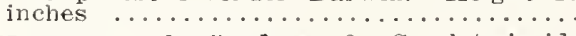

* Mr. Farncombe Sanders. 2. Scarlet; inside vivid cerise-scarlet with white base; large. among the reds. Height 25 inches .......

Mrs. Potter Palmer; syn., Mr. D. T. Fish, rashion.

* Nauticas. 3. Unusual tone of dark cherrypink. Vely beautiful grouped near Malus floribunda and white Wisteria with foreground of Iberis sempervirens. Height 39 inches. Record lreight in our trials, 39

Nora ware. 2. Light lilac, pale outside, shaded bronze

Painted Iady. 3. Creamy white, tinged soft heliotrope. The best white Darwin. Height 27 inches.............. * Philippe de Comines. 1. Purple-maroon:

* Pride of Haarlem. 1. Brilliant rosy carPride of Haarlen. 1 . Brilliant rosy carmine with blue base; vely large flower on passed for borders. Height 25 inches...

Faul Baudry. Dark violet-purple, shaded

Princess Ilizabeth. 2. Clear deep pink, changing with age to rose-pink, white base.

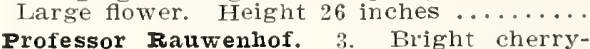
red with scarlet glow inside; brilliant blue base. Enormous flower on a strong stem.

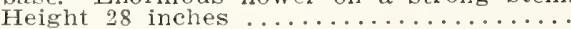

*Pysche. 1. Silvery rose, edged sof rose; inside shaded silvery rose with pale base. Large flower. Height 26 inches ........

Queen Mary. 2. Cerise-scarlet, edged deep pink: inside brilliant saimon-pink, with bright blue base; a large flower of very
clear color. Effective in any outdoor sit-

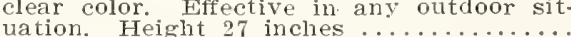

$3.00 \quad 36.00$

\section{$*$}

*Reverend Ewbank. 2. Soft lavender-violet with silvery gray flush, white base; good sized flower of beautiful color. Height 22 inches ...................... \$3.50 \$30.00

Scarlet Beauty. 2. Pure glowing scarlet. Extra large flower. Height 22 inches.

spring Beauty. 2. Glittering red Tulip, superb for distinct effect against green. The finest red Tulip. Height 26 inches . . $3.75 \quad 32.00$

*Valentin. 1. Soft heliotrope, shaded violet; inside heliotrope with blue base; large flower on tall stem. Height 22 inches ...

Van Poortvliet; syn., Minister Tak Van Poortvliet. Bright rosy scarlet with a blue
base; large flower on tall stem. Award of base; large flower on tall stem. Award of
Merit R. H. S. London, 1901. Height 24

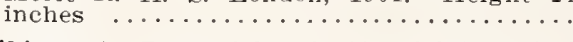

Viking. 4. Deep violet; inside violet, flushed brown with blue base. Large, open flower.
Height 27 inches ..................... 4.50

Viola 3. Dark violet, strong, large

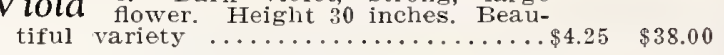

*wally Moes. 3. Pale lavender, penciled

with rosy lilac. Inside dark lavender,

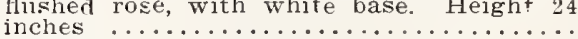

William Pitt. 2. Very dark crimson, with furplish bloom on the outer petals and white base starred blue; large flower of distinct color and great beauty. Fine for borders and for forcing. Height 22 inches. $4.75 \quad 42.00$

william Copeland; syn., Sweet Iavender. 1. Lilac-rose; not a large flower but of merit because it may be forced as easily as the early Tulips. Height 25 inches ......... Zulu. ${ }_{\text {purple }}^{2 .}$ Rich, velvety black with shining
edges; large, egg-shaped flower purple edges; large, egg-shaped flower. $3.75 \quad 32.00$

Superb Mixture of Darwins. This is our own special mixture which we recommend where the best results are desired in beds of mixed colors. It is made up of the above named sorts and in equal propor-

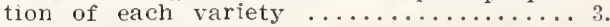

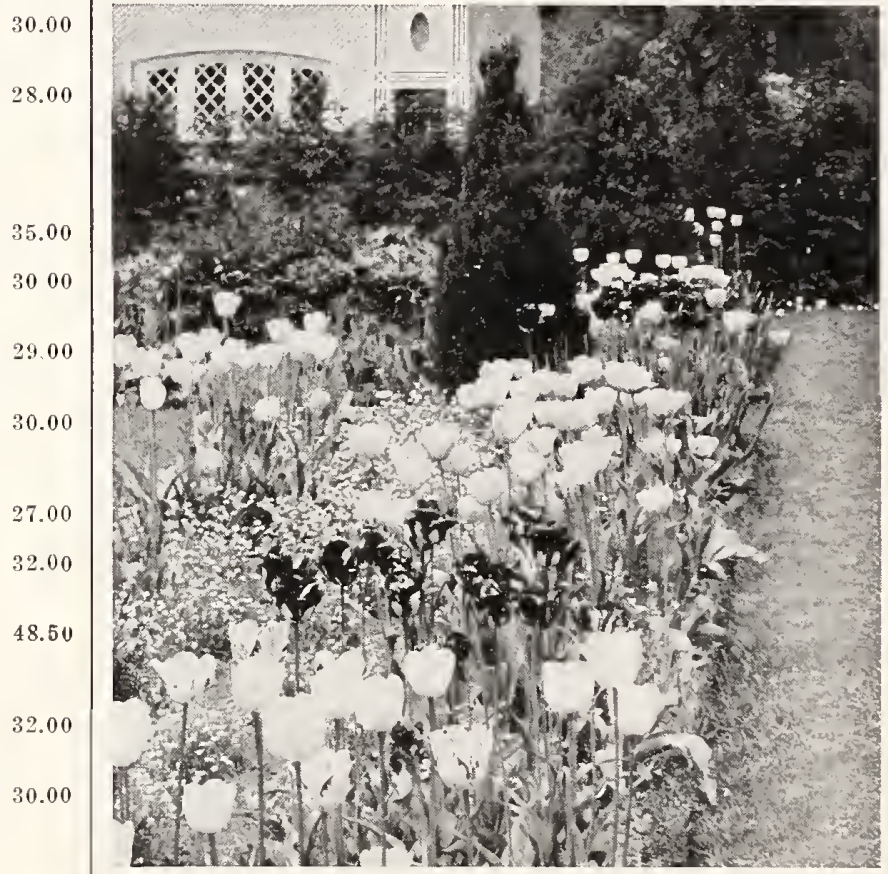




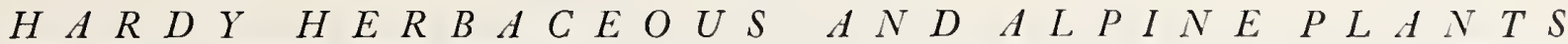 Famous Old Dutch Breeder Tulips}

The Breeder Tulips have been favorites in Holland for centuries, but it is only within recent years that they have become known and appreciated in America, and now they bid fair to rival tole lyarin Tulips in populality.

Their majestic size and remarkable colors place them distinctly in a class by themselves Every lovel of the more somber shades cannot fail to revel in the rich and artistic blendings of purple and old gold, bronze and terra cotta, brown and violet, and buff and maroon found among the Breeders. Ther are late to bloom but surpass in size and vigor the Darwins, although lacking the color brilliancy of the latter. The flowers are, many of them, sweet scented, and all splendid for cutting, as they retain for a long time their form and color.

Abd-el-Kader. Dark copper-bronze, lighter border; very beautiful .............\$6.00 \$57.00

Apricot. Dull, bronzy buff, shaded ruddy

apricot above base ...............6. 6.00

Bronze Queen. Soft buff, inside tinged golden

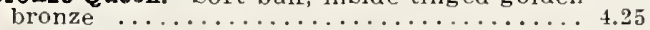

Cardinal Iranning. Dark rosy violet ..... 5.00

Chestnut. Tery dark brown, almost black.. 3.75

Dom Pedro. Coffee-brown maroon, shaded;

best of the brown varieties ........... 7.00

Golden Bronze; syn., Toison d'Or. 3. Light brownish yellow, with faint flush of within, shading to golden brown at tip of petals, yellow base. The generai effect at a distance is a bright yellowbrown. Height 24 inches .......... 4.75

Godet Parfait. Bright violet; striking color; extra large flowers which keep wonder-

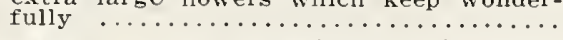

Famlet. 3. Dull coffee-brown, with faint flush of rosy purple through center of petals; inside dark maroon with yellow base; a flower of good size. with slightly base: a flower of good size. with slightly reflexing outer petals. A distinct color and splendid for contrast with the paler
late Tulips. Height 26 inches ........ 4.50

Jaune d'oeuf. Well formed, large flower on tall stem; bright. deep lemon-chrome, with a slight flush of pale purple on the outer segments; large, pale green base: filaments greenish. Height 28 inches.. 5.0

Klopstock. A very handsome Tulip; bishop's purple, margined with purplish lilac, inside rosy lilac, edged rosy white, large, pale yellow base, with blue star.

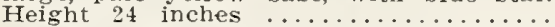

Ie Mogol. Pale, silvery lilac, passing into white, interior deep mauve-lilac with fine white base and blue halo. Not a large flower but exquisitely colored. Height

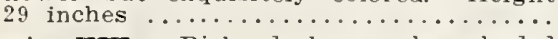

Iowis XIV. Rich dark purple, shaded steel-blue, heavily flushed bronze, edged golden brown; enormous size and stately bearing $\ldots \ldots \ldots \ldots \ldots \ldots \ldots \ldots \ldots \ldots \ldots \ldots$.

ucifer. Bright terra cotta-orange, enor-

Marie Iouise. Very handsome flower of old rose, flushed orange-salmon, edged bronzy orange; olive base, Height 24
inches $\ldots \ldots \ldots \ldots \ldots \ldots \ldots \ldots \ldots \ldots \ldots \ldots \ldots \ldots \ldots$

Mon Tresor. Indian red, with orange tone at edge of petals; inside dull blood-red, with yellow base marlied bronze: a medium sized flower; quite distinct. Height

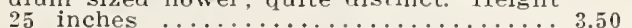

Panorama (Fairy). Large, goblet-shaped flower: rich chestnut-red; base and filaments chestnut-brown. Height 26 inches. 5.25

Prince Albert. Glowing mahogany-brown, shaded dull bronze, green base. Splendid

Prince of Orange. Large, very showy, well formed flower of great substance; terra cotta, edged orange-yellow, base indefinite yellow, streaked with olive, flaments olive. Height 26 inches . . ............ wite: white to

Turenne. Dark blue, heavily flushed bronze

at margin: very large flower bud ........

velvet King. Immense flower on extra elvet king. Immense flower on extra
strong stem. Its robust growth makes it strong stem. Its robust growth makes ous; fine cup-shaped form: bright, dark, ous, ine cup-shaped form: orite, sharply deroyal purple, small, White, sharply defined base. A giant. Magnificent planted
in masses of yellow Pansies, or dotted in masses of yellow Pansies, or dotted heliotrope Darwin Tulip, Dream. Heigh 31 inches
56.00

35.00

45.00

32.00

67.00

42.00

6.00

56.00

48.00 4.00

36.00 $8.00 \quad 175.00$ $9.00 \quad 185.00$ $5.25 \quad 48.00$ 30.00 47.00 52.00 8.7

0.00 ellow Perfection. A large flower of remarkable beauty. Light bronze-yellow, brown, yellow base starred green. Height 26 inches ......................... \$5.0 \$45.00

\section{Choice Mixed Breeder Tulips}

Mixed bulbs, as a rule, do not appeal to the planter of bulbs because it does not make possible the blending of colors. Breeder Tulips, however, are in a class by themselves and their colors do permit easy blending. They are in shades of bronze, golden bronze, violet, buff, maroon and terra cotta. We suggest a liberal planting for cut flowers.

Per hundred, $\$ 4.00$.

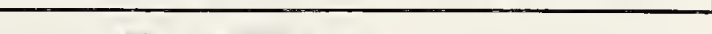




\section{Cottage or May-Flowering Tulips}

The Cottage Tulips come into bloom in early May, after the Early Single varieties have passed. They are hardy and robust, with iong, slender, but very stiff stems. The flowers are mostly long and oval, many of them with the petals gracefully reflexed. The cottage Tulips as a class are rich in the more delicate ard artistic shades of yellow, orange, and fawn with salmon, old rose and amber. They are the best of all Tulips for cutting and they develop best when planted outdoors, including the earlier kinds.

Bouton d'or. The finest and deepest golden $100 \quad 1000$ shaped flower of mediack anthers. cutting and for mass effect: if planted amongst anded amongst blue Anchusa myosotidifiora, or have them rise in quantity from a solis bed of white violas or Arabis, they wil make a striking picture. Very effective also if massed against evergreens or lilacs. Height 20 inches ................... $\$ 3.25 \$ 29.00$

Elegans. A grand Tulip; very showy; rich crimson-scarlet; large flower ........... $3.50 \quad 30.00$

Ellen willmott. One of the finest May-flowering Tulips. Flowers very large, beautifully shaped, soft creamy yellow, deliciously fragrant $\ldots \ldots \ldots \ldots \ldots \ldots \ldots \ldots \ldots .4 .00 \% 35.00$

Fairy Queen. Effective association of lilac and amber; heautiful silvery heliotrope shade when forced. Large flower; one of the most lovely of Cottage Tulips. Height

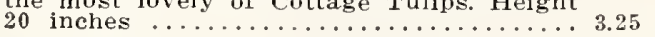

Gesneriana Irioides. 4. Soft primrose-yellow, with black base; egg-shaped flower of medium size, attractive for the contrast between the base and the rest of the flower. Height 22 inches .................... $4.50 \quad 40.00$

Gesneriana Iutea. Warm yellow flower of fine form. Fine for herbaceous borders ame form. Fine for herbaceous borders Height 24 inches $\ldots \ldots \ldots \ldots \ldots \ldots \ldots \ldots \ldots .25 \quad 28.00$

Gesneriana spathulata. The finest of the Gesneriana group. Rich ruby-crimson flower with a blue base, and long, slender segments. Makes magnificent beds or is splendid massed against evergreens. Height

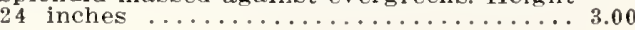

Grenadier form and good substance borne on strong stem; dazzling brilliant orange; yellow base. Especially recommended for planting here and there in the borders in clumps for "high spots" in your color schemes. Height 21 inches .............. 5.75

Golden Spire. Orange-yellow; large flower, pointed, reflexing petals ................... $30 \quad 31.00$

Inglescombe Pink. Salmon-pink, blue base; very brilliant. 1000 bulbs, $\$ 40.00 \ldots \ldots \ldots 3.25 \quad 27.00$

Inglescombe Yellow. Glossy canary-yellow. Large, globular flowers. Has the true shape of the Darwin Tulip, hence is called the Yellow Darwin .................... $30 \quad 30.00$

John Ruskin, Salmon-rose, edged lemonyellow; inside deep rosy lilac, with margin of yellow; large flower of fine shape.
Height 16 inches $\ldots \ldots \ldots \ldots \ldots \ldots \ldots . \ldots \ldots$

Ia Merveille. Orange-scarlet, flushed rose, with yellow base; very long, large flower of exquisite form, deliciously scented. A

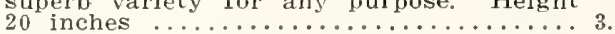

Orange king. 4. Glistening deep orange, $100 \quad 1000$ shaded rose; inside deep orange-scarlet with yellow base; sweet scented; a globular flower of great size and brilliant coloring. Most attractive for beds or borders. Height 23 inches $\ldots \ldots \ldots \ldots \ldots \ldots \ldots \ldots \ldots \$ 3.75 \$ 30.00$

Parisian Yellow. Golden yellow; pointed ... $3.50 \quad 30.00$

Picotee or Majden's Blush. Long; clear white; the petals, which are pointed and elegantly reflexed, are beautifully margined and penciled on edges with bright pink ........ $3.25 \quad 28.00$

Sir Harry. Fine mauve-pink, broad base, lightly waved petals. Fine for cutting and for planting among grey-leaved plants. Height 26 inches .................... 4.50

Summer Beauty. Rose, flaked crimson and white; large and lovely flower ........ 4.75 42.00

The rawn. Pale rosy fawn, changing to cream, flushed blush-rose; large, eggshaped flower of exquisite beauty on graceful stem. A gem among late Tulips.

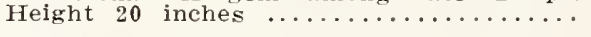

Vitellina. Sweet-scented creamy flower of large size; has fragrance like that of the orange. Looks well planted with some clear pink variety. Forces well. Height 20 inches ......................... $4.50 \quad 40.00$

Special Mixture of Late Single Tulips .... 2.75

Mr. Moon. Pure yellow, large. The best of

all yellow late Tulips; sweet scented ... $5.00 \quad 45.00$

Moonlight. New. Light, soft yellow; enormous flower ................... 4.00

Always state on your order blank if we are allowed to give you a similar variety of bulb if we are sold out of the kind you order. We of course will send you a color as closely resembling the one you order as possible and of the same price. 


\title{
Parrot Tulips
}

We urge you to grow some of these quaintly shaped flowers particularly for house decoration. The artistic forms and colorings make them especially suitable for cut flower purposes; in the garden, if planted in borders or groups, they are not always satisfactory, as they lack the vigorous, straight stems of the other Tulips with the exception of one variety, the beautiful novelty "Fantasy" which has as straight and tall a stem as a Darwin Tulip. All Parrot Tulips are extremely effective planted in long drifts in front of evergreens.

$$
\begin{array}{cc}
100 & 1000 \\
\text { Bulbs } & \text { Bulbs }
\end{array}
$$

Admiral de Constantinople. Deep

cramoisi Brilliant. Rich blood-

crimson with blackish markings;

very large and handsome ....

fused scarlet; very large ....

Perfecta. Golden yellow, blotched

deep scarlet

\author{
3.50
}

\author{
3.50
}

3.50

\section{Rembrandt Tulips}

When the coloring matter of a "self color" has become split up into stripes and blotches, that particular flower is called "broken" or "rectified," When the Darwin Tulips "break" into these variations, they are called "Rembrand" Tulps. They are very decorative but should be planted by themselves or in combination with the "Bizarres" and "Bybloemen" which are the broken forms of the Breeder Tulips. All require the same cultural treatment as the other May-flowering Tulips, blooming during the month of May in our latitude, and about a month earlier in far southern sections. In our list we offer what we consider the finest varieties. $\quad 100 \quad 1000$ Finest Mixed Rembrandt Tulips ....... \$5.00 $\$ 45.00$

\section{Lily-Flowered Tulips}

As the result of crossing the dainty pointed-petaled Tulipa retroflexa with a pink Darwin, we have here a new, graceful, slightly reflexing flowers on tall, sturdy stems.

Retrofleza. Most effective on account of its Bulbs Bulbs

simple beauty. The form is particularly

impressive; the corolla in its lower part

fills out roundly and delicately like an urn

then is somewhat contracted upward and

again curved outward at the point of the

three outer and narrower sepals. The stem

has that slight amount of curvation which

formality. The color is a fresh honey-yel-

low, extremely beautiful: one of the most

elegant of the family. Should be planted

in groups of twelve to twenty-five among

in groups of twelve to twenty-nve among

no other Tulip can. Very effective if grown

in masses against purple Persian Lilacs and

white-flowering shrubs. Height 18 inches. $\$ 4.00 \quad \$ 35.00$

* Sirene. A very beautiful flower. Rich cerise-

pink with pale pink at the margins of

segments, white base. Fine forcer. Great

$6.00 \quad 55.00$

\section{Mariposa, or Butterfly Tulips (CALOCHORTUS)}

Until one has seen a good collection of

ture can do in the variation of one flower.

All Mariposas are forms of Calochortus, yet

there ale several strains, all with the slender grace of stem belonging to the species.

Cup-shaped flowers ine to many on a stem, wonderfully marked with eyes and dots and pencilings in rich colors, are charaz teristics. Yet each strain carries out the plan on a color scheme of its own, and then can be compared only with the orchids in wonderful variability of beauty.

"Mariposa" is simply the Spanish word for butterfly, and is applied to these Tulips be cause the eyes and markings of the flowers are so much like those on a butterfly's wings. The bulbs are small and should be planted

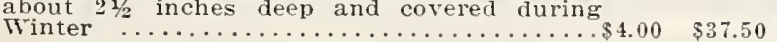

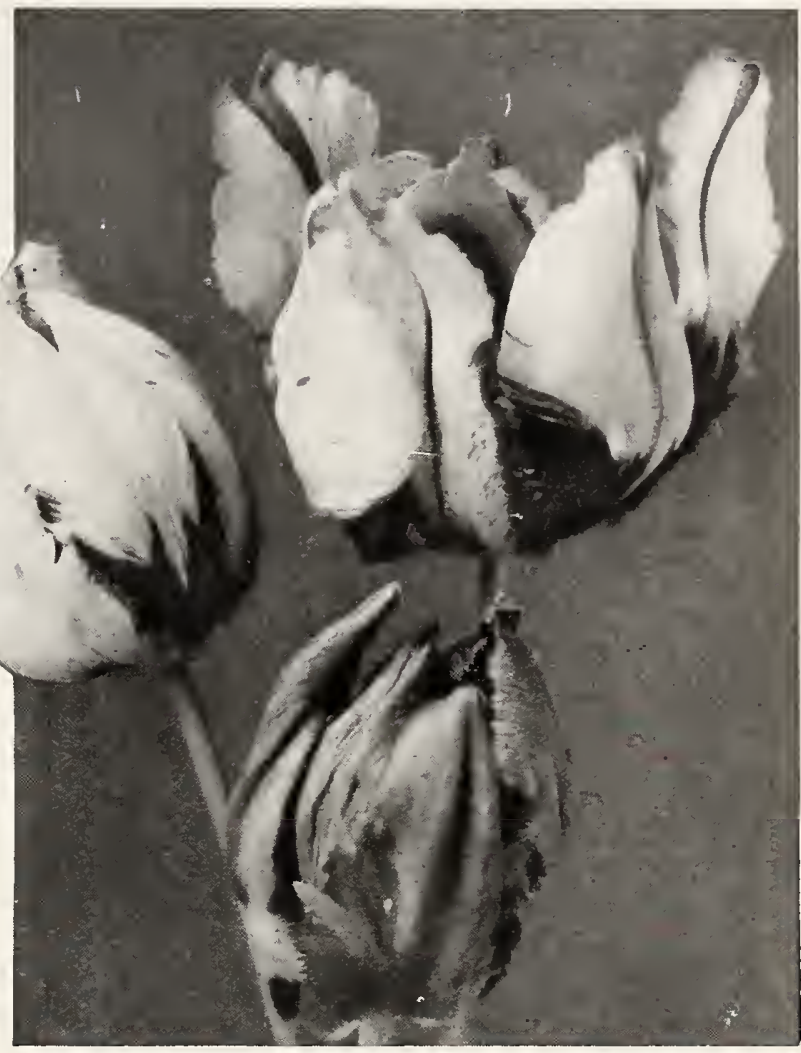

Parrot Tulips.

\section{Bunch-Flowered Tulips}

A new type producing many flowers on a stem; very unusual and handsome; fine cut flowers. 100,1000 Monsieur Mottet. Ivory-white flowers. Height 18 inches. 4 to 6 flowers on one

\section{Bizarre and Bybloem Tulips \\ OLD DUTCH TULIPS} are not quite so tall nor so large and show off to best advantage planted by themselves or with the Rembrand Bizarres and Bybloemen Tulips Mixed. In
fine mixed varieties, selected by us ..... $\$ 4.00 \quad \$ 36.00$

\section{Botanical Tulips and Wild Species}

\section{wonderful for the Rock Garden.}

The general characteristics of the of which are natives of Asia Minor and Central Asia, are bright colors and recurved petals. These Tulips do not two, or possibly three, seasons, they will disappear. With care and the provision of suitable quarters they will flower quite satisfactorily. They feel best contented in rock gardens and borders. Clusiana. Outer petils bright cherry-red, inner petals creamy white, with violet base, small flower, but very distinct and beaulsful. It should be planted in light soil 6 or 9 inches deep, in the ruck garden or border. A warm and sheltered situation should be chosen, where it will prove to be a gem among early-flowering Tulips. Known commonly as "The Lady Tulip." Flowering season late April. Height 8 inches ......

Florentina Odorata. Deliciously fragrant, butter-yellow blossoms, often two to a stem, with bronze exteriors, carried on
slender, arching stem. A charming species slender, arching stem. A charming species that increases rapidly when once estabHeight 18 inches 


\section{Single Early Tulips $\begin{gathered}\text { Including the Best of the } \\ \text { Recent Introductions }\end{gathered}$}

They are the best fitted of all Tulips for forcing, and, if not grown too cool, some very early varieties may be had in flower by the end of December. When used for bedding, it is far better tlat new bulbs be secured each year, for the old bulbs will not do well the second season unless they have been allowed to mature and the foliage to die down before being removed from the beds. Even with the best care, it is uncertain whether the bulbs will again bloom successfully during a second season.

In the following list the handsomest sorts alone are represented, while many of the better known varieties are omitted because they are surpassed by the newer kinds. Detailed planting directions are included with the invoice.

$\begin{array}{cc}100 & 1000 \\ \text { Bulbs Bulbs }\end{array}$

Couleur Cardinal. Outside bronze-scarlet, in-

Fine for bedding and late forcing f......\$5.00 \$44.00

Cottage Maid (Ia Precieuse). Bright pink.

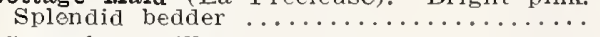

*ramoisi Brilliant. Brilliant scarlet. A
splendid bedder and sure forcer. Very splendid bedder and sure forcer. Very

De wet. Beautiful deep orange, shaded golden yellow at the base of the petals. A very artistic flower and one of the finest newer sorts in cultivation. There is no other orange variety which equals it in brilliancy. It is, therefore, one of the showiest bedders, and as it forces splendidly, we recommend it for all purposes..

Flamingo. White, flaked bright carminerose. A sport from White Hawk, having its artistic shape with its more or less

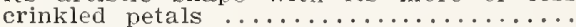

* Fred Moore. Very handsome bright orange, shaded with scarlet; splendid for forcing.

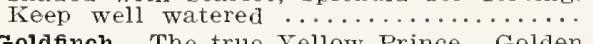

*Goldfinch. The true Yellow Prince. Golden yellow; sweet scented. Forces easily and early; lasts long when cut; letains color.. with bright yellow. A good forcer. Height 16 inches

* Lady Boreel. The finest pure white Tulip, either for beds or forcing. Flowers o beautiful form, long and slender. Height
16 inches $\ldots \ldots \ldots \ldots \ldots \ldots \ldots \ldots \ldots \ldots \ldots \ldots \ldots$

* Ia Reine Maxima. A lightly flushed white Tulip of large size. Makes chalming bed with lavender Violas. Splendid for forc-

Ie Reve; syn., American Lac; Hobbema; Sarah Bernhardt. 4. Old rose; very large flower on a strong stem. Beautiful when grown out-of-doors. Fine for late forcing. Height 13 inches

*Mon Tresor. Pure golden yellow; extra fine, large. One of the best and easiest forcers. 5.00

* Proserpine. An enormous globular flower of carmine, shaded rose; delightfully scented. Plant among pink Forget-me
nots. One of the earliest to force. 14 nots. one of the earliest to force. 14

President Iincoln; syn., Queen of the violets. Clear magenta-violet, large flower. Very effective when grown beside a light yellow Tulip, such as splendid forcing sort. Height 12 inches. 4.50

Prince of Austria. True orange shaded scarlet; vely fine ................. ered white; flowers of unsurpassed

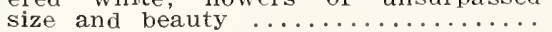

Rising Sun. Very deep golden yellow; long. huge flower of very handsome form and habit. A sport of Duchesse de Parma, which excels ali vellow Tulips for bedding or forcing. Height 16 inches

* Rose Iuisante. Dark silky rose; the finest rose variety. Both a forcer and bedder

*Vermilion Brilliant. Bright vermilion best of its class. Forces very readily

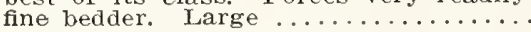

White Hawk. This is a blush white sort, and is as popular as any early Tulip. Flowers large and of fine substance ... 4.

superb single Mixed. This is our own special mixture which we recommend where the best results are desired in beds of mixed colors. This mixture is made up of hundreds of named sorts and in equal proportions of each variety.

40.00

42.00

57.00

\section{Double Early Tulips}

The double varietjes cannot be forced so early or readily as the singles. One of the earliest, Salvator Rosa, may be had by the middle of January, while varieties preceded by a (*) may be flowered from January to March. The flowers are large and brilliant and are effective in beds or groups. If grown in pots, do not attempt flower-
ing before they are well rooted.
Bulbs Bulbs

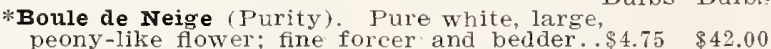
*couronne d'or. Golden yellow flushed orange; magnificent; of great beauty and size; strong stems, holding flowers upright; fine forcer $\ldots \ldots \ldots \ldots \ldots \ldots \ldots \ldots \ldots \ldots$............. beautiful rose, feathered violet: a handsome novelty, unexcelled for exhibition

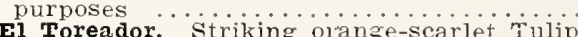
edged with yellow. Makes a splendid bed and forces well. Height 12 inches.......

Mr. Van Der Hoef. A yellow sport of ifurijo with all its superb qualities. One of the With all its superb qualities. One of the very finest of the primrose-yellow double
Tulips. A very lovely flower. Height 13 in

Murillo. Delicate biush pink A very fine flower with a lovely color. An old variety but still one of the handsomest of the double Tulips. It forces very easily $\ldots$. . . pink flowers, fushed, pink fowers, fushed white. This magnincent variety created a sensation when first exhibited by us at the International Flowdecoration and lasts a long time cut or in

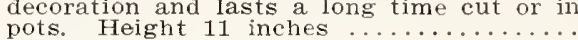
pots. Height 11 inches ...............
* Safrano (Tea Rose). Of a pleasing saffronyellow as the old tea rose
vurbaak. Bright searlet; splendid bedder vurbaak. Bright scarlet; splendid bedder;
large, well shaped flowers on strong stems.

Double Mixed. This is our own special mix

ture which we recommend where the best results are desiled in beds of mixed colors. This mixture is made up of the best named sorts and in equal proportion of

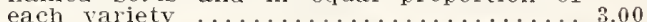

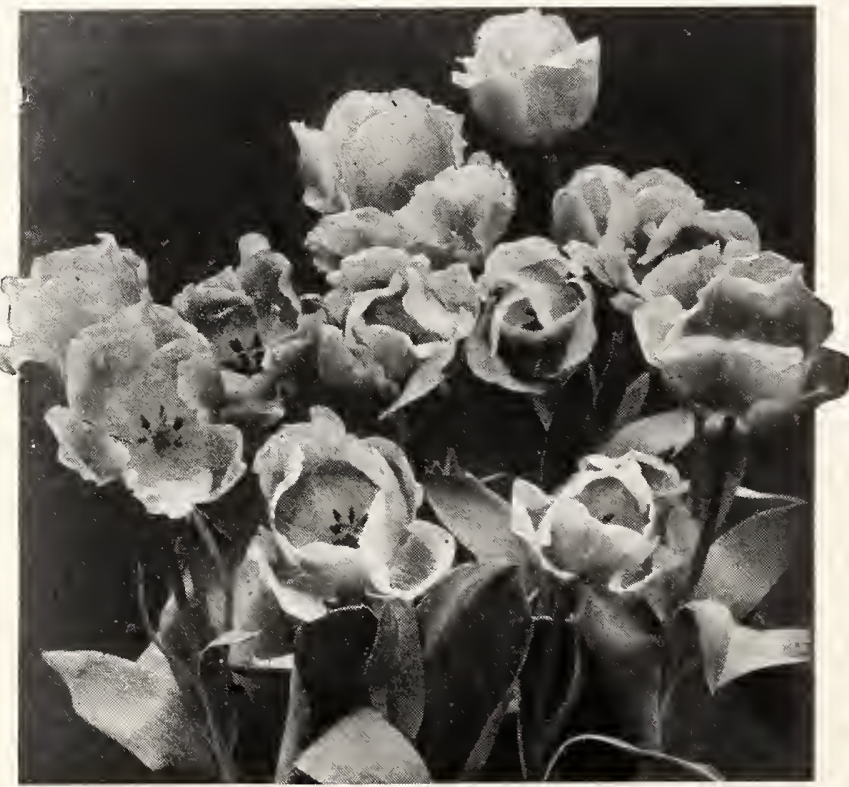




\section{Narcissi - Daffodils \\ (American Grown)}

Daffodils are not particular as to soil and will thrive for a number of years in ordinary soil. They are, with few exceptions, suitable for naturalizing, and, while preferring partial shade, will thrive in full sun exposure. They are very desirable for pot culture, three to five bulbs in a 5- or 6-inch pot producing an attractive group. By planting varieties in succession, a gorgeous display may be enjoyed throughout the first three months of the year.

\section{Yellow Trumpet Daffodils}

Varieties with yellow or primrose trumpets and petals of the same colors.

Bulbs Bulbs

Emperor. Large, rich yellow trumpet; prim-

rose perianth; fine for cutting .......\$9.00 $\$ 80.00$

Glory of Leiden. Trumpet yellow; perianth

soft yellow; of largest size and always

Golden Spur. Large lobed trumpets, rich,

deep self-yellow; perianth large and

spreading; early flowering ............ $9.00 \quad 80.00$

King Alfred. Uniform golden yellow; this

variety stands unrivaled in size and beauty.

Its round, flestiy petals, its immense, ele-

gantly recurved and beautifully fluted

trumpet, and its sturdy growth proclaim

it the King of Daffodils.................. $17.00 \quad 165.00$

\section{Bicolor Trumpet Daffodils}

The perianth white or light colcred, with yellow trumpet.

Empress. Very large and beautiful whit perianth; rich yellow trumpet ... White Bulbs Bulos Giant Princeps. Sulphur perianth and yellow trumpet: long and showy 1001000 Bulbs Bulbs

$7.50 \quad 65.00$

Victoria. Large, erect flowers; creamy white perianth and rich yellow trumpet; forces easily ................................. 9.00

\section{White Trumpet Daffodils}

Tadame de Graaff. Perianth white; trumpet

\section{Narcissus Leedsi}

Fragrant Star Narcissi, all having white perianths.

Mrs. Iangtry. White perianth and white cup; Queen of the North. Large, glistening, showy white perianth; cup primrose-yellow with a narrow eage of creamy white. A con spicuous and beautiful Daffodil ........ 10.00

White Iady. Broad white perianth; dainty cup, shaded soft lemon. Beautifully
crinkled. A very pretty flower ........ 10.00

90.00 crinkled

\section{Poet's Narcissus}

Ornatus. Native of France. Early; pure white cup, margined scarlet. Double crown bulbs .......................................

Poeticus recurvus (Pheasant's Eye). Pure
white perianth, cup edged saffron. Fine White perianth, cup edged saffron. Fine
for naturalizing $\ldots \ldots \ldots \ldots \ldots \ldots \ldots \ldots \ldots$

\section{Narcissus Incomparabilis}

These are known as the Chalice-Cup Daffodils, and like all the short-trumpet varieties, they possess a certain elegance and airy grace which is not to be found in the giant-trumpet class. All of them naturalize readily.

Autocrat. Broad perianth primrose-yellow $\begin{array}{ll}100 & 1000 \\ \text { Bulbs } & \text { Bulbs }\end{array}$ cup golden vellow. Very free-flowering and one of the best for forcing .........\$10.00 \$95.00

Iucifer. Large, sulphur-white, loosely formed perianth; cup chrome-yellow, edged bright orange-red ...................... 100

Sir Watkdn (Giant Welsh Chalice Flower). Largest of the Incomparabilis varieties; fine for forcing; cup yellow; perianth primrose

\section{Narcissus Barri}

Varieties of the Star Narcissus class. Very useful for pots, cutting or borders. This class is one of the best for naturalizing in front of shrubbery and will increase from year to year, making in time a very effective colony. 1000

Bulbs Bulbs anth.

blooming and durable cut flower variety .\$9.00 \$80.00 seagull. Broad, pure white perianth; pale lemon-yellow cup. Dainty but of good substance; excellent for all purposes $\ldots . .13 .00 \quad 125.00$

\section{Poetaz Hybrid Daffodils}

An altogether new race of Narcissi, crosses between Polyanthus and Poeticus Ornatus; flowering in clusters; perfectly hardy with slight protection.

Elvira. Pure white, Bulbs Bulbs

With yellow cup; pop- $\$ 9.00 \$ 85.00$

Laurens Koster. Yellow, with golden cup .. $9.00 \quad 85.00$

\section{Narcissus Odorus (Jonquils)}

Deliciously sweet, bright rellow-flowered varieties. Very easily grown and should be planted in quantity for cutting.

Varcissus, Empress. Campernelle rugulosus. Large, rich yellow
flowers, borne very freely, and fine for cutting $\ldots \ldots \ldots \ldots \ldots \ldots \ldots \ldots \ldots \ldots \ldots \ldots \ldots . \$ 7.00 \$ \$ 60.00$

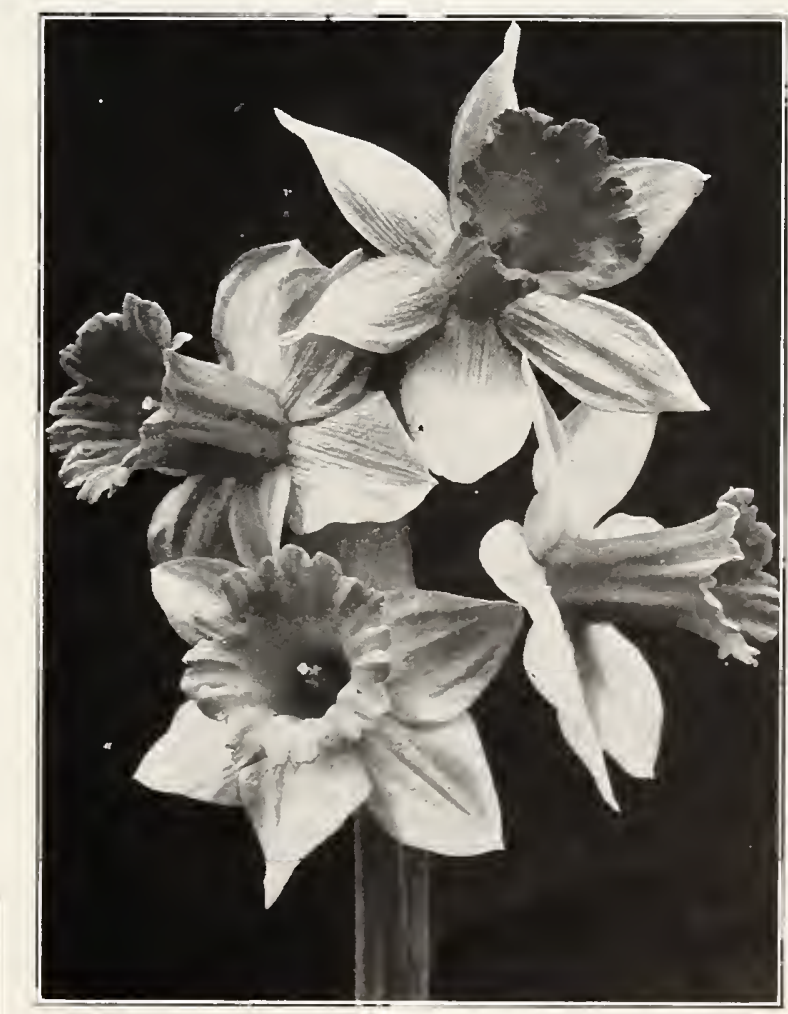

$100 \quad 1000$ $100 \quad 1000$ 


\section{Select Exhibition Hyacinths} BULBS MFASURE 20 CENTIMTTERS OR OVIR AND

These are varieties selected for their large sized spikes, elegance of form, and beauty and richness of color. The bulbs are of mammoth size-the cream of the crop-and naturally command advanced prices. We offer this grade only in limited quantities and request early orders for them. Exhibition Hyacinth bulbs are unsurpassed for them. Exhibition Hyacinth bulbs are unsurpassed for they are to grow in Hyacinth glasses: may be flowered in any large vase, if this is preferred to pot cuiture.

PRICE, AII BUIBS AS IISTED BEIOW : $\$ 2.00$ per 10; $\$ 16.00$ per 100 .

\section{ROSE}

Ia Victoire. Shiny carmine-rose, with large, well filled spikes. A splendid bedding variety.

Marconi. Bright deep rose: short, broad trusses, bolne on stiff stems. A good forcer and fine outdoors.

\section{IIGHT ROSE AND PINK}

Iady Dexby. Beautiful, clear rose-pink, with large, compact trusses. Farly; fine for both forcing and bedding. Pink perfection. Iight carmine-rose, with large, compact spikes. One of the best varieties in its class for pots. Queen of the Pinks. A very lovely pink; trusses broad and large, with good sized bells and strong stems.

\section{IIGIT BIUE AND IILAC}

Perle Brilliant, light blue, tinged lavender; splendid spikes with large, substantial bells. A fine pot Hyacinth and good for bedding.

Queen of the Blues. Clear, light porcelain blue; a strong growing variety with large, well formed trusses. One of the best of its color, particularly for bedding.

schotel. Clear porcelain blue; beautiful long spikes on strong stems. An excellent pot Hyacinth and the best light blue bedding variety.

\section{DARK BIUE}

Grand Maitre. Deep blue with long, compact spikes of large bells, on strong stems. One of the most popular blues; fille for pots as well as bedding.

King of the Blues. Dark violet-blue: splendid large for late forcing and bedding.

\section{PURE WHITE}

Arentine Arendzen. One of the finest whites; long spikes with large, snowy white bells. Elarly, fine for forcing and a good bedder.

La Grandesse. Pure white with fine, compact spikes. The best late forcing variety and fine for bedding as well

I'Innocence. This is the most satisfactory all-around pure white. Compact spikes with large bells. Does well indoors and out.

Queen of the whites. Pure white with long, well filled trusses of large, substantial bells. The finest white.

\section{YELIOW}

City of Elaarlem. The finest of the yellows. Well formed trusses of orange-yellow bells. An excellent variety for forcing and bedding.

\section{VIOLETT}

Sir Wm. Mangfield.

\section{Named Single Hyacinths}

We strongly recommend the use of Named Bedding Hyacinths for outdoor planting in preference to unnamed Hyacinths under color. The latter are made up of many varieties in mixture, which are not unlform in height, color, or time of blooming. When named bedding Hyaand time of blooming are insured and at a cost not much in excess of unnamed bedding Hyacinths. First size or exhibition size bulbs are too costly for bedding and flowers are too heavy, falling over from their own weight.

ROSE AND RED SHADES

Queen of the Pinks. Brignt, glistening pink; tall, erect. WHITE SFADES

L'Innocence, Pure white; large bells; fine spike. Queen of the whites. Pure white; early.

\section{BIUE SFADES}

Grand Maitre. Deep lavender-blue; immense, loose spike. King of the Blues. Rich dark blue; large, perfect spike. Perle Brillante. Light blue; large, erect.

\section{YEI.}

City of Eaarlem. Rich deep yellow; tall, erect spike. PRICE. $\$ 12.00$ per 100; $\$ 110.00$ per 1000

\section{Miniature or Dutch Roman Hyacinths}

Bulbs Measure 14-15 Centimeters.

These are the 3-year-old bulbs of the Dutch Hyacinths, easily forced ani largely grown for Winter flowering. Can be forced in pots, pans, or grown in bowls and vases in Holland Fiber. They bloom later than the true French Roman Hyacinths but produce larger spikes. Five to six bulbs can be potted in a 6-inch pot. Treatment same as for Dutch Hyacinths.

Miniature Hyacinths are splendid for forcing. They are distinguished from the ordinary Dutch Hyacinths by a looser flower spike and small, neat bells. The colors are delightful and when planted in low pots or pans, one color to a pan, the effect is light and graceful, and no more charming decoration could be found.

City of Haarlem. Yellow.

Grand Maitre. Lavender-blue.

ra Victoire. Carmine-rose.

I'Innocence. Pure white.

Queen of the Pinks. Deep rose-pink.

Schotel. Light blue.

PRICE, ABOVE VARIETIES:

\section{French Roman Hyacinths}

French Roman Hyacinths are among the earliest bulbs to be had in flower. The bulbs arrive from France late in August, and, like all bulbs grown in the south of France, they may be had in flower from November all through the Winter months, if potted up in september and at intervals of every two weeks. They are much prized for pots or cutting on acount of their graceful appearance and delicate fragrance. The bulbs are about the same size as the Miniature Dutch Hyacinths offered on this page, and may be planted six or seven to a 5-or 6-inch pot, or ten to twelve bulbs to an 8-or 9-inch bulb pan. The fowers are smaller than those of the Dutch Hyacinths, and are borne in great profusion, the Iarger bulbs frequently having three to five graceful spikes of bloom. The white variety is the most reliable. They are not hardy in our northern climate, and should not white. Mammoth bulbs, 12 to 15 ctms.... $\begin{gathered}\text { Bulbs } \\ \$ 12.00\end{gathered} \begin{gathered}\text { Bulhs } \\ \$ 110.00\end{gathered}$

\section{Wild Crocuses - Species for Rock Garden or Border}

Besides the Dutch Crocuses there are certain species that blossom very much earlier in the year, of ten before the snow has gone. The flowers of these wild sorts are smaller than those of the Dutch kinds, but they are as vigorous and free as the others. Given a sunny position in the rock garden, or a sheltered position in grass where the sun may encourage them freely, they will surprise you by their hardy appearance in the face of cold and storms.

WIID AUTUMN-FIOWERING SPECIES

For Rock Garden or Fardy Border. $100 \quad 1000$

Bulbs Bulbs to Kurdistan; large flowers, purplish lilac, feathered violet, with showy orange stigmata, slightly scented. Flowering freely

Speciosus. Bright rict-inue, prettily veined, having orange-red anthers, and lignt yellow throat, large. handsome and showy; and massing in borders or in rock work.

zonatus. Rose-lilac, yellow center and orange zone; ethereal in its lovely coloring .... 5.50

WILD SPRING-FToWERING SPECISS For Rock Garden or Hardy Border.

Imperati. Fine shade of mauve; exterior of Bulbs Bulbs

thert. Fine shace of mause; exterior of $\$ 10.00 \$ 90.00$ sieberi. A gem; lavender flowers with bright orange stigmata ................. Susianus. Most attractive, deep, rich yellow with dark rich brown flames on exterior.
Tommasinianus. Flower varies from a pale mauve to a rich purple .................

Versicolor. Strong grower, Howers are white 


\section{Crocuses}

\section{DUTCH VARIETIES}

Crocuses will grow in many positions-in the grass. in the flower burders, among shrubs, in the rock garden, in sun or shade, even under Beech trees. Perhaps the ideal position for them is one where they receive the sun but for part of the day. A position reaching out from beneath tall trees where the grass need not be mown until the pretty striped foliage is quite matured. In such a situation they will not be blanched by the too hot rays of the sun nor caught by the late frosts. They should be splashed upon the landscape with a broad brush-great irregular patches of the various Dutch varieties, one kind at a time, bit each planting blending with the next.

Dutch Spring-flowering varieties. Plant in the Fall. 100
Bulbs
1000
Bulbs Baron von Brunow. Large bluish mauve..\$2.00 $\$ 18.00$ King of the Whites. Large purple, white

... $2.50 \quad 20.00$

Mammoth Yellow .................. 2.50 20.00

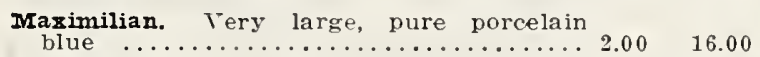

Mme. Mina. Very fine violet, striped ...2 $2.00 \quad 16.00$

Mont Blanc. Pure white ............ 2.00 16.00

Purpurea grandiflora. Very large; purple-

blue $\ldots \ldots \ldots \ldots \ldots \ldots \ldots \ldots \ldots \ldots . \ldots 2.50 \quad 20.00$

Sir Walter scott. White, striped lilac $\ldots 2.00 \quad 16.00$

Named
mixture $\ldots \ldots \ldots \ldots \ldots \ldots \ldots \ldots \ldots \ldots \ldots \ldots \ldots \ldots$

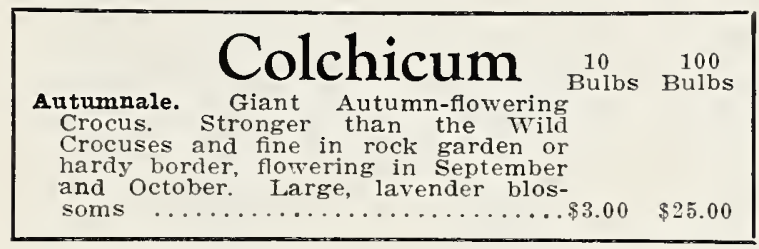

\section{Freesia}

This is one of the most beautiful of all Cape bulbs, possessing a peculiar grace of form, and its fragrance is most delightful, one pot of five or six bulbs being sufficient to perfume a whole house.

When planting Freesia bulbs in pots or pans, they may be spaced two inches apart and must be staked as they grow; if planted in benches they may be set four inches in rows two inches apart.

The soil should be a light sandy loam; old soil is the best in which some other crop has been grown during the previous season. This may be enriched with welldecayed stable or sheep manure. The best time to plant is septemer or sheep nanure. The best time to plant for the reason that the bulbs will not have had sufficient for t.

To produce the largest and finest flowers they should be grown cool; a day temperature of 60 degrees and night temperature of 45 to 50 degrees suits them best; they like plenty of water at all times and especially so i $\vec{r}$ they are subjected to high temperature.

California. Extra fine, bright golden yellow splendid cut flower ...............\$4.00 \$35.00

Carrie Budau. I.avender-pink; large ...... $4.50 \quad 40.00$

General Pershing. Extra good; large open flowers of a pinkish lavender with yellow lip, suffused bronze, produced on stems often 3 feet tall, with several side laterals:
strong grower; liberil producer. Selected

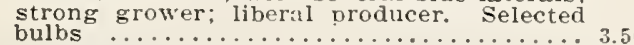

June Michelsen. Large, deep rose-pink, yellow blotch .................. 5.00

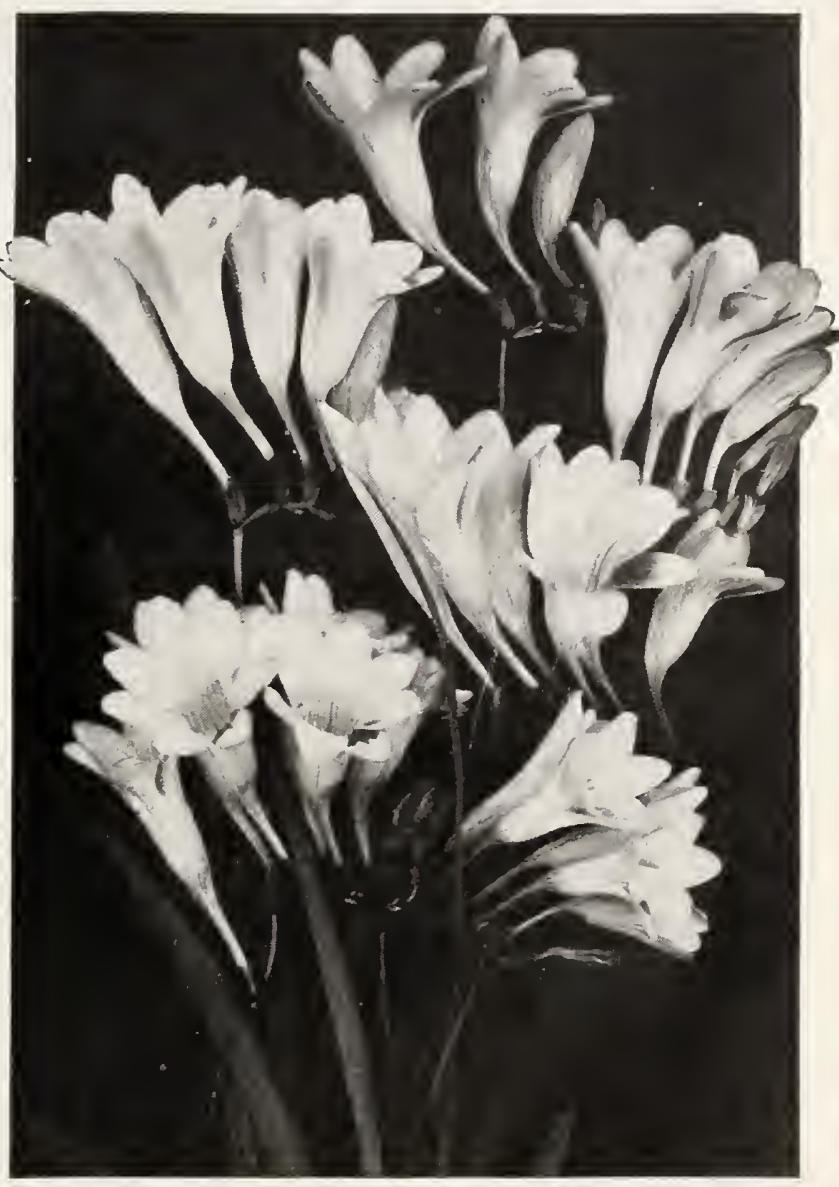

Freesias, General Pershing.

$\begin{array}{cc}100 & 1000 \\ \text { Bulbs Bulb }\end{array}$

Furity. A magnificent, snowy white; of very

large size and great length of stem. A
truss bearing from 8 to 10 buds, of which

six are often open at one time. Mammoth

bulbs, $50 \mathrm{c}$ per $10 \ldots \ldots \ldots \ldots \ldots \ldots \ldots \ldots+\ldots .00 \quad \$ 25.00$

Splendens. Very good violet shade; good grower with large flowers: Inighly recommended to grow in quantity ..........4.00

Yellow Prince. Light yellow, overlaid with silvery sheen; very tall, strong grower
with large, wide-open flowers; the buds have, upon opening, a gray appearance, but when finally open the flowers are of a beautiful $y \in l l o w$

\section{Rainbow Mixture of Freesias}

The new colored Freesias which have been introduced lately have been selected from thousands of seedings. Some of the seedlings not named are as fine as the named varieties. It is these better seedlings we offer. If you should live in that part of America where there is little or no frost during the winter, plant some of these bulbs outside and you will be surprised at the wonderful cut flowers these mized bulbs produce.

Per hundred, \$3.50.

Per thousand, $\$ 30.00$. 
$\begin{array}{lllllllllllllllllllllllllll}T H & H & W & A & Y & S & I & D & E & G & A & R & D & E & N & S & C & O\end{array}$

\section{Lilium Candidum}

(MADONNA IILY)

Choice Northern Grown. Arrive in August or September.

Maeterlinck refer's to this loveliest of Lilies when he says:

"The great white Lily, the old lord of the gardens, the only authentic prince among all tlie commonalts issuing from the kitchen-garden, the ditches, the copses, the pools and the moors, among the strangers come from none knows where, with his invariable six-petaled chalice of silver, whose nobility dates back to that of the gods themselves, the immemorial Lily raises his ancient sceptre, august, inviolate, which creates around it a zone of chastity, silence and light.'

Be very careful that you plant the right type of this beautiful Lily in your garden. There is an earlyflowering variety which is grown in the south of France. These should not be used in America; if planted in the garden, they are prone to disease and are unsatisfactory. In Europe this type is called L. candidum speciosum. This variety is only too often sold because they cost less.

The true type to use for the garden is the L. candidurn from the north of France. This bulb is easily recognized by its white, fleshy scales, by those that know both types.

This Lily of all Lilies should be planted in quantity in every garden-emblem of purity, the inspiration of poet and painter for centuries, and a benediction in the garden whell June is melting into July-their delicious fragrance is not equalled by any other Lily.

Plant in loam or sandy soil, surrounding the bulb with sharp sand and placing it somewhat on its side. An open, fully exposed place is best for it. After it has become fully established leave it alone as it much resents disturbance at the roots. If necessary to transplant, do so as soon as the flower stems die down.

SELECTED BULBS
MAMMOTH

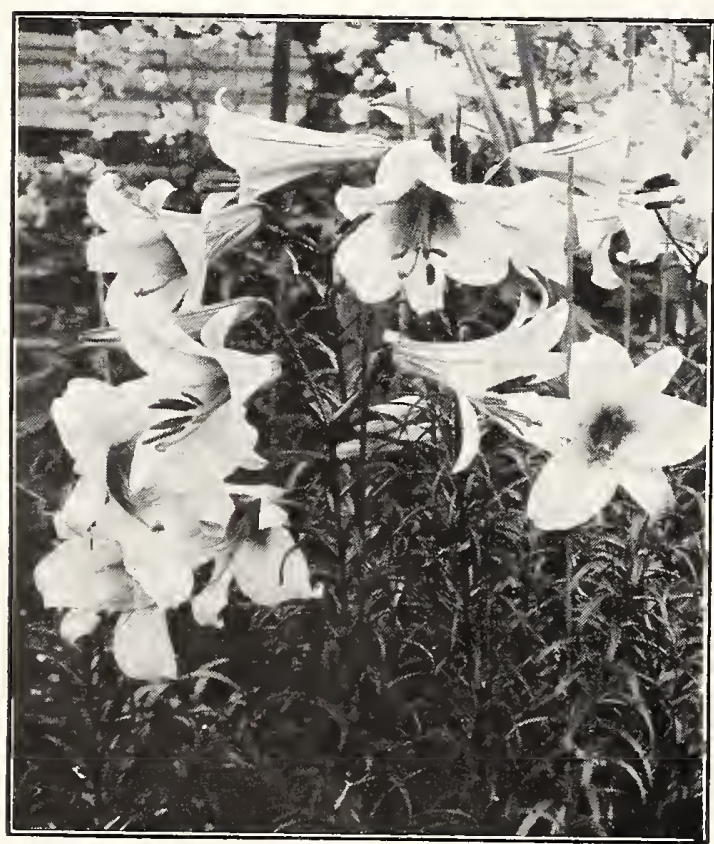

Lilium Regale or Myriophyllum-Regal Lily.

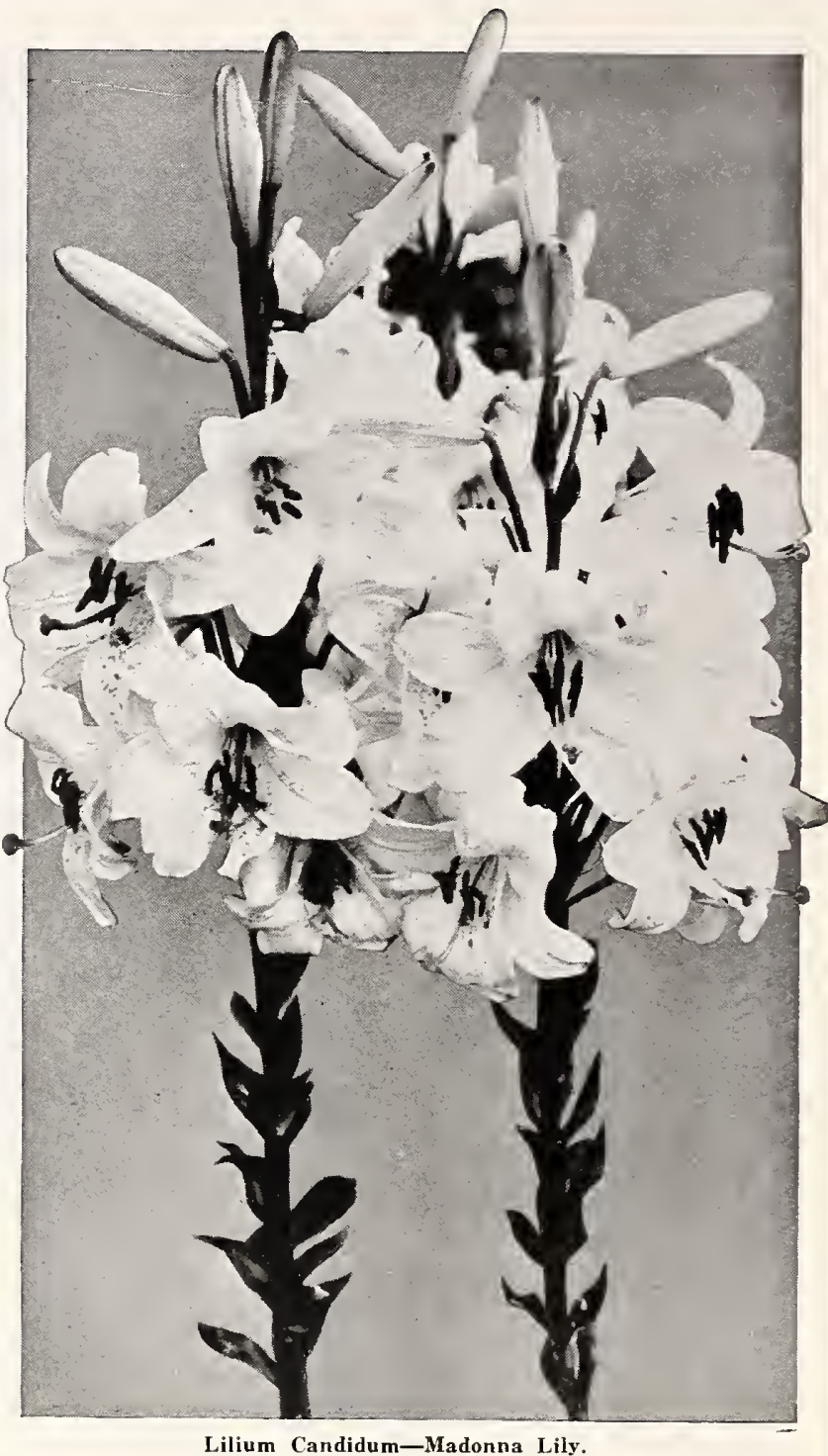

Lilium Candidum-Madonna Lily.

\section{Lilium Regale or Myriophyllum}

It is absolutely hardy, and is excellent for forcing. It has been predicted that this will become the Easter Lily of the future, and being so hardy, may be grown at home. The flowers are white, slightly suffused with pink, with a beautiful shade of canary-yellow at the center, and extending part way up the trumpet. It is delightfully perfumed, reminding one of the Jasmine, and lacking the heavy, oppressive odor of most Lilies. Blooms out-of-doors early in July. (Bulbs ready late October).

STRONG BULBS

$10 \quad 100$ Bulbs Bulbs $\$ 4.00 \$ 35.00$

SELECTED BUIBS

$6.00 \quad 50.00$

We are the largest growers of this Lily in the country, producing it by the thousands.

For other Lilies, see pages 30 and 31 , or write for our Hardy Plant Catalog, which contains a complete list. 


\section{Miscellaneous Bulbs and Roots for Fall or Early Spring Planting for Permanent Effects in Borders, Rock Gardens or Indoors}

For planting in accord with the natural surroundings of your gardens, expressive of perfect harmony and good taste; along the woodland path, in wild fiover sanctuaries, along brooks or ponds, or wherever naturalistic planting is wanted. For planting of banks or ground cover amongst Daffodils, Hyacinths or Tulips; in the border in drifts or as edging for flowerbeds.

\section{Amaryllis Hippeastrum

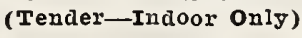

$100 \quad 1000$

Giant American Hybrid. There is nothing that will give the amateur greater pleasure for the window garden than these giantflowering Amaryllis that are so easily managed. The strain we offer is the finest that has ever been produced in this country, strong bulbs throwing vigorous stems with from four to six gigantic blooms of the most perfect form, ranging in color from pure white grounds with varied markings of rose, red and crimson to the richest self colors as scarlet, crimson, bright supply either in mixture of light shades or supply either in mixture of light shades or

in dark shades. Large, strong hulbs, toc $\$ 5.50 \quad \$ 50.00$

\section{Anemone}

(Balf Hardy-Must Have Protection) $100 \quad 1000$

St. Brigid Finest Irish strain, showing a

\section{Calla Lilies}

\section{(Tender-Indoor Only)}

These like a stiff, clayey soil with a small quantity of shredded cow manure. Bulbs should be set with the crown, or top, protruding just above the surface. When in growing condition, warm water given several times during the week will hasten the flowering period and increase the number of blooms. When using the large sized bulbs, plant but one in a pot: smaller ones, two. We call especial attention to the Yellow Calla, which is one of the grandest varieties in cultivation, and most valuable for house or conservatory decoration. See the description below. Plant Callas indoors only in the Fall or Spring of the year. 10 100 White Calla Iily.

Bulbs Bulb

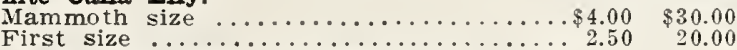

Yellow Calla inily A grand norelty-one

that should be planted extensively. The

deep golden yellow flowers are truly mag-

nificent and produced in abundance. The

green foliage is spotted creamy white,

which adds to its beauty.

Mammoth size

First size

\section{Camassia} (Hardy) Perfectly hardy bulbous plants that thoive well in any Gulbs Bulbs Esculenta. A purple form, rich in color Grows 2 feet high. Very showy in masses. Leichtlini (Sky-blue). Grows 3 feet lish,
with as many as one hundred flowers, of the finest form, star-shaped and about $1 \frac{1}{2}$ inches across, flowering in long succession

\section{Brodiaeas}

\section{(Hardy)}

These plants have a small bulb, producing grassy leaves near the ground, and very slender, but stiff, naked stems bearing a head of waxy flowers of great lasting quality. All are pretty. Their culture is the same as for Narcissi, and just as easy as for that flower. They are easily naturalized in almost any soil. Plant them about 3 inches deep, and leave them alone. They are especially happy under oak and deciduous trees, in crevices in rocks, or in rough, gritty soils.

Coccinea (Floral Firecracker). The stems rise to 2 feet, while the flowers are a vivid crimson tipped with pea-green. The resemblance to a bunch of firecrackers catches the eye at once. A group of these bulbs in a mass of felns or light-foliaged plants is striking, and they do very well potted $\begin{array}{lr}\text { Crocea. Has light yellow flowers in umbels. } \begin{array}{c}100 \\ \$ 7.00\end{array} & 1000 \\ \text { Bulbs } & \$ 60.00 \\ \text { Grandiflora. Has a few large, glossy purple } & \end{array}$

flowers of much beauty and great lasting

dualities. The bulbs can be naturalized in

any clay soil, especially if moist .......

Hendersoni. Bears many flowers in an um-

bel. The ground color is light with a deep

Lactea. Has a close umbel of milky white

flowers

Laxa. Is known as Blue Milla, and has

many-flowered umbel of fine blue flowers.

It is one of the best for naturalizing...

\section{Chionodoxa}

(Hardy)

$100-1000$

Bulbs Bulbs

Iuciliae (Glory of the Snow). A mass plant ing forms one of the most sumptous displays of floral beauty. a mass of blue and white intense and brilliant. They bloom at the time of the Crocuses, producing dwarf flower spikes, bearing from 12 to 15 flowers of a sky-blue with a pure white heart, creating a lovely effect. They should be planted in the Fall, three inches in a sunny location or in half shade and in places where they can remain undisturbed for a number of years. The flowers will cross with one another and will seed themselves, forming natural colonies .....

Sardensis. This is the earlier of the cwo varieties to come into bloom, and the first real blue flower of another year. This is a rich, blue self-color. The remarks made for the variety Lucilliae apply to Sarfor the variety Lucilliae apply to Sar-

\section{Eranthis}

(Hardy-Give Slight Protection)

$100 \quad 1000$

Hyemalis (Winter Aconite). These produce at about the same time that the crocuses are in bloom, little yellow flowers like Buttercups about three inches above the ground, with settings of fine green, frilledlike collars which never seen to They thill thrive under trees where few other plants can hold their own. They seed themselves freely and colonies from self-sown seed are soon formed. Plant firmly two inches are soon formed. Plant firmly two inches deep, in shade or half shade, about 18
bulbs to a square foot $\ldots \ldots \ldots \ldots \ldots \ldots \ldots 2.25 \quad \$ 18.00$

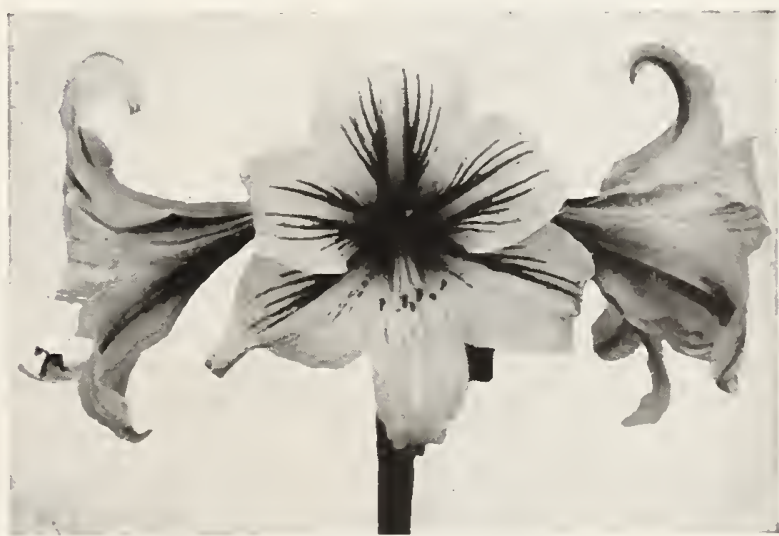

Amaryllis Hippeastrum. 


\section{Fritillaria (Mission Bells)} FUROPEAN VARIETIES

\section{(Fardy)}

$10 \quad 100$

Imperialis (Crown Imperial). One of the most characteristic plants of old-fashioned gardens. It is the most robust of all the
species. The flowers are borne in umbels on stout stens 3 to 4 feet high.

Meleagris (Guinea Hen Flower or checkered Lily). These produce in early April, dwarf, pendent, bell-shaped flowers in various shades of color, curiously checkered. striped and splashed. They are very erfective in colonies, requiring a somewhat dry situation. Invaluable for mass plant ing in the meadows and for naturalizing. \$4.00 $\$ 35.00$

\section{Galanthus (Baray) $\underset{100}{(S n d r o p s)}$}

These are particularly effective under

hedges, under cedar trees and in thin woodland. They are the first to open in the Spring and are very lovely. They dislike being moved and should be left alone to naturalize themselves. Plant two inches deep; mulch in Winter with straw, hay, leaves or well-decayed manure. The single-flowering snowdrops, if they are left alone, soon take to producing double flowers. The differences and variations in the varieties of Snowdrops are so comparatively small that it does not seem worth while to offer them in variety .... \$3.00 \$25.00

\section{Spanish Iris (Jris Hispanica) \\ (Falf Fardy-Give Protection)}

These beautiful bulbous Iris have appropriately beer called the "Orchids of the Hardy Flower Garden" For best effects they should be planted in beds or groups of twenty-five or more, the larger the number the finer the effect. They grow from 18 to 21 inches high, and bloom from the end of May on through June. $100 \quad 1000$ Cajanus. Fine golden yellow .......... Bulbs $\$$ Bulbs Flora. White and light lilac King of the Blues. Fine, clear blue ....... 4.50 40.00 Oueen wilhelmina. Large, pure white .... 4.50 40.00 Beconnaissance. Beautiful bronze, very large flower: the finest of all bronze colored Iris. 4.50 40.00

\section{Ixias}

( Ealf Hardy-Give Protection)

Desirable bulbs for forcing or outside borders. If planted outside they require covering during the Winter.

Choice Mixed Colors $\begin{array}{ll}100 & 1000 \\ \text { Bulbs } & \text { Bulbs } \\ \$ 2.50 & \$ 20.00\end{array}$

\section{Leucojum}

$$
\text { (Fardy) }
$$

$100 \quad 1000$ Bulbs Bulbs

Vernum (Spring Snowflake). This is one of the earliest and most attractive spring they bear dainty nodding flowers which are white, tipped with green. They should be planted in early Fall in a good, light. wel or 5 inches apart in masses or bold clumps. to be effective, 2 inches deep, and then be to be effective, 2 inches deep, and then be
left alone to bloom year after year $\ldots \ldots . \$ 5.00$

\section{Ranunculus}

(Half Hardy-Must Have Protection)

Double flowers on strong, straight stems 8 to 12 inches long. The colors range in a large diversified assortment Excellent for forcing. 100 1000

Double French Mixed. Strong roots ......\$4.00 $\$ 35.00$

\section{Muscari (Grape Hyacinths)} (Hardy)

$100 \quad 1000$

Botryoides coeruleum. Bright blue; very free grower which naturalizes easily, $\$ 2.00 \quad \$ 17.50$

Botryoides album. This is the white form which is very pretty planted with the blue

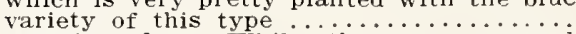
Heavenly Blue. While there are several

kinds of Muscari, we consider this variety the best for mass planting. Their flowers open just about the time that the Chionodoxas and crocuses are going off. They do very well in the wild garden and also in the grass if it is not too rank. They are nice under trees and along the borders where they may be left undisturbed. They will seed themselves ablished .............

\section{Scillas (Squills)}

\section{(}

These flourish in sun as well as in shade under trees. They are not particular about the soil in which they grow They are ideal for the wild garden but they are not to be lespised in the border, especially if they are left alone for two or three years without being disturbed in any way. They are splendid in the rock garden. Pro$\begin{array}{lll}\text { duce drooping bell-like flowers. } & 100 & 1000 \\ \text { Bulbs Bulbs }\end{array}$

Bifolia. Dwarf, rich blue flowers, which bloom with the Winter Aconite in March. Excellent for clumps, edgings and rock-

work ......................... \$3.25 \$29.00

Campanulata Blue. Porcelain blue, candelabra-shaped bells, blooming with the May-
flowering Tulips. Plant four inches deep.. 2.50 23.00 Campanulata rosea. This is a soft lilac-rose form of this type $\ldots \ldots \ldots \ldots \ldots \ldots \ldots . . .3 .25 \quad 30.00$

Nutans. The True English Blue Bell. Shepherd's crook-shaped flowers; very showy and vigorous; very effective planted with the May-flowering Tulips. plant four the May-flowering Tulips. Plant four Mulch in Autumn with leaf-soil, leaves or Mulch in Autumn with leaf-soil, leaves or

peruviana. Very good for indoor culture make bold spikes resembling the Hyacinth good in rock gardens with slight protection during the winter.... 15.00

Sibirica Blue (The Siberian Squili). This is the earliest to flower, connecting the Fallflowering of the Crocuses with that of the Narcissi. They are fine for naturalizing under trees or in open woodland, producing drooping, bell-like flowers on stems 3 to 4 inches in height. Succeed very well in the rock garden. Color bright blue Plant three inches deep in shade, half Plant three inches deep in shade, half 3.00

27.50

PLANTING. The table below shows the number of plants or bulbs required to fill a circular bed of the dimensions given. In planting begin at outside row-where 6 inches apart, 3 inches from edge of bed; where 12 inches somewhat eloser together in the two outer rows, giving more space between each plant or bulb toward the center of the bed.

\begin{tabular}{|c|c|c|c|c|c|c|c|c|c|c|c|}
\hline $\begin{array}{c}\text { Diameter of } \\
\text { bed }\end{array}$ & $\begin{array}{l}6 \text { in. } \\
\text { apart }\end{array}$ & $\begin{array}{l}12 \text { in. } \\
\text { apart }\end{array}$ & $\begin{array}{l}18 \text { in. } \\
\text { apart }\end{array}$ & $\begin{array}{l}24 \text { in. } \\
\text { apart }\end{array}$ & $\begin{array}{l}30 \text { in. } \\
\text { apart }\end{array}$ & $\begin{array}{c}\text { Diameter of } \\
\text { bed }\end{array}$ & $\begin{array}{l}6 \text { in. } \\
\text { apart }\end{array}$ & $\begin{array}{l}12 \text { in. } \\
\text { apart }\end{array}$ & $\begin{array}{l}18 \text { in. } \\
\text { apart }\end{array}$ & $\begin{array}{l}24 \text { in. } \\
\text { apart }\end{array}$ & $\begin{array}{l}30 \text { in. } \\
\text { apart }\end{array}$ \\
\hline 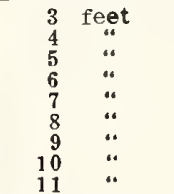 & $\begin{array}{r}28 \\
48 \\
80 \\
112 \\
152 \\
200 \\
256 \\
320 \\
380\end{array}$ & $\begin{array}{r}7 \\
12 \\
20 \\
28 \\
38 \\
5 n \\
64 \\
80 \\
95\end{array}$ & $\begin{array}{r}6 \\
8 \\
13 \\
17 \\
23 \\
28 \\
36 \\
42\end{array}$ & $\begin{array}{r}7 \\
9 \\
12 \\
16 \\
20 \\
24\end{array}$ & $\begin{array}{l}13 \\
16\end{array}$ & 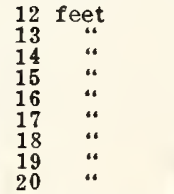 & $\begin{array}{r}452 \\
528 \\
612 \\
704 \\
804 \\
904 \\
1016 \\
1132 \\
1256\end{array}$ & $\begin{array}{l}113 \\
132 \\
153 \\
176 \\
201 \\
226 \\
254 \\
283 \\
314\end{array}$ & $\begin{array}{r}50 \\
59 \\
68 \\
78 \\
89 \\
100 \\
113 \\
126 \\
139\end{array}$ & $\begin{array}{l}28 \\
33 \\
39 \\
44 \\
50 \\
57 \\
63 \\
71 \\
78\end{array}$ & $\begin{array}{l}18 \\
22 \\
25 \\
28 \\
32 \\
36 \\
43 \\
46 \\
50\end{array}$ \\
\hline
\end{tabular}

A square bed will take ahout the same number of plants. For an oval bed, add length and breadth and divide by two. For example, an oval 9 feet long by 7 feet wide will require the same number of plants as a circular bed 8 feet in diameter. 


\section{ORDER SHEET}

\section{The Wayside Gardens Company Stop 67 \\ Mentor, Ohio}

Ship to (Name)

Street or

R. F. D. No.

Town or

City

County

Charge to
Date

Ship by

(State whether by Freight, Expres or Mall.)

Money Order Enclosed for \$

State

Cheque Enclosed for - $\$$

Address

May we substitute an equally good variety if any of the kinds ordered are sold out? No___ Yes

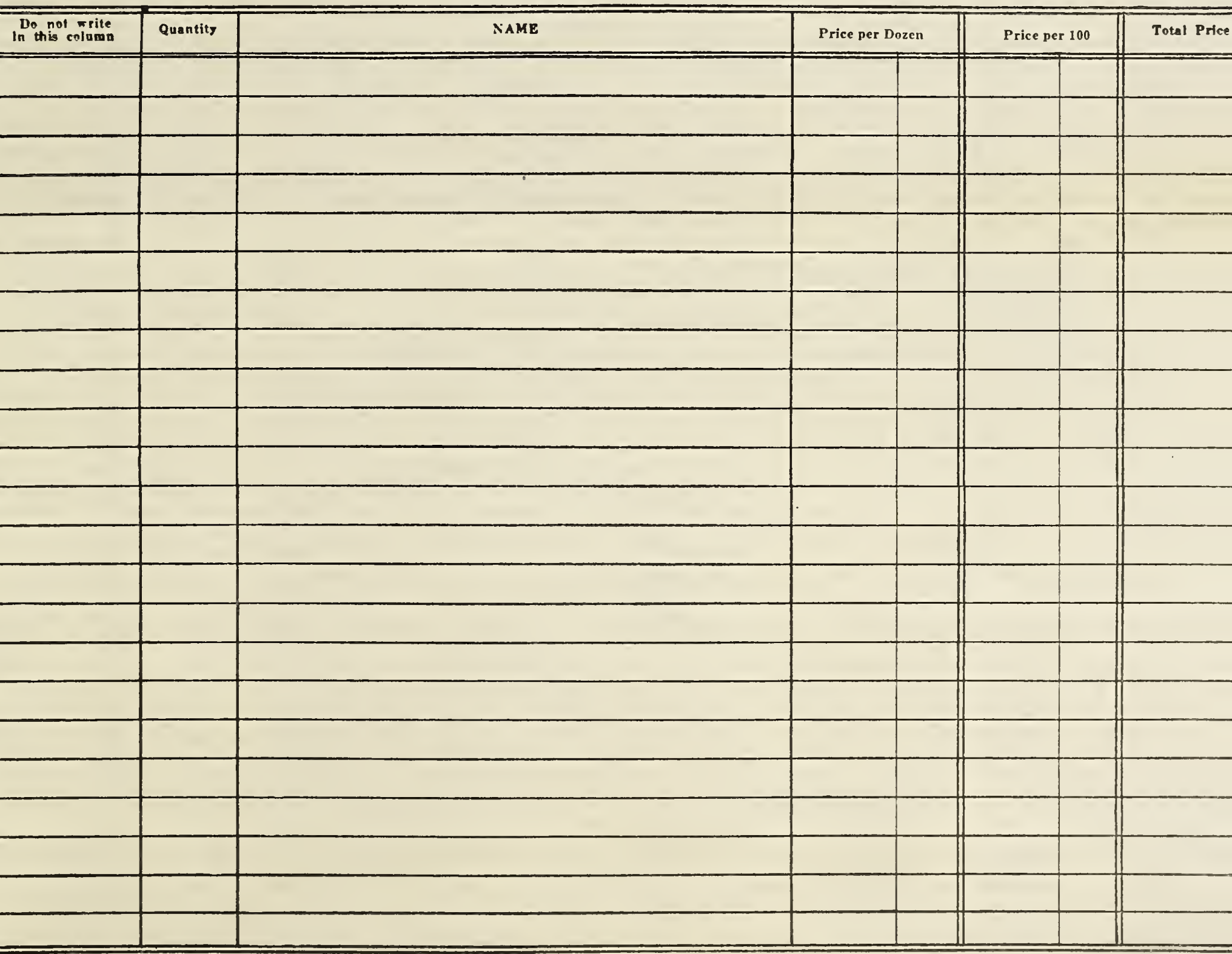

25 plants of a kind sold at 100 rate; 6 plants of a kind at dozen rate. Not less than 3 plants of a kind sold except where noted. 


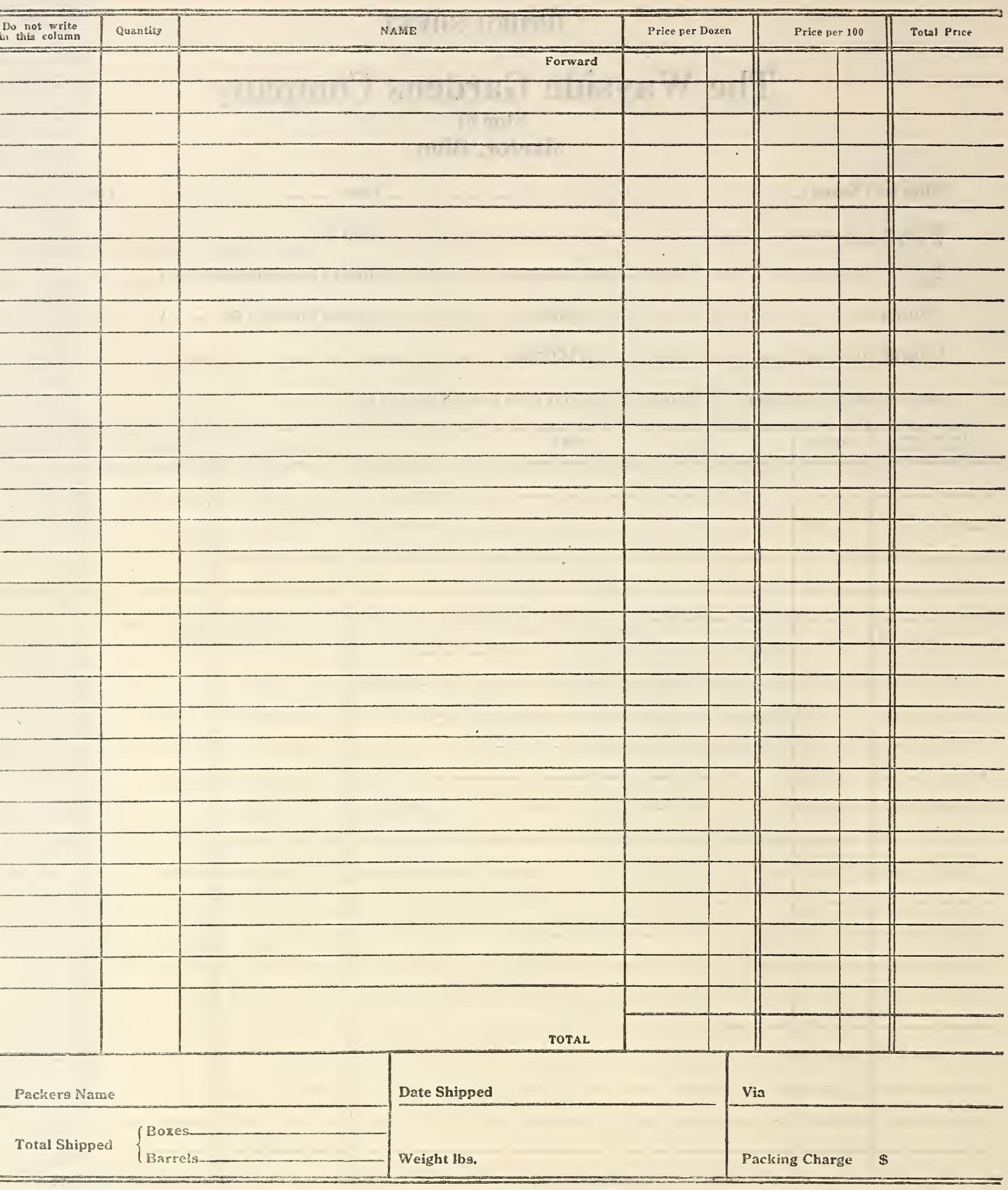




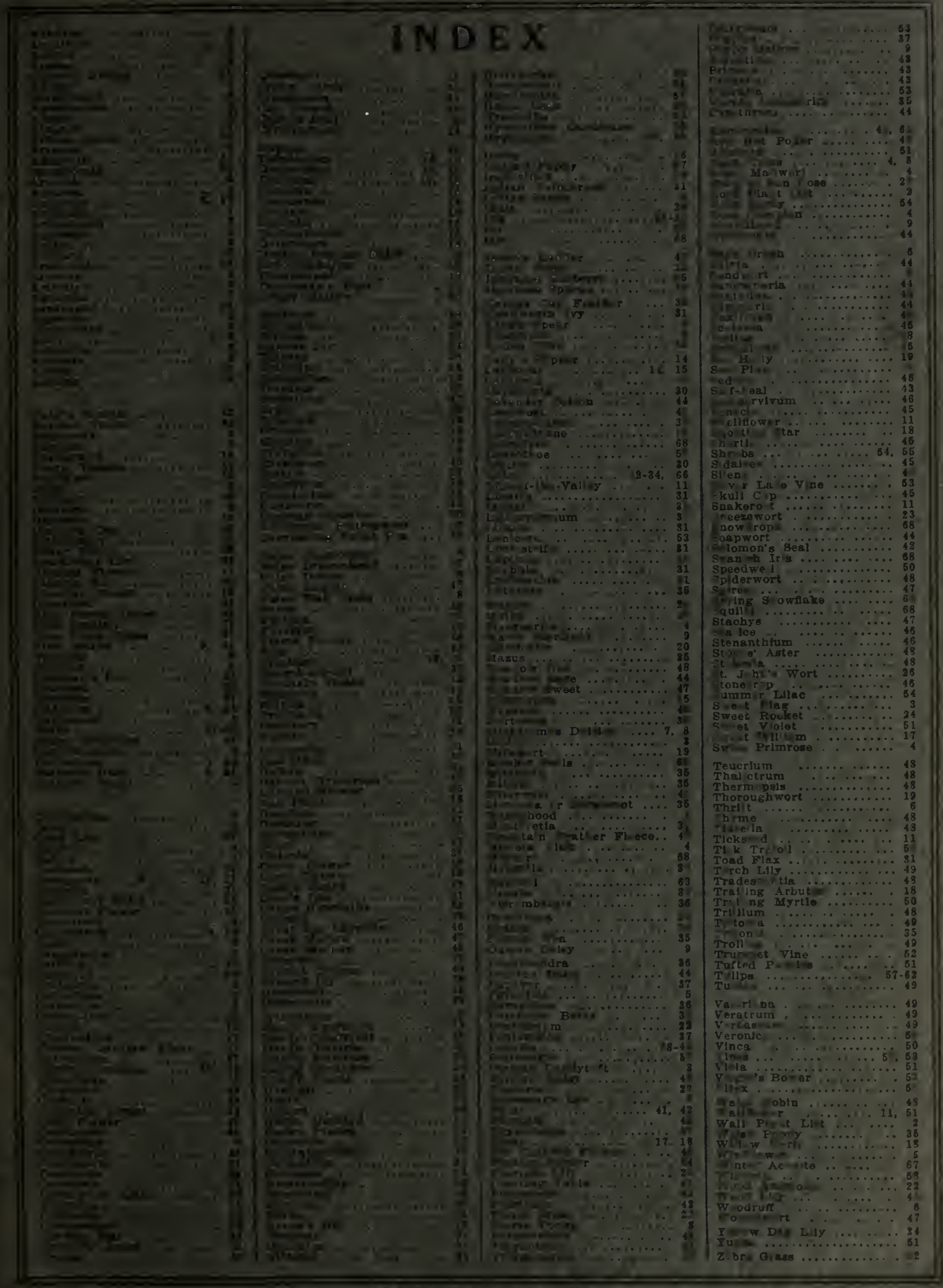




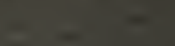

